\title{
Quality of Water from Crystalline Rock Aquifers in New England, New Jersey, and New York, 1995-2007
}

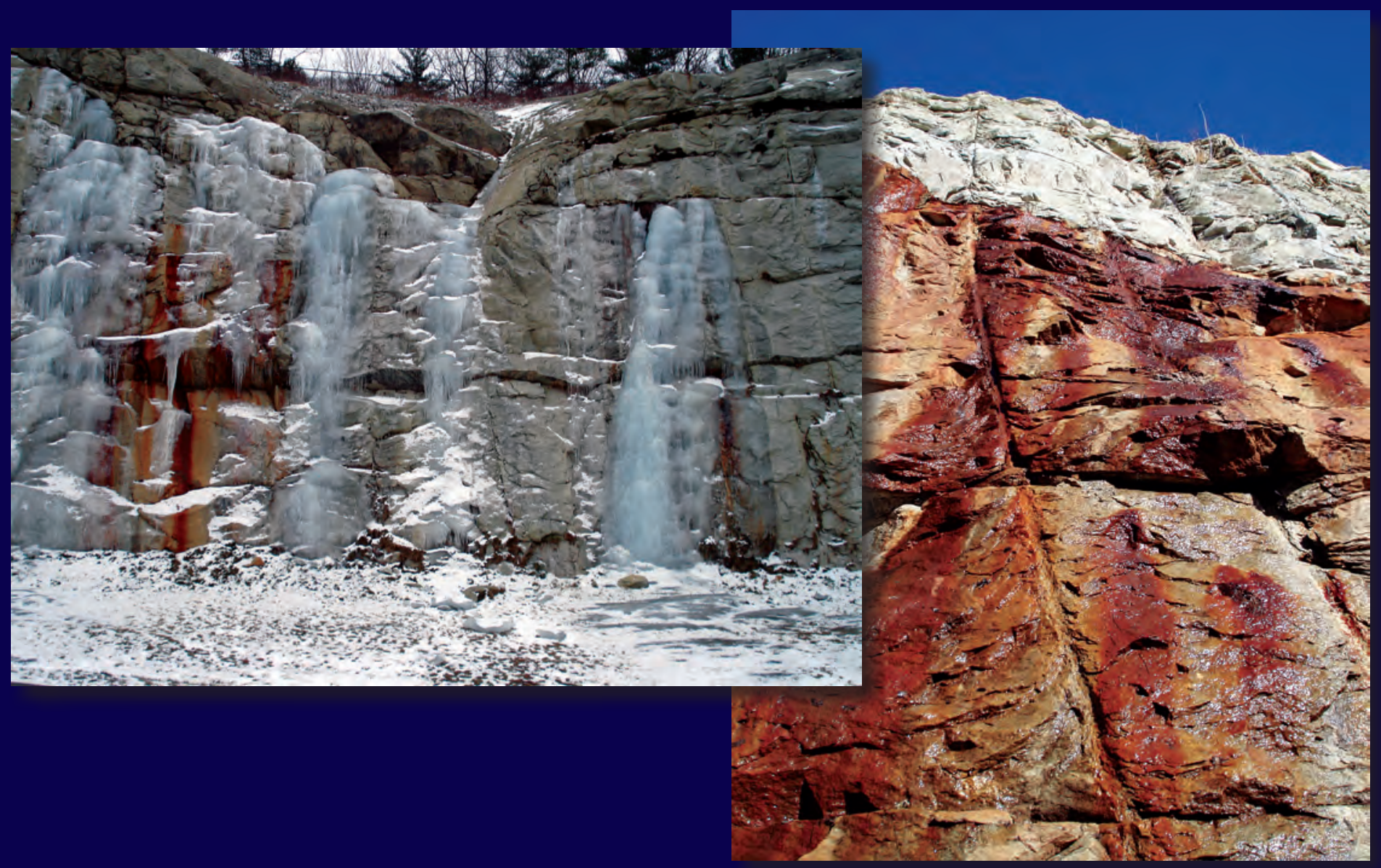

Scientific Investigations Report 2011-5220

Version 1.1, March 2018 
Cover. Photographs show a bedrock outcrop near the intersection of Post Road and Daniel Webster Highway (New Hampshire State Route 3) in Hooksett, New Hampshire. During the winter (left), groundwater flows out of the open fractures and forms a frozen waterfall over the exposed bedrock. During the summer (right), groundwater stains the exposed bedrock with precipitated iron oxides. 


\section{Quality of Water From Crystalline Rock Aquifers in New England, New Jersey, and New York, 1995-2007}

By Sarah M. Flanagan, Joseph D. Ayotte, and Gilpin R. Robinson, Jr.

National Water-Quality Assessment Program

Scientific Investigations Report 2011-5220

Version 1.1, March 2018 


\title{
U.S. Department of the Interior \\ RYAN K. ZINKE, Secretary
}

\section{U.S. Geological Survey William H. Werkheiser, Deputy Director exercizing the authority of the Director}

\author{
U.S. Geological Survey, Reston, Virginia: \\ First release: 2012 \\ Revised: March 2018 (ver 1.1)
}

\begin{abstract}
For more information on the USGS - the Federal source for science about the Earth, its natural and living resources, natural hazards, and the environment-visit https://www.usgs.gov or call 1-888-ASK-USGS.

For an overview of USGS information products, including maps, imagery, and publications, visit https://store.usgs.gov.
\end{abstract}

\footnotetext{
Any use of trade, product, or firm names is for descriptive purposes only and does not imply endorsement by the U.S. Government.

Although this report is in the public domain, permission must be secured from the individual copyright owners to reproduce any copyrighted materials contained within this report.
}

Suggested citation:

Flanagan, S.M., Ayotte, J.D., and Robinson, G.R., Jr., 2018, Quality of water from crystalline rock aquifers in New England, New Jersey, and New York, 1995-2007 (ver. 1.1, April 2018): U.S. Geological Survey Scientific Investigations Report 2011-5220, 104 p., https://doi.org/10.3133/sir20115220.

ISSN 2328-031X (print)

ISSN 2328-0328 (online)

ISBN 978-1-411-33417-5 


\section{Foreword}

The U.S. Geological Survey (USGS) is committed to providing the Nation with reliable scientific information that helps to enhance and protect the overall quality of life and that facilitates effective management of water, biological, energy, and mineral resources (http://www.usgs.gov/). Information on the Nation's water resources is critical to ensuring long-term availability of water that is safe for drinking and recreation and is suitable for industry, irrigation, and fish and wildlife. Population growth and increasing demands for water make the availability of that water, measured in terms of quantity and quality, even more essential to the long-term sustainability of our communities and ecosystems.

The USGS implemented the National Water-Quality Assessment (NAWQA) Program in 1991 to support national, regional, State, and local information needs and decisions related to water-quality management and policy (http://water.usgs.gov/nawqa). The NAWQA Program is designed to answer: What is the quality of our Nation's streams and groundwater? How are conditions changing over time? How do natural features and human activities affect the quality of streams and groundwater, and where are those effects most pronounced? By combining information on water chemistry, physical characteristics, stream habitat, and aquatic life, the NAWQA Program aims to provide sciencebased insights for current and emerging water issues and priorities. From 1991 to 2001, the NAWQA Program completed interdisciplinary assessments and established a baseline understanding of water-quality conditions in 51 of the Nation's river basins and aquifers, referred to as Study Units (http://water.usgs.gov/nawqa/studies/study_units.html).

In the second decade of the Program (2001-2012), a major focus is on regional assessments of water-quality conditions and trends. These regional assessments are based on major river basins and principal aquifers, which encompass larger regions of the country than the Study Units. Regional assessments extend the findings in the Study Units by filling critical gaps in characterizing the quality of surface water and groundwater, and by determining water-quality status and trends at sites that have been consistently monitored for more than a decade. In addition, the regional assessments continue to build an understanding of how natural features and human activities affect water quality. Many of the regional assessments employ modeling and other scientific tools, developed on the basis of data collected at individual sites, to help extend knowledge of water quality to unmonitored, yet comparable areas within the regions. The models thereby enhance the value of our existing data and our understanding of the hydrologic system. In addition, the models are useful in evaluating various resource-management scenarios and in predicting how our actions, such as reducing or managing nonpoint and point sources of contamination, land conversion, and altering flow and (or) pumping regimes, are likely to affect water conditions within a region.

Other activities planned during the second decade include continuing national syntheses of information on pesticides, volatile organic compounds (VOCs), nutrients, trace elements, and aquatic ecology; and continuing national topical studies on the fate of agricultural chemicals, effects of urbanization on stream ecosystems, bioaccumulation of mercury in stream ecosystems, effects of nutrient enrichment on stream ecosystems, and transport of contaminants to public-supply wells.

The USGS aims to disseminate credible, timely, and relevant science information to address practical and effective water-resource management and strategies that protect and restore water quality. We hope this NAWQA publication will provide you with insights and information to meet your needs, and will foster increased citizen awareness and involvement in the protection and restoration of our Nation's waters.

The USGS recognizes that a national assessment by a single program cannot address all waterresource issues of interest. External coordination at all levels is critical for cost-effective management, regulation, and conservation of our Nation's water resources. The NAWQA Program, therefore, depends on advice and information from other agencies-Federal, State, regional, interstate, Tribal, and local—as well as nongovernmental organizations, industry, academia, and other stakeholder groups. Your assistance and suggestions are greatly appreciated.

William H. Werkheiser

USGS Associate Director for Water 



\section{Acknowledgments}

The authors thank personnel of the six New England States Drinking Water Programs and Departments of Health that contributed U.S. Environmental Protection Agency Safe Drinking Water Act (SDWA) Program datasets and answered questions about the datasets throughout the analysis stage of this report: Tim Pricer, Vermont Drinking Water program; Elizabeth Hunt, Vermont Water Supply Division; Richard Amiralt, Rhode Island Department of Health, Office of Drinking Water Quality; Andrews L. Tolman, Maine Drinking Water Program; Damon Guterman, Massachusetts Department of Environmental Protection, Drinking Water Program; Darrell Smith and Thomas E. Reed, Connecticut Department of Public Health, Drinking Water Section; and Laurie Cullerot, Gail Daily, and Selina Makofsky, New Hampshire Drinking Water Program.

In addition, Marilee Horn, water use specialist in the U.S. Geological Survey New Hampshire/ Vermont Water Science Center, provided critical information for determining which SDWA water-system wells are completed in bedrock and which SDWA wells are completed in glacial aquifers in the States of Connecticut, New Hampshire, Rhode Island, and Vermont. Leon Kauffman and Zoltan Szabo, USGS, provided additional background information on the 29 NAWQA domestic wells in New Jersey and New York, which aided greatly in the interpretation of the water-quality data for this network. We wish to thank Alice Koller for the preliminary editorial review of the manuscript and Ruth Larkins, USGS, for the final editorial review of the manuscript, and Leslie A. DeSimone and Charles W. Schalk, USGS, for their peer reviews of this manuscript. 



\section{Contents}

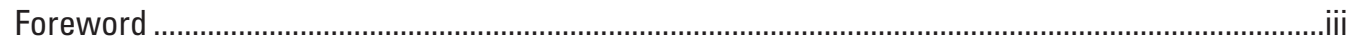

Acknowledgments

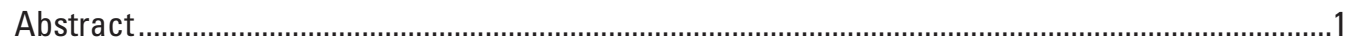

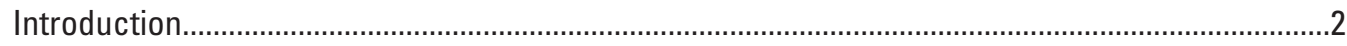

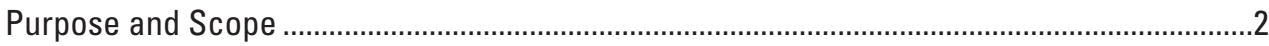

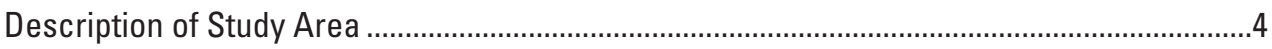

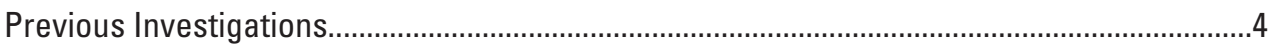

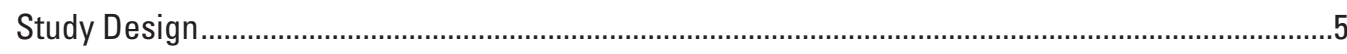

Data from USGS NAWQA Domestic Wells ..........................................................................

Quality Assurance and Quality Control of USGS NAWQA Samples...................................

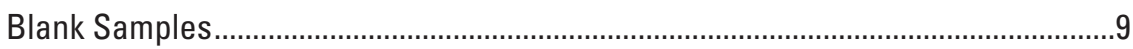

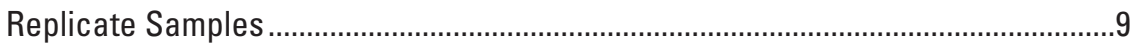

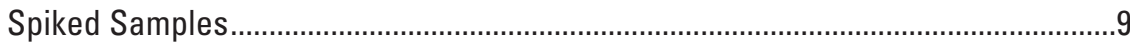

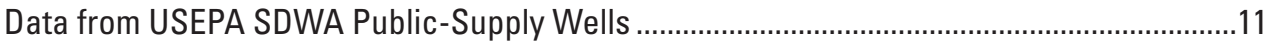

Treatment and Statistical Analysis of Water-Quality Data .......................................................12

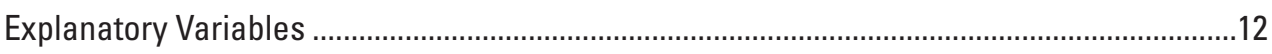

Categories of Land Use and Land Cover ..................................................................13

Categories of Population Density ............................................................................15

Categories of Well Depth and Casing Length ..............................................................15

Major Lithology Categories and Lithology Groups .......................................................16

Quality of Water in New England Crystalline Rock Aquifers........................................................19

Dissolved Gases and Apparent Age of Groundwater.........................................................19

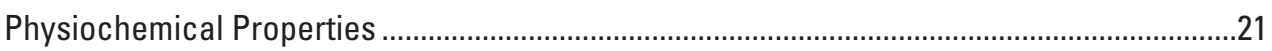

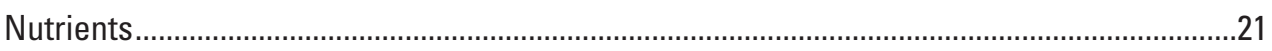

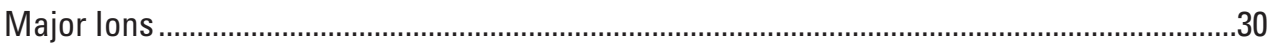

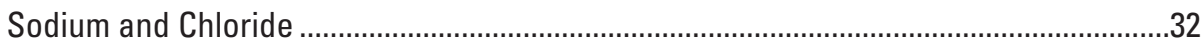

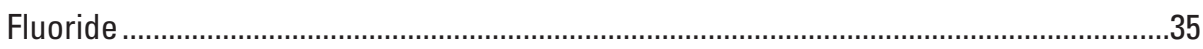

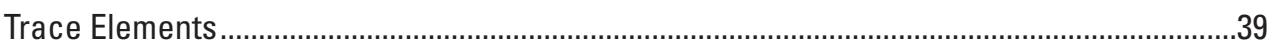

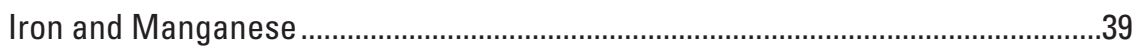

Aluminum, Barium, and Strontium ............................................................................

Boron, Lithium, and Molybdenum ...........................................................................4

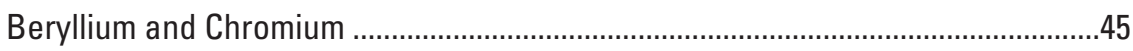

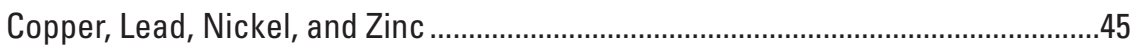

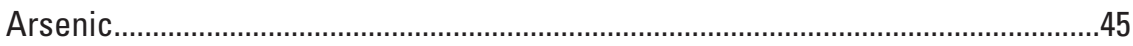

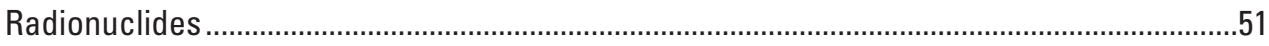

Gross Alpha- and Gross Beta-Particle Activity ………................................................51

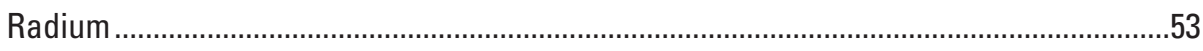

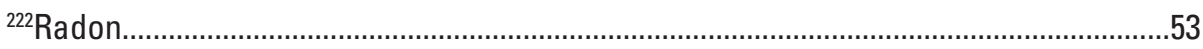

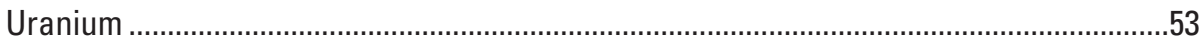

Co-occurrence of Selected Radionuclides and Lead...................................................60

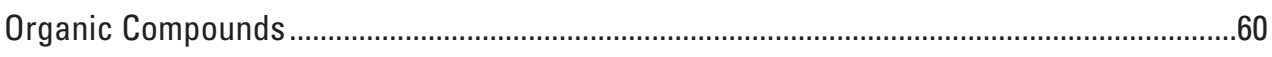

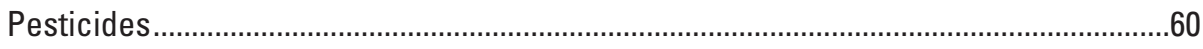

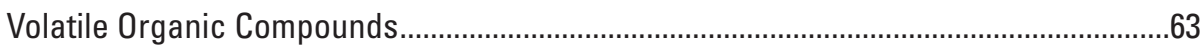


Methyl tert-Butyl Ether ........................................................................................66

Temporal Variability of Selected Water-Quality Constituents in Groundwater from

New England Crystalline Rock Aquifers.....................................................................66

Summary and Conclusions....................................................................................................

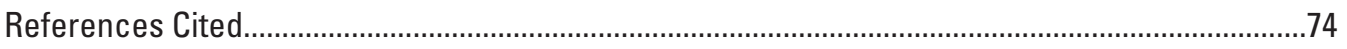

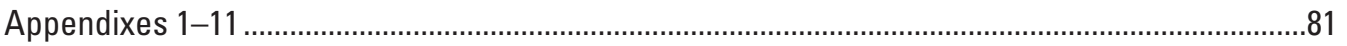

\section{Figures}

1. Map showing location of 117 domestic wells completed in New England crystalline rock aquifers in New England, New Jersey, and New York, and sampled for the U.S. Geological Survey National Water-Quality Assessment Program, 1995-2007 ..........3

2. Maps showing location of $4,775 A$, community, $B$, transient noncommunity, and $C$, nontransient noncommunity wells used for public supply, completed in New England crystalline rock aquifers in New England, and sampled for the U.S. Environmental Protection Agency Safe Drinking Water Act Program, 1997-2007.

3. Boxplots showing distributions of $A$, undeveloped, $B$, developed, and $C$, agricultural land uses within 500-meter radius of the public-supply and domestic wells, by percentage of area, in New England crystalline rock aquifers for the year 2001

4. Boxplots showing distribution of population densities, by persons per square kilometer, in a 500-meter radius of the public-supply and domestic wells in New England crystalline rock aquifers for the year 2000.

5. Maps showing general distribution of $A$, major lithology categories and $B$, of lithology groups of New England crystalline rock aquifers, in New England, New Jersey, and New York

6. Map showing spatial distribution of $\mathrm{pH}$ values in water samples collected from domestic and public-supply wells in New England crystalline rock aquifers, 1995-2007.

7. Boxplots showing distribution of $A, \mathrm{pH}$ values and $B$, concentrations of dissolved oxygen in water samples collected from public-supply and domestic wells in New England crystalline rock aquifers, 1995-2007

8. Maps showing spatial distributions of $A$, concentrations of nitrate in water samples from domestic and public-supply wells in New England crystalline rock aquifers, 1995-2007, and B, population density in New England and parts of New Jersey and New York for the year 2000

9. Bar graphs showing distribution of percentages of water samples with concentrations of nitrate greater than 1 milligram per liter collected from public-supply and domestic wells in New England crystalline rock aquifers, by categories of population density, 1995-2007.

10. Bar graphs showing distribution of percentages of water samples with concentrations of nitrate greater than 1 milligram per liter collected from public-supply and domestic wells in New England crystalline rock aquifers, by major category of land use within a 500-meter radius of the sampled wells, 1995-2007.

11. Bar graph showing distribution of percentages of water samples with concentrations of nitrate greater than 1 milligram per liter collected from public-supply and domestic wells in New England crystalline rock aquifers, by categories of well depth and casing length, 1995-2007.

12. Bar graphs showing distribution of percentages of water samples with concentrations of nitrate greater than $A, 0.5, B, 3$, and $C, 6$ milligrams per liter collected from publicsupply and domestic wells in New England crystalline rock aquifers, 1995-2007 
13. Trilinear diagram showing relations among major ions in water samples collected from domestic wells in New England crystalline rock aquifers, 1995-2000...

14. Map showing dominant water types in water samples collected from domestic wells in New England crystalline rock aquifers, 1995-2000

15. Map showing spatial distribution of chloride concentrations in water samples collected from domestic and public-supply wells in New England crystalline rock aquifers, 1995-2007.

16. Boxplots showing distribution of sodium and chloride concentrations in water samples collected from public-supply and domestic wells in New England crystalline rock aquifers, by categories of land use, 1995-2007 ...

17. Boxplots showing distribution of sodium and chloride concentrations in water samples collected from public-supply and domestic wells in New England crystalline rock aquifers, by categories of population density, 1995-2007.

18. Scatterplots showing chloride to bromide mass ratios in relation to $A$, chloride concentrations, $B$, sodium to chloride molar ratios, and $C, \mathrm{pH}$ in water samples collected from domestic wells in New England crystalline rock aquifers, 1995-2000 ...36

19. Map showing spatial distribution of fluoride concentrations in water samples collected from domestic and public-supply wells in New England crystalline rock aquifers, 1995-2007.

20. Boxplots showing distribution of $A$, concentrations of fluoride in water samples collected from public-supply and domestic wells in New England crystalline rock aquifers and $B$, bar graph showing percentages of these samples with concentrations of fluoride greater than the U.S. Environmental Protection Agency maximum contaminant level of 4 milligrams per liter, by lithology group, 1995-2007 ...

21. Map showing spatial distribution of manganese concentrations in water samples collected from domestic and public-supply wells in New England crystalline rock aquifers, 1995-2007.

22. Map showing spatial distributions of arsenic concentrations in water samples collected from domestic and public-supply wells in New England crystalline rock aquifers, 1995-2007

23. Bar graph showing distribution of percentages of water samples with concentrations of arsenic greater than 10 micrograms per liter collected from domestic wells in New England crystalline rock aquifers, by the National Water-Quality Assessment Program well network, 1995-2000

24. Bar graph showing distribution of percentages of water samples with concentrations of arsenic greater than 10 micrograms per liter collected from public-supply and domestic wells in New England crystalline rock aquifers, by categories of well depth and casing length, 1995-2007.

25. Boxplots showing distributions of $A$, concentrations of arsenic in water samples collected from public-supply and domestic wells in New England crystalline rock aquifers and $B$, bar graph showing percentages of these samples with concentrations of arsenic greater than the U.S. Environmental Protection Agency maximum contamination level of 10 micrograms per liter, by lithology group, 1995-2007.

26. Scatterplots showing relations of concentrations of arsenic in water samples collected from domestic wells in New England crystalline rock aquifers to $A, \mathrm{pH}$, and $B$, concentrations of nitrate, $1995-2000$.

27. Bar graph showing distribution of percentages of water samples collected from public-supply and domestic wells in New England crystalline rock aquifers with concentrations of arsenic greater than the U.S. Environmental Protection Agency maximum contaminant level of 10 micrograms per liter, by categories of $\mathrm{pH}$ and nitrate concentrations, 1995-2007. 
28. Map showing spatial distribution of gross alpha-particle activities in water samples collected from domestic and public-supply wells in New England crystalline rock aquifers, 1999-2007

29. Map showing spatial distribution of combined radium activities in water samples collected from domestic and public-supply wells in New England crystalline rock aquifers, 1999-2007

30. Map showing spatial distribution of ${ }^{222}$ radon activities in water samples collected from domestic and public-supply wells in New England crystalline rock aquifers, 1995-2007.

31. Boxplots showing distribution of $A$, activities of 222 radon in water samples collected from public-supply and domestic wells in New England crystalline rock aquifers, and $B$, bar graph showing percentages of these samples with activities of ${ }^{222}$ radon greater than the proposed alternative U.S. Environmental Protection Agency maximum contaminant level of 4,000 picocuries per liter, by lithology group, 1995-2007

32. Map showing spatial distribution of uranium concentrations in water samples collected from domestic and public-supply wells in New England crystalline rock aquifers, 1995-2007

33. Boxplots showing distribution of concentrations of uranium in water samples collected from domestic wells in New England crystalline rock aquifers, by the National Water-Quality Assessment Program well network, 1995-2000

34. Boxplots showing distribution of $A$, concentrations of uranium in water samples collected from public-supply and domestic wells in New England crystalline rock aquifers and $B$, bar graph showing percentages of these samples with concentrations of uranium greater than the U.S. Environmental Protection Agency maximum contaminant level of 30 micrograms per liter, by lithology group, 1995-2007

35. Bar graph showing detection frequencies for the nine most common volatile organic compounds in water samples collected from domestic wells in New England crystalline rock aquifers, 1995-2000

36. Map showing spatial distribution of chloroform concentrations in water samples collected from domestic wells in New England crystalline rock aquifers, 1995-2000 ...65

37. Map showing spatial distribution of methyl tert-butyl ether concentration in water samples collected from domestic and public-supply wells in New England crystalline rock aquifers, 1995-2007

38. Bar graphs showing distribution of percentages of water samples collected from public-supply and domestic wells in New England crystalline rock aquifers with concentrations of methyl tert-butyl ether greater than 1 microgram per liter, by categories of $A$, population density and $B$, land use, 1995-2007

39. Scatterplots showing concentrations of methyl tert-butyl ether in water samples collected from domestic wells in New England crystalline rock aquifers in relation to $A$, apparent year of recharge; $B$, dissolved oxygen concentrations; $C$, field $\mathrm{pH}$; $D$, depth to groundwater table; $E$, depth to bottom of well casing; and $F$, well depth, 1995-2000

40. Map showing location of six domestic trend wells in New England crystalline rock aquifers that were sampled biannually for the National Water-Quality Assessment Program to determine trends in selected physiochemical properties and waterquality constituents, 1999-2007

41. Plots showing $A$, water levels, $B, \mathrm{pH}$, and concentrations of $C$, dissolved oxygen, $D$, nitrate, $E$, arsenic, and $F$, methyl tert-butyl ether in water samples collected from six domestic trend wells in New England crystalline rock aquifers, 1999-2007. 


\section{Tables}

1. Sources of data used in this study, 1995-2007 ...............................................................6

2. Summary data on the 4,892 wells sampled, by state, source of data, and type of water system in New England, New Jersey, and New York, 1995-2007...

3. Inorganic and organic constituents detected in blank samples collected by the National Water-Quality Assessment Program studies in New England crystalline rock aquifers, in New England, New Jersey, and New York, 1995-2000

4. Number of untreated, unfiltered water samples analyzed for selected water-quality properties and constituents, collected for the U.S. Environmental Protection Agency Safe Drinking Water Act Program from public-supply wells in New England crystalline rock aquifers, by State, 1997-2007.

5. Distribution of domestic and public-supply wells in New England crystalline rock aquifers, by major categories of land use, population density, and well-construction properties

6. Summary statistics for selected well-construction properties of the domestic and public-supply wells in New England crystalline rock aquifers, 1995-2007.

7. Generalized description of the major lithology categories and lithology groups in the New England crystalline rock aquifers used in this report

8. Summary statistics for selected physiochemical properties and water-quality constituents in water samples collected from domestic and public-supply wells in New England crystalline rock aquifers, 1995-2007

9. Concentrations of selected water-quality constituents in water samples collected from domestic wells for the U.S. Geological Survey National Water-Quality Assessment Program and public-supply wells for the U.S. Environmental Protection Agency Safe Drinking Water Act Program in New England crystalline rock aquifers, 1995-2007, with exceedances of human health benchmarks and non-health guidelines.

10. Sources and quantities of nitrogen inputs in New England States and in New Jersey, 2002 and 2004

11. Rho values from Spearman correlations of selected physiochemical properties, major ions, dissolved gases, and trace elements with trace-element data in groundwater collected for the U.S. Geological Survey National Water-Quality Assessment Program from domestic wells in New England crystalline rock aquifers, 1995-2000.

12. Arsenic occurrence in groundwater at concentrations greater than the U.S. Environmental Protection Agency Maximum Contaminant Level, by previous studies

13. Rho and probability values from Spearman correlations among selected radionuclides and lead in groundwater collected from domestic and public-supply wells in New England crystalline rock aquifers, 1995-2007.

14. Summary of 344 water samples collected from domestic and public-supply wells in New England crystalline rock aquifers with co-occurrence of uranium concentrations, gross alpha activities, and ${ }^{222}$ radon activities exceeding existing or proposed human-health benchmarks, by lithology group, 1999-2007 


\section{Conversion Factors and Abbreviations}

\begin{tabular}{|c|c|c|}
\hline Multiply & By & To obtain \\
\hline \multicolumn{3}{|c|}{ Length } \\
\hline centimeter $(\mathrm{cm})$ & 0.3937 & inch (in.) \\
\hline millimeter (mm) & 0.03937 & inch (in.) \\
\hline meter (m) & 3.281 & foot (ft) \\
\hline kilometer (km) & 0.6214 & mile (mi) \\
\hline \multicolumn{3}{|c|}{ Area } \\
\hline square kilometer $\left(\mathrm{km}^{2}\right)$ & 0.3861 & square mile $\left(\mathrm{mi}^{2}\right)$ \\
\hline \multicolumn{3}{|c|}{ Volume } \\
\hline liter (L) & 0.2642 & gallon (gal) \\
\hline cubic meter $\left(\mathrm{m}^{3}\right)$ & 264.2 & gallon (gal) \\
\hline cubic centimeter $\left(\mathrm{cm}^{3}\right)$ & 0.06102 & cubic inch $\left(\right.$ in $\left.^{3}\right)$ \\
\hline \multicolumn{3}{|c|}{ Flow rate } \\
\hline liter per second $(\mathrm{L} / \mathrm{s})$ & 15.85 & gallon per minute (gal $/ \mathrm{min})$ \\
\hline cubic meter per day $\left(\mathrm{m}^{3} / \mathrm{d}\right)$ & 264.2 & gallon per day (gal/d) \\
\hline millimeter per year $(\mathrm{mm} / \mathrm{yr})$ & 0.03937 & inch per year (in/yr) \\
\hline \multicolumn{3}{|c|}{ Mass } \\
\hline gram (g) & 0.03527 & ounce, avoirdupois (oz) \\
\hline kilogram (kg) & 2.205 & pound avoirdupois (lb) \\
\hline metric ton per year & 1.102 & ton per year (ton/yr) \\
\hline \multicolumn{3}{|c|}{ Radioactivity } \\
\hline becquerel per liter $(\mathrm{Bq} / \mathrm{L})$ & 27.027 & picocurie per liter $(\mathrm{pCi} / \mathrm{L})$ \\
\hline
\end{tabular}

Temperature in degrees Celsius $\left({ }^{\circ} \mathrm{C}\right)$ may be converted to degrees Fahrenheit $\left({ }^{\circ} \mathrm{F}\right)$ as follows:

$$
{ }^{\circ} \mathrm{F}=\left(1.8 x^{\circ} \mathrm{C}\right)+32
$$

Temperature in degrees Fahrenheit $\left({ }^{\circ} \mathrm{F}\right)$ may be converted to degrees Celsius $\left({ }^{\circ} \mathrm{C}\right)$ as follows:

$$
{ }^{\circ} \mathrm{C}=\left({ }^{\circ} \mathrm{F}-32\right) / 1.8
$$

Specific conductance is given in microsiemens per centimeter at 25 degrees Celsius $(\mu \mathrm{S} / \mathrm{cm}$ at $\left.25^{\circ} \mathrm{C}\right)$.

Concentrations of chemical constituents in water or air are given in milligrams per liter $(\mathrm{mg} / \mathrm{L})$, micrograms per liter $(\mu \mathrm{g} / \mathrm{L})$, parts per billion $(\mathrm{ppb})$, milliequivalents per liter $(\mathrm{mEq} / \mathrm{L})$, or grams per kilogram $(\mathrm{g} / \mathrm{kg})$. 


\section{List of Abbreviations}

Al

AMCL

Ar

As

B

$\mathrm{Ba}$

$\mathrm{Be}$

$\mathrm{Br}$

BTEX

$\mathrm{Ca}$

$\mathrm{CaCO}_{3}$

CFC-11

CFC-12

CFC-113

$\mathrm{CH}_{4}$

CIAT

CONN

$\mathrm{CO}_{2}$

$\mathrm{CO}_{3}$

$\mathrm{Cr}$

DBCP

DCPA

1,1-DCA

1,1-DCE

1,2-DCE

DIPE

$\mathrm{DO}$ or $\mathrm{O}_{2}$

DOC

$\mathrm{E}$

EDB

EtBE

$\mathrm{F}$

$\mathrm{Fe}$

$\mathrm{Fe}^{2+}$

${ }^{2} \mathrm{H}$

HBSL

$\mathrm{HCO}_{3}$

$\mathrm{K}$

Li aluminum

alternative maximum contaminant level

argon gas

arsenic

boron

barium

beryllium

bromide

benzene, toluene, ethylbenzene, and xylene

calcium

calcium carbonate

trichlorofluoromethane

dichlorodifluoromethane

1,1,2-trichlorotrifluoroethane

methane gas

deethylatrazine, 2-chloro-4-isopropylamino-6-amino-s-triazine

Connecticut, Housatonic, and Thames River Basin

carbon dioxide gas

carbonate

chromium

dibromochloropropane

dimethyl tetrachloroterephthalate, trade name "Dacthal"

1,1-dichloroethane

1,1-dichloroethene

cis-1,2-dichloroethene

diisopropyl ether

dissolved oxygen

dissolved organic carbon

estimated concentration

ethylene dibromide

ethyl-tert-butyl ether

fluoride

iron

ferrous iron

deuterium, or hydrogen-2

health-based screening level

bicarbonate

potassium

lithium 


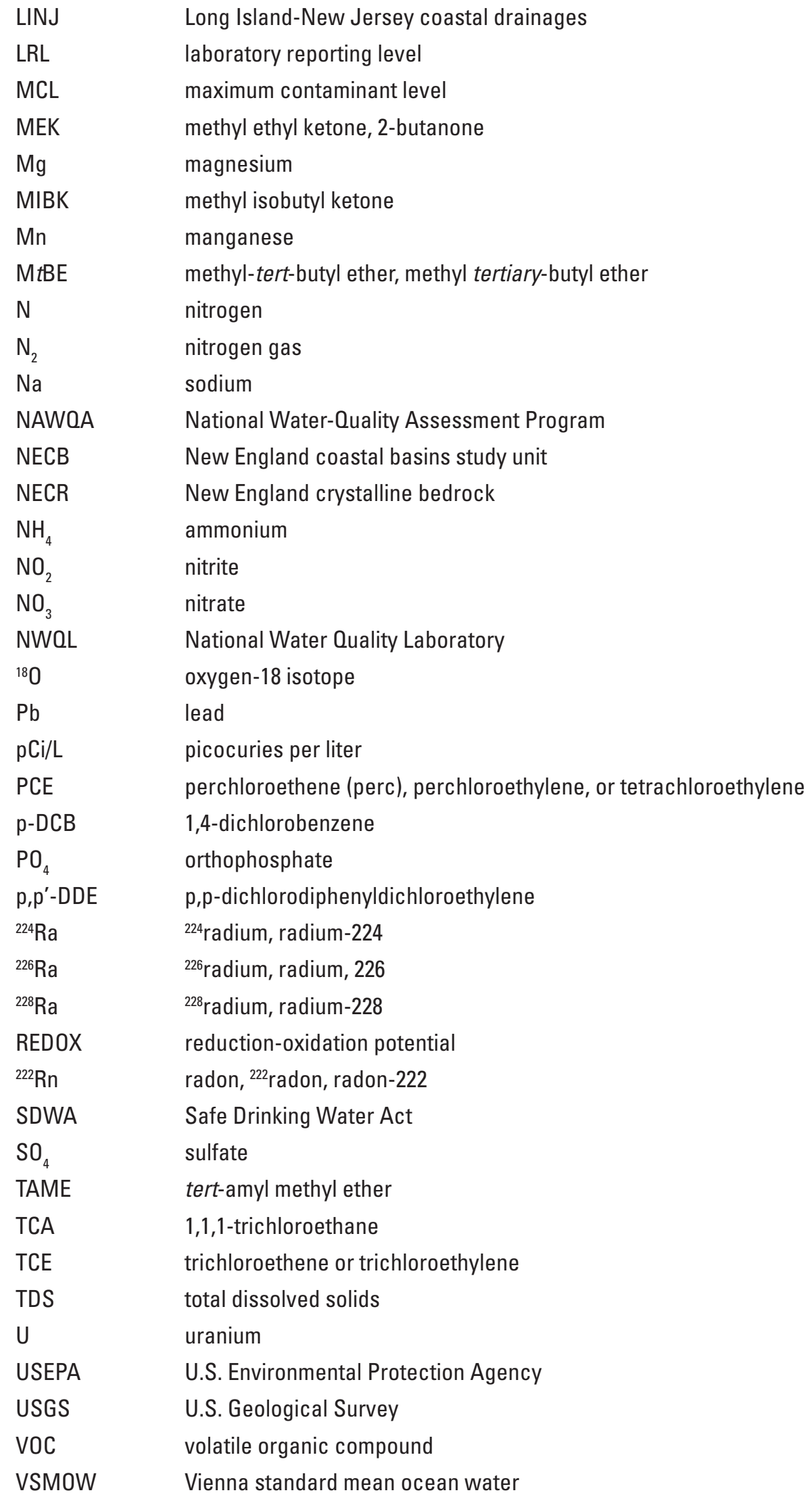




\title{
Quality of Water from Crystalline Rock Aquifers in New England, New Jersey, and New York, 1995-2007
}

\author{
By Sarah M. Flanagan, Joseph D. Ayotte, and Gilpin R. Robinson, Jr.
}

\section{Abstract}

Crystalline bedrock aquifers in New England and parts of New Jersey and New York (NECR aquifers) are a major source of drinking water. Because the quality of water in these aquifers is highly variable, the U.S. Geological Survey (USGS) statistically analyzed chemical data on samples of untreated groundwater collected from 117 domestic bedrock wells in New England, New York, and New Jersey, and from 4,775 public-supply bedrock wells in New England to characterize the quality of the groundwater. The domesticwell data were from samples collected by the USGS National Water-Quality Assessment (NAWQA) Program from 1995 through 2007. The public-supply-well data were from samples collected for the U.S. Environmental Protection Agency (USEPA) Safe Drinking Water Act (SDWA) Program from 1997 through 2007. Chemical data compiled from the domestic wells include $\mathrm{pH}$, specific conductance, dissolved oxygen, alkalinity, and turbidity; 6 nitrogen and phosphorus compounds, 14 major ions, 23 trace elements, ${ }^{222}$ radon gas (radon), 48 pesticide compounds, and 82 volatile organic compounds (VOCs). Additional samples were collected from the domestic wells for the analysis of gross alpha- and gross beta-particle radioactivity, radium isotopes, chlorofluorocarbon isotopes, and the dissolved gases methane, carbon dioxide, nitrogen, and argon. Chemical data compiled from the public-supply wells include $\mathrm{pH}$, specific conductance, nitrate, iron, manganese, sodium, chloride, fluoride, arsenic, uranium, radon, combined radium ( ${ }^{226}$ radium plus ${ }^{228}$ radium), gross alpha-particle radioactivity, and methyl tert-butyl ether (MtBE).

Patterns in fluoride, arsenic, uranium, and radon distributions were discernable when the data were compared to lithology groupings of the bedrock, indicating that the type of bedrock has an effect on the quality of groundwater from NECR aquifers. Fluoride concentrations were significantly higher in groundwater samples from the alkali granite, peraluminous granite, and metaluminous granite lithology groups than from samples in the other lithology groups. Water samples from 1.4 percent of 2,167 studied wells had fluoride concentrations that were equal to or greater than the maximum contaminant level (MCL) of 4 milligrams per liter $(\mathrm{mg} / \mathrm{L})$ and 7.5 percent of the wells had fluoride concentrations that were equal to or greater than the secondary MCL of $2 \mathrm{mg} / \mathrm{L}$. For arsenic, groundwater samples from the calcareous metasedimentary rocks in the New Hampshire-Maine geologic province, peraluminous granite, and pelitic rocks lithology groups had higher concentrations than did samples from the other lithology groups. Water samples from 13.3 percent of 2,054 studied wells had arsenic concentrations that were equal to or greater than the MCL of 10 micrograms per liter $(\mu \mathrm{g} / \mathrm{L})$, about double the national rate of occurrence in communitysupply systems and in domestic wells of the United States. Uranium concentrations were significantly higher in groundwater samples from the peraluminous granite, alkali granite, and calcareous metasedimentary rocks in the New HampshireMaine geologic province lithology groups than from samples in the other lithology groups. Water samples from 14.2 percent of 556 studied wells had uranium concentrations equal to or greater than the MCL of $30 \mu \mathrm{g} / \mathrm{L}$. Radon activities were equal to or greater than the proposed MCL of 300 picocuries per liter (pCi/L) in 95 percent of 943 studied wells, and 33 percent of the wells had radon activities were equal to or greater than the proposed alternative maximum contaminant level (AMCL) of $4,000 \mathrm{pCi} / \mathrm{L}$. Radon activities exceeded the proposed AMCL in 20 percent or more of groundwater samples in each of the studied lithology groups with a minimum of 9 samples, but radon activities were significantly higher in groundwater samples from the alkali granite, peraluminous granite, and Narragansett basin metasedimentary rocks lithology groups. Water samples from 3.2 percent of 564 studied wells had combined radium activities equal to or greater than the MCL of $5 \mathrm{pCi} / \mathrm{L}$; however, combined radium activities were not significantly different among the studied lithology groups.

Land use and population density also were evaluated to explain patterns in water quality. Concentrations of nitrate, sodium, chloride, and $\mathrm{M} t \mathrm{BE}$ from the studied wells were significantly greater in areas of high population density ( $\geq 50$ persons per square kilometer) than in areas of low population density ( $<50$ persons per square kilometer). Concentrations of sodium, chloride, and $\mathrm{M} t \mathrm{BE}$ from the studied wells were significantly greater in areas classified as developed (urban lands) than in areas classified as undeveloped (forested), agricultural, or mixed (no dominant land use). Nitrate concentrations from the public-supply wells were not significantly different among the four land use categories, but nitrate concentrations from the domestic wells were significantly greater in areas classified as developed than in areas classified as undeveloped, agricultural, or mixed. 
Chloride to bromide mass ratios in the domestic well samples indicate that the groundwater was probably affected by at least three halogen sources: local precipitation and recharge waters, remnant seawater and connate waters evolved from seawater, and recharge waters affected by road salt. The groundwater in the NECR aquifers generally contained low concentrations of nitrate, VOCs, and pesticides. Less than 1 percent of water samples from 4,781 studied wells had concentrations of nitrate greater than the MCL of $10 \mathrm{mg} / \mathrm{L}$. Less than 1 percent of water samples from 1,299 studied wells exceeded the USEPA advisory level of 20 to $40 \mu \mathrm{g} / \mathrm{L}$ for M $t \mathrm{BE}$. None of the other studied VOCs exceeded a human health benchmark. MtBE (36 percent frequency detection) and chloroform (32.9 percent frequency detection) were the most frequently detected $(>0.02 \mu \mathrm{g} / \mathrm{L})$ VOCs in the domestic wells. MtBE was detected more often in water samples with apparent ages of less than 25 years than in water samples with apparent ages greater than 25 years. This finding is consistent with the time period of high $\mathrm{M} t \mathrm{BE}$ use in areas in the United States where reformulated gasoline was mandated. The largest pesticide concentration was an estimated concentration of $0.06 \mu \mathrm{g} / \mathrm{L}$ for the herbicide metolachlor. Deethylatrazine, a degradate of atrazine, (18 percent frequency detection) and atrazine ( 8 percent frequency detection) were the only pesticide compounds detected $(>0.001 \mu \mathrm{g} / \mathrm{L})$ in more than 3 percent of the domestic wells. None of the detected pesticide compounds exceeded human health benchmarks.

Concentrations of nitrate and gross alpha-particle activities were significantly greater in the water samples from the domestic wells than in samples from the public-supply wells. Concentrations of sodium, chloride, iron, manganese, and uranium were significantly greater in the water samples from the public-supply wells than in the samples from the domestic wells. One possible explanation may be related to differences in field processing (filtered samples from the domestic wells compared to unfiltered samples from the public-supply wells).

The high frequency of detections for a wide variety of manmade and naturally occurring contaminants in both domestic and public-supply wells shows the vulnerability of NECR aquifers to contamination. The highly variable water quality and the association with highly variable lithology of crystalline bedrock underscores the importance of testing individual wells to determine if concentrations for the most commonly detected contaminants exceed human health benchmarks.

\section{Introduction}

The U.S. Geological Survey (USGS) National Water-Quality Assessment (NAWQA) Program assesses groundwater-quality conditions and trends in 19 principal aquifers across the Nation that are major sources of public and domestic-supply drinking water (Lapham and others, 2005). These regional-scale aquifer assessments complement and extend the findings of small-scale studies. One of the groups of principal aquifers being studied are the New England crystalline rock (NECR) aquifers (fig. 1). Often called "fractured bedrock," crystalline rock aquifers are the most extensive and widely available aquifers in New England, in a small part of northern New Jersey, and in northcentral New York. About 74 million gallons of groundwater were withdrawn per day (Mgal/d) from NECR aquifers for public supply, $49 \mathrm{Mgal} / \mathrm{d}$ for domestic supply, $12 \mathrm{Mgal} / \mathrm{d}$ for self-supplied industrial use, and $11 \mathrm{Mgal} / \mathrm{d}$ for irrigation use (Maupin and Barber, 2005; Maupin and Arnold, 2010). The U.S. Environmental Protection Agency (USEPA) has estimated that about 2.3 million people (about 20 percent New England's population) obtain drinking water from their own private (domestic) well (accessed April 15, 2012, at http://www.epa.gov/region1/eco/drinkwater/private_well_ owners.html) and NECR aquifers are the dominant source of water to these wells.

Yields and quality of groundwater from wells completed in New England bedrock aquifers are greatly affected by the hydraulic properties of the aquifer, which include the degree of foliation in the bedrock formations and the extent, size, and number of water-bearing fractures. The quality of natural bedrock groundwater also is affected by the chemistry of precipitation (primary source of recharge), biological processes, characteristics of soil and surficial sediments, length of residence time in the aquifer, and aquifer materials.

In part because of the complex geology, fracture heterogeneity, and tectonic history of crystalline rock in New England, the water quality of the NECR aquifers is highly variable, and the chemistry of the groundwater can differ substantially from well to well, even among wells that are in close proximity. Thus, a framework approach for assessing NECR aquifers on a regional scale was prepared (Harte and others, 2008) and used to evaluate available water-quality data.

\section{Purpose and Scope}

This report summarizes water-quality data for domestic and public-supply wells completed in the NECR principal aquifer system in the six New England States and a small part of northern New Jersey and southern New York. The data from the domestic wells were from water samples collected for the NAWQA Program during 1995-2000, and the data from the public-supply wells were from water samples collected for the USEPA Safe Drinking Water Act (SDWA) Program during 1997-2007. The report describes the occurrence of contaminants - arsenic, uranium, fluoride, gas ( ${ }^{222}$ radon), combined radium $\left({ }^{226} \mathrm{Ra}+{ }^{228} \mathrm{Ra}\right)$, and gross alpha-particle activity-in the context of a regional lithologic and geochemical framework. Nitrate, sodium, chloride, and MtBE are examined by categories of land use and population density. Major ion chemistry, selected trace elements, volatile organic compounds (VOCs), and pesticides also are evaluated. Factors that relate to constituent concentrations greater than selected threshold levels are evaluated. The report provides a preliminary assessment of trends in water quality based on water samples collected biennially for six domestic wells during 1999-2007. 


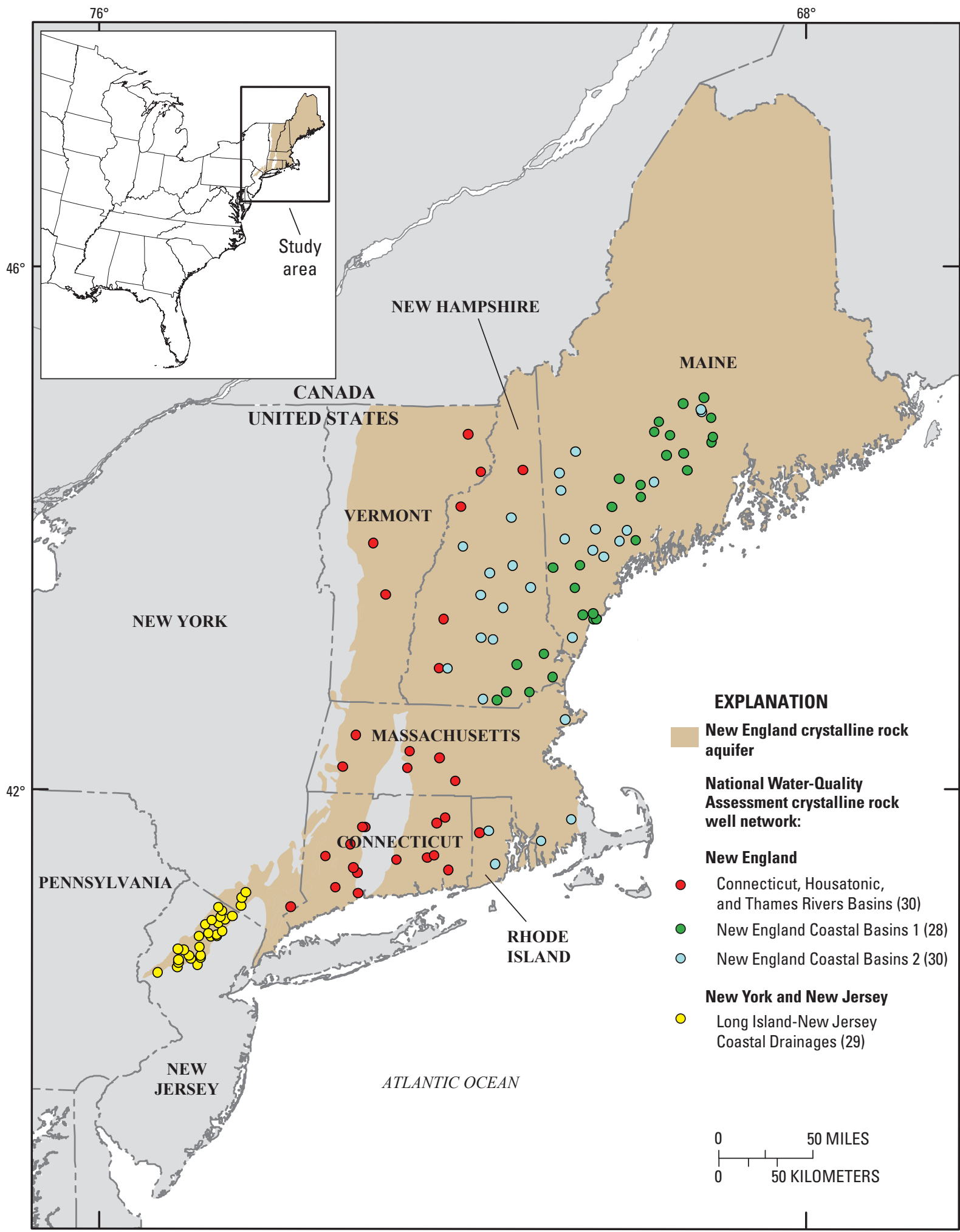

Base from U.S. Geological Survey digital data, 1:2,000,000, Albers Projection

Study area modified from U.S. Geological Survey Ground Water Atlas of the United States (Olcott, 1995)

Figure 1. Location of 117 domestic wells completed in New England crystalline rock aquifers in New England, New Jersey, and New York, and sampled for the U.S. Geological Survey National Water-Quality Assessment Program, 1995-2007. The Connecticut, Housatonic, and Thames Rivers Basins and the Long Island-New Jersey Coastal Drainages well networks comprise undifferentiated crystalline rock; the New England Coastal Basins well network 1 comprises predominantly calcareous metasedimentary rocks; and the New England Coastal Basins well network 2 comprises predominantly felsic igneous and pelitic rocks. 


\section{Description of Study Area}

NECR aquifers underlie an area of approximately 72,000 square miles (Harte and others, 2008). It includes a small area in northern New Jersey, a narrow band across southern New York, and a majority of the land area in the New England States of Connecticut, Massachusetts, Maine, New Hampshire, Rhode Island, and Vermont (fig. 1). A large area of crystalline bedrock occurs in northern New York (Harte and others, 2008), but was not evaluated in this study.

Areas of New England bedrock that are not considered crystalline were not studied. These areas include (1) Cape Cod and the major offshore islands in southeastern Massachusetts where the bedrock is overlain with thick deposits of unconsolidated glacial sediments, (2) the clastic sedimentary and igneous rocks in the Mesozoic basins in central Connecticut and Massachusetts that are layered and largely unmetamorphosed, and (3) the predominantly unmetamorphosed bedded carbonate rocks in western parts of Connecticut, Massachusetts, and Vermont that are part of the "Grenville Shelf Sequence" geologic province (Robinson and Kapo, 2003; fig. 1).

A wide variety of igneous and metamorphic rocks of various metamorphic grades compose NECR aquifers (Zimmerman and others, 1996; Robinson, 1997; Flanagan and others, 1999). These rocks, ranging in age from the Precambrian to the Cretaceous, are folded, faulted, and foliated. They commonly exhibit preferential joint and stressrelief fractures as a result of tectonic activity, cooling stresses associated with igneous intrusion, rock erosion, and most recently, the melting of glacial ice sheets that once covered New England (Hanson and Simcox, 1994; Flanagan and others, 1999; Harte and others, 2008). Harte and others (2008) describes in detail the physical setting and geohydrology of NECR aquifers.

Much of New England is thinly mantled by glacial till, and many of the glacially broadened valleys have glacial outwash deposits overlain with thin soils. Where glacial deposits are thin or nonexistent, crystalline rock is the primary source of groundwater. The glacially derived soils of New England are generally deficient in nutrients, but they are well suited for forest growth because of the area's humid, temperate climate of warm, moist summers and cold, snowy winters (Flanagan and others, 1999). Mean annual precipitation (1961-90) is relatively high, ranging from less than 34 to about 50 inches per year, and increases toward the Atlantic coast and at higher elevations (Harte and others, 2008). New England has some of the highest rates of runoff in the United States due to the relatively high topographic relief in the Green Mountains, White Mountains, and Appalachian Mountains in Maine, New Hampshire, and Vermont (Kontis and others, 2004). High runoff rates, combined with a glaciated terrain dominated by thin soils, result in a landscape that contains numerous rivers, streams, lakes, ponds, and wetlands.

The dominant land cover overlying the NECR aquifers in New England is forested land, primarily in the States of Maine, New Hampshire, and Vermont, which covers about
61 percent of New England (U.S. Geological Survey, 2006; Harte and others, 2008). Open waters cover 13 percent, and wetlands cover about 7 percent. Developed (or urban) land accounts for about 8 percent; agricultural land, about 7 percent; and shrub land, about 4 percent (U.S. Geological Survey, 2006). Although developed and agricultural lands combined cover less than 15 percent of New England, these uses of the land can have a disproportionately greater effect on groundwater quality than other land uses (Robinson and others, 2004).

The spatial distribution of these land uses and land cover in New England is highly variable. The densely populated urban areas in the southern New England States of Connecticut, Rhode Island, and Massachusetts include the major cities of Hartford, Providence, and Boston; nearby cities; and suburban areas. High-traffic interstate highways are present in these areas. Many small cities were, over a century ago, factory or mill towns that took advantage of New England's hydropower resources to power the region's paper mills and factories (Zimmerman and others, 1996; Flanagan and others, 1999). Small farms are scattered throughout the valley lowland and coastal areas of New England, but they are located primarily in western Vermont, northeastern Maine, and the Connecticut River valley in Massachusetts and Connecticut (Harte and others, 2008). The small part of the study area in northern New Jersey and southern New York consists of densely populated suburban lands that have developed as expansions of the nearby cities of New York and Philadelphia (Ayers and others, 2000).

\section{Previous Investigations}

Harte and others (2008) summarizes the results of many small-scale studies that focused on water-availability issues and selected contaminants in NECR aquifers. Recent smallscale (county) and multi-State-scale studies of individual contaminants have shown that the NECR aquifers are vulnerable to contamination by arsenic (Peters and others, 1999; Montgomery and others, 2003; Moore, 2004; Ayotte and others, 2006) and methyl tert-butyl ether (MtBE) (Maine Department of Human Services, 1998; Peckenham, 2002; Ayotte and others, 2004, 2005, 2008). Ayotte and others (1999) examined relations among arsenic (As), iron (Fe), and manganese $(\mathrm{Mn})$ concentrations in groundwater from bedrock aquifers in eastern New England with rock type and generalized geologic lithology. The MtBE studies found that $\mathrm{M} t \mathrm{BE}$ concentrations in private bedrock wells in New Hampshire and Maine were related to urban factors, such as population density, housing density, and the percentages of urban land use and roads within 500-meter (m) radius surrounding the wells. The arsenic studies identified bedrock lithology and redox conditions as important explanatory variables in predicting arsenic concentrations. In particular, high arsenic concentrations [ $>10$ micrograms per liter $(\mu \mathrm{g} / \mathrm{L})]$ were associated with a lithostratigraphic belt of calcareous 
metasedimentary rocks in eastern New England, high $\mathrm{pH}$ (7.0-8.5) and low dissolved oxygen (DO) concentrations $[(<1$ milligram per liter $(\mathrm{mg} / \mathrm{L})]$.

On a national scale, the NAWQA Program conducted an assessment by DeSimone (2009) of water-quality conditions in about 2,170 domestic wells sampled for the NAWQA Program, in all major aquifer systems across the United States. DeSimone and others (2009) provide an overview of major findings for this study. Zogorski and others (2006) and Gilliom and others (2006) describe the major findings of the NAWQA Program on volatile organic compounds in samples from public-supply and domestic wells, and on pesticides in surface water and groundwater from local-scale NAWQA studies. These and other studies done by the NAWQA Program on the occurrence, distribution, fate, and other factors relating to the concentrations of nutrients, trace elements, VOCs, and pesticides in groundwater in the United States are available at http://water.usgs.gov/nawqa/.

\section{Study Design}

The design of this study was based on including as many drinking-water supply wells as possible to assess the ambient groundwater-quality of NECR aquifers on a regional scale. As a result, the data used in this study are biased towards areas where the aquifer is most used for public drinking-water supply. The groundwater-quality data analyzed in this report are for 117 domestic wells sampled by the USGS NAWQA Program during 1995-2007 (fig. 1, table 1) and for 4,775 public-supply wells sampled by the USEPA Safe Drinking Water Act (SDWA) Program during 1997-2007 (fig. 2, table 1). The SDWA Program provided the additional waterquality data in order to allow, where available, a regional comparison of water-quality data from domestic and publicsupply wells in New England. Some of those SDWA data have limitations, such as incomplete water-quality datasets or higher laboratory reporting levels (LRLs) than the NAWQA data, but the data were nonetheless available for expanding the spatial coverage of water-quality conditions for many waterquality constituents. Analyses reported here are for untreated groundwater and exclude treated (finished) water produced by municipal water-treatment or in-home water-treatment systems. Municipal water-treatment plants or in-home systems produce water that may be chemically different from that described in this report. Where applicable, water-quality data from the domestic and public-supply well samples are compared to USEPA proposed and enforceable maximum contaminant levels (MCLs) and secondary MCLs (SMCLs), which technically apply only to community water systems (U.S. Environmental Protection Agency, 2009).

Harte and others (2008) suggest that the relation between physical and chemical processes may be useful for the analysis of factors controlling the quality of groundwater from NECR aquifers. The framework approach described in Harte and others (2008) incorporates explanatory variables (features), including (1) geologic factors, (2) aquifer hydraulics, (3) land use and land cover, and (4) geochemical factors. On a regional scale, these features may be related to indicators of natural and anthropogenic sources of contaminants, as well as indicators of the physical characteristics of the aquifer systems that affect groundwater chemistry. In this study, water-quality concentrations of some constituents were compared to some of these variables to determine relations among the regional groundwater quality and these variables.

\section{Data from USGS NAWOA Domestic Wells}

The 117 domestic wells sampled by the three NAWQA studies were selected randomly, without consideration of the surrounding land uses, within each NAWQA study boundary in accordance with NAWQA protocols (Lapham and others, 1995) using procedures described by Scott (1990). Thirty domestic wells, primarily in Connecticut and Massachusetts, were sampled in 1995 for the Connecticut, Housatonic, and Thames Rivers Basins (CONN) NAWQA well network (fig. 1, tables 1-2) (Garabedian and others, 1998). For the CONN study, wells were selected randomly in areas of crystalline rock (described by Grady and Mullany, 1998) without consideration of the underlying geology. Twenty-six domestic wells in New Jersey and three domestic wells in New York were sampled in 1997 for the Long Island-New York-New Jersey Coastal Drainages (LINJ) well network (fig. 1, tables 1-2) (Ayers and others, 2000). For the LINJ study, wells within a small area of crystalline rock in northern New Jersey and in southeastern New York were selected (fig. 1).

During 1999 and 2000, the New England Coastal Basins (NECB) study sampled 58 domestic bedrock wells, primarily in Maine and New Hampshire (fig. 1, tables 1-2) (Robinson and others, 2004). Although the CONN wells were randomly chosen from all areas of crystalline bedrock within the study boundary, the wells sampled by the NECB study were randomly chosen within selected geologic lithologies. One NECB well network consists of 28 domestic bedrock wells in Maine and New Hampshire (fig. 1), in areas where the geologic units are dominated by calcareous metasedimentary rocks and where arsenic is likely to occur in groundwater (Ayotte and others, 2003; Robinson and others, 2004). Six of the 28 wells in this network also were sampled up to four times from 2003 to 2007. The other NECB well network consists of 30 domestic bedrock wells in Maine, New Hampshire, Massachusetts, and Rhode Island (fig. 1), in areas where the geologic units are dominated by felsic igneous and pelitic rocks and where uranium (U) and other radiochemicals are likely to occur in groundwater (Robinson and others, 2004). Ayotte and others (2003) analyzed, in detail, factors related to arsenic occurrence in these two well networks.

NAWQA water samples were collected and analyzed to determine physiochemical properties (dissolved oxygen, $\mathrm{pH}$, specific conductance, water temperature, and turbidity) and 


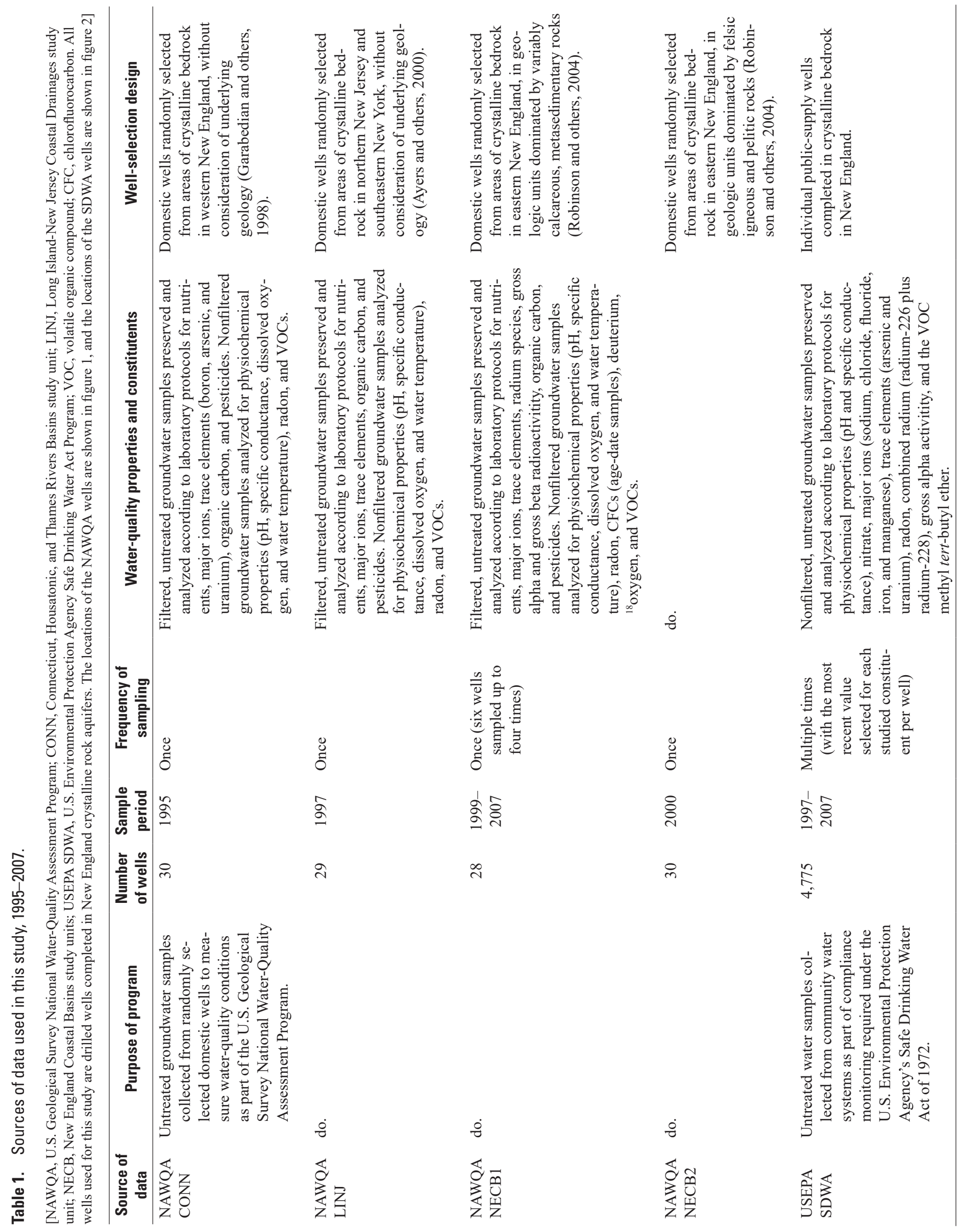



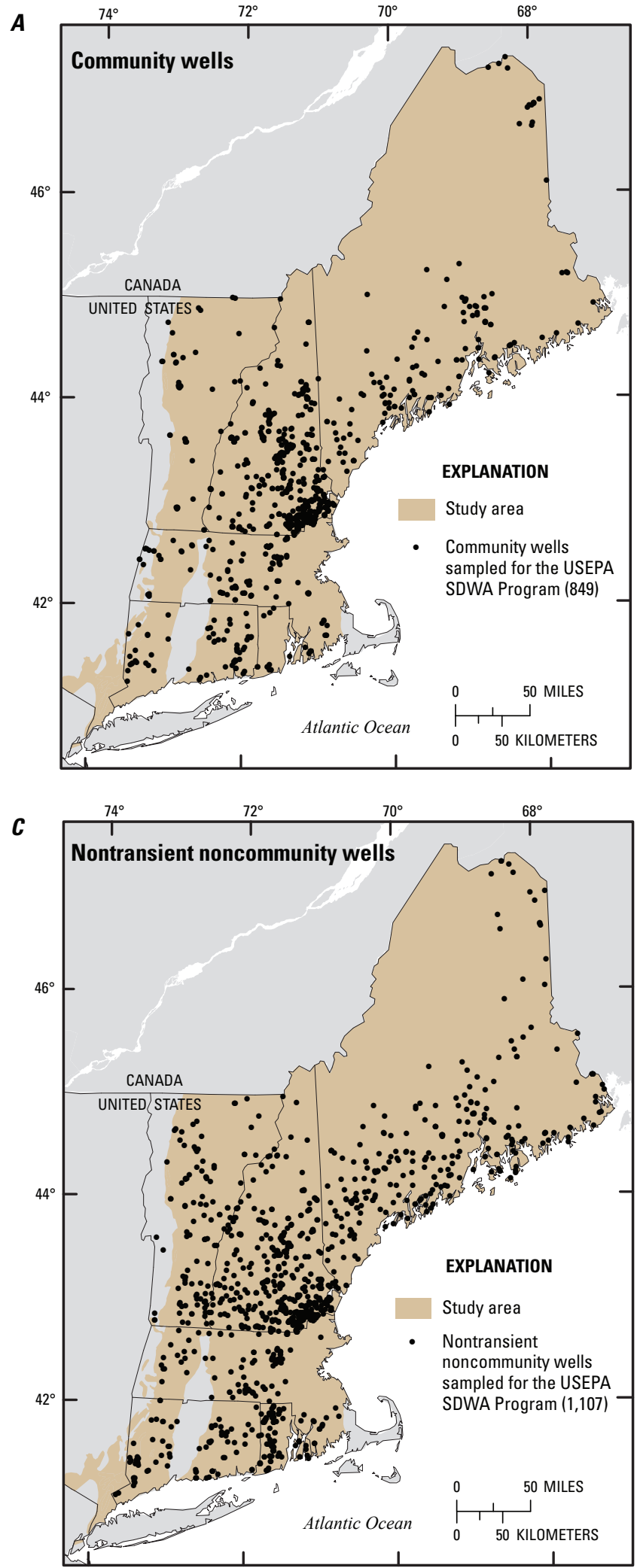

Base from U.S. Geological Survey digital data, 1:2,000,000, Albers Projection

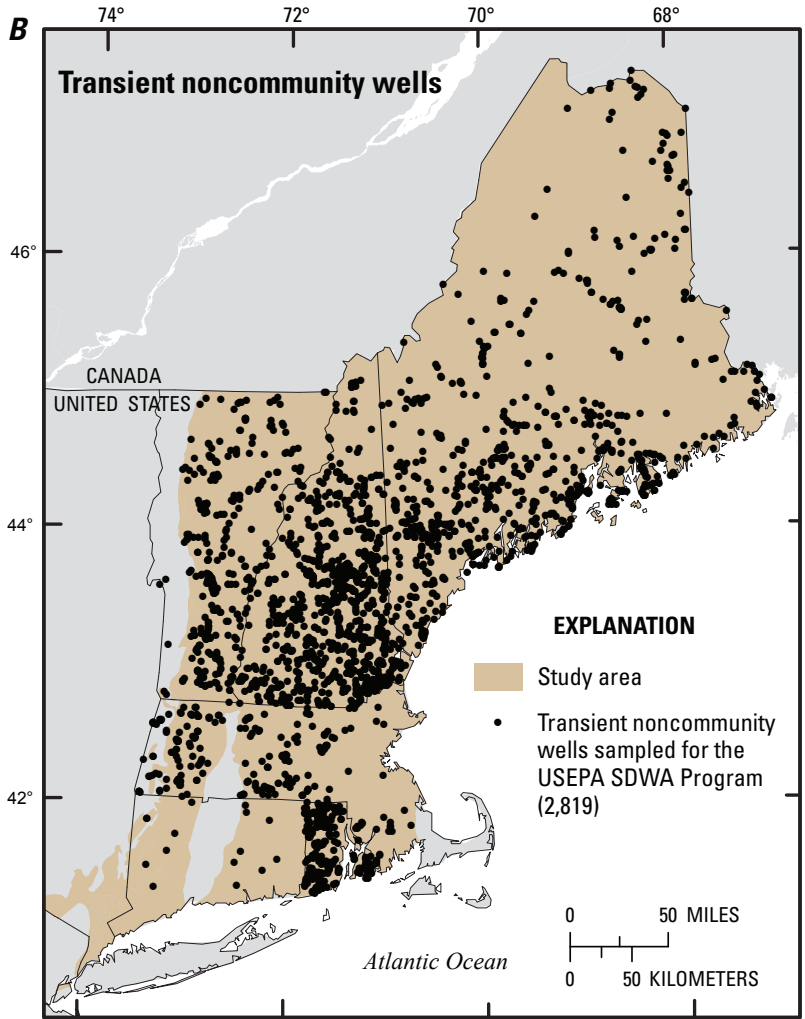

Base from U.S. Geological Survey digital data, 1:2,000,000,

Study area modified from U.S. Geological Survey Ground Water Atlas of the United States
(Olcott, 1995).

Figure 2. Location of $4,775 A$, community, $B$, transient noncommunity, and $C$, nontransient noncommunity wells used for public supply, completed in New England crystalline rock aquifers in New England, and sampled for the U.S. Environmental Protection Agency Safe Drinking Water Act Program, 1997-2007. The number of wells and types of water system are listed, by state, in table 2 . 
Table 2. Summary data on the 4,892 wells sampled, by state, source of data, and type of water system in New England, New Jersey, and New York, 1995-2007.

[N, number of sampled wells; USGS NAWQA, U.S. Geological Survey National Water-Quality Assessment; USEPA SDWA, U.S. Environmental Protection Agency Safe Drinking Water Act; LINJ, Long Island-New Jersey Coastal Drainages; CONN, Connecticut, Housatonic, and Thames Rivers Basins; NECB, New England Coastal Basins; COM, community water system; TNC, transient, noncommunity water system; NTNC, nontransient noncommunity water system]

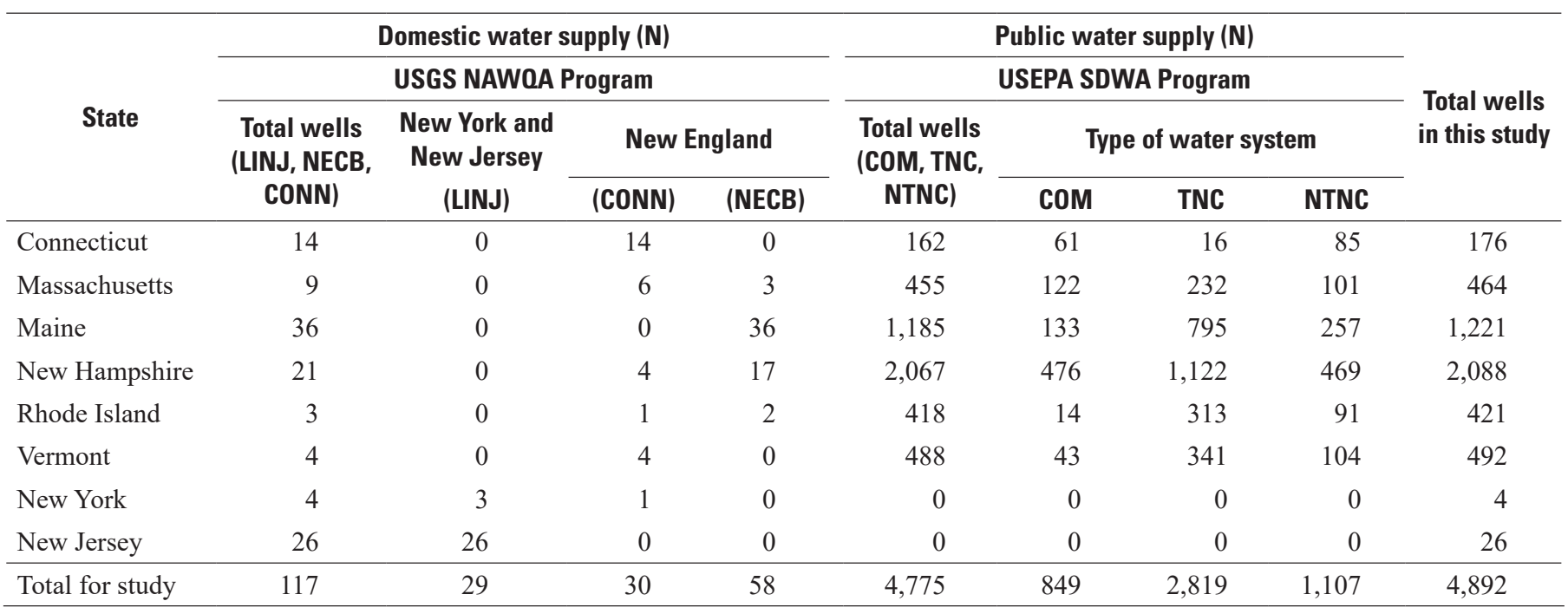

concentrations of major ions, nitrogen $(\mathrm{N})$ and phosphorus $(\mathrm{P})$ compounds, trace elements, dissolved organic carbon (DOC), selected pesticides and pesticide degradates, and selected VOCs, using field procedures described in the USGS national field manual (U.S. Geological Survey, variously dated) and in accordance with NAWQA protocols (Koterba and others, 1995; Lapham and others, 1995). In addition, personnel from the NECB study collected water samples for the analysis of gross alpha- and gross beta-particle radioactivity, radium species $\left({ }^{224} \mathrm{Ra},{ }^{226} \mathrm{Ra}\right.$, and $\left.{ }^{228} \mathrm{Ra}\right)$, dissolved atmospheric gases [Argon (Ar), carbon dioxide $\left(\mathrm{CO}_{2}\right)$, methane $\left(\mathrm{CH}_{4}\right)$, and nitrogen $\left(\mathrm{N}_{2}\right)$, the stable isotopes deuterium $\left({ }^{2} \mathrm{H}\right)$ and ${ }^{18}$ oxygen $\left({ }^{18} \mathrm{O}\right)$ ], and chlorofluorocarbons (CFCs).

NAWQA water samples were collected as close to the wellhead as possible, before household treatment, and just prior to the pressure tank. Specific conductance, $\mathrm{pH}$, dissolved oxygen (DO), and water temperature were measured in the absence of air until readings were stable (Koterba and others, 1995). Once measurements stabilized, water samples were then collected in pre-cleaned bottles, processed, and preserved according to NAWQA protocols (Koterba and others, 1995).

Most of the NAWQA inorganic and pesticide data are from filtered water samples because some laboratory equipment requires sediment removal prior to analysis and filtration removes the sediment bias that might occur when these data are analyzed on national or regional scales. Filtered samples for nutrients, major ions, and trace elements were analyzed for at the USGS National Water Quality Laboratory (NWQL) in Denver, Colorado, using inductively coupled plasma mass spectrometry (ICP/MS). Filtered samples for pesticides and pesticide-degradates were analyzed for at the USGS NWQL using C-18 solid phase extraction and capillary-column gas chromatograph/mass spectrometry (Furlong and others, 2001). Filtered samples for dissolved organic carbon were analyzed for at the USGS NWQL using ultraviolet light-promoted persulfate oxidation and nondispersive infrared spectrometry (Brenton and Arnett, 1993). Filtered samples for gross alpha- and gross beta-particle radioactivity were analyzed for at the USGS NWQL using low background Planchet counting post-evaporation (USEPA method 900.0; U.S. Environmental Protection Agency, 1980). Filtered samples for selected isotopes of radium species $\left({ }^{226} \mathrm{Ra}\right.$ and ${ }^{228} \mathrm{Ra}$ ) were analyzed for at Severn Trent Laboratories in Richland, Washington, using methods described by McCurdy and others (2008) or by alpha and gamma spectral methods (Focazio and others, 2001; Szabo and others, 2005; Zoltan Szabo, U.S. Geological Survey, written commun., 2007).

Unfiltered samples for VOCs were analyzed at the USGS NWQL using purge and trap capillary-column gas chromatography/mass spectrometry (Rose and Schroeder, 1995; Conner and others, 1998). Unfiltered, stable isotope samples were analyzed for ${ }^{2} \mathrm{H}$ and ${ }^{18} \mathrm{O}$ at the USGS Reston Stable Isotope Laboratory in Reston, Virginia, using the methods described in Epstein and Mayeda (1953) and Coplen and others (1991). ${ }^{2} \mathrm{H}$ and ${ }^{18} \mathrm{O}$ are reported as ratios per mill (\%o, or per thousand) of ${ }^{2} \mathrm{H} /{ }^{1} \mathrm{H}(\delta \mathrm{D})$ and ${ }^{18} \mathrm{O} /{ }^{16} \mathrm{O}\left(\delta^{18} \mathrm{O}\right)$, respectively, and are referenced to Vienna Standard Mean Ocean Water (VSMOW; $\delta \mathrm{D}$ and $\delta^{18} \mathrm{O}=0 \%$ ). 
Measurements of the concentrations of atmospheric gases and CFCs were used to interpret the apparent residence times (ages) of groundwater in 55 unfiltered water samples from domestic wells in the NECB study (table 1). For data in this study, the apparent ages of groundwater were calculated from water samples collected from wells with open boreholes and, thus, may represent a mix of waters with different ages. All ages are regarded as apparent ages because they are based on an interpretation of measured concentrations of environmental tracers in groundwater (Plummer and others, 1993; Plummer and Busenberg, 2000). A detailed analysis of the estimates of tracer-based ages of groundwater done for the NAWQA program is described by Hinkle and others (2010).

\section{Quality Assurance and Quality Control of USGS NAWQA Samples}

Documented quality-assurance practices for the collection and analysis of water-quality data have been implemented for the NAWQA samples. The quality-control (QC) samples collected by the USGS NAWQA Program, which are used to assess the reliability of sample processing and analytical methods, included equipment blanks, field blanks, source-solution blanks, and replicate samples. In addition, field matrix spikes (FMSs) and laboratory matrix spikes (LMSs) were collected to assess the extent, if any, that variability, degradation, and matrix effects have on VOC and pesticide data.

\section{Blank Samples}

Blank samples were collected to determine the occurrence and magnitude of the contamination of the environmental sample during cleaning of the equipment; during collecting, processing, and transport; and during laboratory analysis (Mueller and Titus, 2005; Apodaca and others, 2006; Bender and others, 2011). Blank samples were collected and analyzed for nutrients ( $\mathrm{N}$ and $\mathrm{P}$ compounds), pesticides and volatile organic compounds, major ions, and trace elements. Results of analyses of inorganic and organic field-blank samples are summarized in table 3 . Concentrations of analytes detected in field-blank samples were compared to concentrations of analytes in the NAWQA environmental samples to determine the potential for contamination of the environmental samples. If the concentration of a constituent in the blank samples approaches or exceeds the concentration of the constituent in the environmental samples, then the environmental water-quality data could be biased by sampling contamination. No compounds were detected in any of the six blank samples collected for pesticide analysis. Concentrations of ammonia $\left(\mathrm{NH}_{3}\right)$, orthophosphate $\left(\mathrm{PO}_{4}\right)$, aluminum ( $\left.\mathrm{Al}\right)$, boron, copper $(\mathrm{Cu})$, lead $(\mathrm{Pb})$, zinc $(\mathrm{Zn})$, and toluene in at least one blank sample were greater than the smallest concentration reported for the environmental samples (table 3 ). Therefore, it may not be possible to distinguish between "true" aquifer conditions and sampling contamination at small concentrations for these constituents. However, relatively few or none of the other analytes were detected in the blank samples; therefore, equipment decontamination and sample-handling procedures adequately prevented positive bias of reported concentrations for nearly all constituents.

\section{Replicate Samples}

Replicate samples are two environmental samples collected sequentially to determine the variability of the data as a result of sampling and analytical procedures. The relative percentage difference $(R P D)$ between concentrations of paired replicate samples was calculated using the formula

$$
R P D=\frac{\text { Sample1 }- \text { Sample } 2}{\frac{\text { Sample1 }+ \text { Sample } 2}{2}} \times 100 .
$$

When there is no variability between the paired analyses, the $R P D$ is zero. The $R P D$ was not calculated if one or more of the paired samples was censored below the LRL or identified as estimated by the USGS NWQL.

Two to four pairs of sequential replicate samples were collected for the analysis of inorganic constituents. Sequential replicates are multiple samples collected as closely as possible to the same location but at different times (in this study, one set of samples right after the other, but with dedicated filters). The individual constituents with the largest $R P D$ s among the paired samples were nickel (71.4 percent), copper (70.3 percent), lead (45 percent), zinc ( 42.8 percent), aluminum ( 20.7 percent), cobalt (12.7 percent), and fluoride (9.95 percent). In most cases, the largest $R P D$ s were for constituents that were present in small concentrations. Small differences in concentrations, when concentrations themselves are small, can produce large RPDs. The nutrients and major ion replicates generally had lower $R P D$ s than did the trace-element replicates.

\section{Spiked Samples}

Matrix spike quality-control samples measure the bias caused by analyte degradation or sample matrix interference (Rowe and others, 2005; Martin and others, 2009; Martin and Eberle, 2011). The term "matrix" indicates that the spiked solution has been added to an environmental water sample. Groundwater is collected from the well and processed by use of standard operating procedures to produce two samples (Koterba and others, 1995). Spike solution is added to one of the two water samples, resulting in a spiked sampled and paired with an un-spiked environmental (or "background") sample (Rowe and others, 2005; Martin and others, 2009). Most of the pesticide and volatile organic compound matrix spikes were spiked at the field site (field matrix spikes). A few matrix spike samples were spiked by in the laboratory before analysis (laboratory matrix spikes). The amount of a pesticide or VOC measured (recovered) in a FMS or LMS sample is expressed as a percentage (percent recovery) of the known amount of the analyte added to the sample. The percent recovery is considered a primary measure of the performance of the analytical method (Row and others, 2005; Martin and others, 2009). FMSs measure the bias and variability of the analytical 
Table 3. Inorganic and organic constituents detected in blank samples collected by the National Water-Quality Assessment Program studies in New England crystalline rock aquifers, in New England, New Jersey, and New York, $1995-2000$.

[USGS NWIS, U.S. Geological Survey National Water Information System; N, nitrogen; P, phosphorus; E, estimated concentration; +, plus; <, less than; $\mathrm{mg} / \mathrm{L}$, milligrams per liter; $\mu \mathrm{g} / \mathrm{L}$, micrograms per liter. The following constituents were not detected in any blank samples: antimony, arsenic, barium, beryllium, bromide, cadmium, chloride, cobalt, fluoride, manganese, molybdenum, nitrite, phosphorus, silver, sulfate, thallium, uranium, and vanadium. No pesticide compounds were detected in any of the six blank samples. All inorganic blank samples were filtered through a single-use, 0.45 -micron capsule filter. Volatile organic compound blank samples were not filtered. Pesticide blank samples were filtered through a single use, 0.7-micron glass-fiber filter. Blank samples were analyzed by the U.S. Geological Survey National Water-Quality Laboratory in Denver, Colorado]

\begin{tabular}{|c|c|c|c|c|c|}
\hline Water-quality constituent & $\begin{array}{l}\text { USGS NWIS } \\
\text { parameter code }\end{array}$ & $\begin{array}{c}\text { Number of detections/ } \\
\text { number of blank samples }\end{array}$ & Units & $\begin{array}{c}\text { Maximum } \\
\text { concentration in } \\
\text { blank samples }\end{array}$ & $\begin{array}{c}\text { Minimum } \\
\text { concentration in } \\
\text { environmental samples }\end{array}$ \\
\hline \multicolumn{6}{|c|}{ Nutrients } \\
\hline Ammonia, as $\mathrm{N}$ & 00608 & $1 / 12$ & $\mathrm{mg} / \mathrm{L}$ & 0.02 & $<0.02$ \\
\hline Ammonia + organic nitrogen, as $\mathrm{N}$ & 00623 & $1 / 12$ & $\mathrm{mg} / \mathrm{L}$ & E.081 & $<0.1$ \\
\hline \multicolumn{6}{|c|}{ Major ions } \\
\hline Calcium & 00915 & $5 / 19$ & $\mathrm{mg} / \mathrm{L}$ & E.017 & 2.72 \\
\hline Magnesium & 00925 & $1 / 19$ & $\mathrm{mg} / \mathrm{L}$ & E.009 & 0.36 \\
\hline Sodium & 00930 & $6 / 19$ & $\mathrm{mg} / \mathrm{L}$ & 0.14 & 1.83 \\
\hline Aluminum & 01106 & $7 / 22$ & $\mu \mathrm{g} / \mathrm{L}$ & 9.28 & $<1$ \\
\hline Boron & 01020 & $8 / 24$ & $\mu \mathrm{g} / \mathrm{L}$ & 13.5 & $<12$ \\
\hline Chromium & 01030 & $4 / 22$ & $\mu \mathrm{g} / \mathrm{L}$ & E.75 & $<0.8$ \\
\hline Copper & 01040 & $3 / 22$ & $\mu \mathrm{g} / \mathrm{L}$ & 2.16 & $<1$ \\
\hline Lead & 01049 & $2 / 22$ & $\mu \mathrm{g} / \mathrm{L}$ & 20 & $<1$ \\
\hline Lithium & 01130 & $1 / 14$ & $\mu \mathrm{g} / \mathrm{L}$ & 0.47 & $<0.6$ \\
\hline Iron & 01046 & $1 / 19$ & $\mu \mathrm{g} / \mathrm{L}$ & E3 & $<10$ \\
\hline Nickel & 01065 & $1 / 22$ & $\mu \mathrm{g} / \mathrm{L}$ & 0.07 & $<1$ \\
\hline Selenium & 01145 & $1 / 22$ & $\mu \mathrm{g} / \mathrm{L}$ & E.40 & $<0.7$ \\
\hline \multicolumn{6}{|c|}{ Volatile organic compounds } \\
\hline Dichloromethane & 34423 & $1 / 19$ & $\mu \mathrm{g} / \mathrm{L}$ & E.014 & E.018 \\
\hline Ethylbenzene & 34371 & $1 / 19$ & $\mu \mathrm{g} / \mathrm{L}$ & E.01 & $<0.03$ \\
\hline Toluene & 34010 & $8 / 19$ & $\mu \mathrm{g} / \mathrm{L}$ & 0.13 & 0.006 \\
\hline$m$ - and $p$-xylene & 85795 & $1 / 17$ & $\mu \mathrm{g} / \mathrm{L}$ & E.03 & 0.02 \\
\hline$o$-xylene & 77135 & $1 / 17$ & $\mu \mathrm{g} / \mathrm{L}$ & E.01 & 0.055 \\
\hline
\end{tabular}


method plus any potential effects caused by (1) degradation of the organic compound during shipment to the laboratory and (2) interferences from other water-quality characteristic of the environmental sample, such as hydrogen sulfide. LMSs measure the bias and variability of the analytical method at a particular concentration. Rowe and others (2005) analyzed in detail all VOC spike matrix samples collected for the NAWQA Program from groundwater wells and surface-water sites for the period 1997 to 2001. Rowe and others (2005) reported that 87 percent of the individual VOC recoveries were within acceptable ranges and demonstrate that low VOC concentrations can routinely and accurately be measured by the analytical methods used by the NWQL. Martin and others (2009) and Martin and Eberle (2011) analyzed in detail all pesticide spike matrix samples collected for the NAWQA program from groundwater wells and surface-water sites for the period 1992 to 2010 to examine temporal changes in the recovery of 44 pesticide and 8 pesticide degradates.

\section{Data from USEPA SDWA Public-Supply Wells}

For the purpose of this study, water samples collected from public-supply wells for compliance with the USEPA SDWA Program (table 2), were selected using the following criteria: (1) wells were completed in crystalline bedrock, (2) water-quality data could be attributed to a single well, and
(3) the data are from untreated (and unfiltered) samples that represent the quality of the source aquifer. For each waterquality constituent and associated SDWA well, only the most recent value in the dataset was selected.

Using the above selection criteria, a total of 4,775 publicsupply wells (table 2) completed in crystalline rock in New England with at least one water-quality measurement for nitrate $\left(\mathrm{NO}_{3}\right)$, chloride $(\mathrm{Cl})$, fluoride $(\mathrm{F})$, sodium $(\mathrm{Na}), \mathrm{Mn}$, $\mathrm{Fe}, \mathrm{As}, \mathrm{U},{ }^{222}$ radon gas (radon), gross alpha-particle radioactivity (gross alpha), combined radium $\left({ }^{228} \mathrm{Ra}\right.$ plus $\left.{ }^{226} \mathrm{Ra}\right)$, or $\mathrm{M} t \mathrm{BE}$ were compiled for this study (table 4). Data on the physiochemical properties $\mathrm{pH}$ and specific conductance (SC) also were compiled. In New Hampshire, there were 2,067 public-supply bedrock wells with available water-quality data, followed by Maine with 1,185 wells, Vermont with 488 wells, Massachusetts with 455 wells, Rhode Island with 418 wells, and Connecticut with 162 wells (table 2). The number of samples of untreated groundwater analyzed for a particular constituent is greatest for $\mathrm{NO}_{3}$, and the constituent with the fewest number of samples is for $U$ (table 4). The number of samples analyzed for a particular constituent varies because the requirements for compliance monitoring depend on the contaminant being measured and the type of the community water system being monitored. Also, the requirements for the compilation of data from untreated samples may differ by State.

Table 4. Number of untreated, unfiltered water samples analyzed for selected water-quality properties and constituents, collected for the U.S. Environmental Protection Agency Safe Drinking Water Act Program from public-supply wells in New England crystalline rock aquifers, by State, 1997-2007.

[--, no data; Combined radium is equal to ${ }^{226}$ radium plus ${ }^{228}$ radium; Gross alpha, gross alpha-particle radioactivity; MtBE, methyl tert-butyl ether]

\begin{tabular}{|c|c|c|c|c|c|c|c|}
\hline \multirow{2}{*}{$\begin{array}{l}\text { Water-quality physical } \\
\text { property or constituent }\end{array}$} & \multicolumn{6}{|c|}{ Number of untreated water samples } & \multirow{2}{*}{ Total for study } \\
\hline & Connecticut & Massachusetts & Maine & New Hampshire & Rhode Island & Vermont & \\
\hline $\mathrm{pH}$ & 161 & -- & 272 & 1,287 & 125 & 63 & 1,908 \\
\hline Specific conductance & 14 & -- & 22 & 636 & 20 & 12 & 704 \\
\hline Nitrate & 154 & 441 & 1,169 & 2,014 & 414 & 472 & 4,664 \\
\hline Chloride & 147 & -- & 342 & 1,121 & 66 & 74 & 1,750 \\
\hline Sodium & 150 & 412 & 389 & 1,261 & 124 & 68 & 2,404 \\
\hline Fluoride & 141 & 211 & 399 & 997 & 189 & 113 & 2,050 \\
\hline Iron & 21 & 89 & 403 & 821 & 66 & 114 & 1,514 \\
\hline Manganese & 14 & 90 & 403 & 905 & 67 & 163 & 1,642 \\
\hline Arsenic & 144 & 242 & 414 & 781 & 190 & 166 & 1,937 \\
\hline Uranium & 58 & 30 & 27 & 317 & 7 & -- & 439 \\
\hline Combined radium & 59 & 95 & 26 & 228 & 44 & 56 & 508 \\
\hline Gross alpha & 59 & 195 & 43 & 472 & 66 & -- & 835 \\
\hline${ }^{222}$ Radon & -- & 45 & 91 & 637 & 57 & 1 & 831 \\
\hline $\mathrm{M} t \mathrm{BE}$ & -- & 298 & 340 & 215 & 220 & 111 & 1,184 \\
\hline
\end{tabular}


About 18 percent of the 4,775 public-supply wells used in this study are classified as community (COM) water systems (for example, municipalities) (fig. 2A; table 2). Community water systems serve a minimum of 25 persons year round or have at least 15 service connections used by residents all year. Twenty-three percent of the public-supply wells are nontransient noncommunity (NTNC) water systems (for example, schools) (fig. 2B; table 2). NTNC systems serve 25 persons or more at least 6 months of the year. Nearly 60 percent of the public-supply wells are transient, noncommunity (TNC) water systems (for example, restaurants or campgrounds), defined as serving 25 different persons at least 60 days per year (fig. 2C; table 2).

The SDWA Program for each New England State requires the use of methods of analysis approved by the USEPA (at http://water.epa.gov/scitech/drinkingwater/labcert/methods_ index.cfm). State certification programs regularly audit their certified (accredited) laboratories to make certain that laboratories meet the performance criteria for the constituents they are certified to analyze. Of the constituents used in this report, only $\mathrm{pH}$ is exempt from laboratory certification; nonlaboratory personnel are permitted to collect $\mathrm{pH}$ data. Each State's certified laboratories supply the containers, preservative, and trip blanks for sampling and certify that these sampling supplies are free of contaminants at the laboratory detection level for each analyte. In Rhode Island, State personnel collected the compliance samples from the community water systems until January 2008, when the responsibility was transferred to the regulated water systems. In all other New England States, personnel of the regulated water systems were responsible for collecting and submitting water samples to USEPA-certified laboratories for analysis. The USEPA Region 1 reviews and retains the acceptance limits for each certified laboratory for precision and accuracy, and the USEPA requires mandatory quality-control measures. The drinking-water program for each New England State retains sample collection sheets, custody forms, all laboratory tracking data, worksheets, and other raw data.

The USEPA and (or) State regulatory office determine locations for, and frequency of, sampling of regulated water systems. Except for New Hampshire, all New England State drinking-water programs use the sampling guidance found in "New England States Sample Collection and Preservation Guidance Manual For Drinking Water" available at http://www.epa.gov/region1/lab/qa/pdfs/NE-States-SampleCollection-Manual.pdf. New Hampshire's drinking-water sampling guidelines are available at http://des.nh.gov/ organization/commissioner/pip/publications/co/documents/ r-co-01-5.pdf.

\section{Treatment and Statistical Analysis of Water- Quality Data}

Because laboratory analytical methods for many constituents improved during the study period, the LRLs did not remain the same for most studied water-quality constituents; this difference in LRLs can affect their occurrence statistics. To remove the effect of variable LRLs for the pesticide compounds from the NAWQA samples, occurrence rates were compared using common assessment levels of 0.001 and $0.01 \mu \mathrm{g} / \mathrm{L}$. The occurrence rates of the VOCs from the NAWQA samples were compared using common assessment levels of $0.02,0.2$, and $1 \mu \mathrm{g} / \mathrm{L}$. Until 1996, VOC analytical results, including those reported for the CONN study, were reported by the USGS NWQL at a common LRL of $0.2 \mu \mathrm{g} / \mathrm{L}$. After 1996, VOC analytical results, including those reported for the NECB and LINJ studies, were analyzed using a method (Childress and others, 1999) that reported variable LRLs that were 10 to 100 times lower than for the CONN study.

Some sections of this report combine water-quality data from the SDWA and NAWQA Programs for analysis. However, many of the 14 water-quality constituents compiled from the SDWA program had LRLs greater than the LRLs from the NAWQA program. Therefore, it was necessary to set the censoring level of the data to the lowest common reporting level when analyzing data with different reporting levels (Helsel and Hirsch, 2002; Helsel, 2005). Censored values and detected values reported below the common LRL were re-censored to the common LRL. For example, As data with reported values of $<1,<2,1.5,4$, and $<5$ were re-censored to $<5$ in order to make comparisons valid. Censored values reported above the common LRL were removed from analysis.

The Spearman correlation was used to assess the magnitude and direction of the association between two variables in a dataset (Helsel and Hirsch, 1992). The water-quality data presented in this report were correlated with each other and with explanatory variables, such as land use, population density, and well depth. Where available, the water-quality data also were analyzed to determine if there were differences in concentrations between domestic and public-supply wells. In this report, a probability value ( $P$-value) of less than 0.05 indicates that there is a significant difference between two groups of data. For categorical explanatory variables, the nonparametric Tukey's test was conducted on the means of the ranks to compare concentrations among groups (Helsel and Hirsch, 1992).

\section{Explanatory Variables}

Harte and others (2008) suggest that a variety of extrinsic factors (variables that can change over time) and intrinsic factors (variables that do not change over time) can affect groundwater quality. Examples of extrinsic factors studied that can change over time include land use, land cover, population density, water-quality data, and water levels. Intrinsic factors studied that do not change over time include well-construction properties (such as well depth) and the geology in the vicinity of the sampled well. 


\section{Categories of Land Use and Land Cover}

For this study, the percentage of land use and land cover for each major category (agriculture, developed, and undeveloped) within an area surrounding each sampled well and measuring $500 \mathrm{~m}$ [1,640 feet (ft)] in radius was assessed on the basis of the 2001 National Land Cover dataset (U.S. Geological Survey, 2006). Agricultural land uses in this study area include grasslands, pasture/hay, and cultivated crop areas. Developed (or "urban") land uses include areas classified as open space, low intensity, medium intensity, and high intensity. The term "intensity" refers to the percent of impervious surfaces (such as roads or parking lots) within an area. Low intensity developed lands have 20 to less than 50 percent impervious surfaces, medium intensity developed lands have 50 to 79 percent impervious surfaces, and high intensity developed lands have greater than 79 percent impervious surfaces. Undeveloped lands have less than 20 percent impervious surfaces and include open water; barren and shrub lands; deciduous, evergreen, and mixed forests; woody wetlands; and emergent herbaceous wetlands.

Undeveloped lands were the dominant land use within $500-\mathrm{m}$ radius area surrounding most of the wells (fig. 3A). The medians of the percentage values of undeveloped lands within 500 -m radius for public-supply and domestic wells in New England are 70 and 79 percent, respectively; and for the New Jersey and New York (NJ-NY) domestic wells, the median is 75 percent (fig. 3A). The medians of the percentage values of developed lands within 500-m radius for the public-supply and domestic wells in New England are 18 and 11 percent, respectively; and for the NJ-NY domestic wells, the median is 17 percent (fig. 3B). The medians of the percentage values of agricultural lands within 500-m radius for the public-supply and domestic wells in New England are 6.6 and 7.5 percent, respectively; and for or the NJ-NY domestic wells, the median is 1.4 percent (fig. 3C).

On the basis of the distribution of percentages for the three major land uses within the 500-m radius of the sampled wells, each well was assigned to one of four categories:

(1) agricultural land use (greater than 15 percent agricultural lands and 5 percent or less of developed lands), (2) developed land use (greater than 25 percent of developed (or urbanized) lands and 15 percent or less of agricultural lands), (3) undeveloped land use (85 percent or greater undeveloped lands) and (4) mixed land use (no dominant land use) (table 5). Forty-two percent of all the sampled wells were in the mixed category,
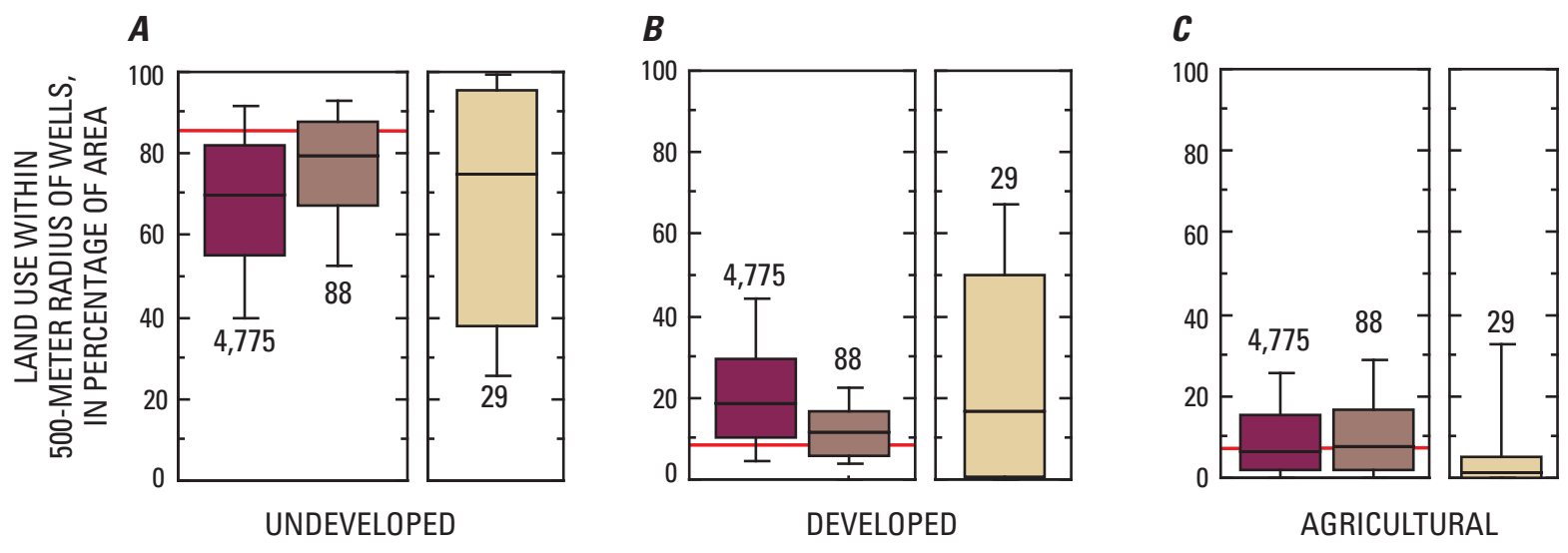

\section{EXPLANATION}
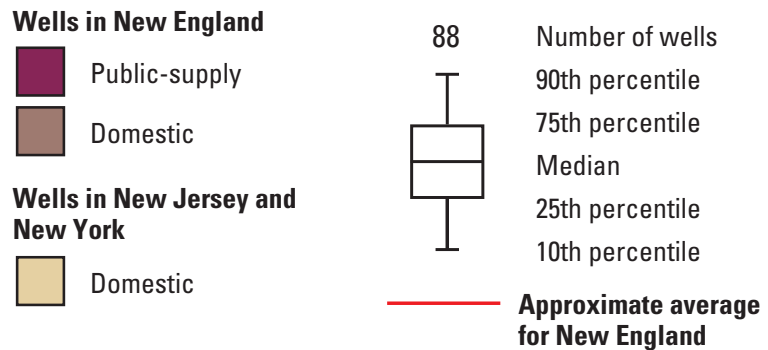

Figure 3. Distributions of $A$, undeveloped, $B$, developed, and $C$, agricultural land uses within 500-meter radius of the public-supply and domestic wells, by percentage of area, in New England crystalline rock aquifers for the year 2001. See table 5 for the distribution of sampled wells on the basis of categories of land use. 


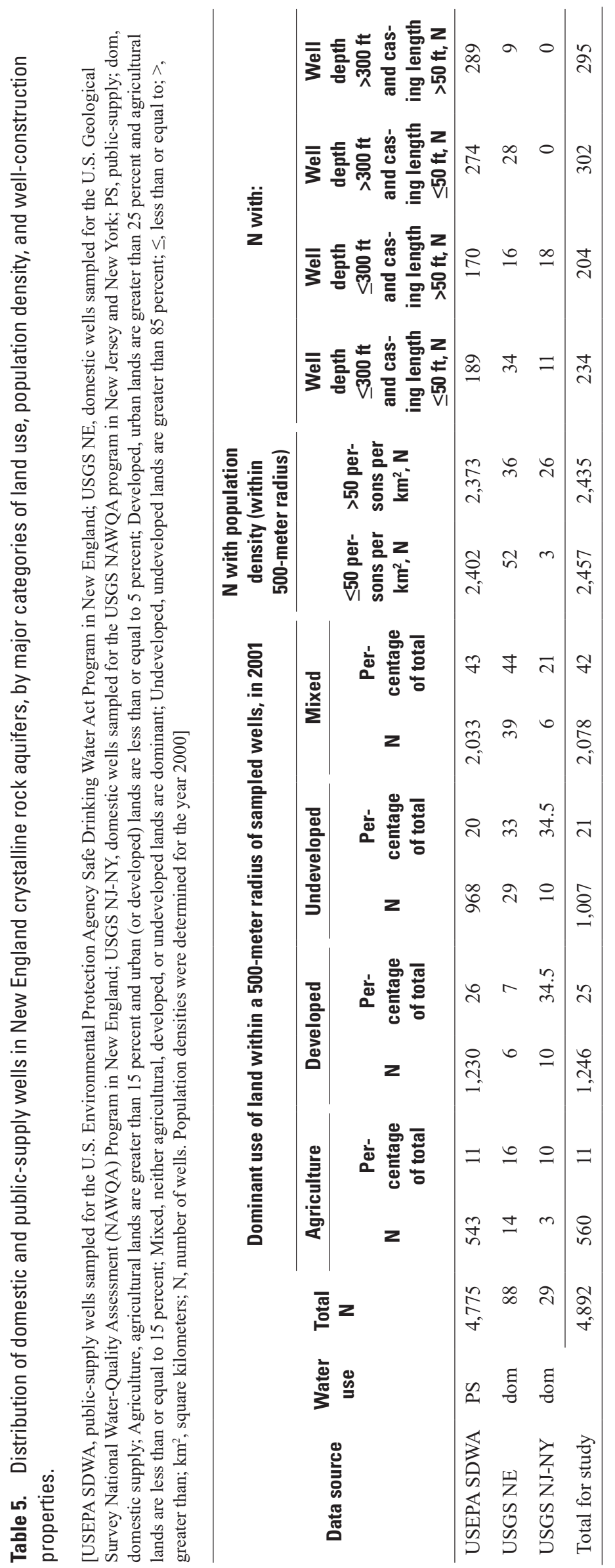


21 percent were in the undeveloped category, 25 percent were in the developed category, and 11 percent were in the agricultural category (table 5). Small areas of agricultural and residential lands are scattered throughout the New England region (Harte and others, 2008); the high proportion of the sampled wells in the mixed land-use category reflects this feature.

\section{Categories of Population Density}

The average population density in 2000 for New England was 85 persons per square kilometer (persons $/ \mathrm{km}^{2}$ ) (U.S. Bureau of the Census, 2001). The population densities in 2000 within a 500-m radius area surrounding the public-supply wells were mostly (10th to 90th percentile) in the range of 7 to 224 persons $/ \mathrm{km}^{2}$; the median population density was 49 persons $/ \mathrm{km}^{2}$ (fig. 4). The population densities in 2000 within a 500-m radius area surrounding the domestic wells in New England were mostly in the range of 7 to 170 persons/ $\mathrm{km}^{2}$; the median population density was 34 persons $/ \mathrm{km}^{2}$ (fig. 4).

The average population density in 2000 for New Jersey was 373 persons $/ \mathrm{km}^{2}$ (U.S. Bureau of the Census, 2001). Twenty-six of the 29 NJ-NY domestic wells are clustered in a small area of crystalline rock in the higher elevation areas (the "Highlands") of northern New Jersey; the remaining 3 domestic wells are located across the State border in southeastern New York (fig. 1). The population densities in 2000 within a 500-m radius area surrounding the NJ-NY domestic wells were mostly in the range of 14 to 398 persons $/ \mathrm{km}^{2}$; the median population density was 117 persons $/ \mathrm{km}^{2}$ (fig. 4).
Two population density categories were created to allow for nearly equal distribution of wells based on a demarcation point of 50 persons $/ \mathrm{km}^{2}$ (table 5). However, since the $29 \mathrm{NJ}-\mathrm{NY}$ domestic wells are in areas of significantly higher population densities than the wells in New England, 26 of these wells are in the higher population density category; the remaining 3 wells are in the lower population density category (table 5).

\section{Categories of Well Depth and Casing Length}

All wells in this report were generally constructed to similar specifications, using predominantly 6 -inch $(0.15-\mathrm{m})$ diameter steel casing (table 6). Casings are typically installed through the unconsolidated glacial sediments and driven into the underlying bedrock for a short distance. Groundwater enters the wells through fractures that intersect the open boreholes. The public-supply wells are generally deeper in total depth (median is $300 \mathrm{ft}$ ) than the domestic wells (median is $235 \mathrm{ft}$ ); and the bottom of the well casings (casing length) are at deeper depths (median is $50 \mathrm{ft}$ ) than the domestic wells (median is $40 \mathrm{ft}$ ) (table 6). Since there is little capacity for groundwater storage in crystalline rock, public-supply wells may be installed at deeper depths than domestic wells to increase borehole storage capacity or to intercept additional water-bearing fractures to increase well yield.

A total of 1,035 public-supply and domestic wells have information on both well depth and casing length. For these wells, the median well depth was $300 \mathrm{ft}$ and the median casing length was $50 \mathrm{ft}$. On the basis of these median values, each well was assigned to one of 4 categories: (1) well depth

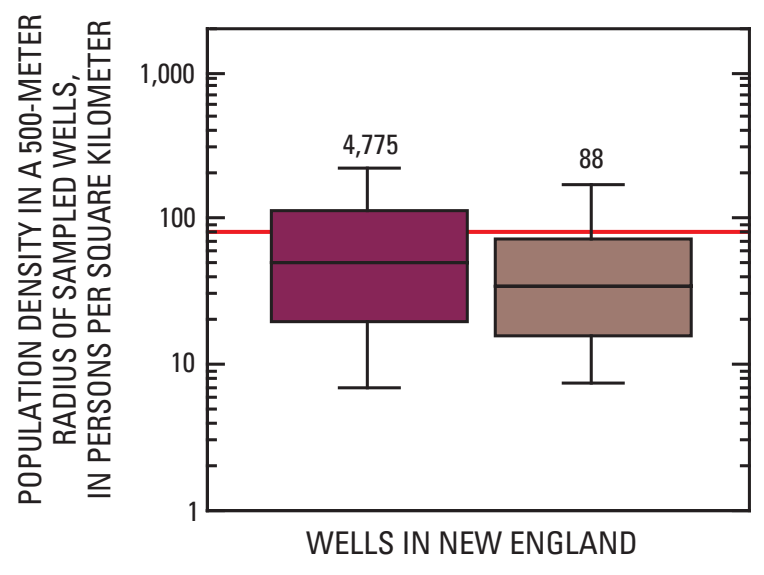

PUBLIC SUPPLY DOMESTIC
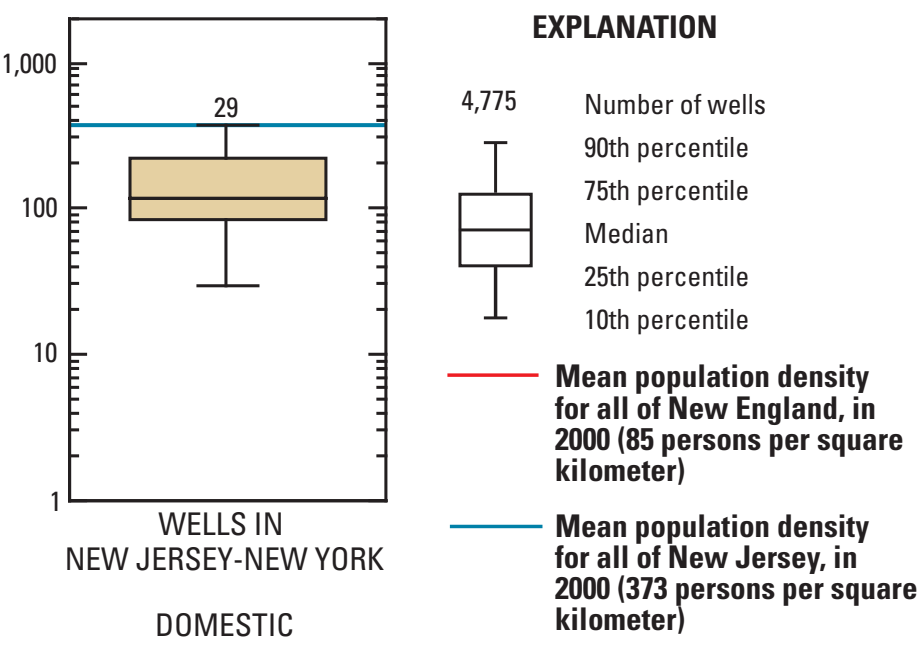

Figure 4. Distribution of population densities, by persons per square kilometer, in a 500-meter radius of the public-supply and domestic wells in New England crystalline rock aquifers for the year 2000. See table 5 for the distribution of sampled wells on the basis of categories of population density. 
Table 6. Summary statistics for selected well-construction properties of the domestic and public-supply wells in New England crystalline rock aquifers, 1995-2007.

[N, number of wells; Min, minimum; Max, maximum; USGS NAWQA, domestic bedrock wells sampled for the U.S. Geological Survey National WaterQuality Assessment (NAWQA) Program in New England, New Jersey and New York; USEPA SDWA, public-supply bedrock wells sampled for the U.S. Environmental Protection Agency Safe Drinking Water Act Program in New England]

\begin{tabular}{|c|c|c|c|c|c|c|c|c|c|c|}
\hline \multirow{2}{*}{ Data source } & \multirow{2}{*}{$\mathbf{N}$} & \multirow{2}{*}{ Min } & \multicolumn{7}{|c|}{ Percentiles } & \multirow{2}{*}{ Max } \\
\hline & & & 5th & 10th & 25th & 50th & 75th & 90th & 95th & \\
\hline \multicolumn{11}{|c|}{ Well casing diameter, in inches } \\
\hline USGS NAWQA & 117 & 6 & 6 & 6 & 6 & 6 & 6 & 6 & 6 & 8 \\
\hline USEPA SDWA & 114 & 2 & 6 & 6 & 6 & 6 & 6 & 6 & 8 & 12 \\
\hline \multicolumn{11}{|c|}{ Well depth, in feet } \\
\hline USGS NAWQA & 117 & 41 & 103 & 128 & 180 & 235 & 320 & 500 & 555 & 705 \\
\hline USEPA SDWA & 2,213 & 12 & 100 & 125 & 200 & 300 & 465 & 630 & 750 & 1,350 \\
\hline \multicolumn{11}{|c|}{ Depth to bottom of well casing, in feet } \\
\hline USGS NAWQA & 116 & 8 & 18 & 20 & 21.5 & 40 & 62.5 & 97 & 127 & 165 \\
\hline USEPA SDWA & 922 & 3 & 19 & 20 & 32 & 50 & 82 & 134 & 161 & 600 \\
\hline \multicolumn{11}{|c|}{ Water level, in feet below land surface } \\
\hline USGS NAWQA $^{1}$ & 103 & 0 & 1.16 & 2.7 & 8.17 & 20.92 & 36.18 & 55.15 & 60 & 95.5 \\
\hline USEPA SDWA & 143 & 0 & 3 & 5 & 13 & 24 & 50 & 90 & 150 & 425 \\
\hline
\end{tabular}

${ }^{1}$ Groundwater naturally flowed out of top of well casing in two of the domestic wells.

$\leq 300 \mathrm{ft}$ and casing length $\leq 50$ (23 percent); (2) well depth $\leq 300 \mathrm{ft}$ and casing length $>50 \mathrm{ft}$ (20 percent); (3) well depth $>300 \mathrm{ft}$ and casing length $\leq 50 \mathrm{ft}$ ( 28 percent); and (4), well depth $>300 \mathrm{ft}$ and casing length $>50 \mathrm{ft}$ ( 28 percent; table 5). In this study, the shallow wells $(\leq 300 \mathrm{ft})$ with short casing lengths $(\leq 50 \mathrm{ft})$ are more likely to intersect water-bearing fractures at shallower depths than the deeper wells $(>300 \mathrm{ft})$ with longer casing lengths $(>50 \mathrm{ft})$.

\section{Major Lithology Categories and Lithology Groups}

Bedrock lithology and other bedrock geologic features are known to be among the important factors that affect the chemical quality, residence time, and direction of flow of groundwater in New England crystalline rock (Robinson, 1997; Robinson and others, 2002; Montgomery and others, 2002; Robinson and Kapo, 2003), and these geologic features are a critical component of the framework design (Harte and others, 2008). The lithology and geochemistry of bedrock in the study area is complex and extremely variable. More than 1,200 individual bedrock geologic units (sometimes referred to as "bedrock formations") have been mapped collectively on state bedrock geologic maps (Robinson and Kapo, 2003). These geologic units have been mapped by a time-stratigraphic strategy and by rock type (dominant mineralogy and fabric). Rock weathering studies have shown that carbonate and sulfide minerals in the rocks are highly reactive in water and can have a disproportionately large effect on groundwater quality (Goldich, 1938; White and Brantley, 1995). Thus, Robinson and Kapo (2003) re-classified these bedrock geologic units into 37 lithogeochemical groups for the New England region based on the bedrock unit's minerals and texture; presence of carbonate, graphite, and sulfide minerals; depositional setting (such as restricted deposition within faultbounded sedimentary basins of Mississippian or younger age); and for some of the granitic units, mineralogy and magma chemistry. For this study, the 37 lithogeochemical groups were further simplified into three major lithology categories - felsic igneous rocks, mafic igneous and metamorphic rocks, and metasedimentary rocks - and nine lithology groups with broadly generalized geochemical and mineralogical characteristics (table 7).

The felsic igneous rocks category, consisting primarily of granitic and related plutonic rocks, covers about 25 percent of the study area (fig. 5A; table 7). The granitic and related plutonic rocks were subdivided into three lithology groups on the basis of major element chemistry and mineralogy: alkali granite $\left(\mathrm{I}_{\mathrm{a}}\right)$, metaluminous granite $\left(\mathrm{I}_{\mathrm{m}}\right)$, and peraluminous granite $\left(\mathrm{I}_{\mathrm{p}}\right)$. The alkali granite group $\left(\mathrm{I}_{\mathrm{a}}\right)$ of rocks contains a higher concentration of alkalis (calcium, sodium, and potassium) than needed to produce feldspars, resulting in minerals composed of alkali-rich iron-magnesium (Fe$\mathrm{Mg}$ ) silicates, such as biotite, sodic amphiboles, nepheline, pyroxene, and biotite. Syenite, monzosyenite, and monxonite rocks also are members of the $I_{a}$ group (table 7 ). $I_{a}$ rocks 
Study Design

17

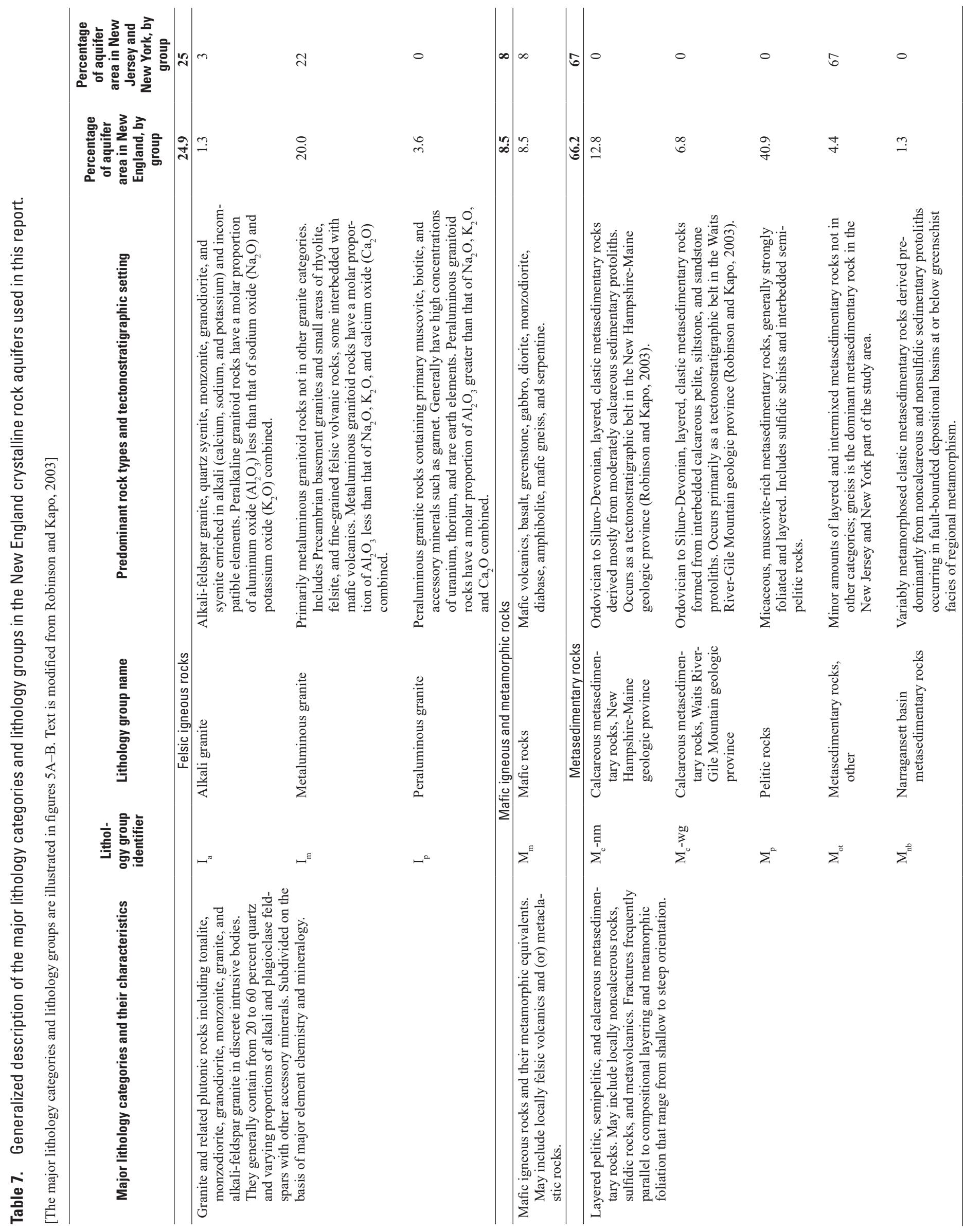




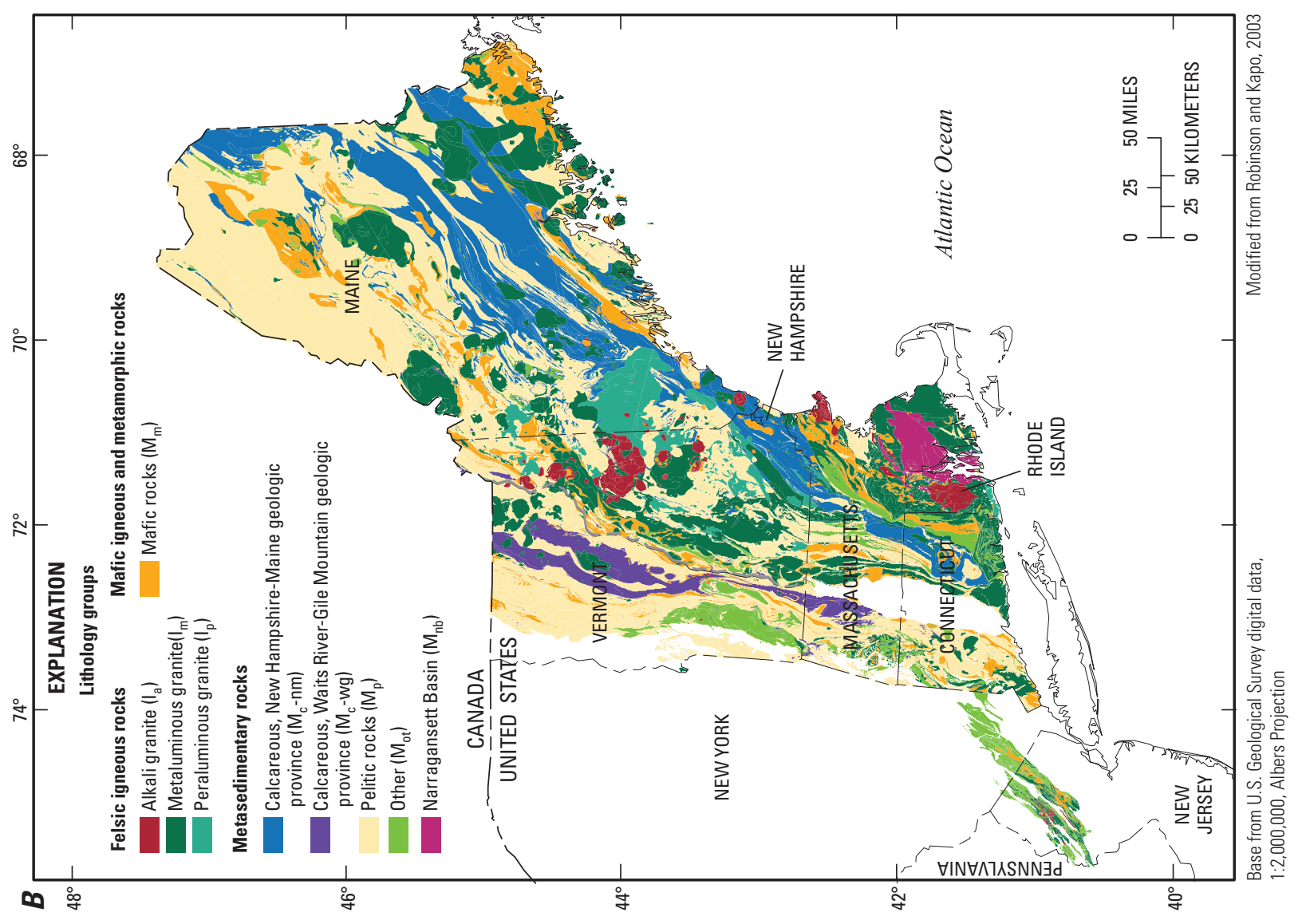

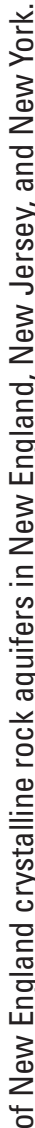

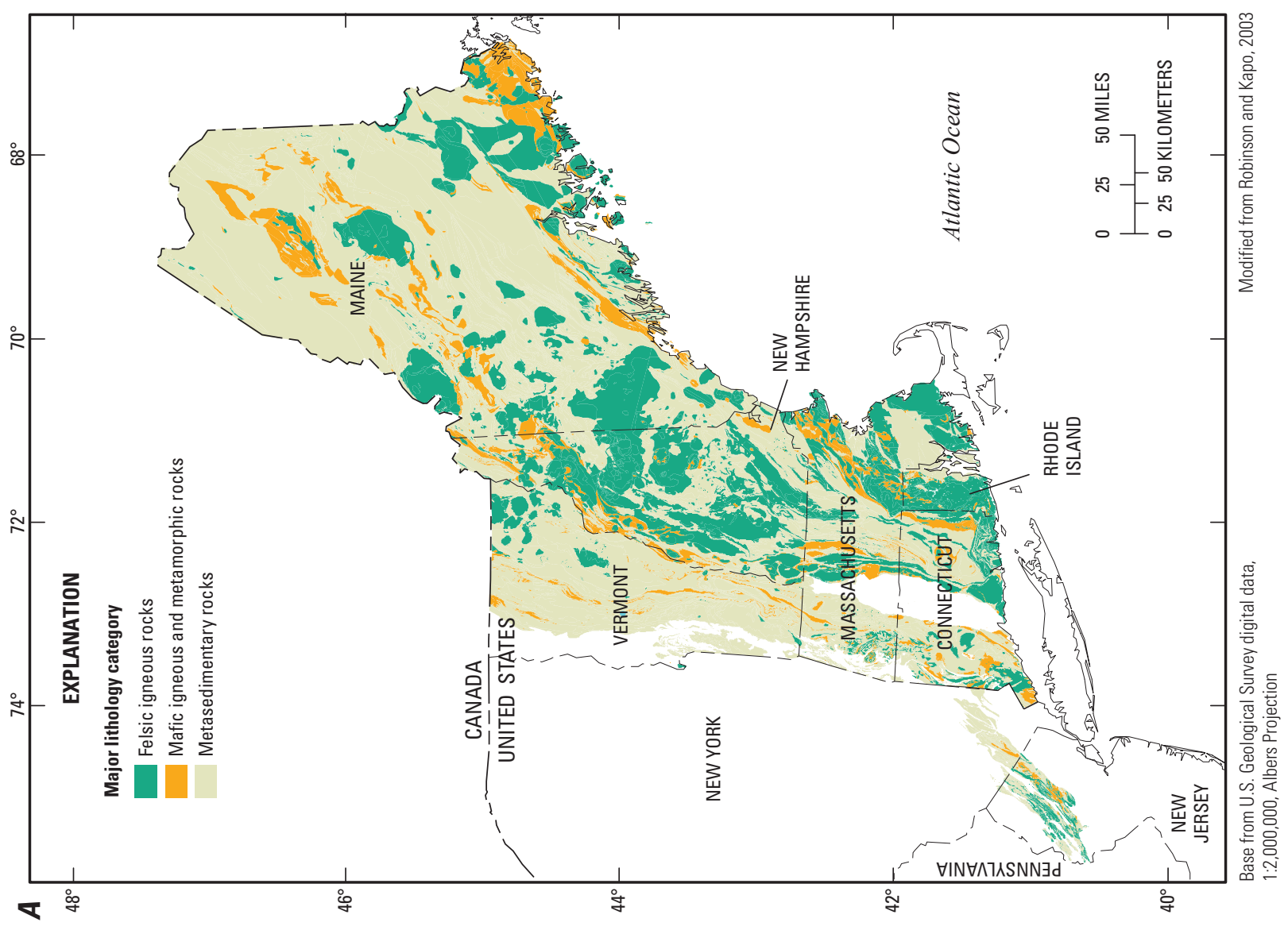

$\stackrel{2}{\circ}$

흥 흥

항 항

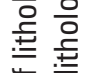

逭

등 क्ष

\& 흥

흥 屯

离 긍

흥음

응 프

플 음

흘

品

등

들 흘

올

을 웡

牙

뜬

힘

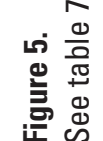


compose less than 3 percent of NECR aquifers, primarily in the White Mountains region of New Hampshire and central Rhode Island (fig. 5B). The metaluminous granite group $\left(\mathrm{I}_{\mathrm{m}}\right)$ of rocks has a near equal balance of alkalis and aluminum to generate feldspar with biotite, hornblende, and epidote as typical accessory minerals. $\mathrm{I}_{\mathrm{m}}$ rocks compose about 20 percent of NECR aquifers throughout the study area in New England and in New Jersey and New York (fig. 5B). The peraluminous granite group $\left(\mathrm{I}_{\mathrm{p}}\right)$ of rocks has more aluminum than can be incorporated in feldspars, and major and accessory minerals in these rocks include muscovite (with or without biotite), garnet, topaz, and Al-silicates (such as andalusite, kyanite, or sillimanite) (table 7). I rocks compose about 3.6 percent of NECR aquifers. The largest area of $I_{p}$ rocks is in west-central Maine near the New Hampshire border (fig. 5B).

Mafic igneous and metamorphic $\left(\mathrm{M}_{\mathrm{m}}\right)$ rocks are generally rich in magnesium and ferrous iron and low in silica (generally $<45$ percent). Basalt, mafic volcanics, greenstone, gabbro, diorite, monzodiorite, diabase, amphibolite, mafic gneiss, and serpentine rocks are members of the $M_{m}$ lithology group. $M_{m}$ rocks compose about 8.5 percent of NECR aquifers, mostly in narrow northeast-trending belts and isolated intrusive bodies northeast in the study area (table 7; figs. 5A-B).

Metasedimentary rocks, the most dominant lithology category in the study area, compose about 66 percent of NECR aquifers (table 7; fig. 5A). The largest lithology group in this category is composed of pelitic $\left(\mathrm{M}_{\mathrm{p}}\right)$ rocks. Some of the more common $\mathrm{M}_{\mathrm{p}}$ rocks include slate, phyllite, and schist, sometimes interlayered with lesser amounts of other types of rock (table 7). $M_{p}$ rocks compose nearly 41 percent of NECR aquifers, mostly in northern New England and westernmost Connecticut and Massachusetts (fig. 5B). The second largest group of metasedimentary rocks includes the clastic metamorphic rocks derived predominantly from moderately calcareous sedimentary protoliths. In this study, these calcareous metasedimentary rocks were further separated into two distinct geologic provinces (or tectonostratigraphic zones): the New Hampshire-Maine geologic province ( $\mathrm{M}_{\mathrm{c}}-\mathrm{nm}$ group) and the Waits River-Gile Mountain geologic province ( $\mathrm{M}_{\mathrm{c}}$-wg group). The $\mathrm{M}_{\mathrm{c}}-\mathrm{nm}$ lithology group lies in a north-northeast trending belt of rocks within eastern New England, primarily in New Hampshire and Maine (fig. 5B). The $\mathrm{M}_{\mathrm{c}}$-wg lithology group is predominately in west-central Massachusetts and eastern Vermont near the New Hampshire border in a south-north belt of rocks (fig. 5B). Combined, the $\mathrm{M}_{\mathrm{c}}-\mathrm{nm}$ and $\mathrm{M}_{\mathrm{c}}-\mathrm{wg}$ lithology groups compose 19.6 percent of NECR aquifers (table 7).

The "other" metasedimentary rocks $\left(\mathrm{M}_{\mathrm{ot}}\right)$ lithology group composes 4.4 percent of NECR aquifers and consists of metamorphosed metasedimentary rocks that do not fit into the other metasedimentary rock lithology groups (table 7). $\mathrm{M}_{\mathrm{ot}}$ rocks, consisting primarily of oligoclase- and feldspar-gneiss, dominate the area (67 percent) of crystalline rock in the LINJ part of the study area (fig. 5B). The Narragansett Basin metasedimentary $\left(\mathrm{M}_{\mathrm{nb}}\right)$ rocks, in eastern Rhode Island and southeastern Massachusetts, compose 1.3 percent of NECR aquifers (fig. 5B). The $\mathrm{M}_{\mathrm{nb}}$ lithology group consists of layered sedimentary rocks that have been partially metamorphosed and, thus, are considered part of NECR aquifers.

\section{Quality of Water in New England Crystalline Rock Aquifers}

The physiochemical properties and chemical data on domestic and public-supply wells in NECR aquifers are discussed in this section. A statistical summary for selected physiochemical properties of and inorganic constituents in water samples collected by the USGS NAWQA Program from 88 domestic wells in New England is provided in appendix 1, and from 29 domestic wells in New Jersey and New York is provided in appendix 2. A statistical summary for 2 physiochemical properties and 12 water-quality constituents in water samples collected for the USEPA SDWA Program from 4,775 public-supply wells in New England is provided in appendix 3. A statistical summary for 4 physiochemical properties and 24 water-quality constituents from all wells studied is presented in table 8 .

\section{Dissolved Gases and Apparent Age of Groundwater}

Dissolved, atmospheric-gas samples were collected from 56 domestic wells for the NECB NAWQA study to aid in the interpretation of the CFC-isotope method for age-dating groundwater (Plummer and others, 1993; Plummer and Busenberg, 2000). Gas concentrations in $\mathrm{mg} / \mathrm{L}$ ranged from $<0.001$ to 15.5 for methane $\left(\mathrm{CH}_{4}\right), 17.6$ to 29.8 for nitrogen (gas; $\left.\mathrm{N}_{2}\right) 0.2$ to 135 for carbon dioxide $\left(\mathrm{CO}_{2}\right)$, and 0.53 to 0.9 for argon (Ar) (appendix 1). Much of the groundwater from NECR aquifers is young (less than 50 years since date of recharge). The apparent residence time (age) of groundwater (calculated as the sample date minus the estimated year of recharge) in samples from 55 domestic wells ranged from 3 to more than 51 years, with a median value of 25 years (appendix 1).

Two samples had unusually high $\mathrm{CH}_{4}$ concentrations ( 8.9 and $15.5 \mathrm{mg} / \mathrm{L}$ ). Methane is highly flammable in confined spaces, and high concentrations of $\mathrm{CH}_{4}$ dissolved in bedrock groundwater have been documented in isolated areas in New Hampshire and Massachusetts (David Wunsch, New Hampshire State Geologist, written commun., 2004; Pierce and others, 2007). Degnan and others (2008) investigated in detail, using borehole-geophysical logs and other tools, the surrounding geology of the domestic well (in Wolfeboro, N.H.) in this study that had the highest $\mathrm{CH}_{4}$ concentration $(15.5 \mathrm{mg} / \mathrm{L})$. Results from the geophysical logs indicated that the geologic units exposed within the borehole of this well consist largely of foliated tonalite that is cut by abundant dikes of granite and pegmatite (Degnan and others, 2008). 


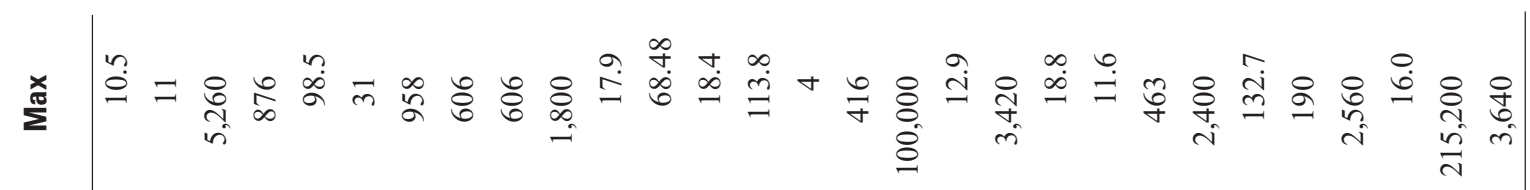

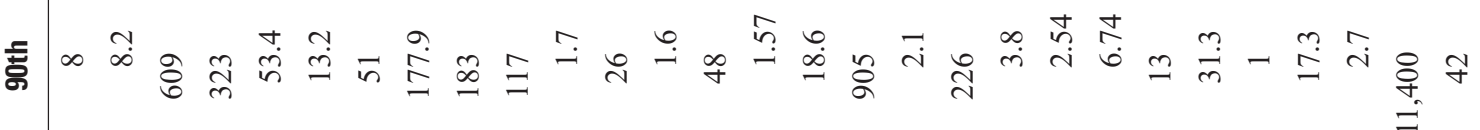

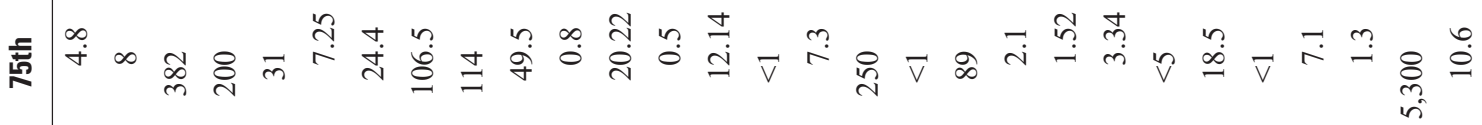

竞

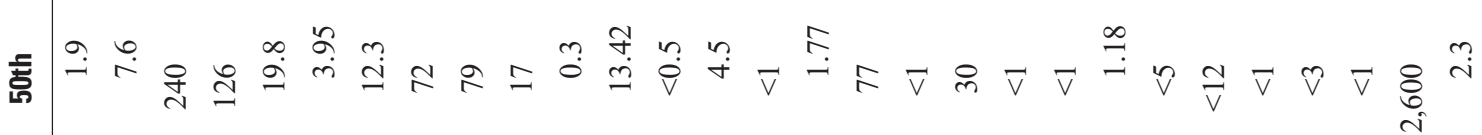

党

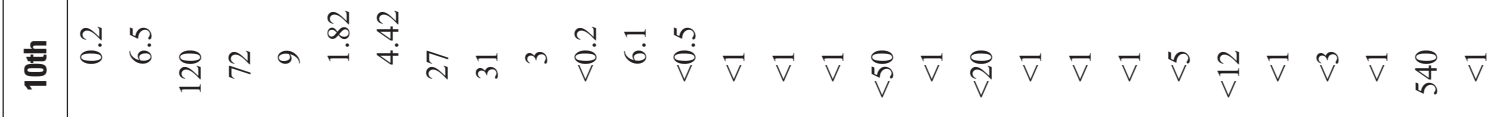

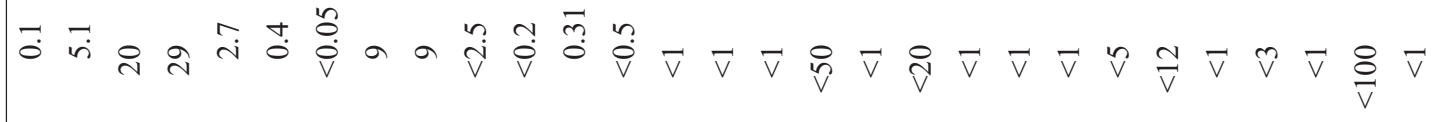

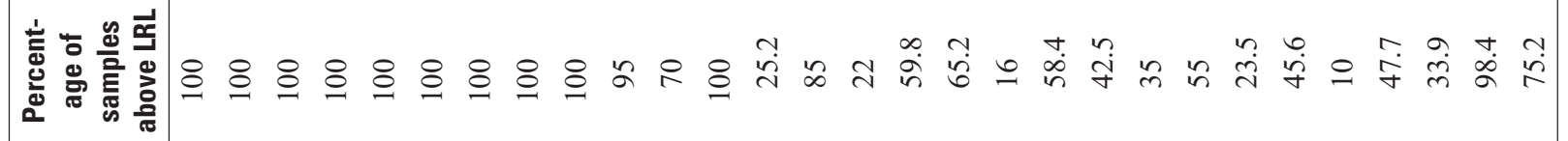

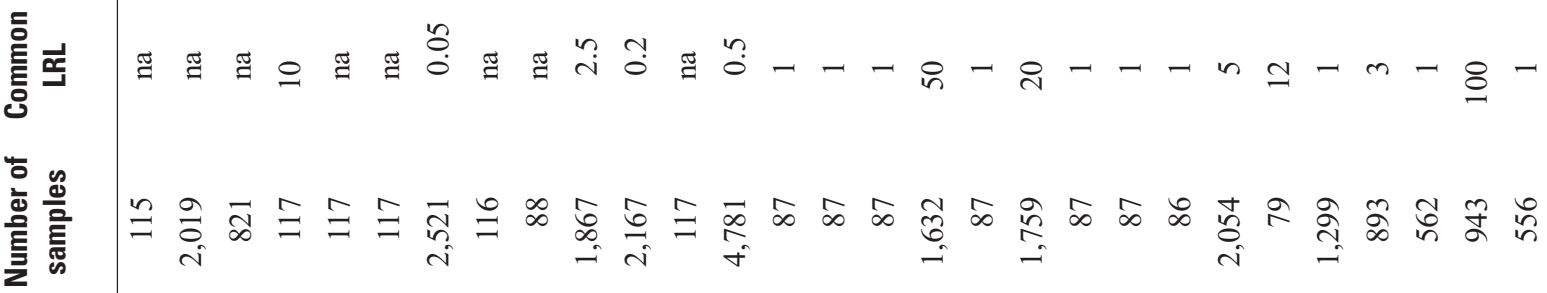

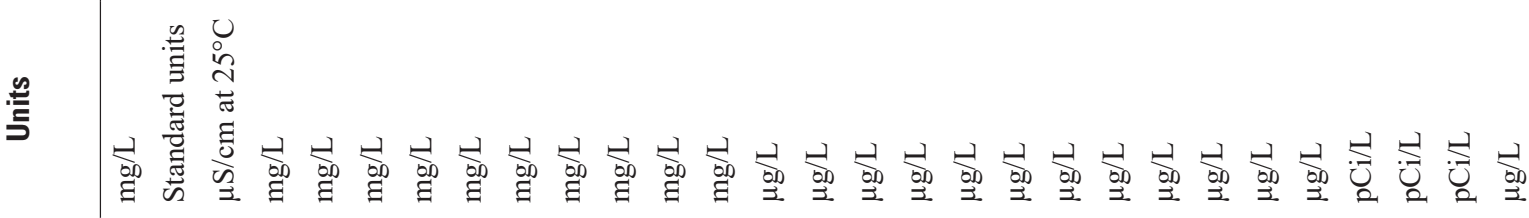

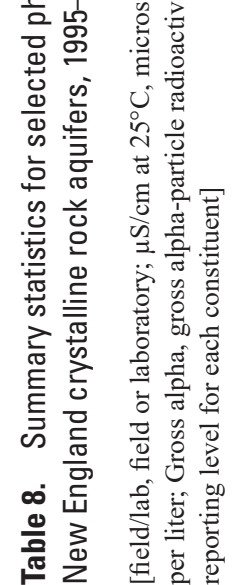

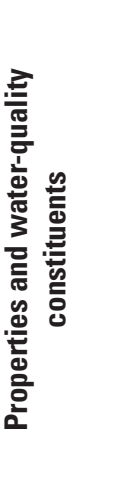

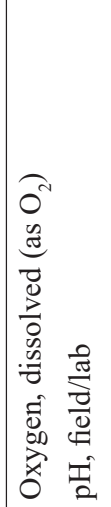
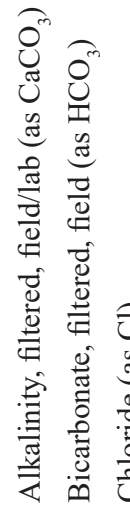

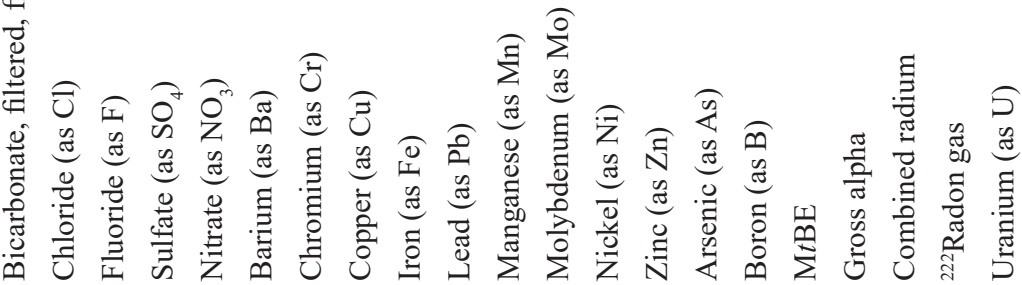




\section{Physiochemical Properties}

Dissolved oxygen (DO), $\mathrm{pH}$, specific conductance, alkalinity, turbidity, and water temperature are physiochemical properties of water that can affect the mobility of trace elements and other contaminants in groundwater. These properties vary in crystalline rock aquifers depending on precipitation chemistry, properties and chemical characteristics of soil and of aquifer materials, fracture flow (such as whether water being pumped originates from discharge or recharge zones), residence time of groundwater, and inputs from anthropogenic contaminants.

Dissolved oxygen concentrations in 115 domestic well samples were mostly in the range of 0.2 to $8 \mathrm{mg} / \mathrm{L}$; the median concentration was $1.9 \mathrm{mg} / \mathrm{L}$ (table 8). Dissolved oxygen in groundwater originates primarily from the atmosphere at the time of recharge and is highly reactive with other compounds dissolved in water. Therefore, DO is consumed through reaction with organic material and minerals over time. Younger groundwater typically contains more $\mathrm{DO}$ and $\mathrm{CO}_{2}$ and has lower $\mathrm{pH}$ values than older groundwater. The concentrations of DO and $\mathrm{CO}_{2}$ in 53 to 55 samples for the NECB study were strongly and inversely correlated with apparent residence time (appendix 4), indicating that $\mathrm{DO}$ and $\mathrm{CO}_{2}$ concentrations decreased with increasing residence time of groundwater. The strong inverse correlations among apparent residence time with $\mathrm{DO}$ and $\mathrm{CO}_{2}$ show that these two gases are reliable indicators of young recharge waters and that, over time, DO and $\mathrm{CO}_{2}$ are probably consumed during water-rock weathering. For example, weathering of plagioclase feldspar by dissolved atmospheric $\mathrm{CO}_{2}$ produces hydrogen $(\mathrm{H})$ and bicarbonate $\left(\mathrm{HCO}_{3}\right)$ ions, which over time progressively increase $\mathrm{pH}$ and alkalinity (Hem, 1985).

Groundwater $\mathrm{pH}$ is a measure of the hydrogen ion activity in water and is an important control on the solubility of many trace elements. Highly acidic (low $\mathrm{pH}$ ) or highly alkaline (high $\mathrm{pH}$ ) waters can be corrosive to pipes and may have an unpleasant taste. The USEPA recommends a $\mathrm{pH}$ range of 6.5 to 8.5 for drinking water (U.S. Environmental Protection Agency, 2009). The spatial distribution of $\mathrm{pH}$ values in water samples collected from the studied wells is shown in figure 6 . Measurements of $\mathrm{pH}$ in water samples from 2,019 domestic and public-supply wells were mostly in the range of 6.5 to 8.2 ; the median value was 7.6 (table 8; fig. 7A). However, 9 percent of the $\mathrm{pH}$ values for all wells studied were below 6.5 and nearly 4 percent were greater than 8.5 (table 9). In addition, $\mathrm{pH}$ values were significantly higher in the public-supply and domestic wells in New England than in the NJ-NY domestic wells (fig. 7A). The significantly lower $\mathrm{pH}$ values and higher DO concentrations in the water samples from the NJ-NY domestic wells (figs. 7A-B) indicate apparent residence times that probably are younger than those for water samples from the domestic wells in New England.

Alkalinity, a measurement of the ability of water to neutralize acids, is an important consideration in the operation of water-treatment systems. Field and (or) laboratory alkalinity concentrations in 116 domestic well samples were mostly in the range of 27 to $178 \mathrm{mg} / \mathrm{L}$ as calcium carbonate $\left(\mathrm{CaCO}_{3}\right)$; the median value was $72 \mathrm{mg} / \mathrm{L}$ as $\mathrm{CaCO}_{3}$ (table 8). Older bedrock groundwater typically contains more alkalinity and have higher $\mathrm{pH}$ values than younger groundwater. The $\mathrm{pH}$ values and alkalinity concentrations in 55 samples for the NECB study were strongly and positive correlated with apparent residence time (appendix 4), indicating that groundwaters with high $\mathrm{pH}$ and high alkalinity concentrations are generally associated with older, chemically evolved groundwater.

Specific conductance, a measure of the ability of water to conduct an electric current, is an indicator of the amount of dissolved ions in water. Dissolved ions make up a large fraction of the total dissolved solids in natural waters; specific conductance and total dissolved solids (TDS) were closely related in the domestic wells studied (linear $R^{2}$ equal to 0.97 , $\mathrm{n}=117)$. Measurements of specific conductance in water samples from 821 domestic and public-supply wells were mostly in the range of 120 to 609 microsiemens per centimeter $(\mu \mathrm{S} / \mathrm{cm})$ at $25^{\circ}$ Celsius; the median measurement was $240 \mu \mathrm{S} / \mathrm{cm}$ (table 8). The relative amount of dissolved solids from natural sources in groundwater from NECR aquifers generally reflects the ability of minerals in native soils and aquifer materials to dissolve in water. Anthropogenic sources that can affect concentrations of dissolved solids include deicing salts on roads and leachate from onsite septic systems. Total dissolved solids has a U.S. Environmental Protection Agency secondary maximum contaminant level (SMCL) that relates primarily to aesthetic problems in drinking water, such as taste, hardness, mineral precipitation, and corrosiveness. Only 5 of the 117 domestic well samples (4.3 percent) had TDS concentrations equal to or greater than the USEPA SMCL of $500 \mathrm{mg} / \mathrm{L}$ (table 9). Three of the 5 samples with TDS concentrations exceeding the SMCL were from the NECB NAWQA study, and two were from the LINJ NAWQA study. Overall, specific conductance, TDS, and alkalinity concentrations in groundwater from NECR aquifers are among the lowest values when compared to those from other principal aquifers studied (DeSimone, 2009).

\section{Nutrients}

The widespread application of chemical fertilizers, manure, and sewage sludge to some agricultural fields to improve soil fertility and crop yields is a common practice in the Unites States (U.S. Geological Survey, 1999; Ruddy and others, 2006). One of the most significant changes in land use in New England and New Jersey since the 1960s has been the conversion of rural agricultural and forested lands to developed (residential and commercial) land uses (Ruddy and others, 2006; Guillard, 2008). As urban and suburban development replaces rural areas, developed lands and turf grass farming is replacing cropland as one of the largest fertilized areas in New England (Guillard, 2008). From 2002 to 2004 in Connecticut, Massachusetts, New Hampshire, 


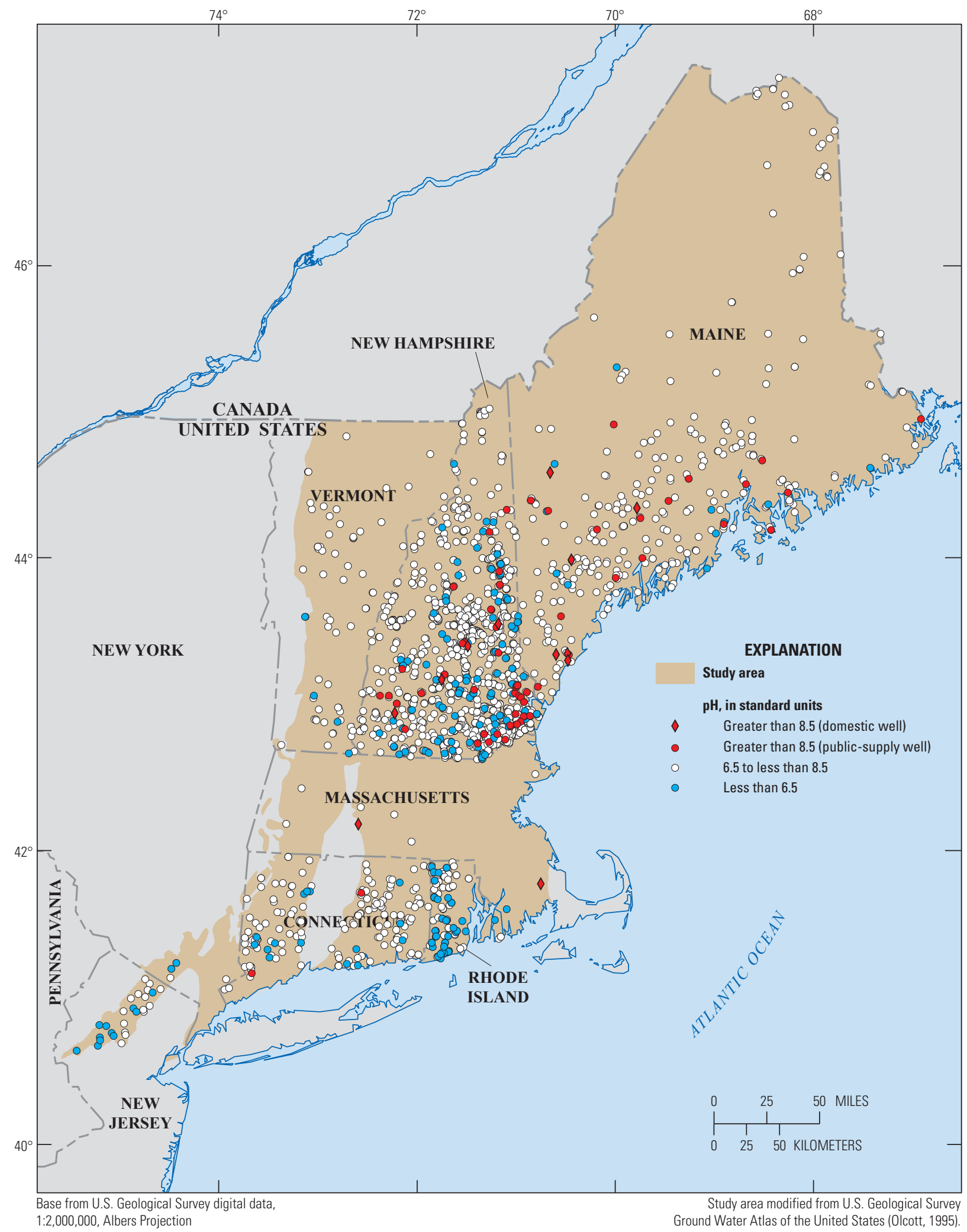

Figure 6. Spatial distribution of $\mathrm{pH}$ values in water samples collected from domestic and public-supply wells in New England crystalline rock aquifers, 1995-2007. 
A

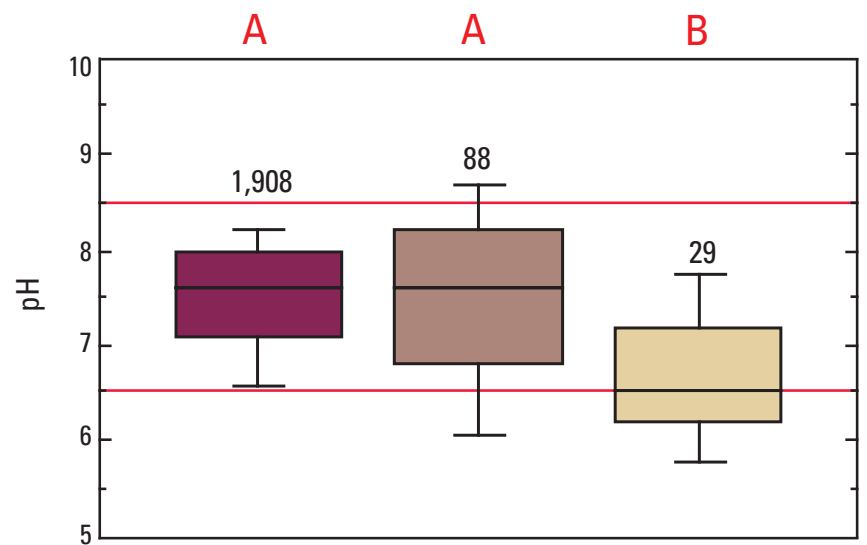

B

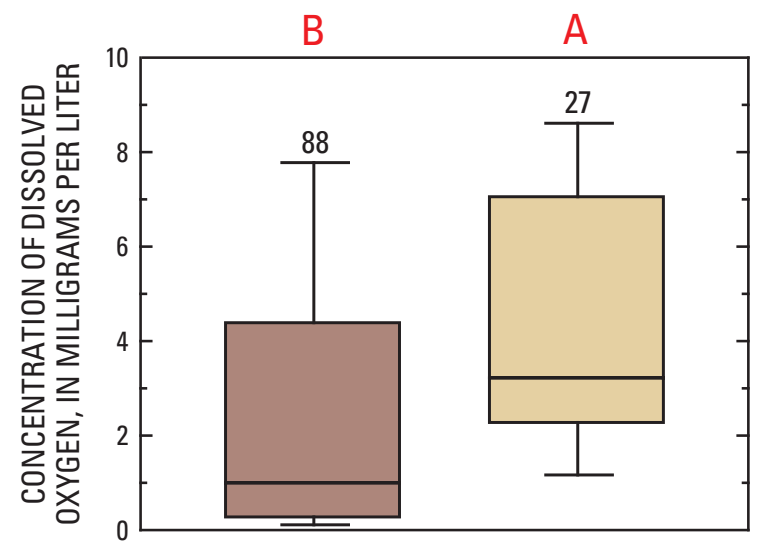

EXPLANATION
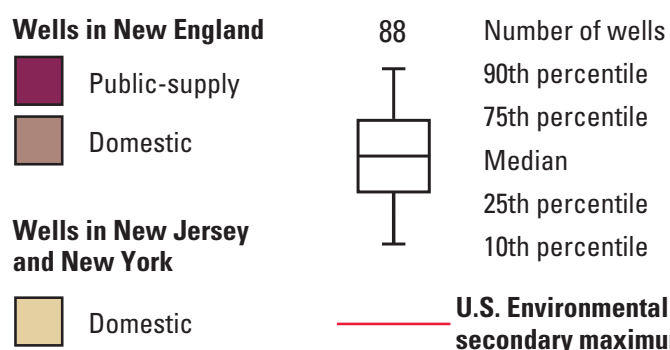

U.S. Environmental Protection Agency secondary maximum contaminant level

Statistical group from Tukey's test

A Groups with the same letter are not significantly different at an alpha value of 0.05

Figure 7. Distribution of $A, \mathrm{pH}$ values and $B$, concentrations of dissolved oxygen in water samples collected from public-supply and domestic wells in New England crystalline rock aquifers, 1995-2007.

Rhode Island, and New Jersey, the amount of nitrogen $(\mathrm{N})$-based fertilizers applied to farmland decreased while the amount of $\mathrm{N}$ fertilizers applied to nonfarmland increased, reflecting the trend of converting farmland to developed land (table 10). Atmospheric deposition of $\mathrm{N}$ is another major source of N to New England waters (U.S. Geological Survey, 1999; Boyer and others, 2002; Moore and others, 2004; Elliott and others, 2007). Owing in part to industrial and automotive emissions, rates of $\mathrm{N}$ deposition in New England are among the highest in the United States (National Atmospheric Deposition Program, 2000; Ruddy and others, 2006). Using data provided by Ollinger and others (1993), Moore and others (2004) showed that atmospheric deposition of total $\mathrm{N}$ in New England ranged from 320 to 1,030 kilograms per square kilometer per year $\left(\mathrm{kg} / \mathrm{km}^{2} / \mathrm{yr}\right)$. Recent trends in atmospheric deposition of total $\mathrm{N}$ indicate that the amount of $\mathrm{N}$ inputs from atmospheric deposition decreased from 2002 to 2004 in all six
New England States, but increased in New Jersey (table 10). Other sources of $\mathrm{N}$ and $\mathrm{P}$ compounds in groundwater include septic-disposal systems (especially in rural areas where septic systems are common), domestic animal wastes (manure), and infiltration of runoff from streets and parking lots. Locally, bedrock blasting activities may cause short-term $\mathrm{N}$ contamination in nearby wells by the partial combustion of explosives comprising of ammonium nitrate fuel oil (ANFO) (Kernan, 2010).

In 88 domestic wells in New England, total P concentrations ranged from $<0.01$ to $0.22 \mathrm{mg} / \mathrm{L}$ and orthophosphate $\left(\mathrm{PO}_{4}\right)$ concentrations ranged from $<0.01$ to $0.22 \mathrm{mg} / \mathrm{L}$ (appendix 1). In the $29 \mathrm{NJ}-\mathrm{NY}$ domestic wells, the maximum total $\mathrm{P}$ and $\mathrm{PO}_{4}$ concentrations both were $0.06 \mathrm{mg} / \mathrm{L}$ as $\mathrm{P}$ (appendix 2). Orthophosphate is the most common form of $\mathrm{P}$ in groundwater but is mostly immobile in groundwater because it tends to adsorb onto soils and aquifer materials. 


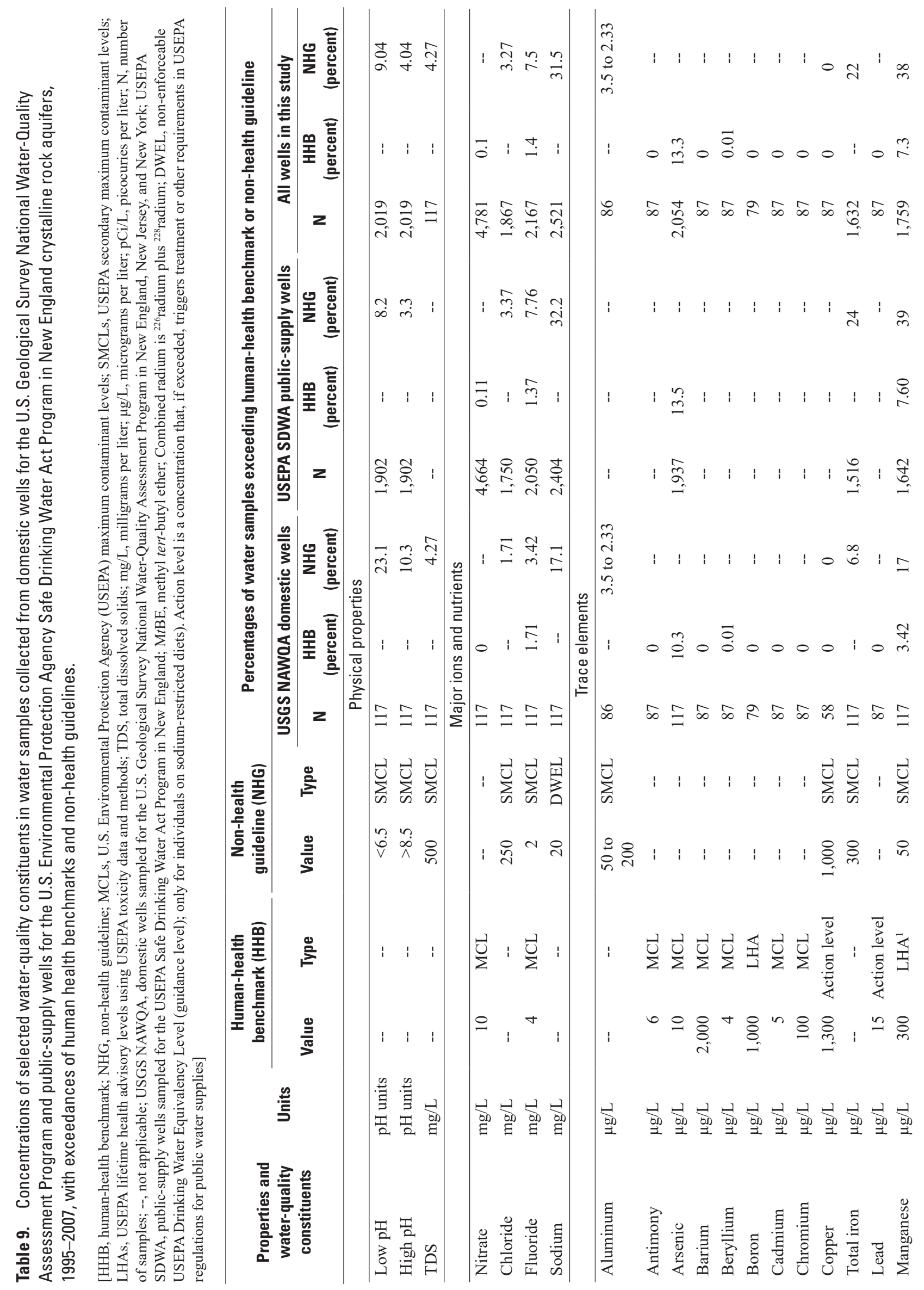




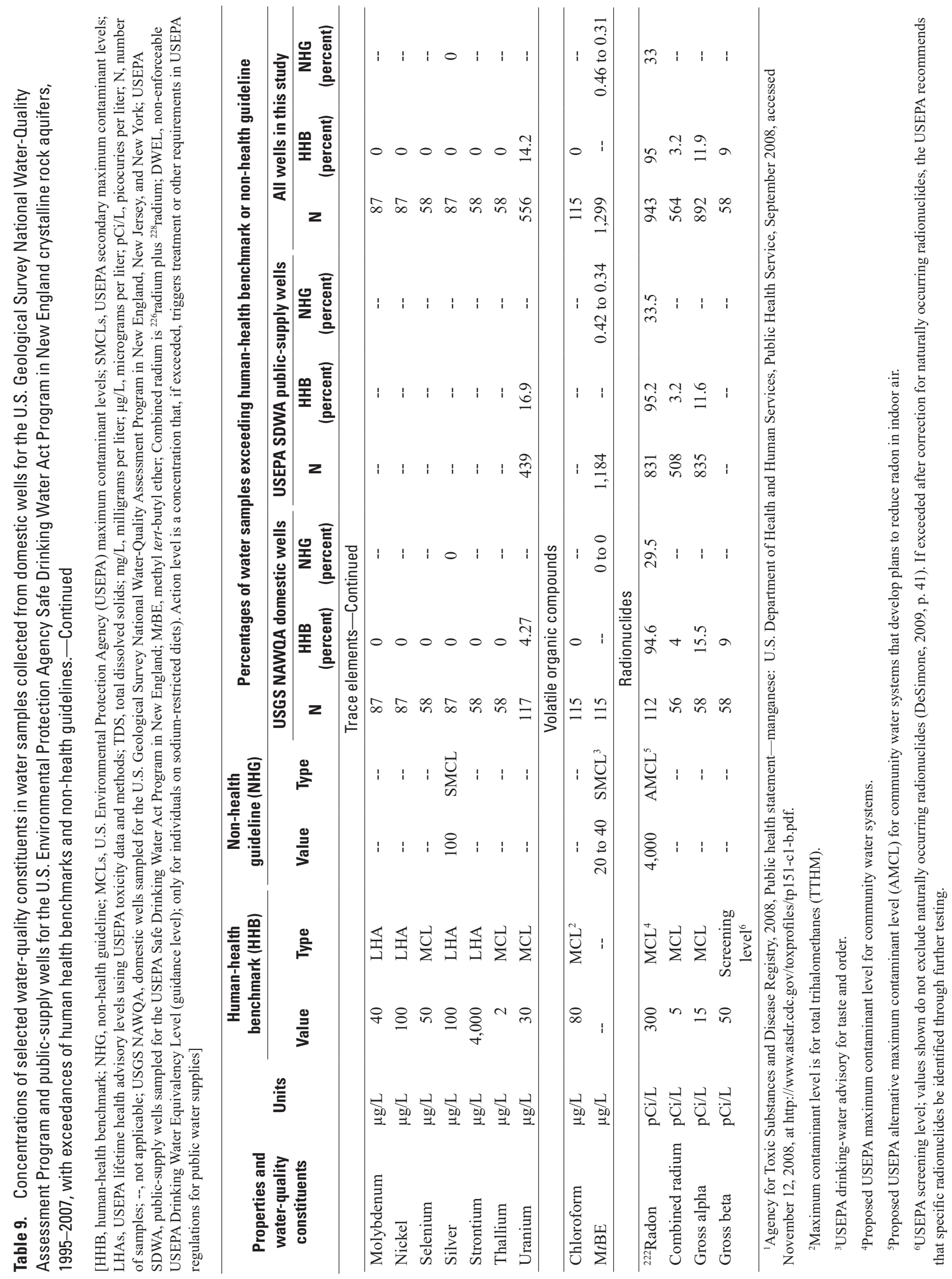


Table 10. Sources and quantities of nitrogen inputs in New England States and in New Jersey, 2002 and 2004.

[ $\mathrm{km}^{2}$, square kilometers; kg/km², kilograms per square kilometer; UNC, unconfined lots; CON, confined lots. Data from Ruddy and others, 2006]

\begin{tabular}{|c|c|c|c|c|c|c|c|c|c|}
\hline \multirow{3}{*}{ State } & \multirow{3}{*}{$\begin{array}{l}\text { Area } \\
\left(\mathrm{km}^{2}\right)\end{array}$} & \multicolumn{4}{|c|}{ Fertilizer } & \multirow{2}{*}{\multicolumn{2}{|c|}{$\begin{array}{c}\text { Manure } \\
2002\end{array}$}} & \multicolumn{2}{|c|}{ Atmospheric deposition } \\
\hline & & \multicolumn{2}{|c|}{2002} & \multicolumn{2}{|c|}{2004} & & & \multirow{2}{*}{$\begin{array}{c}2002 \\
\mathrm{~kg} / \mathrm{km}^{2}\end{array}$} & \multirow{2}{*}{$\begin{array}{c}2004 \\
\mathrm{~kg} / \mathrm{km}^{2}\end{array}$} \\
\hline & & $\begin{array}{c}\text { Farm } \\
\left(\mathrm{kg} / \mathrm{km}^{2}\right)\end{array}$ & $\begin{array}{l}\text { Nonfarm } \\
\left(\mathbf{k g} / \mathbf{k m}^{2}\right)\end{array}$ & $\begin{array}{c}\text { Farm } \\
\left(\mathrm{kg} / \mathrm{km}^{2}\right)\end{array}$ & $\begin{array}{l}\text { Nonfarm } \\
\left(\mathrm{kg} / \mathrm{km}^{2}\right)\end{array}$ & $\begin{array}{c}\text { UNC } \\
\left(\mathrm{kg} / \mathrm{km}^{2}\right)\end{array}$ & $\begin{array}{c}\text { CON } \\
\left(\mathrm{kg} / \mathrm{km}^{2}\right)\end{array}$ & & \\
\hline Connecticut & 12,853 & 692.1 & 269.3 & 460.6 & 359.4 & 61.7 & 210.4 & 493.4 & 444.0 \\
\hline Maine & 84,173 & 219.7 & 23.8 & 278.4 & 26.3 & 20.4 & 45.6 & 330.0 & 228.6 \\
\hline Massachusetts & 20,999 & 435.1 & 225.6 & 369.5 & 323.7 & 59.4 & 116.6 & 485.5 & 403.3 \\
\hline New Hampshire & 24,003 & 85.7 & 76.3 & 76.2 & 86.8 & 37.8 & 72.8 & 430.8 & 363.8 \\
\hline Rhode Island & 2,800 & 409.4 & 333.3 & 310.5 & 379.8 & 59.0 & 98.0 & 477.5 & 387.9 \\
\hline Vermont & 24,900 & 206.8 & 14.6 & 283.9 & 38.6 & 127.2 & 548.3 & 572.9 & 485.3 \\
\hline New Jersey & 19,517 & 978.0 & 429.0 & 708.0 & 493.0 & 72.0 & 115.0 & 470.0 & 671.0 \\
\hline
\end{tabular}

Nitrogen is the only nutrient for which there are enforceable USEPA drinking-water standards. The USEPA MCLs in community water systems is $1 \mathrm{mg} / \mathrm{L}$ as $\mathrm{N}$ for nitrite $\left(\mathrm{NO}_{2}\right), 10 \mathrm{mg} / \mathrm{L}$ as $\mathrm{N}$ for nitrate $\left(\mathrm{NO}_{3}\right)$, and $30 \mathrm{mg} / \mathrm{L}$ as $\mathrm{N}$ for ammonia $\left(\mathrm{NH}_{3}\right)$ (U.S. Environmental Protection Agency, 2009). None of the water samples from the 117 NAWQA domestic wells had $\mathrm{NO}_{2}$ concentrations that exceeded the MCL, and only five samples contained measureable $\mathrm{NO}_{2}$ concentrations above the laboratory reporting level (LRL) of $0.01 \mathrm{mg} / \mathrm{L}$ as $\mathrm{N}$. The maximum $\mathrm{NO}_{2}$ concentration was $0.08 \mathrm{mg} / \mathrm{L}$ as $\mathrm{N}$ (appendixes $1-2$ ).

While $\mathrm{NH}_{3}$ is soluble in water, $\mathrm{NH}_{3}$ is more likely to adsorb onto soils and aquifer materials. Ammonia was detected $(>0.02 \mathrm{mg} / \mathrm{L}$ as $\mathrm{N})$ in about 11 percent of the 88 domestic wells in New England (appendix 1) and in about 21 percent of the 29 NJ-NY domestic wells (appendix 2). The largest $\mathrm{NH}_{3}$ concentration in any of the domestic wells studied was $0.22 \mathrm{mg} / \mathrm{L}$ as $\mathrm{N}$. The largest $\mathrm{NH}_{3}$ plus organic $\mathrm{N}$ concentration in any of the domestic wells studied was $0.3 \mathrm{mg} / \mathrm{L}$ as $\mathrm{N}$ (appendixes $1-2$ ). The relatively low concentrations of $\mathrm{NO}_{2}, \mathrm{NH}_{3}$, and $\mathrm{NH}_{3}$ plus organic $\mathrm{N}$ in the domestic well samples indicate that they are the least dominant forms of dissolved $\mathrm{N}$ in NECR aquifers.

Nitrate concentrations in this study were reported as $\mathrm{NO}_{2}$ plus $\mathrm{NO}_{3}$ as $\mathrm{N}$, but because $\mathrm{NO}_{2}$ accounts for less than 1 percent of the reported $\mathrm{NO}_{2}$ plus $\mathrm{NO}_{3}$ as $\mathrm{N}$ concentrations, the remainder of this report refers to those summed concentrations as $\mathrm{NO}_{3}$ concentrations. Nitrate is highly soluble and mobile; it can leach through permeable soils and migrate to underlying aquifers. Most of the $\mathrm{NO}_{3}$ that reaches groundwater has evolved chemically from organic $\mathrm{N}$ and $\mathrm{NH}_{3}$ applied on the land surface in the form of fertilizers and manure and as a byproduct of leachate from septic-disposal systems. In the northeastern United States, the volume of $\mathrm{N}$ compounds derived from atmospheric sources (precipitation and particulate matter) is significant, especially to the region's largest rivers (Moore and others, 2004), but it is not known how much of the $\mathrm{NO}_{3}$ in NECR groundwater is ultimately derived from atmospheric sources.

Nitrate concentrations in 4,781 untreated water samples from the domestic and public-supply wells were mostly in the range of $<0.5$ to $1.6 \mathrm{mg} / \mathrm{L}$, with a maximum concentration of $18.4 \mathrm{mg} / \mathrm{L}$ (table 8). Only 5 water samples from 4,664 public-supply wells $\left(<1\right.$ percent) had $\mathrm{NO}_{3}$ concentrations that exceeded the MCL (table 9). None of the water samples from the 117 domestic wells had $\mathrm{NO}_{3}$ concentrations that exceeded the MCL (table 9). By comparison, DeSimone (2009) reported that 4.4 percent of 2,132 domestic wells from all aquifers sampled nationally for the NAWQA Program had a $\mathrm{NO}_{3}$ concentration greater than the MCL. However, the median $\mathrm{NO}_{3}$ concentration $(1.04 \mathrm{mg} / \mathrm{L}$; appendix 2$)$ in the $29 \mathrm{NJ}-\mathrm{NY}$ domestic well samples was at least 20 times higher than the median concentration $(<0.05 \mathrm{mg} / \mathrm{L}$; appendix 1$)$ in the 88 domestic well samples from New England and nearly twice the median concentration $(0.55 \mathrm{mg} / \mathrm{L})$ that DeSimone (2009) reported for the domestic wells sampled from all aquifers nationally for the NAWQA Program.

In the NECR aquifers, the higher $\mathrm{NO}_{3}$ concentrations in the sampled wells appear to coincide with areas of higher population density, as illustrated by the spatial distribution of $\mathrm{NO}_{3}$ concentrations in water samples from the domestic and public-supply wells in figure 8 . The percentage of samples ( 21.3 percent) with $\mathrm{NO}_{3}$ concentrations $>1 \mathrm{mg} / \mathrm{L}$ from publicsupply wells where population density was high ( $>50$ persons/ $\mathrm{km}^{2}$ ) was significantly (and statistically) greater than the percentage of samples (12.3 percent) in public-supply wells where population density was low ( $\leq 50$ persons $\left./ \mathrm{km}^{2}\right)$ (fig. 9). The percentage of samples (33.9 percent) with $\mathrm{NO}_{3}$ concentrations $>1 \mathrm{mg} / \mathrm{L}$ from domestic wells where population density was high also was significantly greater than the percentage of samples (10.9 percent) from domestic wells where population density was low (fig. 9). Interestingly, although 


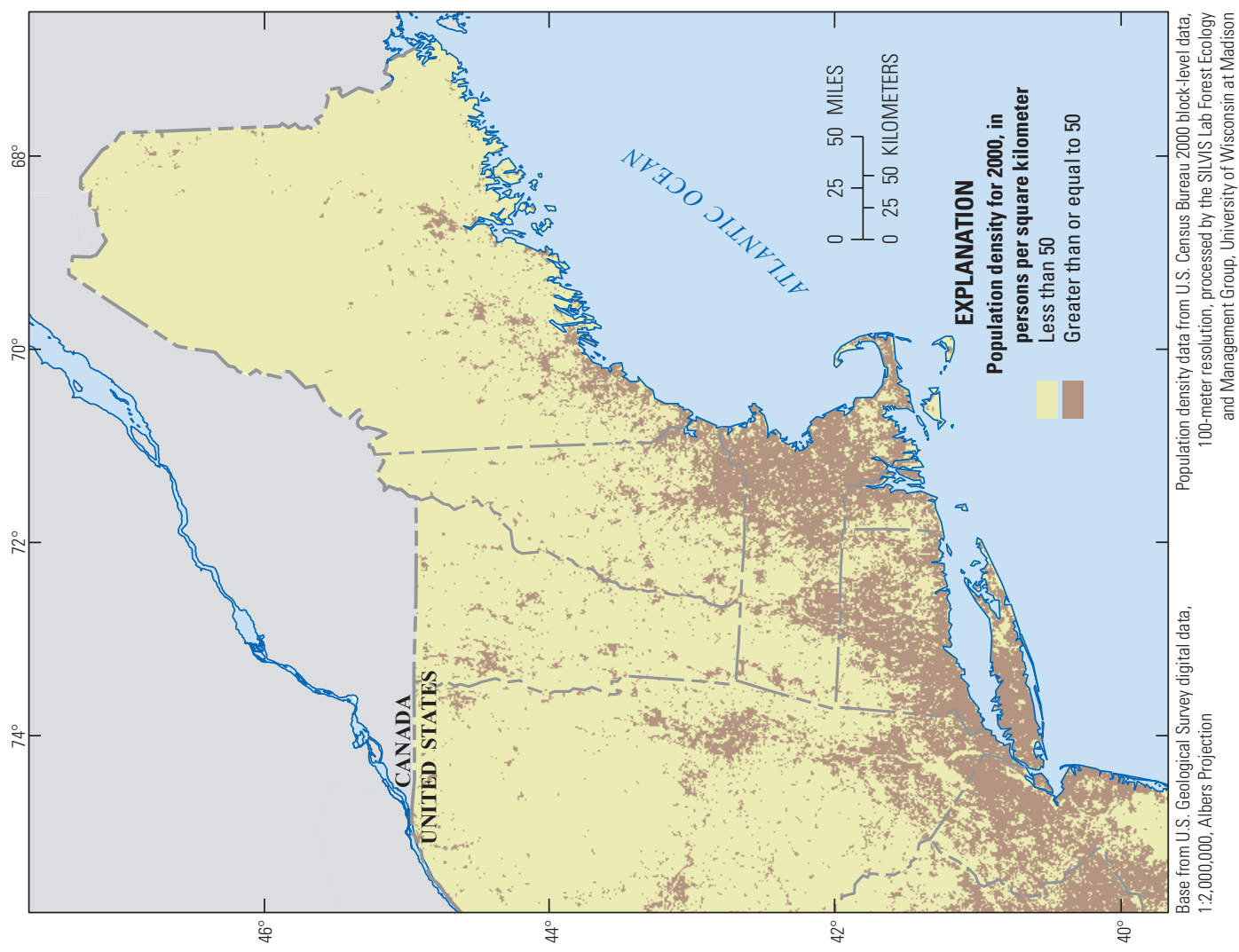

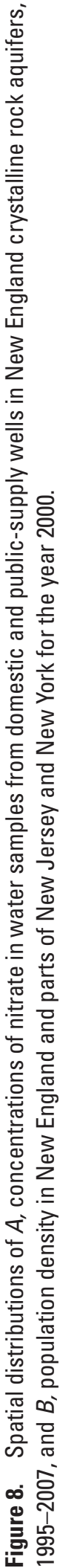

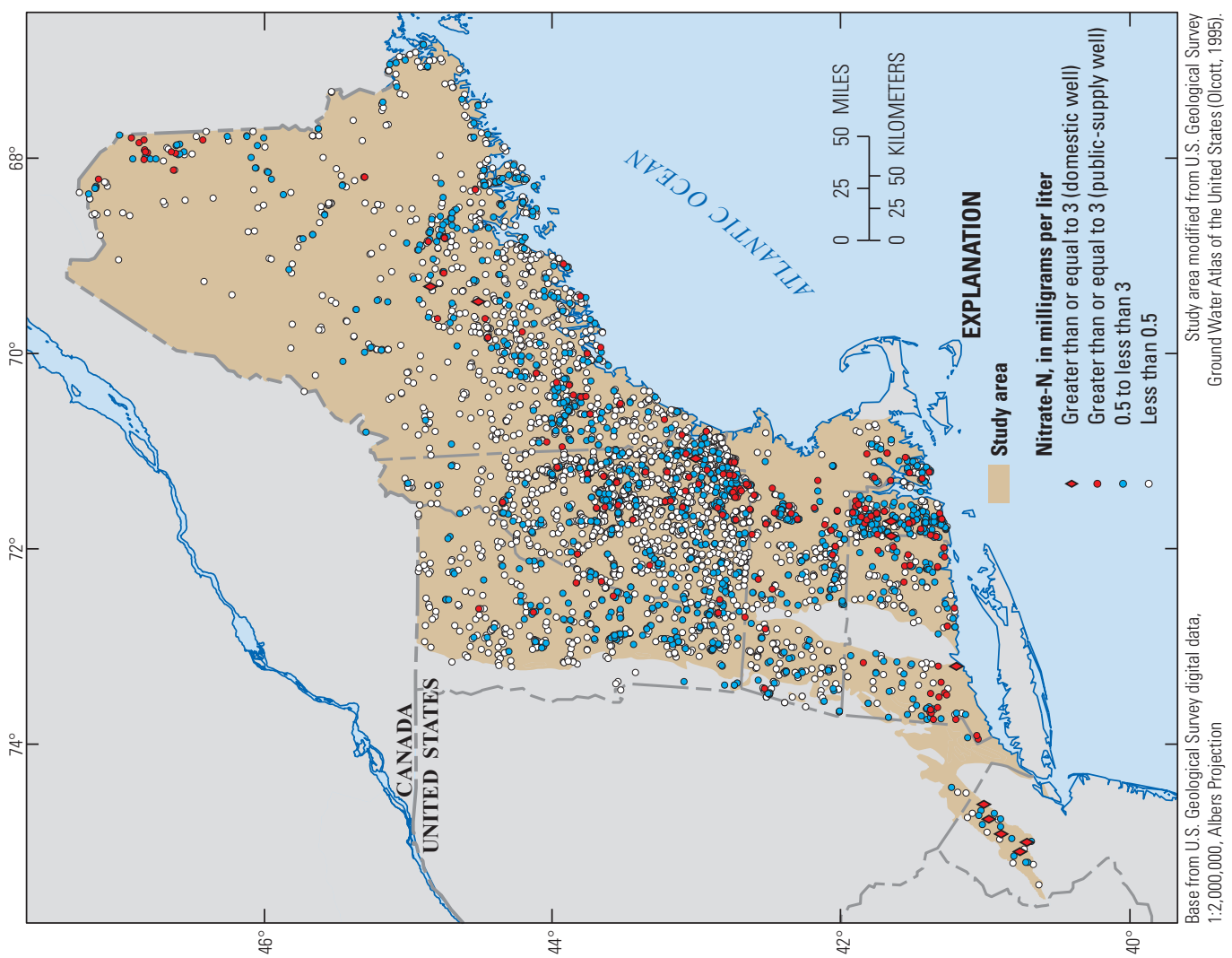



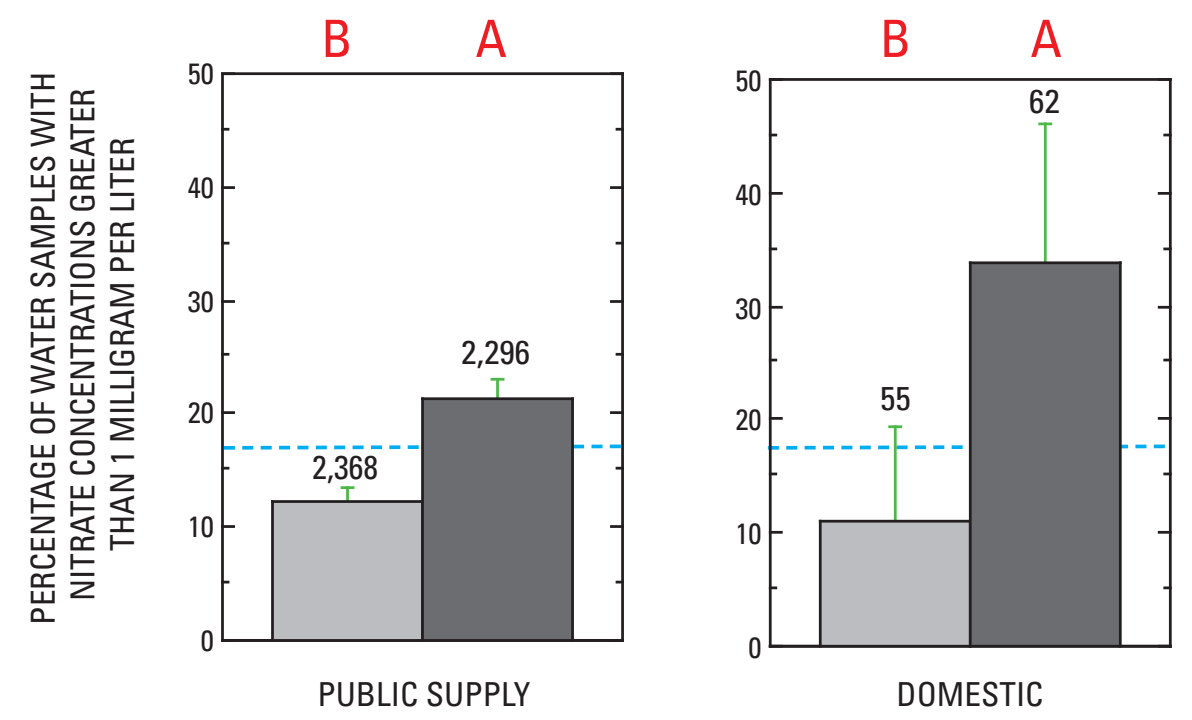

EXPLANATION

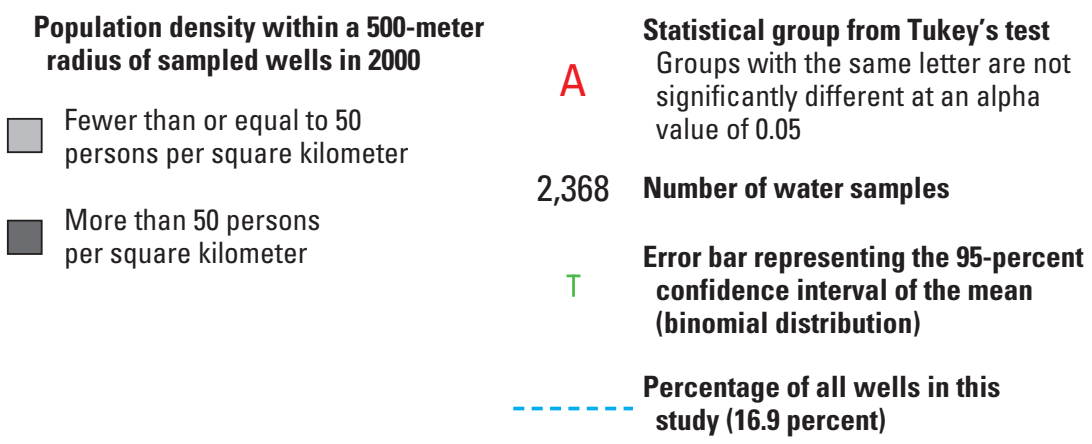

Figure 9. Distribution of percentages of water samples with concentrations of nitrate greater than 1 milligram per liter collected from public-supply and domestic wells in New England crystalline rock aquifers, by categories of population density, 1995-2007.
$\mathrm{NO}_{3}$ concentrations $>1 \mathrm{mg} / \mathrm{L}$ occurred more frequently in domestic well samples in areas where the dominant land use is developed lands, $\mathrm{NO}_{3}$ concentrations $>1 \mathrm{mg} / \mathrm{L}$ occurred more frequently in public-supply well samples in areas where the dominant land use is agricultural (fig. 10). However the $\mathrm{NO}_{3}$ occurrence rates were not significantly different for the public-supply well samples among the four land-use categories. Only the domestic well samples in the undeveloped land-use category had a significantly lower occurrence rate of $\mathrm{NO}_{3}$ concentrations $>1 \mathrm{mg} / \mathrm{L}$ than those from areas where the dominant land use was agricultural, developed, or mixed (fig. 10). The percentage of samples (20 percent) with $\mathrm{NO}_{3}$ concentrations $>1 \mathrm{mg} / \mathrm{L}$ from shallow wells (total well depths $\leq 300 \mathrm{ft}$ and casing lengths $\leq 50 \mathrm{ft}$ ) was significantly (and statistically) greater than the percentage of samples ( 6 percent) from deep wells (total well depths $>300 \mathrm{ft}$ and casing lengths $>50 \mathrm{ft}$ ) (fig. 11), indicating that higher $\mathrm{NO}_{3}$ concentrations are associated with shallower groundwater.

The percentages of water samples from public-supply and domestic wells with concentrations of $\mathrm{NO}_{3}$ greater than $0.5 \mathrm{mg} / \mathrm{L}$ (the common LRL), greater than $3 \mathrm{mg} / \mathrm{L}$, and greater than $6 \mathrm{mg} / \mathrm{L}$ are shown in figure 12. The bar charts in figure 12 show that with increasing concentrations of $\mathrm{NO}_{3}$, there is a greater percentage of water samples from the domestic wells that equaled or exceeded the stated concentrations of $\mathrm{NO}_{3}$ than the water samples from the public-supply wells. For example, 5 times as many water samples from the domestic wells (2.5 percent) had $\mathrm{NO}_{3}$ concentrations greater than $6 \mathrm{mg} / \mathrm{L}$ than did water samples from the public-supply wells ( 0.5 percent; fig. 12C). Three times as many had $\mathrm{NO}_{3}$ concentrations greater than $3 \mathrm{mg} / \mathrm{L}$, and 1.3 times as many had $\mathrm{NO}_{3}$ concentrations greater than $0.5 \mathrm{mg} / \mathrm{L}$ (figs. 12A-B). One possible explanation for the higher $\mathrm{NO}_{3}$ concentrations in domestic well samples is that homeowners may have less flexibility in siting wells within their property boundaries than do public utilities. Domestic wells may be close to neighboring homes that have septic systems, and they may be sited on managed lawns where fertilizers are applied. Elevated $\mathrm{NO}_{3}$ concentrations in groundwater underlying some residential areas may also be due to previous land-use practices. About half of the water samples in New Jersey and New York were from domestic wells drilled on land previously used for agriculture (Leon J. Kauffman, U.S. Geological Survey, oral commun., 2009). The domestic well sample in New England with the highest $\mathrm{NO}_{3}$ concentration $(8.96 \mathrm{mg} / \mathrm{L})$ was from a home on a working farm that has been in use for decades (Robinson and others, 


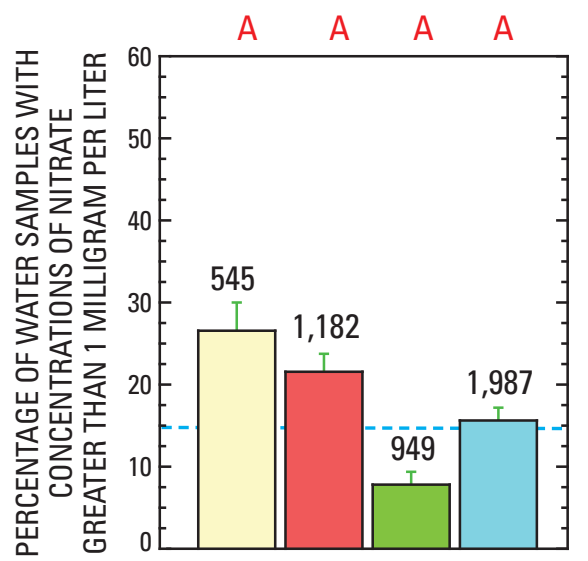

PUBLIC-SUPPLY

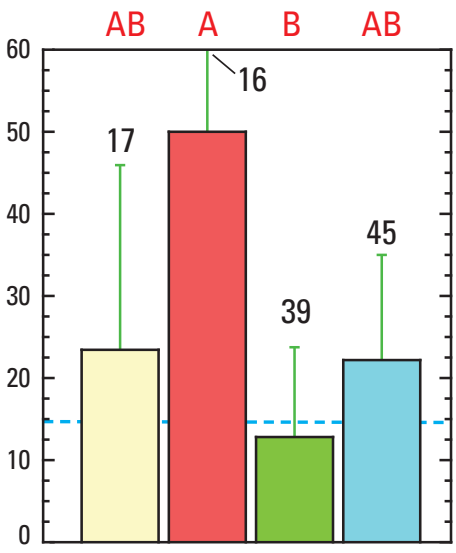

DOMESTIC

\section{EXPLANATION}

Dominant land use in a $\mathbf{5 0 0}$-meter radius of sampled wells

\section{Agriculture}

Agricultural land uses are greater than 15 percent and developed land uses are less than or equal to 5 percent

Developed

Developed (urban) land uses are greater than 25 percent and agricultural land uses are less than or equal to 15 percent

\section{Undeveloped}

Undeveloped land uses are equal to or greater than 85 percent

\section{Mixed}

No dominant land use

Statistical group from Tukey's test

A Groups with the same letter are not significantly different at an alpha value of 0.05

\section{Number of water samples}

Error bar representing the 95-percent confidence interval of the mean (binomial distribution)

- - - - Percentage of all wells in the study $(16.9 \%)$

Figure 10. Distribution of percentages of water samples with concentrations of nitrate greater than 1 milligram per liter collected from public-supply and domestic wells in New England crystalline rock aquifers, by major category of land use within a 500-meter radius of the sampled wells, 1995-2007.

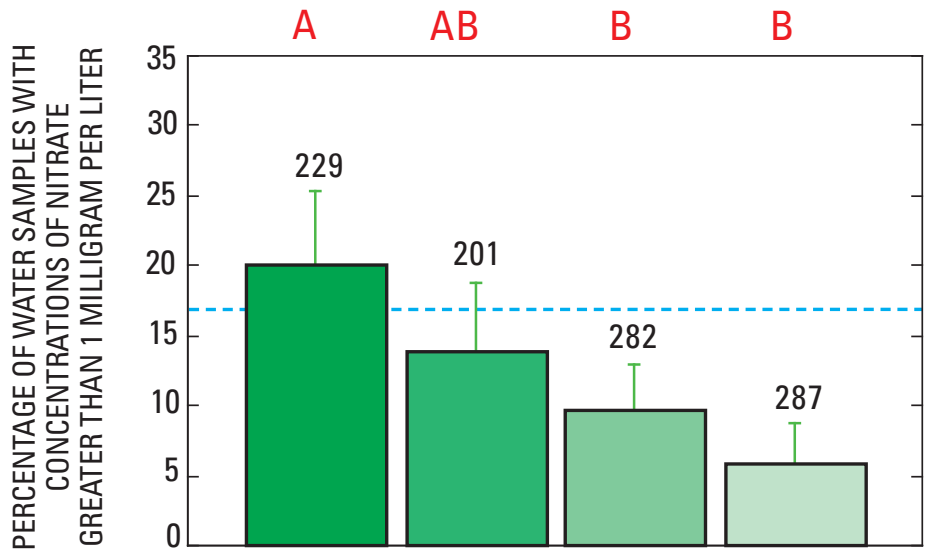

\section{EXPLANATION}

Shallow well, short casing length

Total depth of well is less than or equal to 300 feet and depth to the bottom of well casing is less than or equal to 50 feet

Shallow well, long casing length

Total depth of well is less than 300 feet and depth to the bottom of well casing is greater than 50 feet

Deep well, short casing length

Total depth of well is greater than 300 feet and depth to the bottom of well casing is less than or equal to 50 feet

Deep well, long casing length

Total depth of well is greater than 300 feet and depth to the bottom of well casing is greater than 50 feet

Statistical group from Tukey's test

A Groups with the same letter are not significantly different at an alpha value of 0.05

\section{Number of water samples}

\section{Error bar representing the 95-percent confidence} interval of the mean (binomial distribution)

\section{- - - - - Percentage of all wells in the study $(16.9 \%)$}

Figure 11. Distribution of percentages of water samples with concentrations of nitrate greater than 1 milligram per liter collected from public-supply and domestic wells in New England crystalline rock aquifers, by categories of well depth and casing length, 1995-2007. See table 5 for the distribution of sampled wells on the basis of categories of well depth and casing length. 

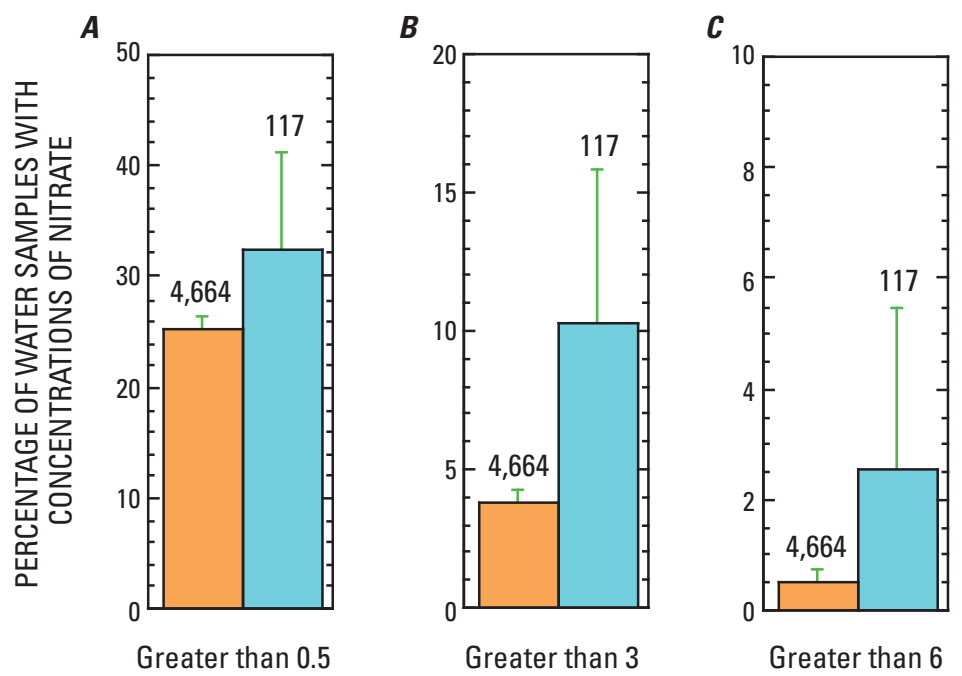

\section{EXPLANATION}

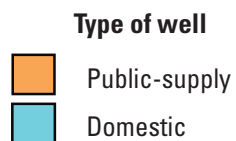

117 Number of samples

Error bar representing the 95-percent confidence interval of the mean (binomial distribution)

IN MILLIGRAMS PER LITER

Figure 12. Distribution of percentages of water samples with concentrations of nitrate greater than $A, 0.5, B, 3$, and $C, 6$ milligrams per liter collected from public-supply and domestic wells in New England crystalline rock aquifers, 1995-2007.

2004). The public-supply wells also are generally greater in total depth and have longer well casings than the domestic wells (table 6). These conditions may explain why $\mathrm{NO}_{3}$ concentrations are generally lower in groundwater from public-supply wells than from domestic wells.

Nitrate concentrations in the water samples were strongly correlated with other variables, such as apparent residence time (appendix 4), specific conductance concentrations, DO concentrations, $\mathrm{pH}$, and $\mathrm{CO}_{2}$ gas concentrations (appendix 5). These correlations indicate that the largest $\mathrm{NO}_{3}$ concentrations in NECR aquifers are associated with young, oxic, shallow groundwater that is in close proximity to the source of $\mathrm{NO}_{3}$ (such as local use of fertilizers or nearby septic systems). Under these conditions, $\mathrm{NO}_{3}$-enriched groundwater would have little time to undergo denitrification processes.

\section{Major Ions}

Under natural conditions, major dissolved ions in NECR aquifers are controlled by aquifer mineralogy and the residence time of groundwater in the system. Natural waters are commonly categorized by water type based on the relative percentage of major ions in the sample. The presence of any particular major ion in groundwater generally may not pose a specific serious risk to human health, but understanding the type of water produced from an aquifer can be valuable in understanding some of the processes that affect the waterquality conditions in groundwater.

Water types of samples collected from the domestic wells for the NAWQA Program are illustrated in the trilinear diagram in figure 13, which highlights the variability in the major ion chemistry of groundwater from NECR aquifers. Calcium $(\mathrm{Ca})$ was the most abundant cation, and bicarbonate $\left(\mathrm{HCO}_{3}\right)$ was the most abundant anion, in most of the domestic well samples. Water samples from domestic wells in New England were primarily calcium-bicarbonate $\left(\mathrm{Ca}-\mathrm{HCO}_{3}\right)$ water type with some calcium-chloride $(\mathrm{Ca}-\mathrm{Cl})$, sodium-chloride (Na-Cl), sodium-bicarbonate $\left(\mathrm{Na}-\mathrm{HCO}_{3}\right)$, and sodium-sulfate $\left(\mathrm{Na}-\mathrm{SO}_{4}\right.$ ) types (fig. 14). Water samples from the NJ-NY domestic wells were $\mathrm{Ca}-\mathrm{Cl}$ or $\mathrm{Ca}-\mathrm{HCO}_{3}$ water types (fig. 14).

Initially, the interaction of precipitation and aquifer materials dissolves readily weathered minerals, such as calcite, which releases $\mathrm{Ca}$, consumes hydrogen $(\mathrm{H})$, and increases alkalinity. The $\mathrm{Ca}-\mathrm{HCO}_{3}$ type water samples generally indicate young, recently recharged groundwater in NECR aquifers (Rogers, 1989; Lipfert and others, 2006). As groundwater evolves with time, less reactive minerals such as feldspars and micas can dissolve. The $\mathrm{Na}-\mathrm{HCO}_{3}$ type water samples can indicate longer residence times where silicate hydrolysis allows for the dissolution of Na-feldspar, or cation exchange, or a combination of both (Rogers, 1989; Toran and Saunders, 1999; Bowser and Jones, 2002; Lipfert and others, 2006).

Calcium and magnesium $(\mathrm{Mg})$ are the primary cations contributing to hardness, a property of water that has been used to describe the extent to which soap lathers readily in water and the tendency for deposition of scale on solid surfaces when the water is heated (Hem, 1985). In 117 domestic well samples, $\mathrm{Ca}$ concentrations ranged from 2.7 to $98.5 \mathrm{mg} / \mathrm{L}$ and $\mathrm{Mg}$ concentrations ranged from 0.4 to $31 \mathrm{mg} / \mathrm{L}$ (table 8). Waters with a hardness of less than $60 \mathrm{mg} / \mathrm{L}$ as 


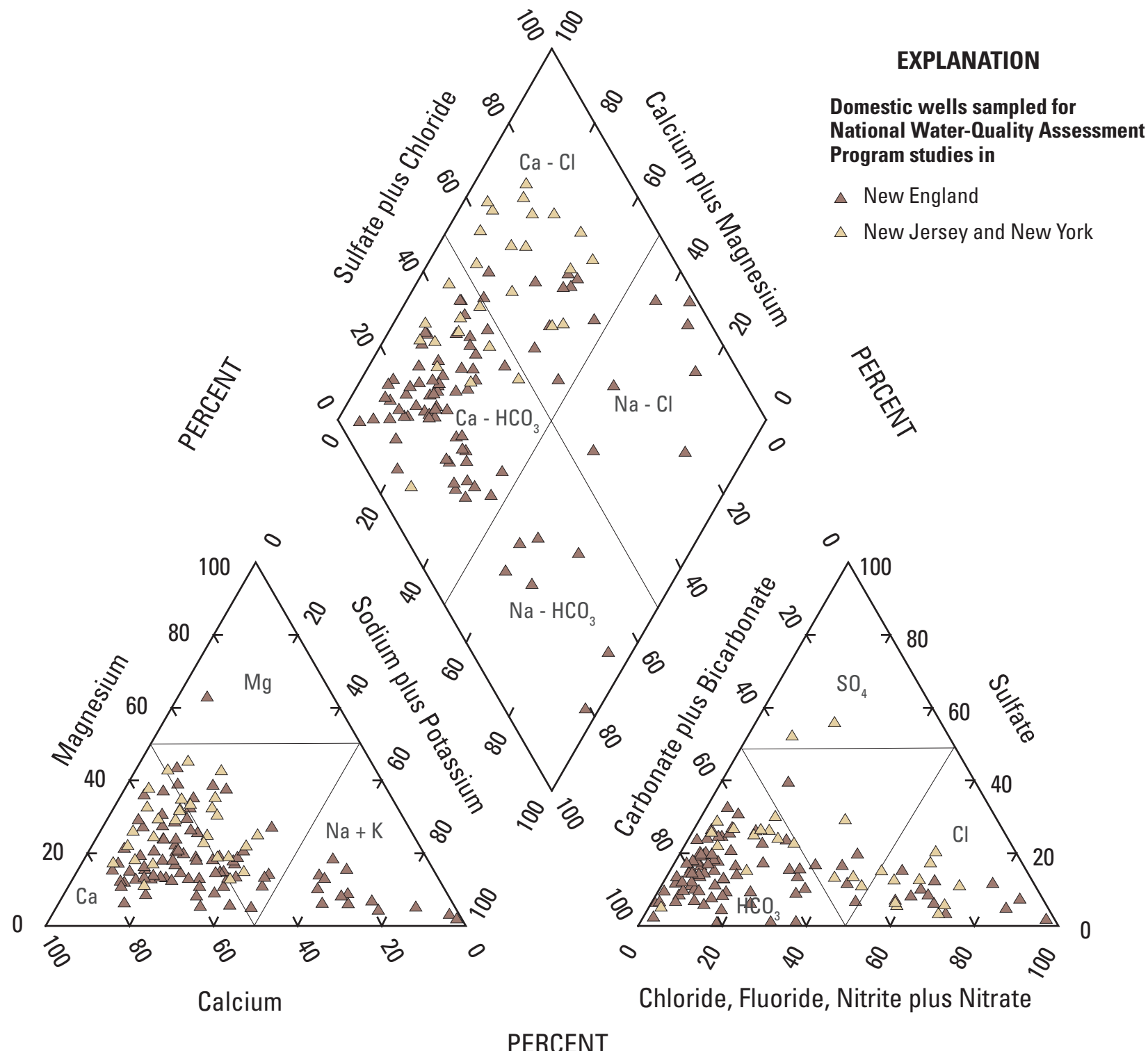

Figure 13. Trilinear diagram showing relations among major ions in water samples collected from domestic wells in New England crystalline rock aquifers, 1995-2000. (Ca, calcium; Mg, magnesium; $\mathrm{Na}+\mathrm{K}$, sodium plus potassium; $\mathrm{HCO}_{3^{\prime}}$ bicarbonate; $\mathrm{Cl}$, chloride; $\mathrm{SO}_{4}$, sulfate) 


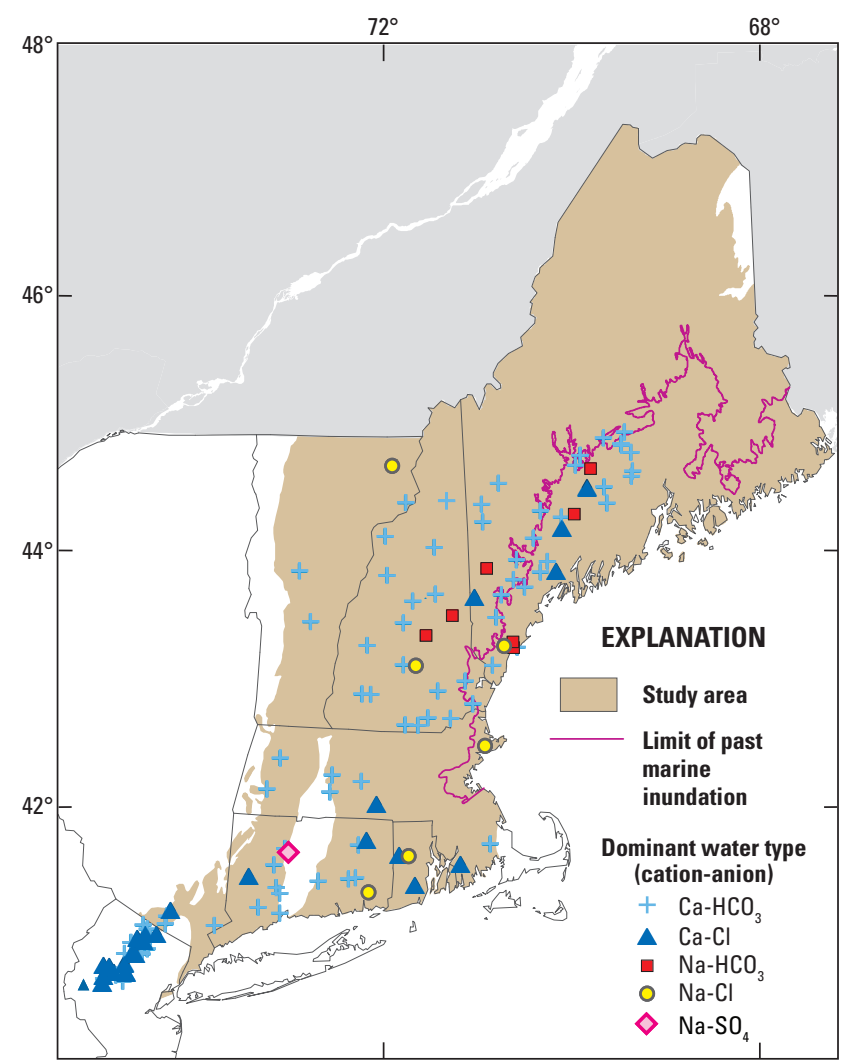

Figure 14. Dominant water types in water samples collected from domestic wells in New England crystalline rock aquifers, 1995-2000. (Ca- $\mathrm{HCO}_{3}$, calcium-bicarbonate; Ca-Cl, calciumchloride; $\mathrm{Na}-\mathrm{HCO}_{3}$, sodium-bicarbonate; $\mathrm{Na}-\mathrm{Cl}$, sodium-chloride; $\mathrm{Na}-\mathrm{SO}_{4}$, sodium-sulfate)

$\mathrm{CaCO}_{3}$ are considered "soft," and waters with more than $120 \mathrm{mg} / \mathrm{L}$ as $\mathrm{CaCO}_{3}$ are considered "hard" (Hem, 1985). Hard or very hard (greater than $180 \mathrm{mg} / \mathrm{L}$ as $\mathrm{CaCO}_{3}$ ) waters, when used for drinking water, often require treatment by use of a water softener, a process in which dissolved $\mathrm{Ca}$ and $\mathrm{Mg}$ ions are exchanged with $\mathrm{Na}$ ions in the water. In 87 water samples from the domestic wells, hardness values ranged from 12.6 to $280 \mathrm{mg} / \mathrm{L}$ as $\mathrm{CaCO}_{3}$ (appendix 1). About 21 percent of these water samples were in the hard to very hard range. In general, NECR aquifers have lower hardness values when compared to other principal aquifers studied nationally (DeSimone, 2009).

The major anion sulfate $\left(\mathrm{SO}_{4}\right)$ has an SMCL that relates primarily to taste and odor. Sulfate concentrations in 117 domestic well samples ranged from 0.3 to $68.5 \mathrm{mg} / \mathrm{L}$, with a median concentration of $13.4 \mathrm{mg} / \mathrm{L}$ (table 8) - well below the USEPA SMCL of $250 \mathrm{mg} / \mathrm{L}$. Sulfate was the dominant anion in one of the domestic well samples for the CONN study (fig. 14).

\section{Sodium and Chloride}

Sodium and $\mathrm{Cl}$ concentrations varied greatly among water samples from the public-supply and domestic wells (table 8). In water samples from 2,521 public-supply and domestic wells, Na concentrations were mostly in the range of 4.4 to $51 \mathrm{mg} / \mathrm{L}$, with a median concentration of $12.3 \mathrm{mg} / \mathrm{L}$. In water samples from 1,867 public-supply and domestic wells, $\mathrm{Cl}$ concentrations were mostly in the range of 3 to $117 \mathrm{mg} / \mathrm{L}$, with a median concentration of $17 \mathrm{mg} / \mathrm{L}$ (table 8 ). The maximum $\mathrm{Na}(958 \mathrm{mg} / \mathrm{L})$ and $\mathrm{Cl}(1,800 \mathrm{mg} / \mathrm{L})$ concentrations were from the same water sample in a public-supply well in New Hampshire (appendix 3). The spatial distribution of $\mathrm{Cl}$ concentrations in water samples collected from the domestic and public-supply wells is shown in figure 15 . The USEPA does not have regulatory human health benchmarks for $\mathrm{Na}$ and $\mathrm{Cl}$, but the agency has established a non-enforceable Drinking Water Equivalency Level (DWEL, or guidance level) for persons on Na-restricted diets of $20 \mathrm{mg} / \mathrm{L}$ and a SMCL for $\mathrm{Cl}$ of $250 \mathrm{mg} / \mathrm{L}$ because of taste. Sodium concentrations exceeded the DWEL of $20 \mathrm{mg} / \mathrm{L}$ in 31.5 percent of all wells studied, and $\mathrm{Cl}$ concentrations equaled or exceeded the SMCL in about 3.3 percent of all wells studied (table 9). Concentrations of $\mathrm{Na}$ and $\mathrm{Cl}$ were significantly greater in water samples from the public-supply wells than from the domestic wells, but were not significantly different when the samples were evaluated on the basis of well-construction categories or geologic lithology groups.

Natural sources of $\mathrm{Na}$ and (or) $\mathrm{Cl}$ to NECR aquifers include remnant seawater that inundated coastal Maine and New Hampshire during the post-glacial (Quaternary) period (Tepper, 1980), modern-day seawater intrusion along coastal areas (Barlow, 2003), connate brines trapped during rock deposition, and atmospheric transport of seawater aerosols during ocean storms. Figure 14 shows the demarcation line that represents the maximum extent of marine inundation during the post-glacial period. Alkali plagioclase feldspars, such as albite and oligoclase, are common in granitic and metamorphic rocks. They contain $\mathrm{Na}$ and are more susceptible to chemical breakdown than potassium (K)-feldspars (Rogers, 1989; Hem, 1985). In addition, most metamorphic and igneous rocks in the Earth's crust have crystallized in the presence of fluids containing $\mathrm{Na}$ and $\mathrm{K}$, forming fluid inclusions and connate waters; these are another source of geogenic Na to NECR aquifers. Anthropogenic sources of $\mathrm{Na}$ and $\mathrm{Cl}$ include road salt and discharges from water softeners. The dominance of the $\mathrm{Cl}$ anion in some domestic well water types may indicate the influence of anthropogenic sources (fig. 14).

On a regional scale, concentrations of $\mathrm{Na}$ and $\mathrm{Cl}$ in water samples from the sampled wells were significantly different when grouped into categories of land use (fig. 16) and population density (fig. 17). Water samples from wells in areas dominated by developed land and in areas of high population density ( $\geq 50$ persons $/ \mathrm{km}^{2}$ ) had the highest concentrations of $\mathrm{Na}$ and $\mathrm{Cl}$, whereas the water samples from wells in areas dominated by undeveloped land and in areas of low population 


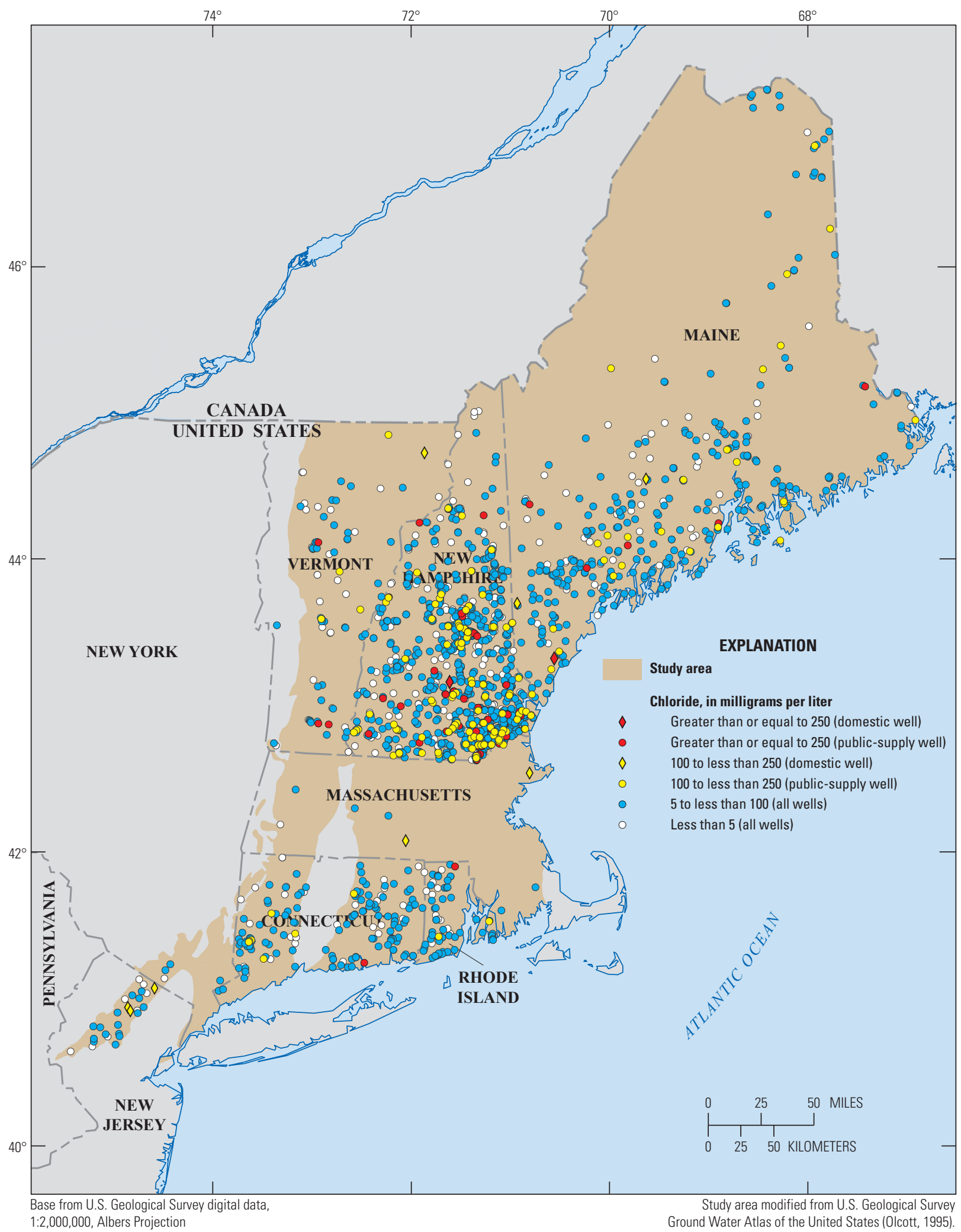

Figure 15. Spatial distribution of chloride concentrations in water samples collected from domestic and public-supply wells in New England crystalline rock aquifers, 1995-2007. 

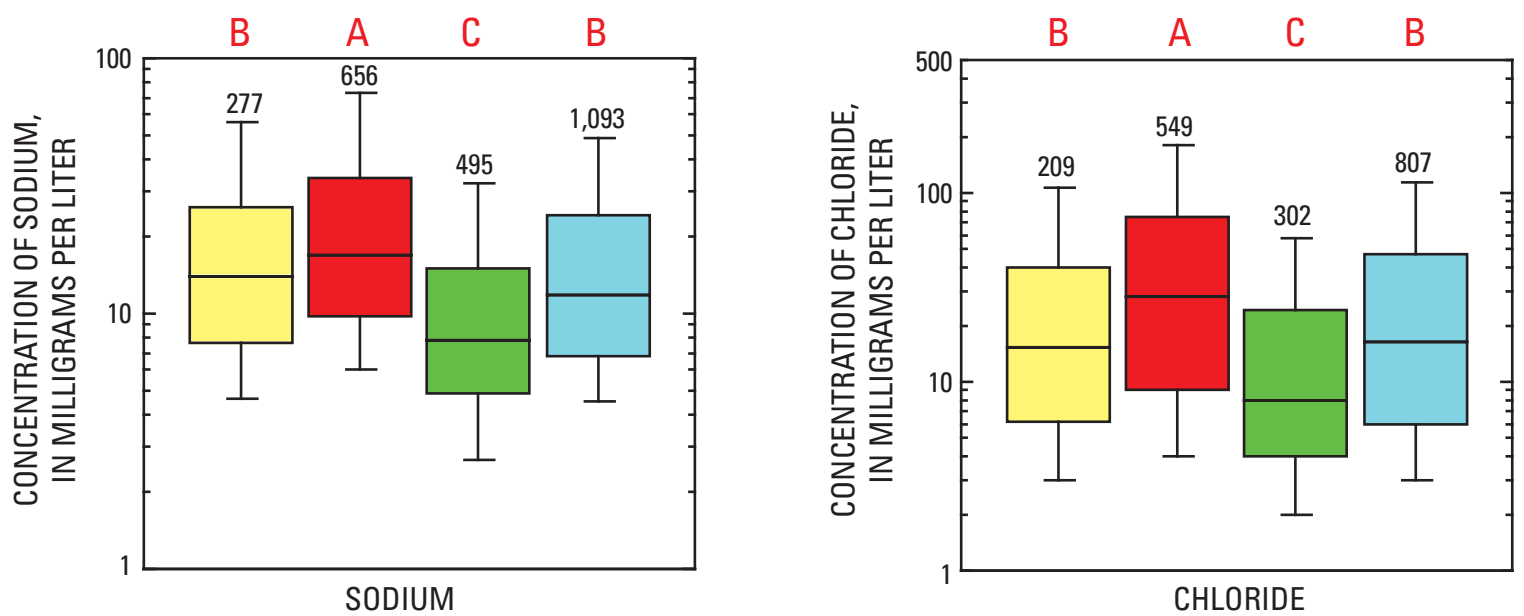

\section{EXPLANATION}

Dominant use of land within a 500-meter radius of sampled wells, in 2001

$\square$ Agriculture

Agricultural land uses are greater than 15 percent and developed

land uses are less than or equal to 5 percent

Developed

Developed (urban) land uses are greater than 25 percent and agricultural land uses are less

than or equal to 15 percent
Undeveloped

Undeveloped land uses are equal to or greater than 85 percent

Mixed

No dominant land use

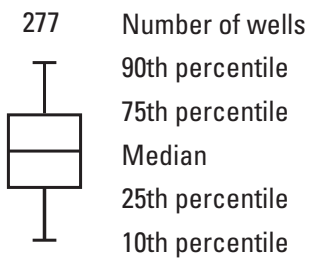

Statistical group from Tukey's test Groups with the same letter are A not significantly different at an alpha value of 0.05

Figure 16. Distribution of sodium and chloride concentrations in water samples collected from public-supply and domestic wells in New England crystalline rock aquifers, by categories of land use, 1995-2007.

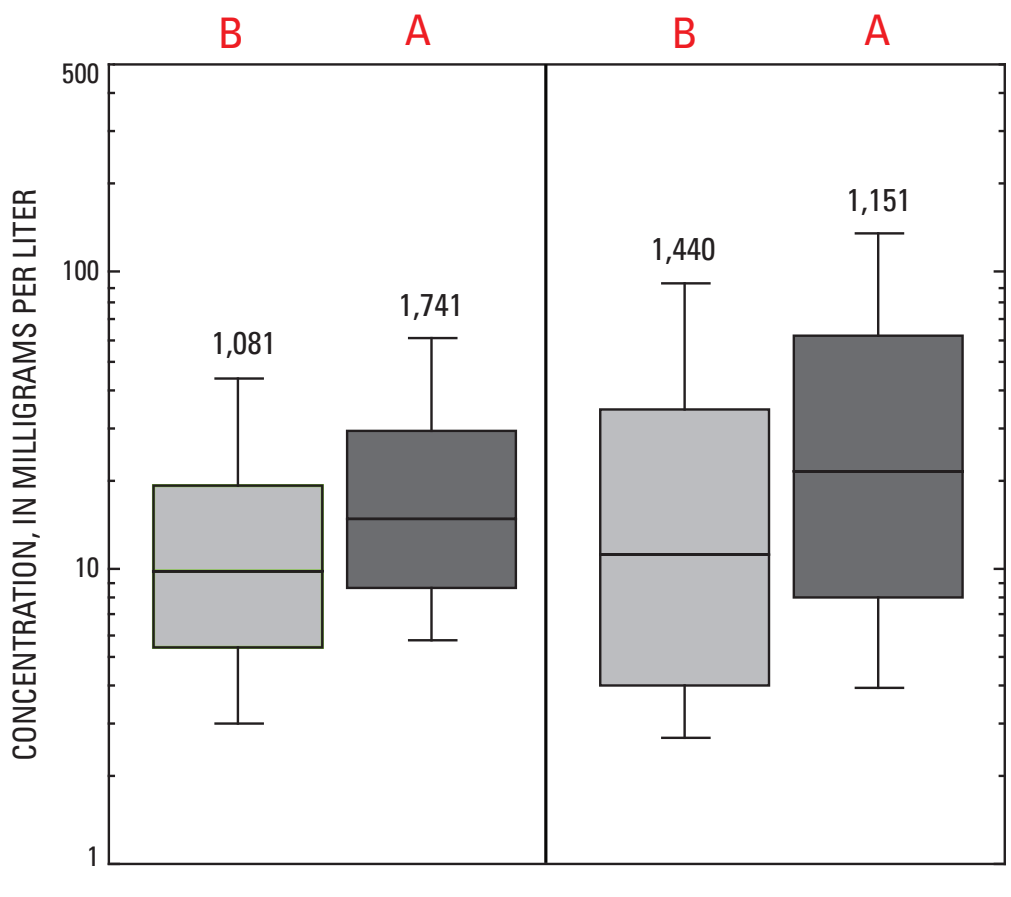

\section{EXPLANATION}

Population density within a 500-meter radius of sampled wells, in 2000

Fewer than 50 persons per square kilometer

Equal to or more than 50 persons per square kilometer

1,081 Number of wells

T 90th percentile

75th percentile

Median

25th percentile

10th percentile

Statistical group from Tukey's test

A Groups with the same letter are not significantly different at an alpha value of 0.05

Figure 17. Distribution of sodium and chloride concentrations in water samples collected from public-supply and domestic wells in New England crystalline rock aquifers, by categories of population density, 1995-2007. 
density $\left(<50\right.$ persons $\left./ \mathrm{km}^{2}\right)$ had the lowest concentrations (figs. 16-17). Chloride concentrations correlated with a wide variety of water-quality constituents and land-use variables (appendix 5). The positive correlations of $\mathrm{Na}$ and $\mathrm{Cl}$ concentrations with each other and with the percentage of developed lands and population density surrounding the wells probably reflect the influence of applied road salt to New England and New Jersey roadways and to other paved surfaces during the winter months (Mullaney and others, 2009).

The widespread rise of $\mathrm{NaCl}$ in surface water and groundwater in northern areas of the United States, where road salt is applied to paved roadways as a deicing agent, is a growing concern over the future quality of drinking water and the potential negative effect on human health (New Hampshire Department of Environmental Services, 1996). Road salt, which consists primarily of mined $\mathrm{NaCl}$ and trace amounts of other constituents, has been identified as a primary source of $\mathrm{Cl}$ in streams and groundwater (Mullaney and others, 2009). Roadways in the northeastern parts of the United States receive up to $24,000 \mathrm{~kg} / \mathrm{km}^{2} / \mathrm{yr}$ of road salt, the greatest amount in the nation (Panno and others, 2005). Road salt can enter drinking-water supplies by migrating through soil into groundwater or by runoff and drainage directly into surface water. Susceptibility of freshwaters to increased $\mathrm{NaCl}$ depends on many factors: intensity and duration of salting, overburden type and thickness, climate, road density, topography, and volume and dilution of water. Additional factors in fractured bedrock may be the extent and direction (horizontal versus vertical) to which the fractures are connected to the land surface (Harte and others, 2008).

Ratios of chloride to bromide ( $\mathrm{Cl}: \mathrm{Br})$ in water have been used to deduce the likely sources that contribute $\mathrm{NaCl}$ to groundwater (Davis and others, 1998; Stober and Bucher, 1999; Snow and others, 1990). NaCl, or "salt," in its pure form has a molar ratio of sodium to chlorine $(\mathrm{Na}: \mathrm{Cl})$ equal to 1. $\mathrm{Cl}: \mathrm{Br}$ mass ratios in water samples from the domestic wells relative to $\mathrm{Cl}$ concentrations, molar ratios of $\mathrm{Na}: \mathrm{Cl}$, and $\mathrm{pH}$ are shown in figure 18. Water samples with $\mathrm{Cl}$ concentrations less than $6 \mathrm{mg} / \mathrm{L}$ and $\mathrm{Cl}: \mathrm{Br}$ mass ratios below 200 probably reflect local precipitation sources and water-rock weathering (fig. 18A). The $\mathrm{Ca}-\mathrm{HCO}_{3}$ type water samples have a wide range of $\mathrm{Cl}: \mathrm{Br}$ mass ratios, and $\mathrm{Cl}: \mathrm{Br}$ mass ratios increase as $\mathrm{Cl}$ concentrations increase (fig. 18A). The $\mathrm{Ca}-\mathrm{HCO}_{3}$ type water samples also have a wide range of $\mathrm{Na}: \mathrm{Cl}$ molar ratios (fig. 18B) and variable pH (fig. 18C). Therefore, a mixture of recently recharged groundwaters (diluted precipitation) that are affected by variable degrees of road salt dissolution and water-rock weathering may dominate the $\mathrm{Ca}-\mathrm{HCO}_{3}$ water types.

Waters affected by road salt have $\mathrm{Cl}: \mathrm{Br}$ mass ratios more than 1,000 (Davis and others, 1998; Stober and Bucher, 1999). The $\mathrm{Ca}-\mathrm{Cl}$ and $\mathrm{Na}-\mathrm{Cl}$ type water samples generally have $\mathrm{Cl}: \mathrm{Br}$ mass ratios greater than $1,000, \mathrm{Cl}$ concentrations greater than $30 \mathrm{mg} / \mathrm{L}, \mathrm{Na}: \mathrm{Cl}$ molar ratios less than 1 , and variable $\mathrm{pH}$ (figs. 18A-C). These data indicate a mixture of groundwaters with differing alkali and halogen characteristics and with anthropogenic contaminants, such as road salt and discharges from water softeners. Two samples of $\mathrm{Na}-\mathrm{Cl}$ type water have $\mathrm{Cl}: \mathrm{Br}$ mass ratios in the seawater/connate water range of 200 to 400 , high $\mathrm{pH}(>8)$, and $\mathrm{Na}: \mathrm{Cl}$ molar ratios approximately equal to 1 (figs. $18 \mathrm{~A}-\mathrm{C}$ ), indicating that seawater aerosols from ocean storms might be a possible source of $\mathrm{NaCl}$ in these samples.

A few samples of $\mathrm{Na}-\mathrm{HCO}_{3}$ type water with high $\mathrm{pH}(>8)$ and $\mathrm{Cl}: \mathrm{Br}$ mass ratios in the seawater/connate water range (fig. 18A) were found in areas similar to those described by Tepper (1980) and in areas where bedrock groundwater may still contain remnant seawater (Snow and others, 1990; Ayotte and others, 2003) (fig. 14). These water samples also may reflect ion exchange of $\mathrm{Ca}$ for $\mathrm{Na}$ where $\mathrm{Na}$-enriched aquifer materials are in equilibrium with calcite, as indicated by $\mathrm{Na}: \mathrm{Cl}$ molar ratios greater than 1 (fig. 18B).

\section{Fluoride}

Fluoride (F) concentrations in water samples from 2,167 domestic and public-supply wells were mostly in the range of $<0.2$ to $1.7 \mathrm{mg} / \mathrm{L}$, with a median concentration of $0.3 \mathrm{mg} / \mathrm{L}$ (table 8). The maximum F concentration was $17.9 \mathrm{mg} / \mathrm{L}$ (table 8). The spatial distribution of $\mathrm{F}$ concentrations in the domestic and public-supply wells is illustrated in figure 19 .

Fluoride is the only major anion that has an enforceable drinking-water standard. The USEPA SMCL and MCL for $\mathrm{F}$ in drinking water are 2 and $4 \mathrm{mg} / \mathrm{L}$, respectively. Fluoride has both beneficial and detrimental effects on human health. At excessive exposure to $\mathrm{F}$ in drinking water (greater than $2.0 \mathrm{mg} / \mathrm{L}$ ) or in combination with exposure to $\mathrm{F}$ from other sources, adverse effects, ranging from mild dental fluorosis to crippling skeletal fluorosis, can occur as the level and period of exposure increases (World Health Organization, 2004). Water samples from 1.4 percent of 2,167 domestic and publicsupply wells had F concentrations that were equal to or greater than the MCL, and 7.5 percent of the samples had F concentrations equal to or greater than the SMCL (table 9).

Fluoride concentrations in this study were significantly (and statistically) different when the water samples were evaluated on the basis of well-construction categories, water use, and location of wells within a lithology group. Fluoride concentrations were significantly greater in samples from the public-supply wells than in samples from the domestic wells. Fluoride concentrations also were significantly greater in water samples from deep wells with long casing lengths (well depths $\geq 300 \mathrm{ft}$ and casing lengths $\geq 50 \mathrm{ft}$ ) than in any of the other three well-construction categories studied. In general, the public-supply wells are completed at deeper depths and have longer casing lengths than the domestic wells and might be one explanation for the differences in F concentrations between these two groups of wells.

Fluoride concentrations also were significantly greater in water samples from wells completed in felsic igneous rocks than from wells completed in mafic igneous and metamorphic rocks or metasedimentary rocks (fig. 20A). Wells in the 


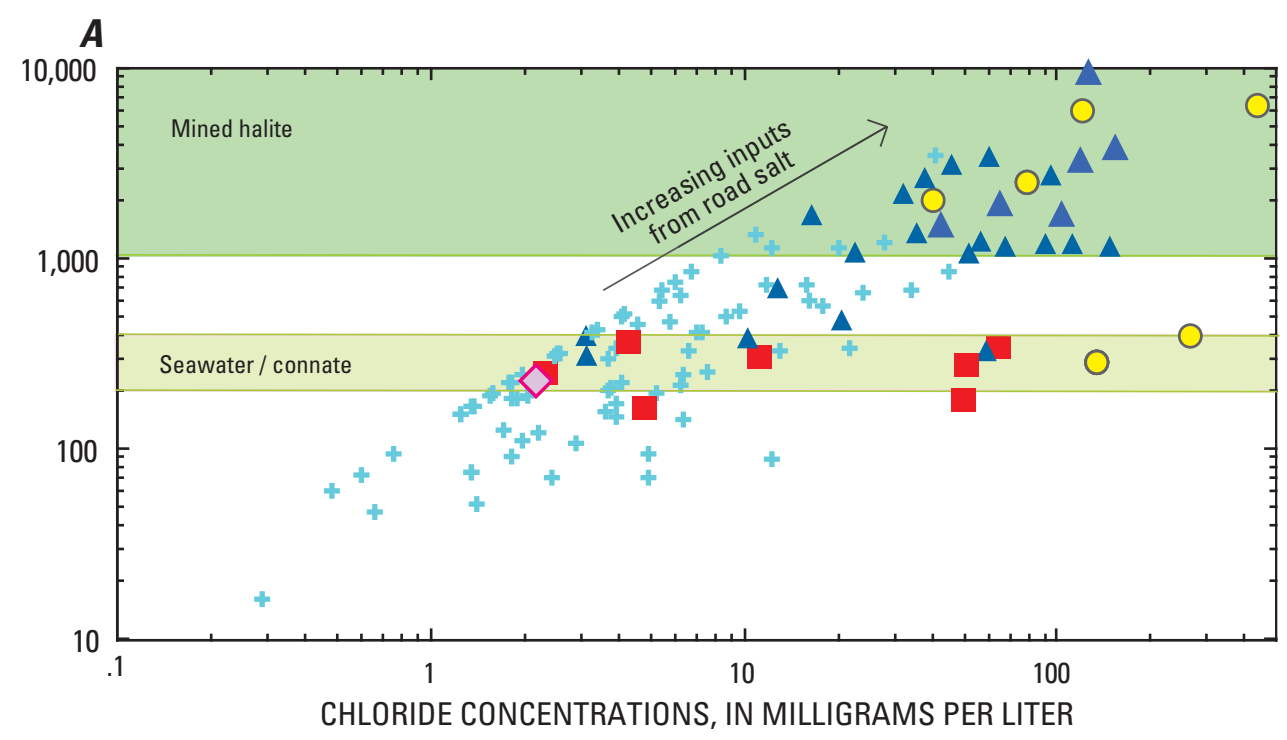

\section{EXPLANATION}

Dominant water type (cation - anion)
* $\mathrm{Ca}-\mathrm{HCO}_{3}$
$\triangle \mathrm{Ca}-\mathrm{Cl}$
$\mathrm{Na}-\mathrm{HCO}_{3}$
O $\mathrm{Na}-\mathrm{Cl}$
$\diamond \mathrm{Na}^{-} \mathrm{SO}_{4}$
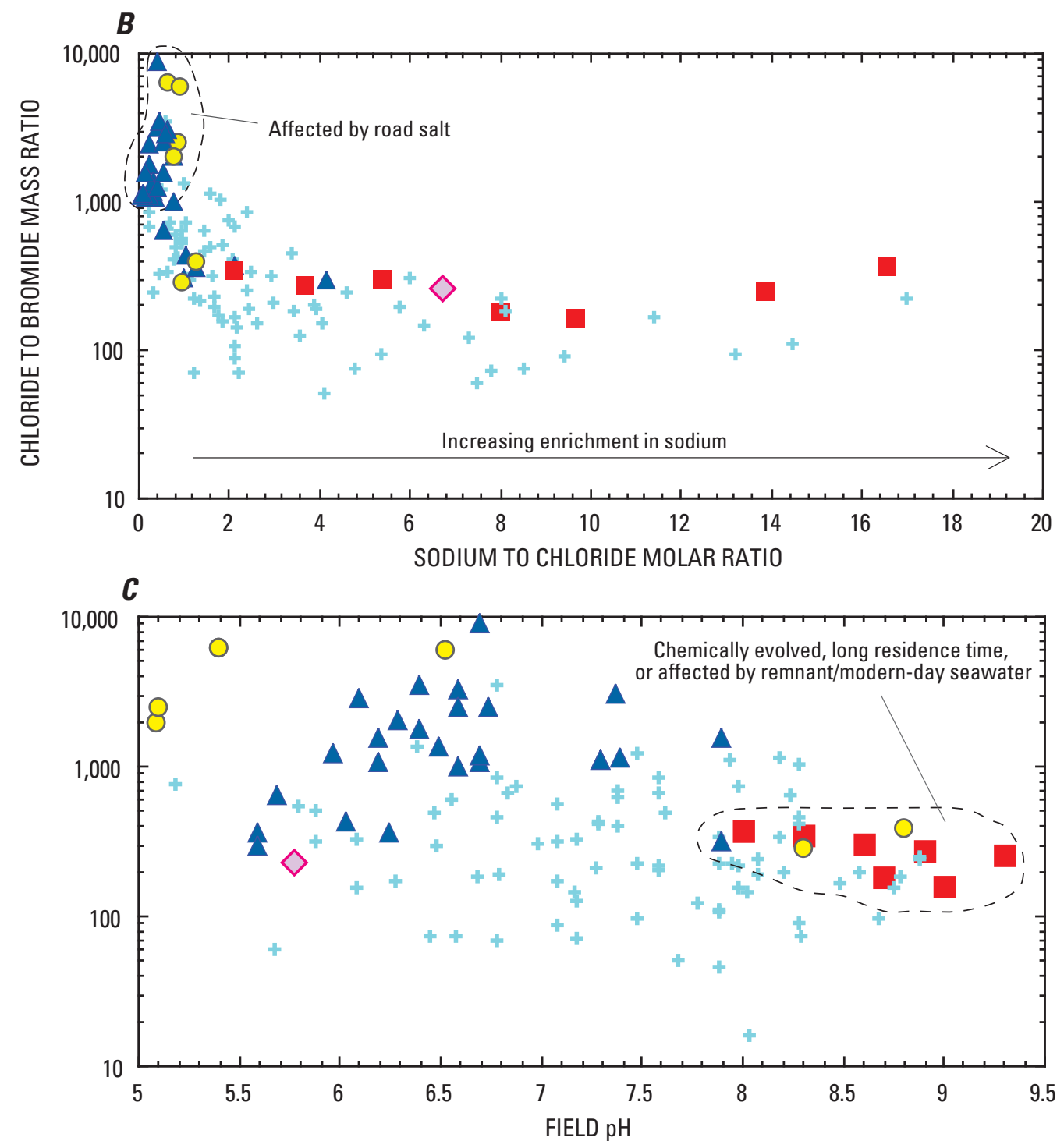

Figure 18. Chloride to bromide mass ratios in relation to $A$, chloride concentrations, $B$, sodium to chloride molar ratios, and $C$, pH in water samples collected from domestic wells in New England crystalline rock aquifers, 1995-2000. Sodium to chloride ratios greater than 20 are not shown. $\left(\mathrm{Ca}-\mathrm{HCO}_{3}\right.$, calcium-bicarbonate type water; $\mathrm{Ca}-\mathrm{Cl}$, calcium-chloride type water; $\mathrm{Na}-\mathrm{HCO}{ }_{3}$, sodium-bicarbonate type water; $\mathrm{Na}-\mathrm{Cl}$, sodium-chloride type water; $\mathrm{Na}-\mathrm{SO}_{4^{\prime}}$ sodium-sulfate type water) 


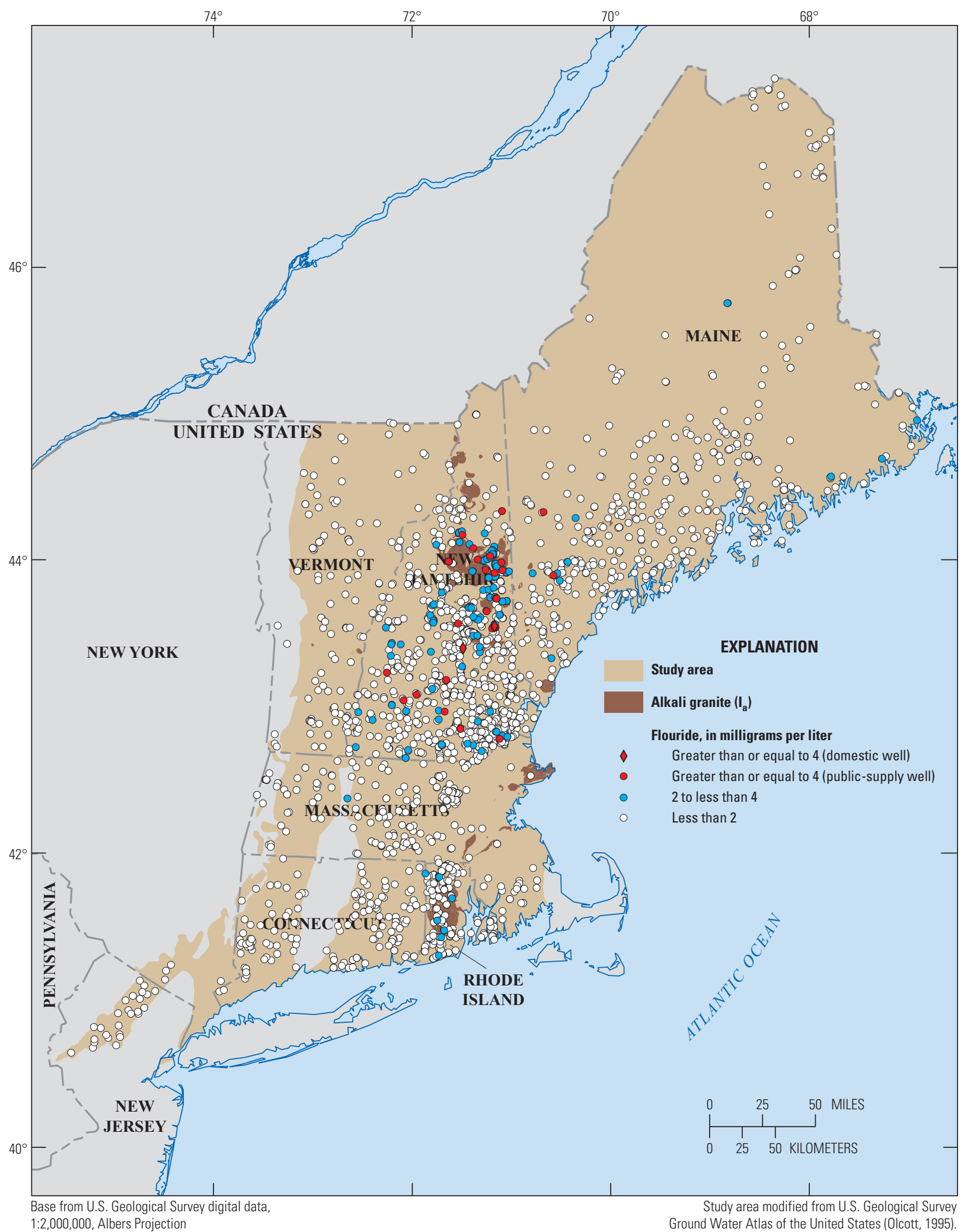

Figure 19. Spatial distribution of fluoride concentrations in water samples collected from domestic and public-supply wells in New England crystalline rock aquifers, 1995-2007. The alkali granite $\left(I_{a}\right)$ lithology group is described in detail in table 7. 


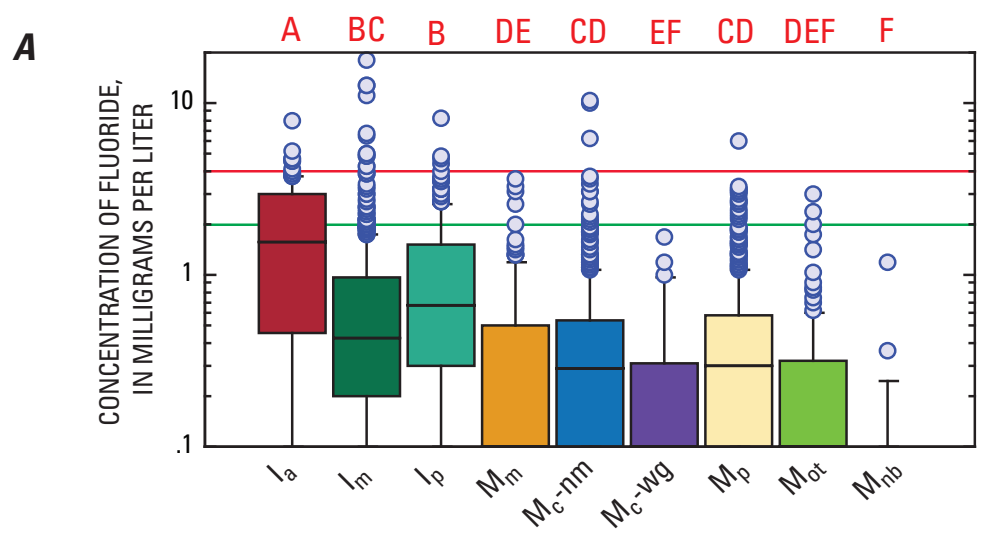

Lithology groups

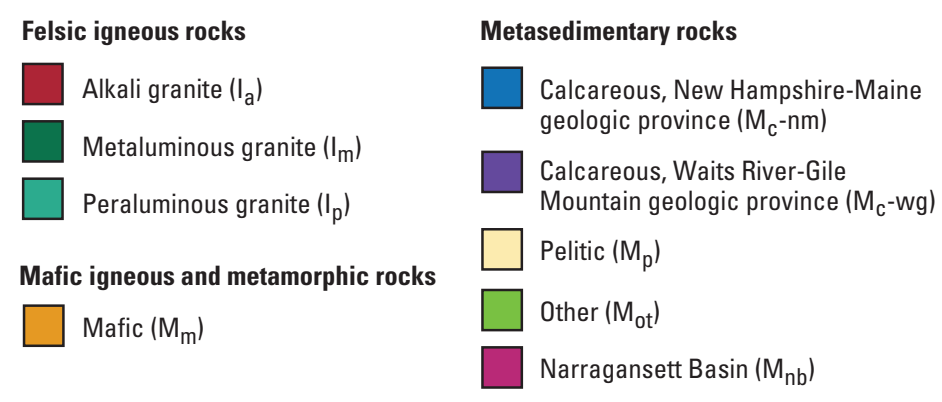

\section{$\boldsymbol{B}$}
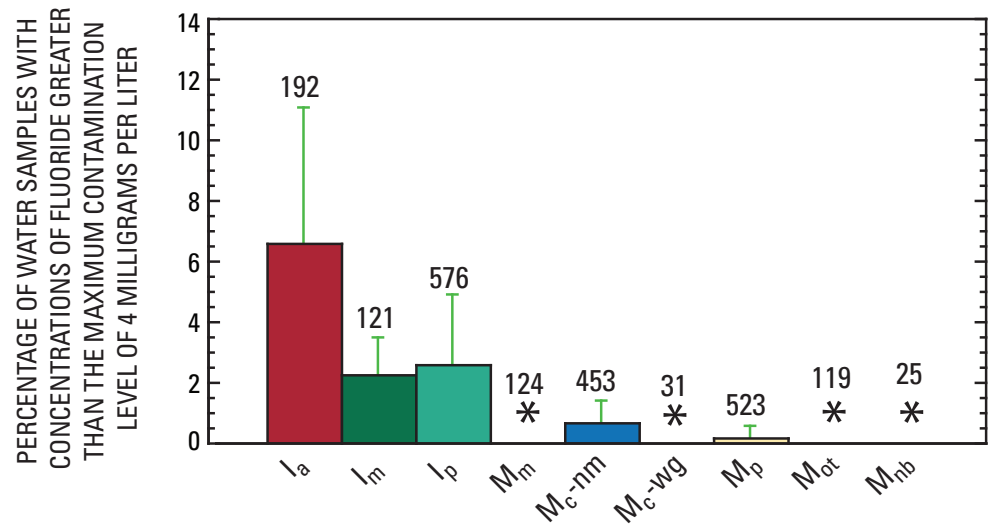

\section{EXPLANATION}

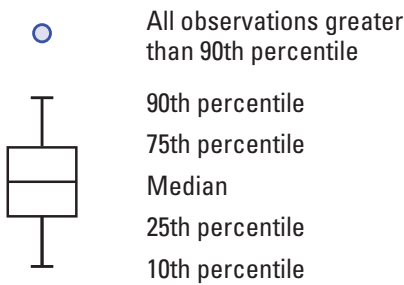

U.S. Environmental Protection Agency maximum contaminant level

U.S. Environmental Protection Agency secondary maximum contaminant level

Statistical group from Tukey's test Groups with the same letter are not significantly different at an alpha value of 0.05

\section{EXPLANATION}

192 Number of samples

Error bar representing the

95-percent confidence

interval of the mean

(binomial distribution)

* Zero percent

Figure 20. Distribution of $A$, concentrations of fluoride in water samples collected from public-supply and domestic wells in New England crystalline rock aquifers and $B$, percentages of these samples with concentrations of fluoride greater than the U.S. Environmental Protection Agency maximum contaminant level of 4 milligrams per liter, by lithology group, 1995-2007. The lithology groups are described in detail in table 7 and illustrated in figure 5B. 
alkali granite ( $\mathrm{I}_{\mathrm{a}}$ ) lithology group had the largest percentage of samples with F concentrations greater than the MCL (6.6 percent), followed by wells in the peraluminous granite ( $\left.\mathrm{I}_{\mathrm{p}}\right)$ group at 2.6 percent, and by wells in the metaluminous granite $\left(\mathrm{I}_{\mathrm{m}}\right)$ group at 2.3 percent (fig. 20B). All other studied lithology groups had less than 1 percent of water samples with F concentrations exceeding the MCL (fig. 20B). In a recent study of crystalline rock aquifers in New Hampshire, Moore (2004) found that 3 percent of samples from 527 domestic bedrock wells completed in felsic igneous rocks exceeded the MCL for F, while none of the samples from 71 domestic bedrock wells completed in calcareous metasedimentary rocks exceeded the MCL.

Most fluoride-bearing minerals, such as fluorite, apatite, mica, and hornblende are relatively insoluble in water (Murray, 1986). Fluorite $\left(\mathrm{CaF}_{2}\right)$, a common F mineral of low solubility, occurs in both igneous and sedimentary rocks. Hitchcock (1878) reported that large crystals of $\mathrm{CaF}_{2}$ are found in the White Mountains of New Hampshire, an area that is primarily classified in this study as belonging to the I lithology group (fig. 19). From the data collected for this study, the highest four concentrations of $F$ (11.1 to $17.9 \mathrm{mg} / \mathrm{L})$ were from water samples in wells completed in the Winnipesaukee Tonalite Formation in New Hampshire (appendix 6). Winnipesaukee Tonalite, a geologic bedrock unit in the $\mathrm{I}_{\mathrm{m}}$ lithology group, varies from diorite to granodiorite and granite and contains biotite as the major fluorine-bearing mafic mineral.

Edmunds and Smedley (1996) and Frengstad and others (2001) note that F concentrations can increase in groundwaters in which cation exchange occurs. In this study, four of the seven $\mathrm{Na}-\mathrm{HCO}_{3}$ water-type samples, where cation exchange of $\mathrm{Ca}$ for $\mathrm{Na}$ has likely occurred, have $\mathrm{F}$ concentrations greater than $1 \mathrm{mg} / \mathrm{L}$. Interestingly, the samples from two domestic wells in New Hampshire with unusually high $\mathrm{CH}_{4}$ concentrations also had high $\mathrm{F}$ concentrations $(>6 \mathrm{mg} / \mathrm{L})$ and were $\mathrm{Na}-\mathrm{HCO}_{3}$ type water, even though the wells are not in the area affected by the postglacial marine inundation where cation exchange may be significant (fig. 14).

Fluoride concentrations in samples from the domestic wells correlated positively with field $\mathrm{pH}$ and $\mathrm{Na}$ and correlated inversely with $\mathrm{CO}_{2}$ gas, $\mathrm{DO}, \mathrm{NO}_{3}$, and $\mathrm{Ca}$ (appendix 7). Fluoride concentrations in samples from the public-supply wells correlated positively with $\mathrm{pH}$, well depth, and $\mathrm{Na}$, and also correlated positively with $U$ concentrations in streambed-sediment samples collected in New England for the National Uranium Resources Evaluation (NURE) Program (appendix 7). These correlations and the spatial pattern of $\mathrm{F}$ concentrations shown in figure 19 indicate that high $\mathrm{F}$ concentrations in NECR aquifers are related to F-bearing rock minerals in felsic igneous rocks and to chemically evolved, high $\mathrm{pH}$ groundwaters with low concentrations of Ca. Studies from other countries have shown that high $\mathrm{F}$ concentrations occur under similar conditions (Frengstad and others, 2001; Chae and others, 2006; Mondal and others, 2009; Rafique and others, 2009).

\section{Trace Elements}

With the exception for Fe and Mn, trace elements described in this section include metals and semimetallic elements that typically are found in fresh waters at concentrations less than $1 \mu \mathrm{g} / \mathrm{L}$. All trace elements originate primarily from rock weathering, and their concentrations in groundwater reflect their presence and abundance in aquifer materials, geochemical (reduction-oxidation potential) conditions, $\mathrm{pH}$, residence time, and ability to precipitate from or dissolve in water (Hem, 1985). Many trace elements occur in groundwater at multiple oxidation states and, depending on geochemical conditions and $\mathrm{pH}$, have different solubility characteristics. Some trace elements can be derived from anthropogenic sources, such as those present as trace contaminants in pesticides, fertilizers and road salt. Materials used for construction of wells, pumps, spigots, and water distribution lines may have components that contain leachable amounts of $\mathrm{Cu}, \mathrm{Zn}$, or $\mathrm{Pb}$. Mining activities, waste disposal, and leachate migration from landfills and septic systems also can contribute or affect concentrations of trace elements in groundwater.

The trace elements cobalt, silver, and thallium were not measureable at concentrations greater than their respective LRLs in any of the water samples collected from the domestic wells (appendixes 1-2). The trace elements antimony (Sb), beryllium $(\mathrm{Be})$, cadmium $(\mathrm{Cd})$, selenium $(\mathrm{Se})$, and vanadium (V) were measured at concentrations greater than $1 \mu \mathrm{g} / \mathrm{L}$ in less than 10 percent of the water samples from the domestic wells (appendixes 1-2). The trace elements Al, As, barium $(\mathrm{Ba})$, boron $(\mathrm{B}), \mathrm{Cu}$, chromium $(\mathrm{Cr}), \mathrm{Fe}, \mathrm{Pb}$, lithium (Li), Mn, molybdenum (Mo), nickel (Ni), strontium (Sr), U, and $\mathrm{Zn}$ were measured at concentrations greater than $1 \mu \mathrm{g} / \mathrm{L}$ in 10 percent or more of the samples from the domestic wells (appendixes 1-2). Values for correlations of the concentrations of trace elements in water samples from the domestic wells with physiochemical properties and chemical constituents, by use of Spearman correlation, are provided in table 11. The following sections discuss in more detail some of the traceelement constituents analyzed in the water samples from the domestic and public-supply wells.

\section{Iron and Manganese}

Iron and Mn concentrations were highly variable in water samples from this study. Iron concentrations in water samples from 1,632 domestic and public-supply wells were mostly in the range of $<50$ to $905 \mu \mathrm{g} / \mathrm{L}$, with a median concentration of $77 \mu \mathrm{g} / \mathrm{L}$ (table 8). Manganese concentrations in water samples from 1,759 domestic and public-supply wells were mostly in the range of $<20$ to $226 \mu \mathrm{g} / \mathrm{L}$, with a median concentration of $30 \mu \mathrm{g} / \mathrm{L}$ (table 8). The maximum Fe $(100,000 \mu \mathrm{g} / \mathrm{L})$ and $\mathrm{Mn}$ $(3,420 \mu \mathrm{g} / \mathrm{L})$ concentrations, in samples collected from publicsupply wells, show that their concentrations can be considerable in NECR aquifers (table 8). The spatial distribution of Mn concentrations in water samples collected from the domestic and public-supply wells is illustrated in figure 21 . 


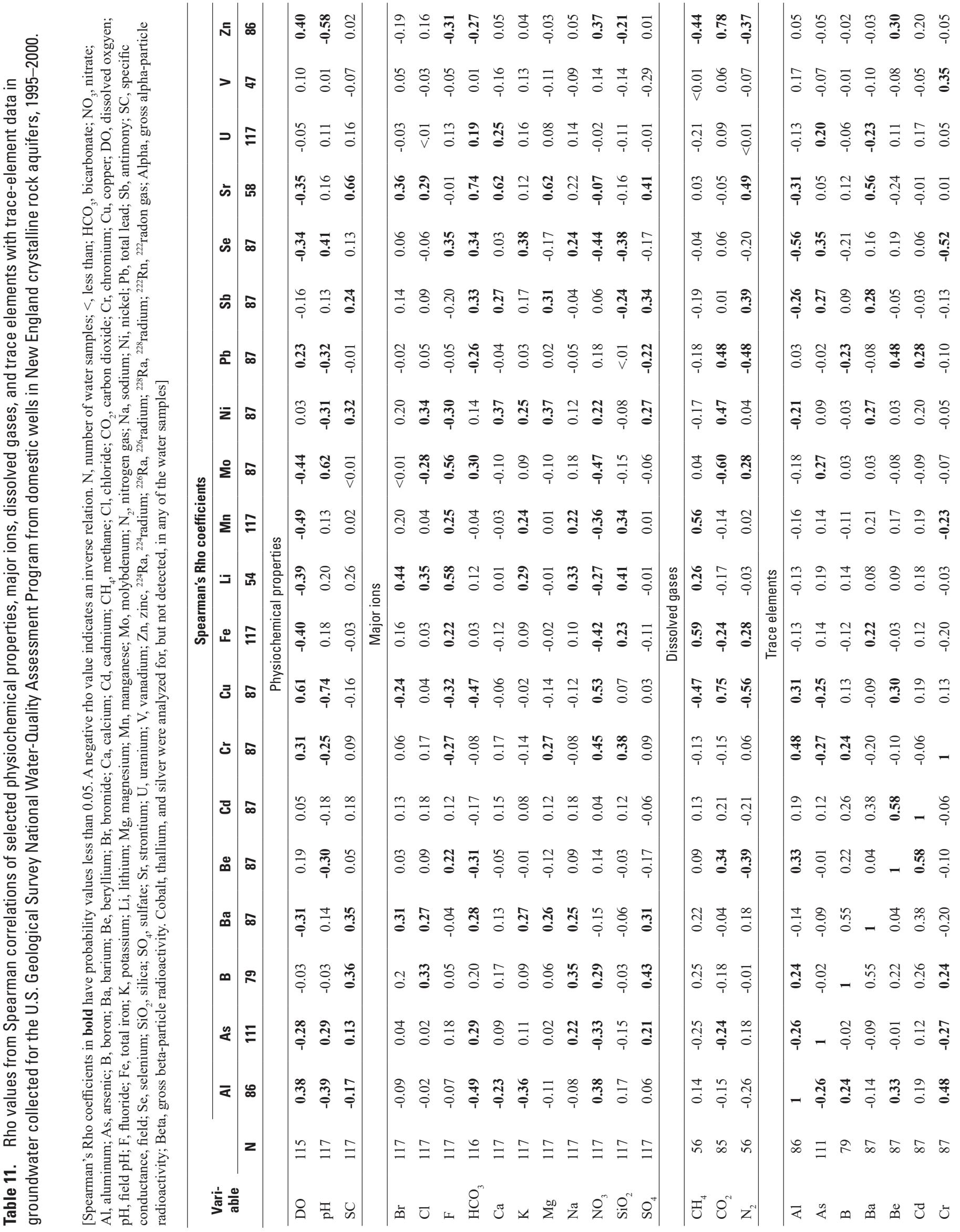




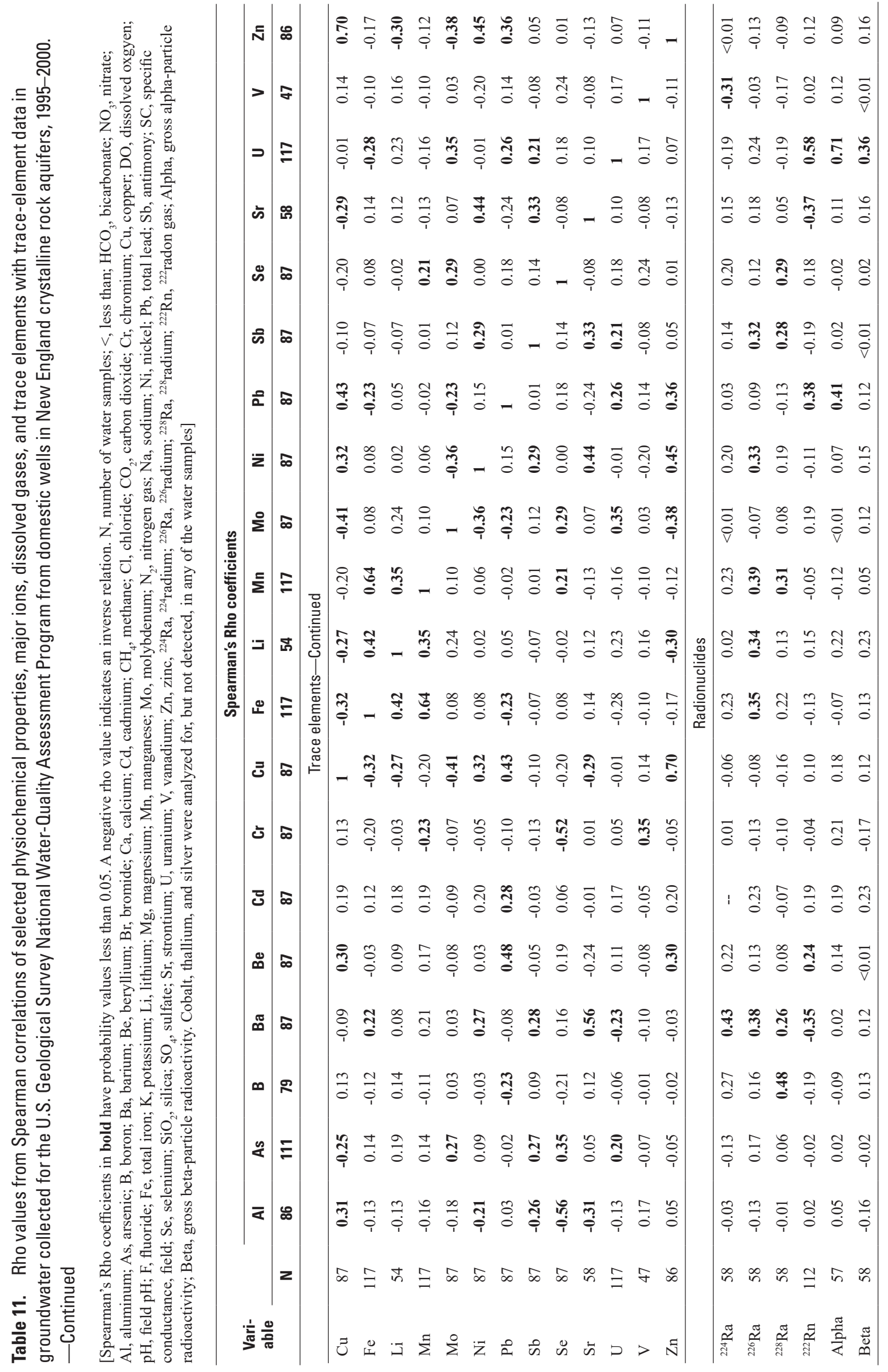




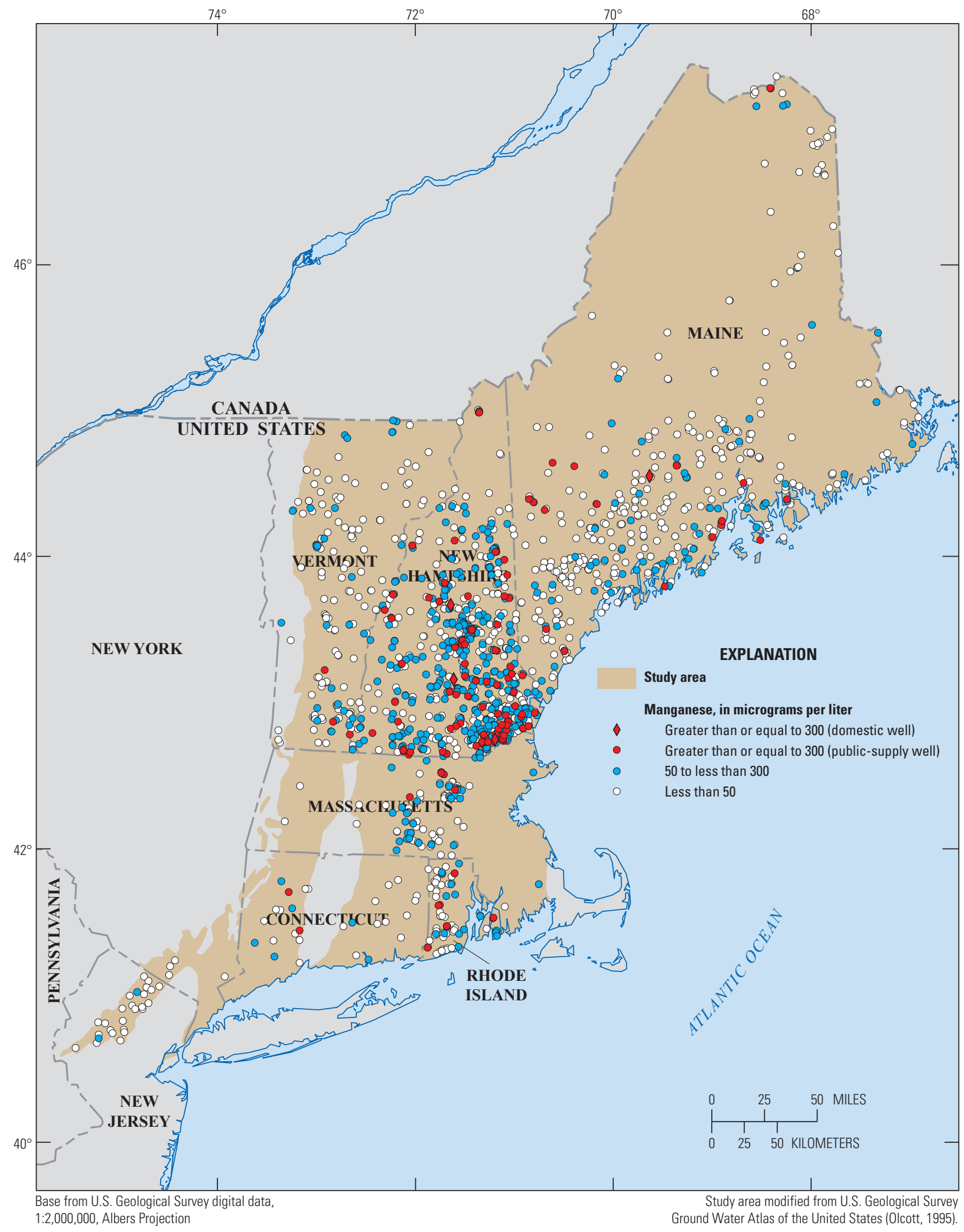

Figure 21. Spatial distribution of manganese concentrations in water samples collected from domestic and public-supply wells in New England crystalline rock aquifers, 1995-2007. 
Iron and $\mathrm{Mn}$ are trace elements essential for human health, but Mn may have adverse neurological effects at high doses (Agency for Toxic Substances and Disease Registry, 2008); therefore, USEPA has issued a lifetime health advisory (LHA) of $300 \mu \mathrm{g} / \mathrm{L}$ for Mn. Manganese concentrations were equal to or greater than the LHA in 7.3 percent of the water samples from the domestic and public-supply wells (table 9). The recommended SMCLs for Fe $(300 \mu \mathrm{g} / \mathrm{L})$ and $\mathrm{Mn}$ $(50 \mu \mathrm{g} / \mathrm{L})$ were established primarily to avoid aesthetic nuisances, such as staining of laundry and of plumbing fixtures. Iron concentrations were equal to or greater than the SMCL in 22 percent of the water samples, and Mn concentrations were equal to or greater than the SMCL in 38 percent of the water samples from domestic and public-supply wells (table 9).

Iron and Mn concentrations in this study were not significantly different when the samples were evaluated on the basis of land use, population density, or well-construction categories. However, concentrations of $\mathrm{Fe}$ and $\mathrm{Mn}$ were significantly different among some of the geologic lithology groups. In comparing $\mathrm{Fe}$ and $\mathrm{Mn}$ concentrations among the nine lithology groups, water samples from wells in the $\mathrm{M}_{\mathrm{nb}}$ lithology group ranked the highest, while water samples from wells in the $\mathrm{M}_{\mathrm{c}}$-wg lithology group ranked the lowest. There were no significant differences in $\mathrm{Fe}$ and $\mathrm{Mn}$ concentrations among the remaining seven lithology groups studied.

Iron and $\mathrm{Mn}$ concentrations were significantly greater in the public-supply well samples than in the domestic well samples. Iron concentrations were greater than the SMCL $(300 \mu \mathrm{g} / \mathrm{L})$ in 24 percent of the public-supply well samples, whereas only 6.8 percent of the domestic well samples had $\mathrm{Fe}$ concentrations greater than the SMCL (table 9). Manganese concentrations were greater than the SMCL $(50 \mu \mathrm{g} / \mathrm{L})$ in 39 percent of the public-supply well samples, whereas only 17 percent of the domestic well samples had Mn concentrations greater than the SMCL (table 9). It is possible that this difference in $\mathrm{Fe}$ and $\mathrm{Mn}$ concentrations between the publicsupply and domestic wells could be related to the difference in sample processing (domestic well samples were filtered, whereas the public-supply well samples were unfiltered). The difference in pumping rates for the public-supply and domestic wells is another possible explanation for the differences in $\mathrm{Fe}$ and $\mathrm{Mn}$ concentrations between the two data programs. Larger and more sustained pumping rates in the public-supply wells may result in greater mixing of groundwater from different fractures or induce water from other sources (such as overlying glacial aquifers or surface water), which in turn, changes geochemical conditions and (or) groundwater-flow patterns in ways that enhances the solubility and mobility of Fe and $\mathrm{Mn}$ to pumped groundwater.

Iron and Mn solubility increases as DO decreases. As such, DO concentrations in the water samples from the domestic wells correlated inversely with concentrations of $\mathrm{Fe}$ and $\mathrm{Mn}$ (table 11). While Fe and Mn concentrations in the domestic well samples were not correlated with $\mathrm{pH}$, they were strongly and positively correlated with each other (table 11) and with apparent residence time (appendix 4). Iron and Mn concentrations in the public-supply well samples were also strongly and positively correlated with each other $($ rho $=0.54$, $p$-value $=<0.0001, \mathrm{n}=1,373)$, suggesting that $\mathrm{Fe}$ and $\mathrm{Mn}$ commonly co-occur in NECR aquifers and some of the largest concentrations may be associated with older groundwaters.

\section{Aluminum, Barium, and Strontium}

Concentrations of $\mathrm{Al}$ greater than $1 \mu \mathrm{g} / \mathrm{L}$ were measured in 57 percent of 86 domestic well samples, although there may be a positive bias due to contamination in some of the blank samples (table 3). High concentrations of Al in drinking water can result in undesirable color and turbidity (World Health Organization, 2004), and the USEPA recommends that concentrations not exceed 50 to $200 \mu \mathrm{g} / \mathrm{L}$. Concentrations of $\mathrm{Al}$ greater than $50 \mu \mathrm{g} / \mathrm{L}$ occurred in 3 of the domestic well samples. Aluminum concentrations in water samples from the domestic wells correlated positively with DO concentrations and correlated inversely with $\mathrm{pH}$ (table 11). Aluminum-rich clays and colloids produced by rock weathering of aluminosilicate minerals, such as feldspars, micas, and other related minerals, are relatively insoluble in groundwater, but high $\mathrm{Al}$ concentrations can occur under very low $\mathrm{pH}$ conditions (Hem, 1985). The three highest Al concentrations (140 to $360 \mu \mathrm{g} / \mathrm{L}$ ) were measured in water samples under very low $\mathrm{pH}(<5.7)$ and oxic conditions ( $\mathrm{DO}>2.8 \mathrm{mg} / \mathrm{L}$ ), and were from wells completed in felsic igneous rocks.

Barium and Sr are alkaline-earth elements that vary widely in their abundance and behavior in groundwater (Hem, 1985). Concentrations of Ba greater than $1 \mu \mathrm{g} / \mathrm{L}$ were measure in 85 percent of 87 domestic well samples (table 8 ). Concentrations of $\mathrm{Sr}$ greater than $1 \mu \mathrm{g} / \mathrm{L}$ were detected in all 58 domestic well samples (appendix 1). The maximum Ba concentration $(113.8 \mu \mathrm{g} / \mathrm{L})$ was well below the MCL of $2,000 \mu \mathrm{g} / \mathrm{L}$ and the maximum $\mathrm{Sr}$ concentration $(1,660 \mu \mathrm{g} / \mathrm{L})$ was below the LHA of 4,000 $\mu \mathrm{g} / \mathrm{L}$ (table 9). DeSimone (2009) reported that the highest $\mathrm{Sr}$ concentrations in domestic wells nationally occurred more frequently in the southwestern and south-central United States. Barium concentrations in the domestic well samples correlated positively with $\mathrm{Sr}, \mathrm{K}$, and $\mathrm{Mg}$ concentrations, and with ${ }^{224} \mathrm{Ra},{ }^{226} \mathrm{Ra}$, and ${ }^{228} \mathrm{Ra}$ activities (table 11). A study of a NECR aquifer in western Vermont also has shown an association between $\mathrm{Ba}$ and Ra concentrations (North, 2005). Strontium concentrations in the domestic well samples correlated positively with $\mathrm{Ca}$ and $\mathrm{Mg}$ (table 12). Strontium in groundwater can occur at higher concentrations in calcareous and calc-pelite rocks than in other rock lithologies because $\mathrm{Sr}$ geochemistry is similar to that of $\mathrm{Ca}$, whereas $\mathrm{Ba}$ geochemistry is similar to that of $\mathrm{K}$ and $\mathrm{Ra}$ and occurs at similar concentrations among lithology groups.

\section{Boron, Lithium, and Molybdenum}

Boron concentrations in 79 domestic well samples ranged from $<12$ to $132.7 \mu \mathrm{g} / \mathrm{L}$ (table 8 ); none of the samples exceeded the LHA of 1,000 $\mu \mathrm{g} / \mathrm{L}$ (table 9). Boron in groundwater may originate from anthropogenic sources, such as 
Table 12. Arsenic occurrence in groundwater at concentrations greater than the U.S. Environmental Protection Agency Maximum Contaminant Level, by previous studies.

$[\mathrm{N}$, number of water samples; $\mu \mathrm{g} / \mathrm{L}$, micrograms per liter; --, no data; USEPA SDWA, U.S. Environmental Protection Agency Safe Drinking-Water Act Program; USGS NAWQA, U.S. Geological Survey National Water-Quality Assessment Program; Unk, unknown. The Maximum Contaminant Level (MCL) for arsenic in publicly-supplied drinking water is $10 \mu \mathrm{g} / \mathrm{L}]$

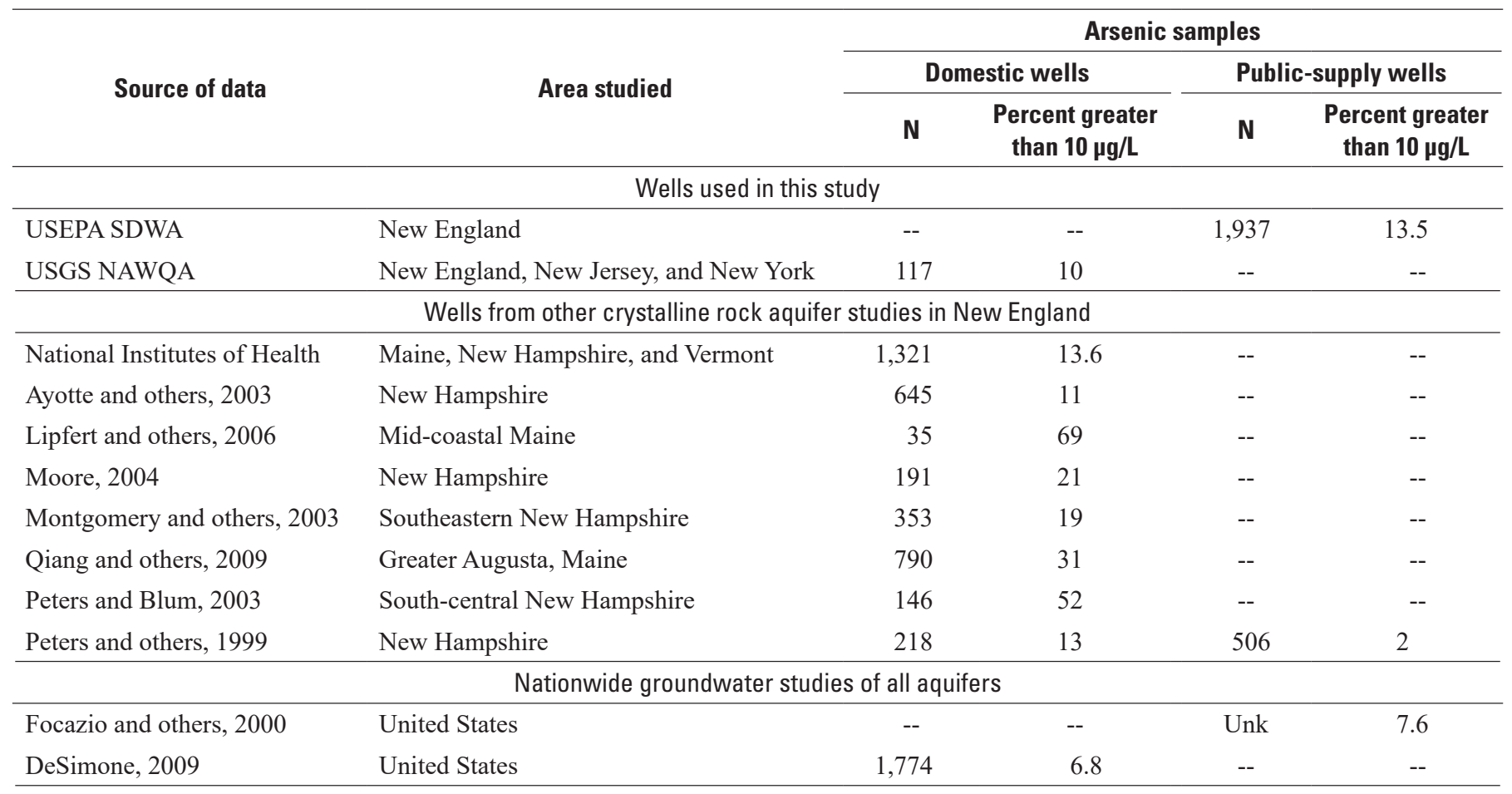

${ }^{1}$ From Debra Silverman and Dalsu Baris, National Institute of Health, written commun., 2009.

\section{References}

Ayotte, J.D., Montgomery, D.L., Flanagan, S.M., and Robinson, K.W., 2003, Arsenic in groundwater in eastern New England: Occurrence, controls, and human health implications: Environmental Science and Technology, v. 37, no. 10, p. $2075-2083$.

DeSimone, L.A., 2009, Quality of water from domestic wells in principal aquifers of the United States, 1991-2004: U.S. Geological Survey Scientific Investigations Report 2008-5227, 139 p. (Also available at http://pubs.usgs.gov/sir/2008/5227).

Focazio, M.J., Welch, A.H., Watkins, S.A., Helsel, D.R., and Horn, M.A., 2000, A retrospective analysis on the occurrence of arsenic in ground water resources of the United States and limitations in drinking-water-supply characterizations: U.S. Geological Survey Water-Resources Investigations Report 99-4279, 27 p.

Lipfert, Gail, Reeve, A.S., Sidle, W.C., and Marvinney, Robert, 2006, Geochemical patterns of arsenic-enriched ground water in fractured, crystalline bedrock, Northport, Maine, U.S.A.: Applied Geochemistry, v. 21, no. 3, p. 528-545.

Montgomery, D.L., Ayotte, J.D., Carroll, P.R., and Hamlin, Patricia, 2003, Arsenic concentrations in private bedrock wells in southeastern New Hampshire: U.S. Geological Survey Fact Sheet FS 051-03, 6 p. (Also available at http://pubs.water.usgs.gov/fs-051-03).

Moore, R.B., 2004, Quality of water in the fractured bedrock aquifer of New Hampshire: U.S. Geological Survey Scientific Investigations Report 2004-5093, 30 p. (Also available at http://pubs.usgs.gov/sir/2004/5093/pdf/SIR2004-5093.pdf)

National Institutes of Health, National Cancer Institute, Debra Silverman and Dalsu Baris, written commun., 2009.

Peters, S.C., Blum, J.D., Klaue, Bjoern, and Karagas, M.R., 1999, Arsenic occurrence in New Hampshire drinking water: Environmental Science and Technology, v. 33, no. 9, p. 1328-1333.

Peters, S.C., and Blum, J.D., 2003, The source and transport of arsenic in a bedrock aquifer, New Hampshire, U.S.A.: Applied Geochemistry, v. 18 (2003), p. 1773-1787.

Yang, Qiang, Jung, H.B., Culbertson, C.W., Marvinney, R.G., Loiselle, M.C., Lock, D.B., Cheek, Heidi, Thibodeau, Hilary, and Zheng, Yan, 2009, Spatial pattern of groundwater arsenic occurrence and association with bedrock geology in greater Augusta, Maine: Environmental Science and Technology, v. 43, p. 2714-2719. 
sewage disposal (DeSimone, 2009). Boron concentrations in water samples from the domestic wells correlated positively with $\mathrm{NO}_{3}$ (table 11), suggesting that leachate from onsite septic systems is a possible source of B in the domestic well samples.

Lithium concentrations in 54 domestic well samples were mostly in the range of 1 to $19.8 \mu \mathrm{g} / \mathrm{L}$, with a maximum concentration of $1,320 \mu \mathrm{g} / \mathrm{L}$ (appendix 1). Lithium concentrations in the water samples correlated positively with $\mathrm{Br}, \mathrm{Cl}$, $\mathrm{Na}$, and $\mathrm{F}$ and inversely with $\mathrm{DO}$ (table 11), suggesting that $\mathrm{Li}$ in NECR aquifers is associated with road salt, connate waters, or chemically evolved groundwater. The domestic well sample in this study (in New Hampshire) with the unusual Li concentration of $1,320 \mu \mathrm{g} / \mathrm{L}$ also had high concentrations of $\mathrm{F}$ $(17.9 \mathrm{mg} / \mathrm{L})$ and $\mathrm{CH}_{4}(15.5 \mathrm{mg} / \mathrm{L})$ and had high $\mathrm{pH}(8.7)$.

Molybdenum concentrations in 87 domestic well samples were mostly in the range of $<1$ to $3.8 \mu \mathrm{g} / \mathrm{L}$, with a maximum concentration of 18.8 (table 8). None of the samples exceeded the LHA of $40 \mu \mathrm{g} / \mathrm{L}$ (table 9). Molybdenum concentrations in the water samples correlated inversely with concentrations of DO and correlated positively with $\mathrm{pH}$ (table 11), indicating that Mo solubility increases as DO decreases and $\mathrm{pH}$ increases. Molybdenum concentrations also were strongly and positively correlated with apparent residence time (appendix 4), suggesting that higher Mo concentrations are associated with older NECR groundwaters.

\section{Beryllium and Chromium}

Three water samples from 57 domestic wells had measureable $\mathrm{Be}(>1 \mu \mathrm{g} / \mathrm{L})$, and one of these samples had a concentration $(7.54 \mu \mathrm{g} / \mathrm{L})$ that exceeded the USEPA MCL of $4 \mu \mathrm{g} / \mathrm{L}$ (appendix 1; table 9). Beryllium's solubility is enhanced in acidic waters. The three water samples with measureable concentrations of $\mathrm{Be}$ had low $\mathrm{pH}(<5.7)$ and were collected from wells completed in the $\mathrm{I}_{\mathrm{a}}$ and $\mathrm{I}_{\mathrm{p}}$ granite lithology groups (appendix 6). One of the most important minerals containing $\mathrm{Be}$ is beryl, a silicate of $\mathrm{Al}$ and $\mathrm{Be}$ that is found most commonly in pegmatites (Hem, 1985).

Chromium concentrations in 87 domestic well samples ranged from $<1$ to $4.1 \mu \mathrm{g} / \mathrm{L}$ (table 8 ); none of the samples exceeded the MCL of $100 \mu \mathrm{g} / \mathrm{L}$ (table 9). However, 17 of the 19 water samples with measureable $\mathrm{Cr}(>1 \mu \mathrm{g} / \mathrm{L})$ were collected from NJ-NY domestic wells (appendix 2); the remaining two samples were collected from the New England domestic wells (appendix 1). Chromium concentrations in the water samples correlated positively with concentrations of DO and inversely with $\mathrm{pH}$ (table 11), indicating that chromium mobility is enhanced in low-pH, oxic groundwaters. Water samples from the NJ-NY domestic wells had significantly lower $\mathrm{pH}$ values and higher $\mathrm{DO}$ concentrations than the New England domestic wells (fig. 7), which might explain the difference in $\mathrm{Cr}$ occurrence rates between the NJ-NY wells and the New England wells.

\section{Copper, Lead, Nickel, and Zinc}

At a common LRL of $1 \mu \mathrm{g} / \mathrm{L}, 60$ percent of water samples from 86 to 87 domestic wells had measurable $\mathrm{Cu}$, 16 percent had measurable $\mathrm{Pb}, 35$ percent had measureable $\mathrm{Ni}$, and 55 percent had measurable $\mathrm{Zn}$ (table 8). The largest concentrations for the 4 trace elements were all in water samples collected for the NECB study. The maximum $\mathrm{Pb}$ concentration $(12.9 \mu \mathrm{g} / \mathrm{L})$ was from a domestic well in Rhode Island; the maximum $\mathrm{Ni}$ concentration $(11.6 \mu \mathrm{g} / \mathrm{L})$ was from a domestic well in Maine; and the maximum $\mathrm{Cu}(416 \mu \mathrm{g} / \mathrm{L})$ and $\mathrm{Zn}$ concentrations $(463 \mu \mathrm{g} / \mathrm{L})$ were from the same domestic well in New Hampshire. Several of the associated blank samples had measureable amounts of $\mathrm{Cu}, \mathrm{Pb}$, and $\mathrm{Zn}$ (table 3), so there may be a positive bias in the total number of samples with detections above the LRL for these trace metals.

Copper, $\mathrm{Pb}$, and $\mathrm{Zn}$ solubility in water increases as $\mathrm{DO}$ increases and $\mathrm{pH}$ decreases. As such, $\mathrm{DO}$ concentrations in the water samples from the domestic wells correlated positively with concentrations of $\mathrm{Cu}, \mathrm{Pb}$, and $\mathrm{Zn}$; and $\mathrm{pH}$ correlated inversely with concentrations of $\mathrm{Cu}, \mathrm{Pb}$, and $\mathrm{Zn}$ (table 11). $\mathrm{pH}$ also correlated inversely with $\mathrm{Ni}$ concentrations. All four trace elements (except for $\mathrm{Ni}$ with $\mathrm{Pb}$ ) correlated positively with each other (table 11) and inversely with apparent residence time (appendix 4), indicating that they generally occur in NECR aquifers under oxic and low-pH conditions-for example, younger groundwater.

\section{Arsenic}

Arsenic concentrations in 2,054 water samples collected from the domestic and public-supply wells were mostly in the range of $<5$ to $13 \mu \mathrm{g} / \mathrm{L}$, with a median value of $<5 \mu \mathrm{g} / \mathrm{L}$ (table 8). The largest As concentration in a domestic well sample (in Maine) was $50.9 \mu \mathrm{g} / \mathrm{L}$, and the largest As concentration in a public-supply well sample (in Maine) was $2,400 \mu \mathrm{g} / \mathrm{L}$. The spatial distribution of As concentrations in these samples is shown in figure 22. Many of the higher concentrations (As $\geq 10 \mu \mathrm{g} / \mathrm{L}$ ) coincide with areas classified as calcareous metasedimentary rocks in eastern New Hampshire and Maine ( $\mathrm{M}_{\mathrm{c}}-\mathrm{nm}$ lithology group). Similar spatial distribution patterns of As concentrations in eastern New England has been reported on by previous studies (Ayotte and others, 1999, 2003).

Of the 2,054 water samples analyzed for arsenic in this study, 13.3 percent had concentrations equal to or greater than the MCL of $10 \mu \mathrm{g} / \mathrm{L}$ (table 9); this finding is comparable to that of an earlier study (1995-2003) on arsenic in NECR aquifers at a regional scale (Ayotte and others, 2006). In the earlier study, As concentrations equaled or exceeded the MCL in 12 percent of water samples collected from 2,470 domestic and public-supply bedrock wells in New England. Using data from these wells, Ayotte and others (2006) modeled the probability that bedrock aquifers in New England would yield groundwater with As concentrations greater than $5 \mu \mathrm{g} / \mathrm{L}$. Many of those public-supply wells analyzed by Ayotte and others (2006) also were selected for this study, therefore, similar results were expected. 


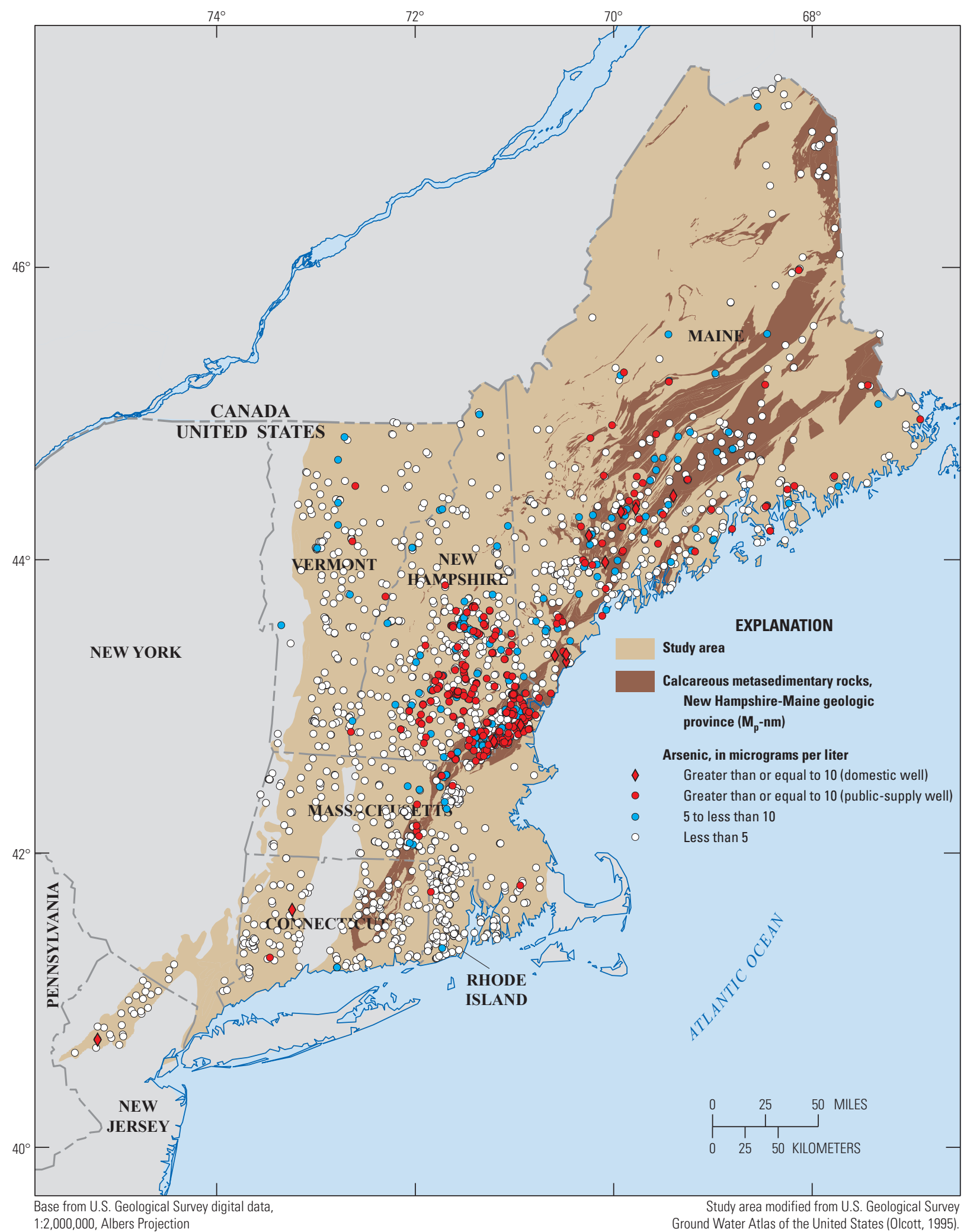

Figure 22. Spatial distributions of arsenic concentrations in water samples collected from domestic and public-supply wells in New England crystalline rock aquifers, 1995-2007. The calcareous metasedimentary rocks, New Hampshire-Maine geologic province $\left(\mathrm{M}_{\mathrm{c}}-\mathrm{nm}\right)$ lithology group is described in detail in table 7 . 
The As exceedance rate (13.3 percent) for this study also is nearly identical to a recent (2003-2006) bladder cancer study in Maine, New Hampshire, and Vermont, where As concentrations equaled or exceeded the MCL in 13.6 percent of water samples collected from 1,321 domestic bedrock wells (Debra Silverman and Dalsu Baris, National Institutes of Health, National Cancer Institute, written commun., 2009) (table 12). The As exceedance rate (13.3 percent) for this study was nearly double the national rate of 7.6 percent reported for public-supply systems in the United States (Focazio and others, 2000) and the national rate of 6.8 percent for domestic wells sampled from all aquifers (in which the NAWQA samples from this study are included) for the NAWQA Program (DeSimone, 2009) (table 12).

Other studies of New England drinking water also have shown that wells completed in crystalline rock can contain high concentrations $(>10 \mu \mathrm{g} / \mathrm{L})$ of As, but at variable occurrence rates. For studies in New Hampshire, Peters and others (1999), Montgomery and others (2003), and Moore (2004) reported that As concentrations exceeded the MCL in domestic and public-supply bedrock wells at rates as low as 2 percent to rates as high as 21 percent (table 12). When studies are targeted for aquifers known to contain As-enriched groundwater, the occurrence rate above the MCL in water samples can be much higher than in larger-scale studies where samples are more randomly selected (Peters, 2008). Yang and others (2009) found that 31 percent of water samples from 790 domestic bedrock wells in the greater Augusta area (about five towns in south-central Maine) had As concentrations greater than the MCL and that the highest As concentrations were associated with Silurian pelite-sandstone and pelitelimestone bedrock units (table 12). Peters and Blum (2003) reported that 52 percent of water samples from 146 domestic wells in a fractured-silicate bedrock aquifer in central New Hampshire had As concentrations greater than the MCL and that the highest As concentrations were associated with pelitic metasedimentary rocks. Lipfert and others (2006) reported that 69 percent of water samples from 35 domestic bedrock wells in a small mid-coastal Maine watershed comprising of sulfidic schist with granitic to diorite intrusions had As concentrations greater than the MCL (table 12). As mentioned previously in the study design section, the first NECB well network consists of 28 domestic wells (fig. 1) in areas where the geologic units are dominated by calcareous metasedimentary rocks in the New Hampshire-Maine $\left(\mathrm{M}_{\mathrm{c}}-\mathrm{nm}\right)$ geologic province. As a result, 28.6 percent of the water samples in this NAWQA well network had As concentrations equal to or greater than the MCL, a rate significantly higher than the rates for the other three NAWQA well networks (fig. 23).

Arsenic concentrations in this study were not significantly different when the samples were evaluated on the basis of water use (domestic versus public supply), land use, or population density. At this regional scale, agricultural lands (where for some areas, As-based pesticides may have been used in the past) were not found to be a factor in the occurrence of elevated As concentrations in groundwater. Although
As residues in soils resulting from past use of arsenical pesticides is a potential anthropogenic source, Robinson and Ayotte (2006) concluded that in areas of former arsenical pesticide use, As contamination did not significantly affect the distribution of elevated As concentrations in NECR groundwater.

Arsenic concentrations in this study, however, were significantly different when the water samples were evaluated on the basis of well-construction categories. High As concentrations $(>10 \mu \mathrm{g} / \mathrm{L})$ occurred in nearly 20 percent of the water samples from deep wells (well depths $>300 \mathrm{ft}$ and casing lengths $>50 \mathrm{ft}$ ) compared to only 6 percent from shallow wells (well depths $\leq 300 \mathrm{ft}$ and casing lengths $\leq 50 \mathrm{ft}$ ) (fig. 24). This is not surprising, since deeper bedrock wells are more likely to tap into fractures yielding older, high $\mathrm{pH}$ groundwater than shallower wells - a condition that favors As mobility.

Arsenic concentrations also were significantly different when the water samples in this study were evaluated on the basis of the location of wells within a lithology group (fig. 25A). Arsenic concentrations in sampled wells from the $\mathrm{M}_{\mathrm{c}}-\mathrm{nm}, \mathrm{I}_{\mathrm{p}}$, and $\mathrm{M}_{\mathrm{p}}$ lithology groups were significantly higher and exceeded the MCL more often (12.5 to 22.8 percent) than in sampled wells from the six other studied lithology groups (fig. 25B).

Notably, both the $\mathrm{M}_{\mathrm{c}}-\mathrm{wg}$ and $\mathrm{M}_{\mathrm{c}}-\mathrm{nm}$ lithology groups comprise predominantly calcareous metasedimentary rocks; however, rocks in the Waits River-Gile Mountain (wg) geologic province have lesser amounts of As-enriched minerals than rocks in the New Hampshire-Maine (nm) geologic province. This is an example of how the different tectonostratigraphic settings of crystalline rock units of similar lithology can have differences in groundwater quality. Arsenic concentrations in sampled wells from the $\mathrm{I}_{\mathrm{p}}$ and $\mathrm{I}_{\mathrm{m}}$ granite lithology groups may be related to dissolution of As-bearing minerals associated with pegmatitic dikes in (or near) granite plutons (Peters and others, 1999; Ayotte and others, 2006; Peters, 2008).

Arsenic concentrations in water samples from the domestic wells correlated positively with $\mathrm{pH}$ values and inversely correlated with $\mathrm{DO}$ and $\mathrm{NO}_{3}$ concentrations (table 11). These correlations are illustrated in figure 26, which shows the relations in domestic wells between As concentrations, $\mathrm{pH}$, and $\mathrm{NO}_{3}$. The largest As concentrations were associated with water samples under high $\mathrm{pH}(>7.5)$, low dissolved oxygen or "anoxic" ( $<1 \mathrm{mg} / \mathrm{L}$ ) conditions (fig. 26A) and with negligible amounts of $\mathrm{NO}_{3}$ (fig. 26B). Arsenic concentrations in water samples from the public-supply wells also correlated positively with $\mathrm{pH}$ values and inversely with $\mathrm{NO}_{3}$ concentrations (appendix 7).

Water samples collected from public-supply wells for compliance monitoring associated with the SDWA Program are commonly analyzed for $\mathrm{NO}_{3}$. Since $\mathrm{DO}$ and $\mathrm{pH}$ are important factors in As mobility in groundwater, combinations of $\mathrm{pH}$ with concentrations of $\mathrm{NO}_{3}$ (used here as a substitution for DO) may be a useful indicator of the possible occurrence of greater than background concentrations of As in groundwater. High As concentrations ( $\geq 10 \mu \mathrm{g} / \mathrm{L}$ ) occurred in 


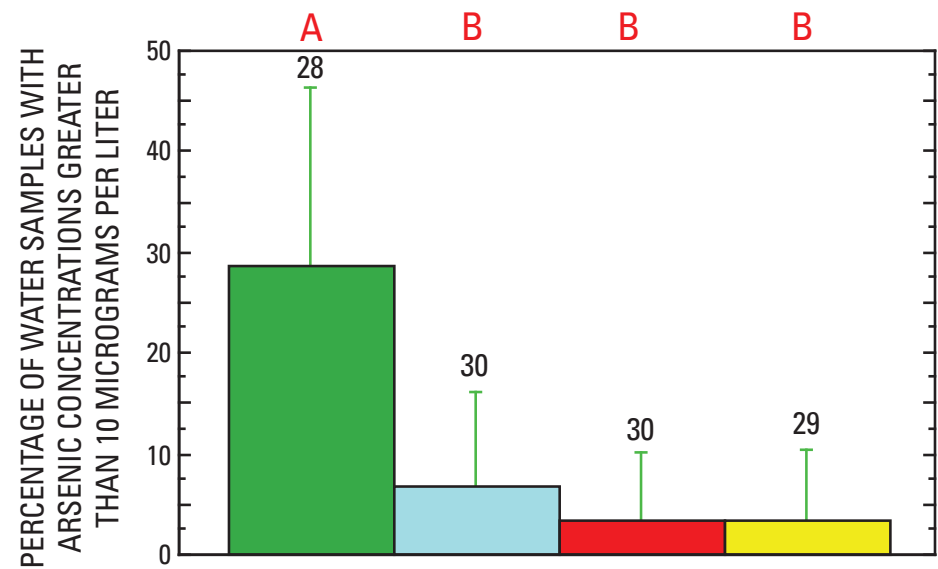

\section{EXPLANATION}

National Water-Quality Assessment program well network

New England Coastal Basins 1-predominantly

calcareous metasedimentary rocks

New England Coastal Basins 2-predominantly felsic igneous and pelitic rocks

Connecticut, Housatonic, and Thames Rivers Basinscrystalline rock, undifferentiated

Long Island-New Jersey Coastal Drainagescrystalline rock, undifferentiated

Statistical group from Tukey's test

A Groups with the same letter are not significantly different at an alpha value of 0.05

\section{Number of water samples}

Error bar representing the 95-percent confidence interval of the mean (binomial distribution)

Figure 23. Distribution of percentages of water samples with concentrations of arsenic greater than 10 micrograms per liter collected from domestic wells in New England crystalline rock aquifers, by the National Water-Quality Assessment Program well network, 1995-2000. Locations of well networks are shown in figure 1.

\section{EXPLANATION}

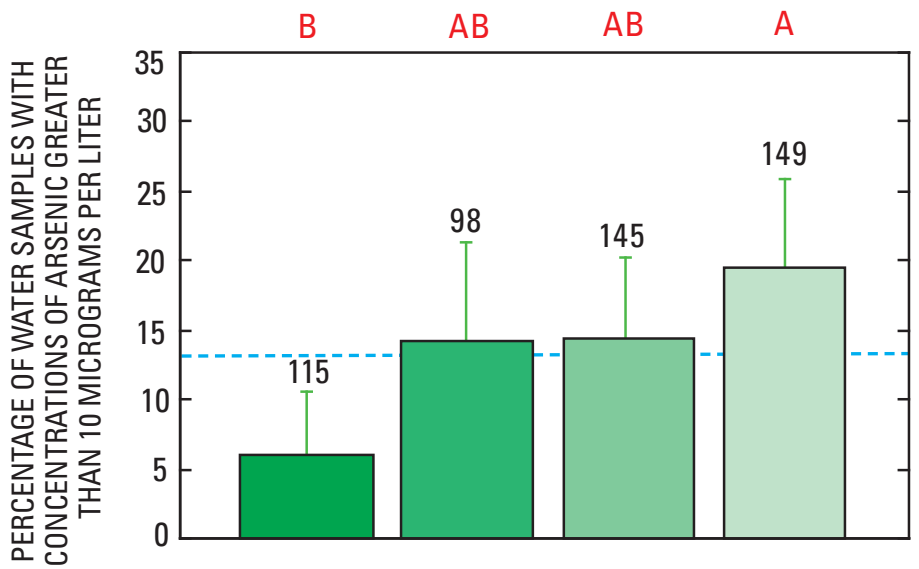

Shallow well, short casing length

Total depth of well is less than or equal to 300 feet and depth to the bottom of well casing is less than or equal to 50 feet

Shallow well, long casing length

Total depth of well is less than 300 feet and depth to the bottom of well casing is greater than 50 feet

Deep well, short casing length

Total depth of well is greater than 300 feet and depth to the bottom of well casing is less than or equal to 50 feet

Deep well, long casing length

Total depth of well is greater than 300 feet and depth to the bottom of well casing is greater than 50 feet

Statistical group from Tukey's test

A Groups with the same letter are not significantly different at an alpha value of 0.05

115 Number of water samples

Error bar representing the 95-percent confidence interval of the mean (binomial distribution)

Percentage of all wells in the study (13.3\%)

Figure 24. Distribution of percentages of water samples with concentrations of arsenic greater than 10 micrograms per liter collected from public-supply and domestic wells in New England crystalline rock aquifers, by categories of well depth and casing length, 1995-2007. See table 5 for the distribution of sampled wells on the basis of categories of well depth and casing length. 
A
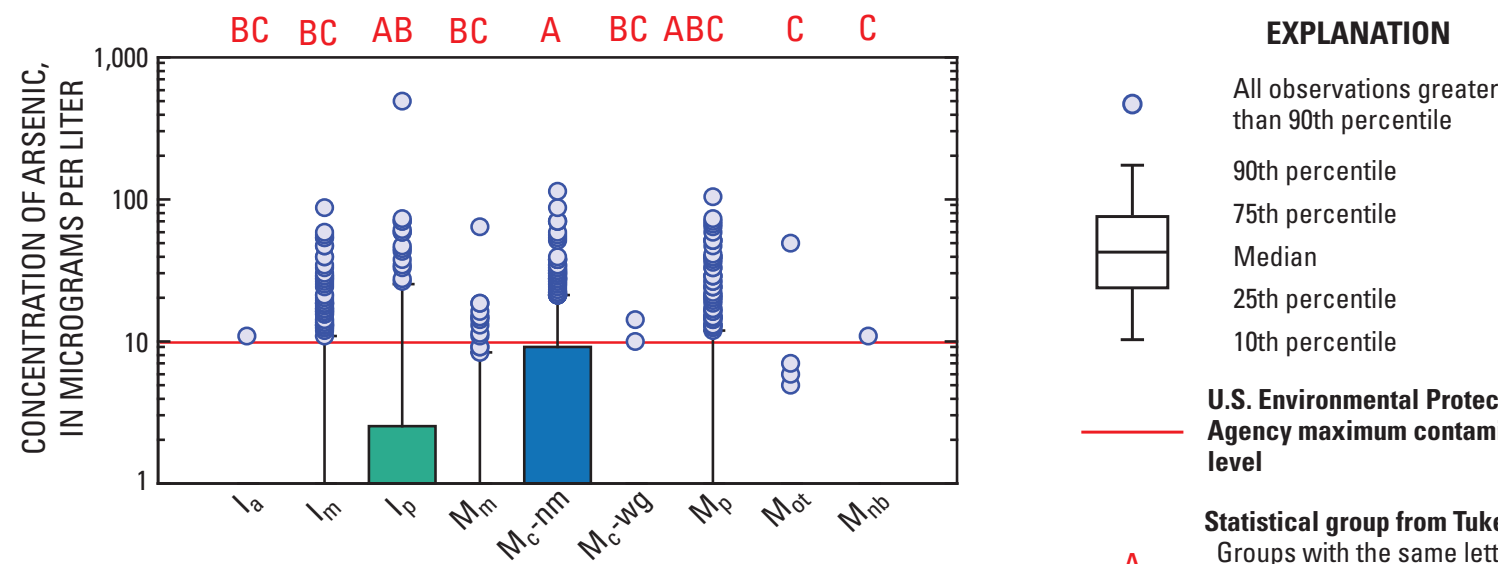

Lithology groups

Felsic igneous rocks

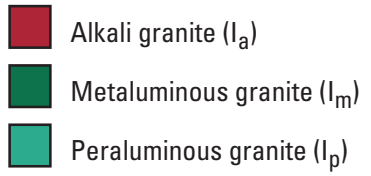

Mafic igneous and metamorphic rocks

Mafic $\left(\mathrm{M}_{\mathrm{m}}\right)$

\section{Metasedimentary rocks}

Calcareous, New Hampshire-Maine geologic province $\left(M_{C}-n m\right)$

Calcareous, Waits River-Gile

Mountain geologic province $\left(\mathrm{M}_{\mathrm{C}}-\mathrm{wg}\right)$

Pelitic $\left(M_{p}\right)$

Other $\left(\mathrm{M}_{\mathrm{ot}}\right)$

Narragansett Basin $\left(M_{n b}\right)$

B
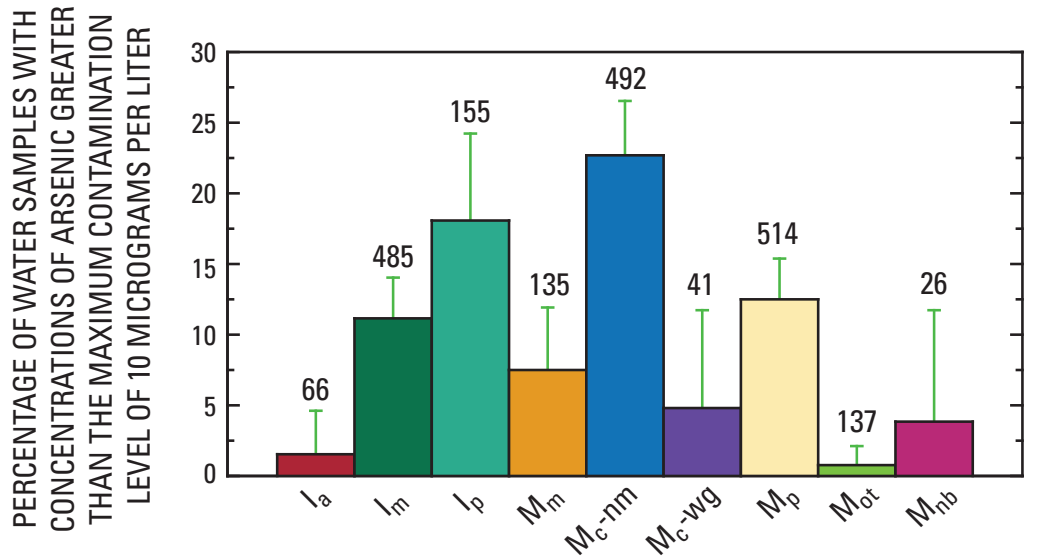

\section{EXPLANATION}

66

Number of samples

Error bar representing the

95-percent confidence

interval of the mean

(binomial distribution)

Figure 25. Distributions of $A$, concentrations of arsenic in water samples collected from public-supply and domestic wells in New England crystalline rock aquifers and B, percentages of these samples with concentrations of arsenic greater than the U.S. Environmental Protection Agency maximum contamination level of 10 micrograms per liter, by lithology group, 1995-2007. Water samples with concentrations of arsenic concentrations greater than 1,000 micrograms per liter are not shown in graph $A$. The lithology groups are described in detail in table 7 and illustrated in figure 5B. 
$\boldsymbol{A}$

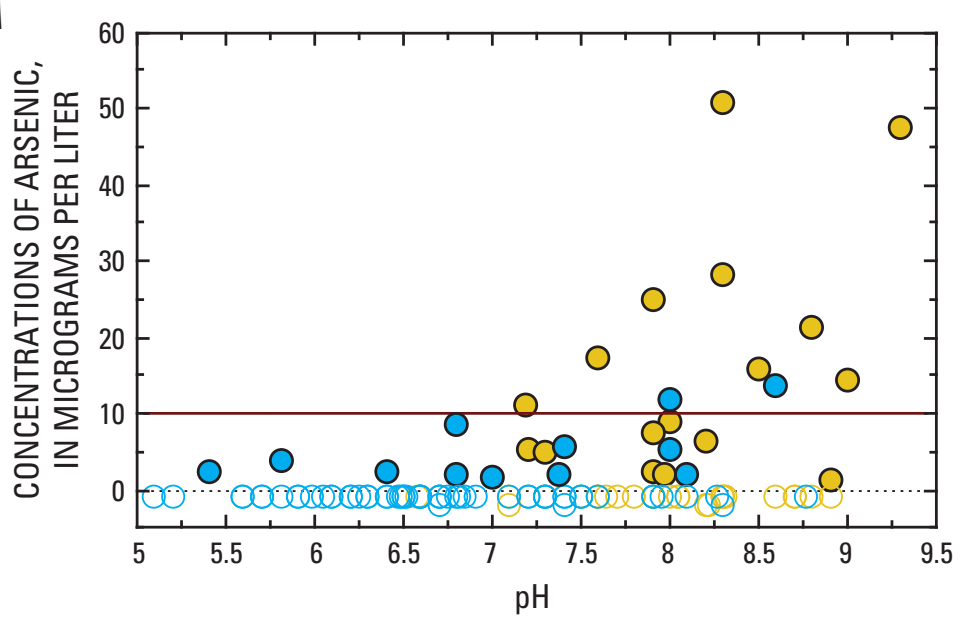

$\boldsymbol{B}$

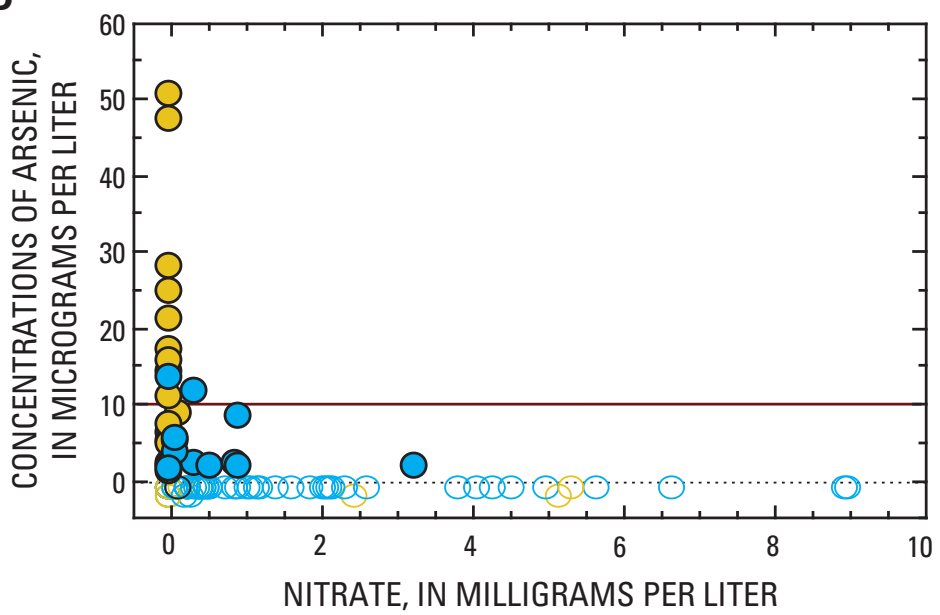

EXPLANATION

U.S. Environmental Protection Agency maximum contaminant level

Concentrations shown below this line are censored arsenic values

$0, \bigcirc$ Oxic condition-Dissolved oxygen equal to or greater than 1 milligram per liter.

$0, \bigcirc$ Anoxic condition-Dissolved oxygen less than 1 milligram per liter.

Figure 26. Relations of concentrations of arsenic in water samples collected from domestic wells in New England crystalline rock aquifers to $A, \mathrm{pH}$, and $B$, concentrations of nitrate, 1995-2000.

21 percent of 897 sampled wells with high $\mathrm{pH}(\geq 7)$ and low $\mathrm{NO}_{3}(<0.5 \mathrm{mg} / \mathrm{L}$; fig. 27). In contrast, high As concentrations occurred in less than 3 percent of 110 sampled wells with low $\mathrm{pH}(<7)$ and measureable $\mathrm{NO}_{3}(\geq 0.5 \mathrm{mg} / \mathrm{L})$ (fig. 27). Ayotte and others (2003) also noted that high As concentrations $(>10 \mu \mathrm{g} / \mathrm{L})$ occurred more frequently in groundwater with high $\mathrm{pH}(>7.5)$, even among wells in the same geologic setting.

Arsenic concentrations in the water samples also correlated positively with As concentrations in streambedsediment samples collected in New England for the NURE Program (appendix 7). Other studies found a similar relation between As in groundwater and nearby streambed sediments and concluded that rock-based As is the dominant source of the trace element in streambed sediments and groundwater in New England (Ayotte and others, 2006; Robinson and Ayotte, 2006). These correlations show the importance of both the geologic source of As and the geochemical processes that affect As mobility in groundwater. Sources of naturally occurring As in NECR aquifers include As-bearing sulfides, As sorbed onto iron-manganese hydroxide coating fractures, and other mineral surfaces. Sorbed As is mobilized from iron oxides by reductive dissolution in waters with low DO concentrations and (or) by desorption from the oxides in high pH waters (Welch and others, 2000; Ayotte and others, 2003; Lipfert and others, 2006; Peters, 2008).

Arsenic concentrations were much greater than the MCL in some of the water samples. Thirty-two samples (1.65 percent) collected from public-supply wells and 1 sample (1.14 percent) from a domestic well had As concentrations greater than five times $(50 \mu \mathrm{g} / \mathrm{L})$ the MCL. The greatest As concentration in this study $(2,400 \mu \mathrm{g} / \mathrm{L})$ was measured in a water sample from a public-supply well in Maine and completed in a pelitic rock member of the Silurian Sangerville Formation, a geologic unit that is mostly in the $M_{c}-n m$ lithology group (appendix 6). Rocks that are common 


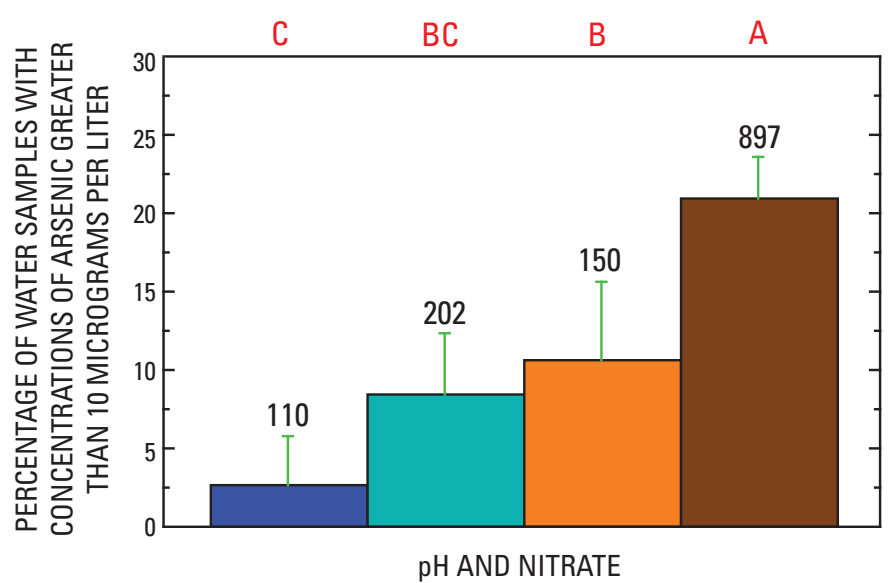

\author{
EXPLANATION \\ Water-quality criteria \\ Where $\mathrm{pH}<7$ and $\mathrm{NO}_{3}>0.5 \mathrm{mg} / \mathrm{L}$ \\ Where $\mathrm{pH} \geq 7$ and $\mathrm{NO}_{3} \geq 0.5 \mathrm{mg} / \mathrm{L}$ \\ Where $\mathrm{pH}<7$ and $\mathrm{NO}_{3} \leq 0.5 \mathrm{mg} / \mathrm{L}$ \\ Where $\mathrm{pH} \geq 7$ and $\mathrm{NO}_{3}<0.5 \mathrm{mg} / \mathrm{L}$ \\ Statistical group from Tukey's test \\ A Groups with the same letter are not \\ significantly different at an alpha \\ value of 0.05 \\ 110 Number of samples \\ Error bar representing the 95-percent confidence \\ interval of the mean (binomial distribution)
}

Figure 27. Distribution of percentages of water samples collected from public-supply and domestic wells in New England crystalline rock aquifers with concentrations of arsenic greater than the U.S. Environmental Protection Agency maximum contaminant level of 10 micrograms per liter, by categories of $\mathrm{pH}$ and nitrate concentrations, 1995-2007. ( $\leq$, less than or equal to; $\geq$, greater than or equal to; >, greater than; <, less than; mg/L, milligrams per liter; $\mathrm{NO}_{3}$, nitrate)

in the Sangerville Formation include crystallized calc-silicate rocks, granofels, and pelitic schist of high metamorphic grade (Osberg and others, 1985). In a different study in mid-coastal Maine, Lipfert and others (2006) reported that one well had groundwater with a mean As concentration of $1,990 \mu \mathrm{g} / \mathrm{L}$.

Nielsen and others (2010) conducted a recent assessment of all available As data from more than 11,000 domestic wells in Maine during 2005-09. The purpose of this study was to determine which Maine towns were at risk for very high concentrations of As in groundwater. Nielsen and others (2010) reported that four Maine towns (Surry, Danforth, Blue Hill, and Woolwich) had 1 percent or more of sampled domestic wells with As concentrations greater than $500 \mu \mathrm{g} / \mathrm{L}$. One domestic well in the town of Danforth, Maine, had a reported As concentration of 3,100 $\mu \mathrm{g} / \mathrm{L}$ (Nielsen and others, 2010).

\section{Radionuclides}

The occurrence and distribution of radionuclides in groundwater is controlled by the local geology and geochemistry of rock and water interactions. The most common radioactive elements, ${ }^{238}$ uranium and ${ }^{232}$ thorium, decay slowly and produce other radioactive elements, such as $\mathrm{Ra}$ and ${ }^{222} \mathrm{Rn}$, which in turn undergo radioactive decay and form their own daughter elements, with the end product being stable ${ }^{206} \mathrm{~Pb}$ (Ayotte and others, 2007). The factors relating to $U$ and ${ }^{222} \mathrm{Rn}$ measurements in water samples from the 117 NAWQA domestic wells in this study were analyzed in detail by Ayotte and others (2007), along with other wells sampled for the NAWQA program in the northern United States.

\section{Gross Alpha- and Gross Beta-Particle Activity}

Gross alpha-particle (gross alpha) activity is used mostly as an indicator of high levels of alpha-particle radioactivity without identifying the specific radionuclides responsible for the activity (DeSimone, 2009). In 893 water samples from domestic and public-supply wells, gross alpha activities were mostly in the range of $<3$ to $17.3 \mathrm{pCi} / \mathrm{L}$, with a median value of $<3 \mathrm{pCi} / \mathrm{L}$ (table 8 ). The spatial distribution of gross alpha activity in water samples from the domestic and public-supply wells is illustrated in figure 28. In this study, gross alpha activities were significantly higher in the domestic wells than in the public-supply wells. Gross alpha activities equaled or exceeded the MCL ( $15 \mathrm{pCi} / \mathrm{L})$ in 15.5 percent of 58 water samples from domestic wells and in 11.6 percent of 835 water samples from public-supply wells in New England (table 9). Gross alpha activities were significantly higher in the $I_{p}$ and $I_{a}$ granite lithology groups than all other studied groups. The five highest gross alpha activities in the water samples (ranging from 280 to $2,560 \mathrm{pCi} / \mathrm{L}$ ) were from four publicsupply wells in New Hampshire and one domestic well in Maine (appendix 6). Three of the five wells are completed in metasedimentary rocks.

Gross beta-particle (gross beta) activity is an indicator of beta-emitting isotopes in water, and analysis of gross beta is widely used in studies of naturally occurring radioactivity in groundwater (Welch and others, 1995). Gross beta activities in 58 water samples ranged from $<4$ to $653 \mathrm{pCi} / \mathrm{L}$, with a median value of $<4 \mathrm{pCi} / \mathrm{L}$ (appendix 1). Five samples (about 9 percent) had gross beta activities equal to or greater than the 


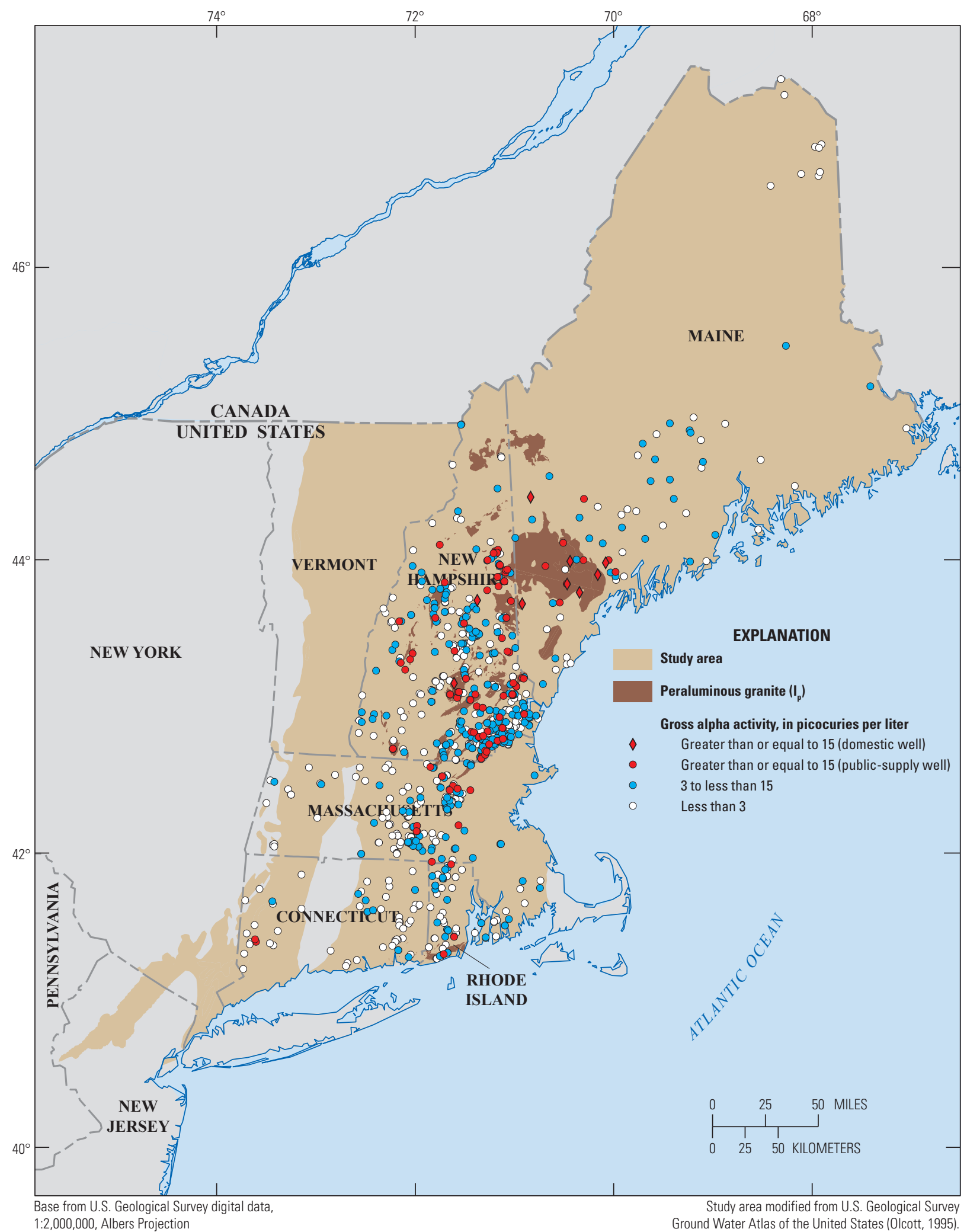

Figure 28. Spatial distribution of gross alpha-particle activities in water samples collected from domestic and publicsupply wells in New England crystalline rock aquifers, 1999-2007. The peraluminous granite $\left(I_{p}\right)$ is described in detail in table 7. 
screening level of $50 \mathrm{pCi} / \mathrm{L}$ (table 9). These five water samples (from domestic wells completed in $\mathrm{I}_{\mathrm{p}}$ and $\mathrm{M}_{\mathrm{p}}$ rocks) also had relatively high radon $(>5,700 \mathrm{pCi} / \mathrm{L})^{\mathrm{p}}, \mathrm{U}(>13.3 \mu \mathrm{g} / \mathrm{L})$, and gross alpha $(>34.5 \mathrm{pCi} / \mathrm{L})$ measurements. Only seven domestic wells (five of which were from this study) in all aquifers sampled nationally for the NAWQA Program had gross beta activities equal to or greater than the screening level (DeSimone, 2009).

\section{Radium}

Radium isotopes, which originate from the radioactive decay of uranium and thorium, occur as dissolved divalent cations in groundwater (Zapecza and Szabo, 1986). In water samples from 55 to 56 domestic wells, the maximum ${ }^{224} \mathrm{Ra}$ activity was $1.36 \mathrm{pCi} / \mathrm{L}$, the maximum ${ }^{226} \mathrm{Ra}$ activity was $6.75 \mathrm{pCi} / \mathrm{L}$, and the maximum ${ }^{228} \mathrm{Ra}$ activity was $2.1 \mathrm{pCi} / \mathrm{L}$ (appendix 1).

In water samples from 562 domestic and public-supply wells, combined radium $\left({ }^{226} \mathrm{Ra}\right.$ plus ${ }^{228} \mathrm{Ra}$ ) activities were mostly in the range of $<1$ to $2.7 \mathrm{pCi} / \mathrm{L}$; the maximum combined radium activity was $16 \mathrm{pCi} / \mathrm{L}$ (table 8 ). The spatial distribution of combined radium activities in water samples from these wells is illustrated in figure 29. Activities of combined radium were equal to or greater than the MCL of $5 \mathrm{pCi} / \mathrm{L}$ in 2 samples (about 4 percent) from the domestic wells and in 16 samples (about 3 percent) from the public-supply wells (table 9). The five highest combined radium activities ranged from 12.5 to $16 \mathrm{pCi} / \mathrm{L}$; four of these samples are from wells in metasedimentary rocks (appendix 6). Overall, however, combined radium activities did not differ significantly among the lithology groups. The combined radium activities in the public-supply well samples correlated strongly ( $p$-values $<0.0001)$ with activities of gross alpha $(\mathrm{rho}=0.37, \mathrm{n}=422)$ and radon ( $r h o=0.25, \mathrm{n}=265)$ and with concentrations of $\mathrm{U}$ in water (rho $=0.27, \mathrm{n}=309)$.

\section{${ }^{222}$ Radon}

Radon is a water-soluble, radioactive gas that originates from the decay of ${ }^{226} \mathrm{Ra}$, part of the ${ }^{238} \mathrm{U}$ decay series. Radon activities in water samples from the studied wells were highly variable. The radon activities in 943 water samples from all studied wells were mostly in the range of 540 to $11,400 \mathrm{pCi} / \mathrm{L}$, with a median radon activity of $2,600 \mathrm{pCi} / \mathrm{L}$ (table 8 ). The largest radon activity in a domestic well (in New Hampshire) was $215,200 \mathrm{pCi} / \mathrm{L}$ and the largest radon activity in a publicsupply well (also in New Hampshire) was 175,000 pCi/L. Both of these wells are completed in Concord Granite, a bedrock formation which is rich in two-mica granite plutons and is part of the $I_{p}$ lithology group (appendix 6). The spatial distribution of radon activities in water samples collected for the domestic and public-supply wells is illustrated in figure 30 .

Radon activities exceeded the proposed MCL $(300 \mathrm{pCi} / \mathrm{L})$ in 95 percent of the 943 water samples from the domestic and public-supply wells (table 9) and the proposed AMCL of
$4,000 \mathrm{pCi} / \mathrm{L}$ in 33 percent of these samples (table 9). Similarly high rates of radon occurrence in groundwater were reported for other crystalline rock aquifer systems in the Piedmont (south and central Appalachians) and in the Rocky Mountain Front Range (Colorado) areas of the Nation (Ayotte and others, 2007; DeSimone, 2009).

In this study, radon activities were not significantly different when the water samples were evaluated based on water use, land use, population density, or well-construction categories but they differed significantly when the evaluation was based on the geologic setting of the sampled wells. Radon activities were significantly higher in the $\mathrm{I}_{\mathrm{a}}, \mathrm{I}_{\mathrm{p}}$, and $\mathrm{M}_{\mathrm{nb}}$ lithology groups than in the other groups studied (fig. 31A). Although there are few water samples from the $M_{n b}$ lithology group, this finding is not surprising, considering that many of the conglomerate clasts in the Narragansett Basin consist of felsic volcanic and granitic rocks. Radon activities were equal to or greater than the proposed AMCL of $4,000 \mathrm{pCi} / \mathrm{L}$ in 79 percent of water samples from the $\mathrm{I}_{\mathrm{a}}$ lithology group, in 60 percent of water samples from the $\mathrm{I}_{\mathrm{p}}$ lithology group, and in 20 to 30 percent of water samples from all other groups having at least 9 samples (fig. 31B).

The radon activities in the sampled domestic wells correlated positively with $\mathrm{Pb}$ and $\mathrm{U}$ concentrations in water (table 11) and radon activities in the sampled public-supply wells correlated positively with gross-alpha activities, $\mathrm{U}$ concentrations (in water), and with U concentrations in NURE streambed sediments (appendix 8), indicating a geologic source for radon in NECR aquifers. The radon activities in the sampled public-supply wells correlated inversely with $\mathrm{pH}$, possibly suggesting that radon in NECR aquifers is associated with young groundwater, although, radon activities in 53 water samples from domestic wells were not significantly correlated with apparent residence time (appendix 4). Wood and others (2004) suggested that radon-enriched groundwater may move rapidly through fractured rock from its source $\left({ }^{226} \mathrm{Ra}\right)$ to pumped wells with little time available for radon decay. Enrichment of ${ }^{226} \mathrm{Ra}$ along the surfaces of water-bearing fractures in these rocks is a likely factor contributing to the elevated radon in fractured-rock aquifers (Wood and others, 2004).

\section{Uranium}

Uranium concentrations in 556 water samples collected from the public-supply and domestic wells were mostly in the range of $<1$ to $42 \mu \mathrm{g} / \mathrm{L}$, with a median concentration of $2.3 \mu \mathrm{g} / \mathrm{L}$ (table 8). The maximum $\mathrm{U}$ concentrations were $429 \mu \mathrm{g} / \mathrm{L}$ in samples from 117 domestic wells and 3,640 $\mu \mathrm{g} / \mathrm{L}$ in samples from 439 public-supply wells. Of the 556 studied wells, 14.2 percent had $U$ concentrations equal to or greater than the USEPA MCL of $30 \mu \mathrm{g} / \mathrm{L}$ (table 9). The spatial distribution of $U$ concentrations in water samples collected from the domestic and public-supply wells is illustrated in figure 32; many of the higher concentrations ( $\mathrm{U} \geq 30 \mu \mathrm{g} / \mathrm{L})$ occur in areas 


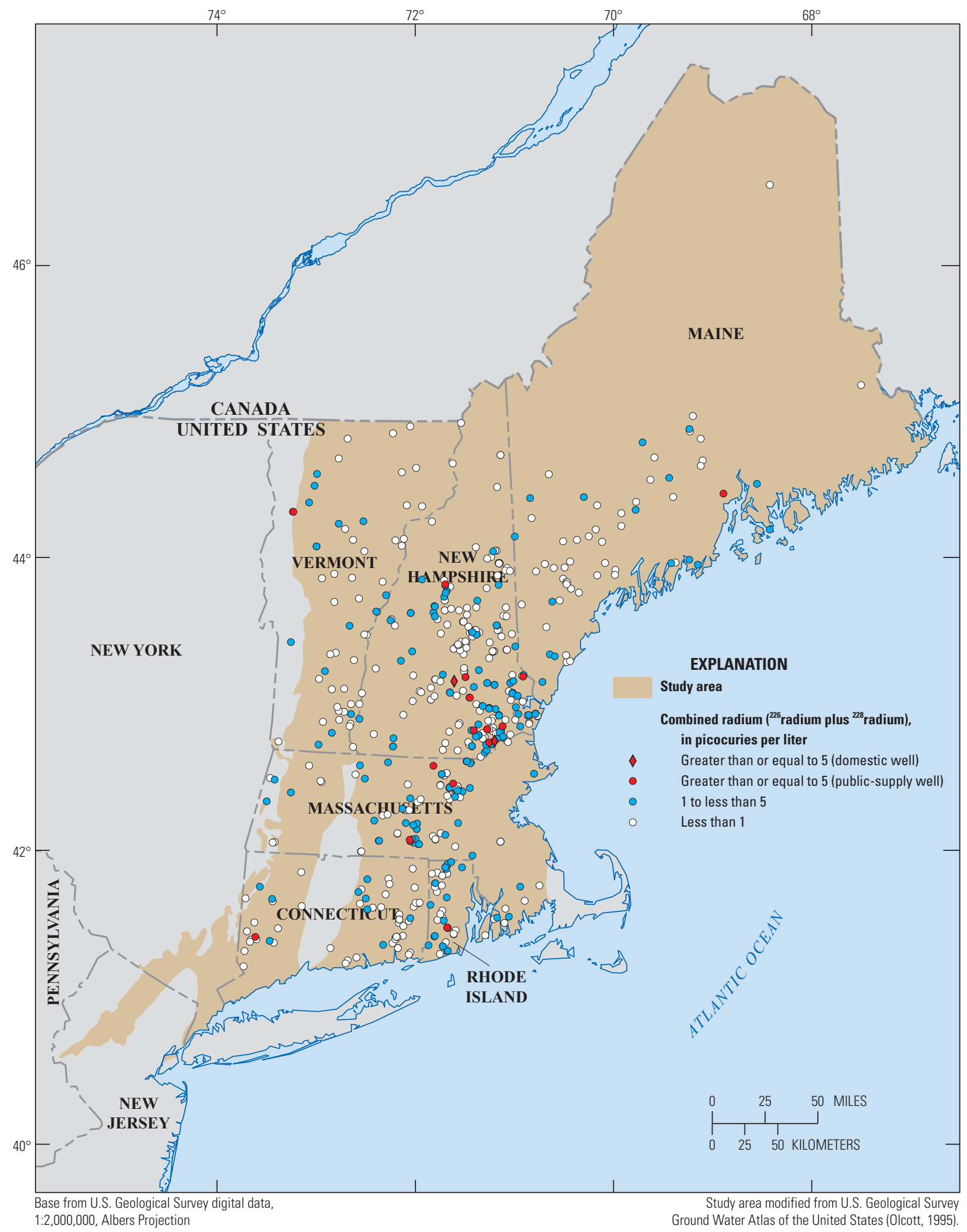

Figure 29. Spatial distribution of combined radium activities in water samples collected from domestic and public-supply wells in New England crystalline rock aquifers, 1999-2007. 


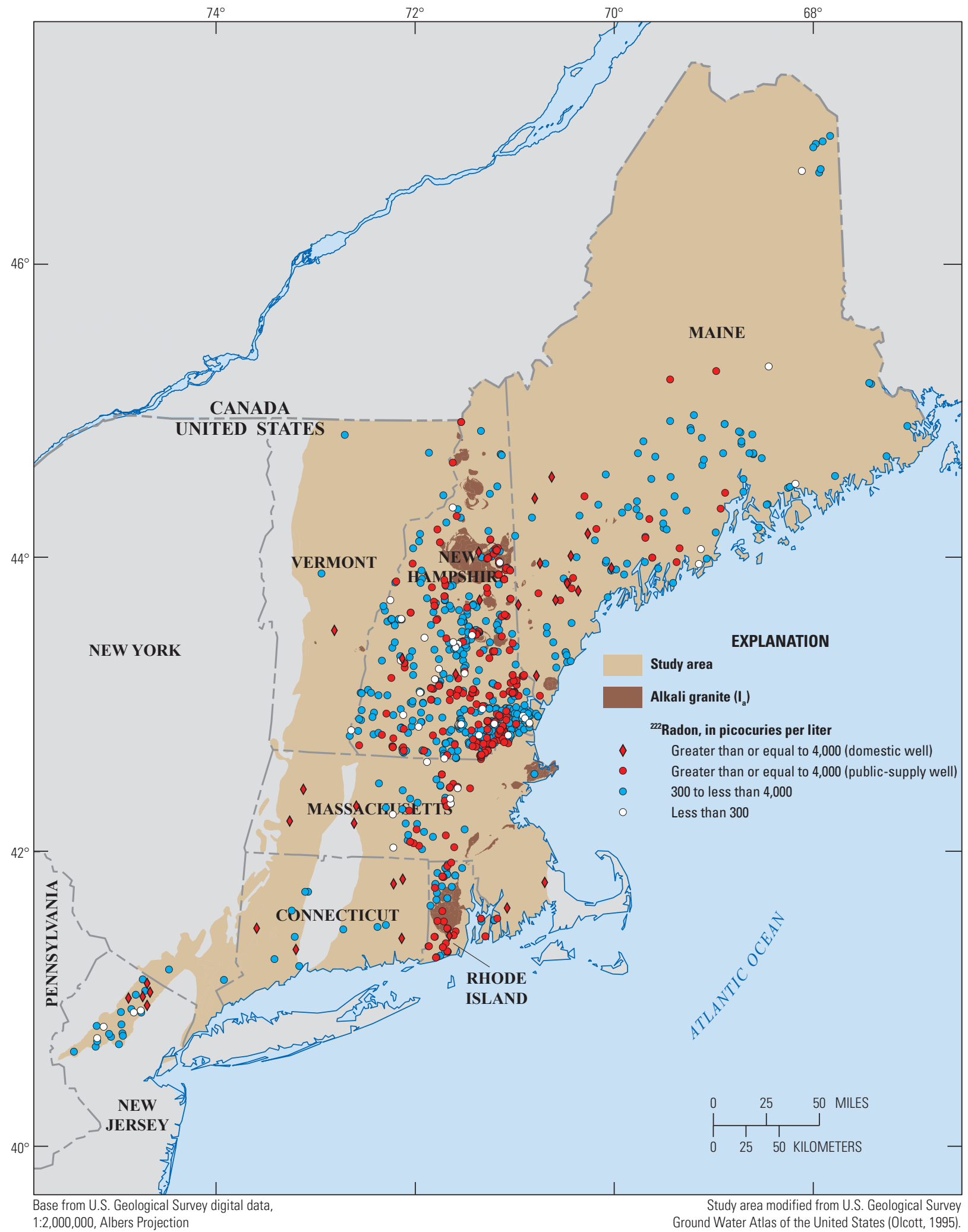

Figure 30. Spatial distribution of 222 radon activities in water samples collected from domestic and public-supply wells in New England crystalline rock aquifers, 1995-2007. The alkali granite $\left(I_{\mathrm{a}}\right)$ lithology group is described in detail in table 7. 
$\boldsymbol{A}$

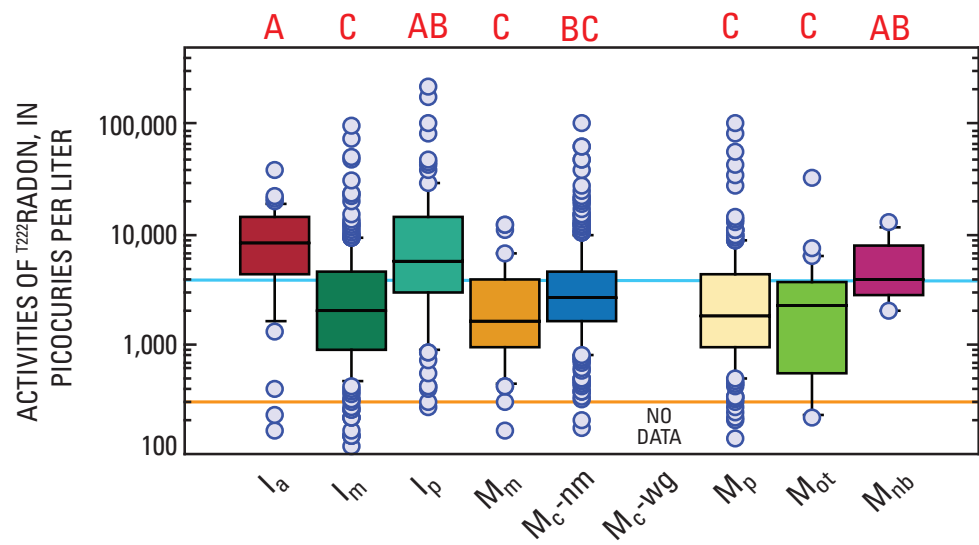

\section{EXPLANATION}

All observations greater than 90 th percentile

90th percentile

75th percentile

Median

25th percentile

10th percentile

All observations less

than 10th percentile

U.S. Environmental Protection Agency proposed alternative maximum contaminant level

Lithology groups

Felsic igneous rocks

Alkali granite $\left(\mathrm{I}_{\mathrm{a}}\right)$

Metaluminous granite $\left(\mathrm{I}_{\mathrm{m}}\right)$

Peraluminous granite $\left(I_{p}\right)$

Mafic igneous and metamorphic rocks

Mafic $\left(M_{m}\right)$
Metasedimentary rocks

Calcareous, New Hampshire-Maine geologic province $\left(\mathrm{M}_{\mathrm{c}}-\mathrm{nm}\right)$

Calcareous, Waits River-Gile Mountain geologic province $\left(\mathrm{M}_{\mathrm{c}}-\mathrm{wg}\right)$ Pelitic $\left(\mathrm{M}_{\mathrm{p}}\right)$

Other $\left(\mathrm{M}_{\mathrm{ot}}\right)$

Narragansett Basin $\left(M_{n b}\right)$
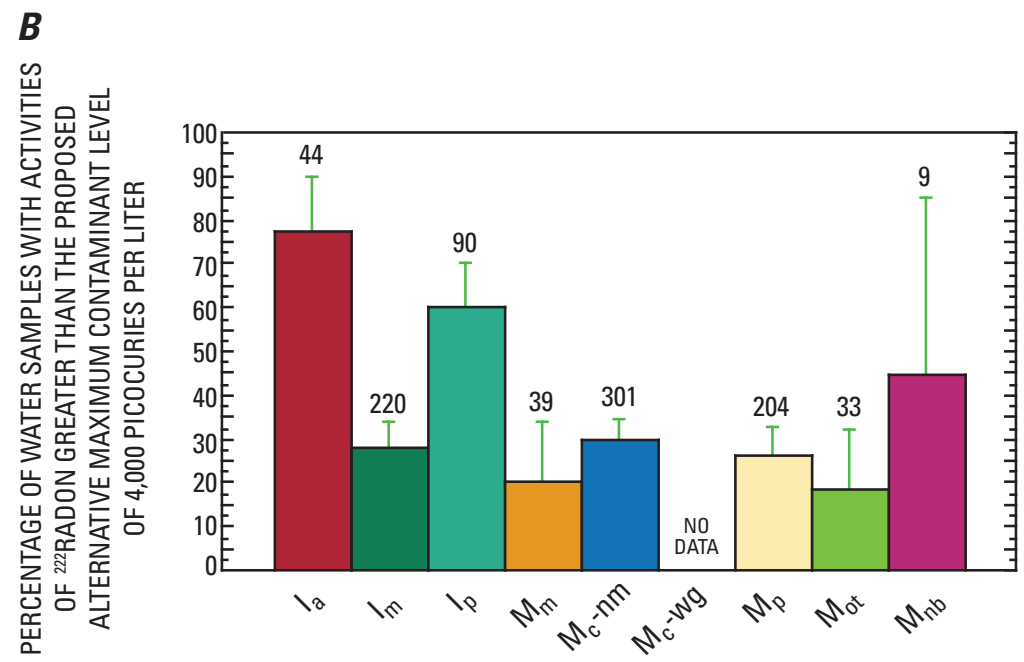

\section{EXPLANATION}

Number of samples

Error bar representing the 95-percent confidence interval of the mean (binomial distribution)

Figure 31. Distribution of $A$, activities of ${ }^{222}$ radon in water samples collected from public-supply and domestic wells in New England crystalline rock aquifers, and $B$, percentages of these samples with activities of ${ }^{222}$ radon greater than the proposed alternative U.S. Environmental Protection Agency maximum contaminant level of 4,000 picocuries per liter, by lithology group, 1995-2007. The lithology groups are described in detail in table 7 and illustrated in figure 5B. 


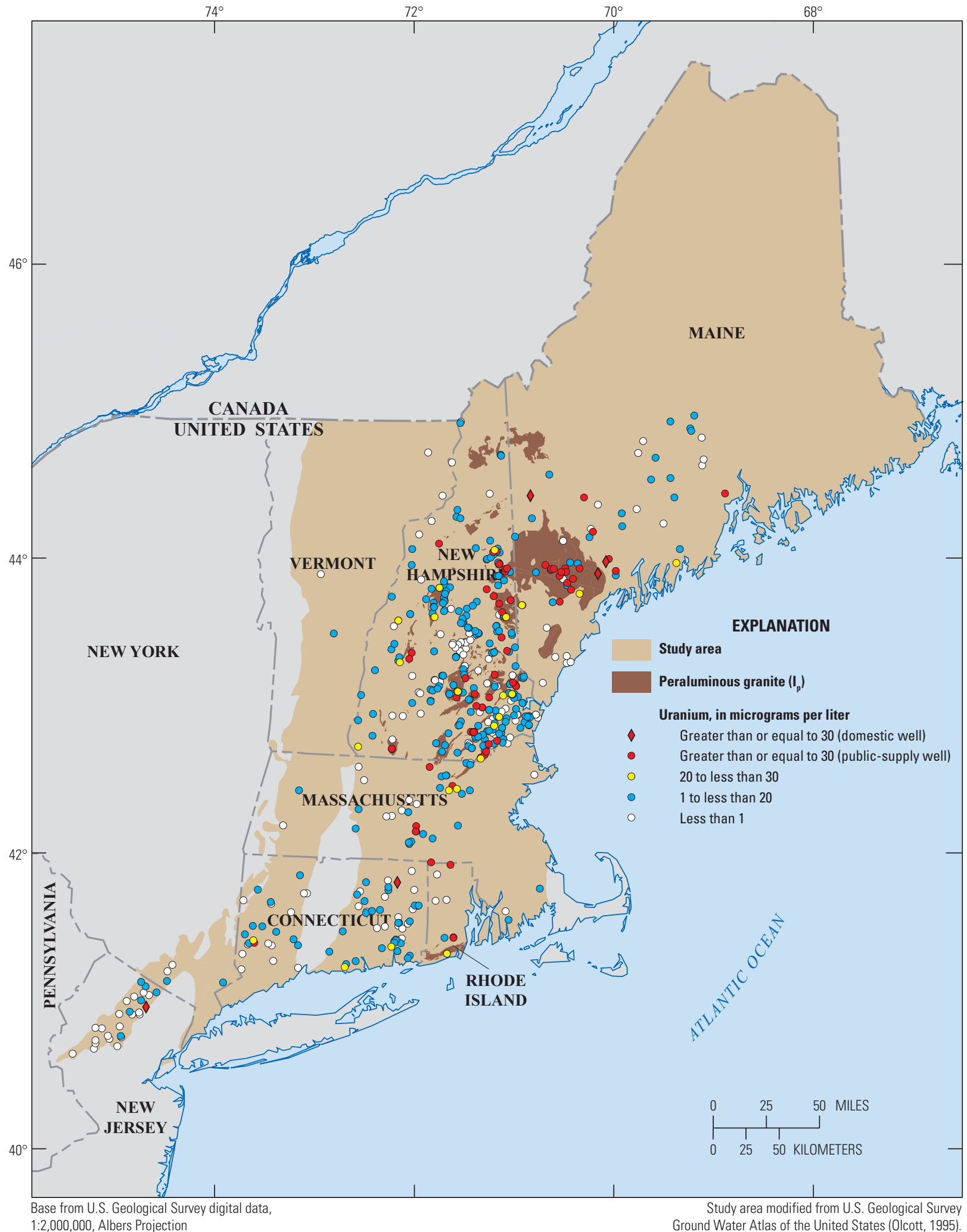

Figure 32. Spatial distribution of uranium concentrations in water samples collected from domestic and public-supply wells in New England crystalline rock aquifers, 1995-2007. The peraluminous granite $\left(I_{p}\right)$ lithology group is described in detail in table 7. 
classified as part of the peraluminous granite $\left(\mathrm{I}_{\mathrm{p}}\right)$ lithology group, although high concentrations occurred in most crystalline rock lithology groups.

Uranium concentrations were equal to or greater than the MCL in about 4.3 percent of 117 water samples from domestic wells (table 9). As reported previously, the 30 domestic wells from the second NECB well network (fig. 1) were selected from areas where the geologic units are dominated by felsic igneous rocks and pelitic rocks. However, only the U concentrations in water samples from the LINJ well network, where the bedrock consists predominantly of gneissic rocks $\left(\mathrm{M}_{\mathrm{ot}}\right.$ lithology group), are significantly lower than the $\mathrm{U}$ concentrations in water samples from wells in the other three NAWQA networks (fig. 33). DeSimone (2009) reports that 1.7 percent of water samples exceeded the MCL for $U$ from domestic wells sampled for the NAWQA Program in all aquifers nationally.

By comparison, 16.9 percent of $U$ concentrations in the 439 water samples from the public-supply wells equaled or exceeded the MCL (table 9). It is not known why the publicsupply well samples have U concentrations greater than the MCL at a rate that is nearly four times the rate for the domestic well samples. The water-quality data obtained from the SDWA Program are a reflection of available data from the individual state SDWA databases, whereas the water-quality data from the NAWQA Program were from randomly selected wells. Similar to conditions for $\mathrm{Fe}$ and $\mathrm{Mn}$, larger and more sustained pumping rates in the public-supply wells, in comparison to the domestic wells, might change geochemical conditions and (or) groundwater-flow patterns in ways that enhances the solubility and mobility of $U$ to pumped groundwater.

Uranium concentrations from all the wells studied were not significantly different when the samples were evaluated on the basis of land use, population density, or well-construction categories, but were significantly different when evaluated on the basis of the geologic setting of the sampled wells. Uranium concentrations were significantly higher in water samples from wells in the peraluminous granite $\left(\mathrm{I}_{\mathrm{p}}\right)$ lithology group than the other studied lithology groups (fig. 34A). Although $\mathrm{U}$ concentrations varied greatly in the water samples, $\mathrm{U}$ concentrations equal to or greater than the MCL occurred most frequently in samples from the $I_{p}\left(47.4\right.$ percent), $I_{a}$ (20 percent), and $\mathrm{M}_{\mathrm{c}}-\mathrm{nm}$ (12.7 percent) lithology groups (fig. 34B). None of the water samples from the $M_{m}$ lithology group had $\mathrm{U}$ concentrations equal to or greater than the MCL. Mafic rocks in the $\mathrm{M}_{\mathrm{m}}$ group generally have very low uranium content (Dostal and Capedri, 1978).

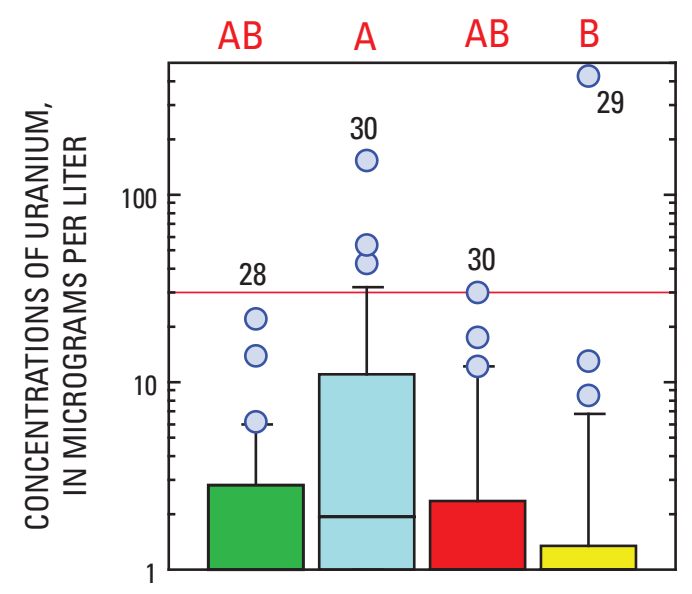

\section{EXPLANATION}

National Water-Quality Assessment Program well network

New England Coastal Basins 1-predominantly

calcareous metasedimentary rocks

New England Coastal Basins 2-predominantly

felsic igneous and pelitic rocks

Connecticut, Housatonic, and Thames Rivers Basinscrystalline rock, undifferentiated

Long Island-New Jersey Coastal Drainagescrystalline rock, undifferentiated

U.S. Environmental Protection Agency maximum contaminant level

All observations greater than 90th percentile
90th percentile
75th percentile
Median
25th percentile
10th percentile
A Statistical group from Tukey's test
Groups with the same letter are not significantly
different at an alpha value of 0.05

Figure 33. Distribution of concentrations of uranium in water samples collected from domestic wells in New England crystalline rock aquifers, by the National Water-Quality Assessment Program well network, 1995-2000. Locations of well networks are shown in figure 1. 
$\boldsymbol{A}$

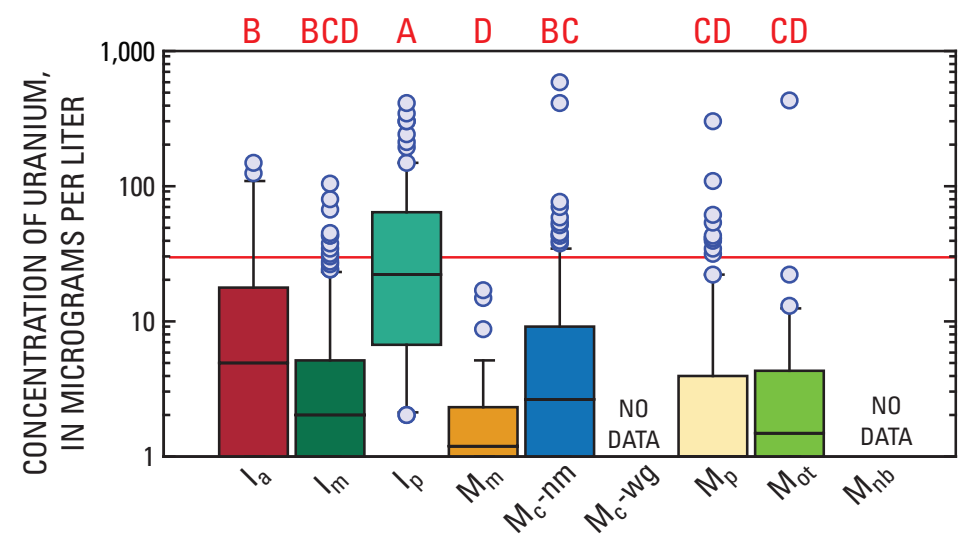

Lithology groups

Felsic igneous rocks

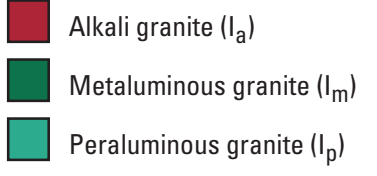

Mafic igneous and metamorphic rocks Mafic $\left(M_{m}\right)$
Metasedimentary rocks

Calcareous, New Hampshire-Maine geologic province $\left(M_{c}-n m\right)$

Calcareous, Waits River-Gile Mountain geologic province $\left(\mathrm{M}_{\mathrm{c}}-\mathrm{wg}\right)$

$\square$ Pelitic $\left(\mathrm{M}_{\mathrm{p}}\right)$

Other $\left(\mathrm{M}_{\mathrm{Ot}}\right)$

Narragansett Basin $\left(M_{n b}\right)$

\section{EXPLANATION}

O All observations greater than 90th percentile

90th percentile

75th percentile

Median

25th percentile

10th percentile

All observations less than 10th percentile

U.S. Environmental Protection Agency maximum contaminant level

Statistical group from Tukey's test

B Groups with the same letter are not significantly different at an alpha level of 0.05

\section{B}
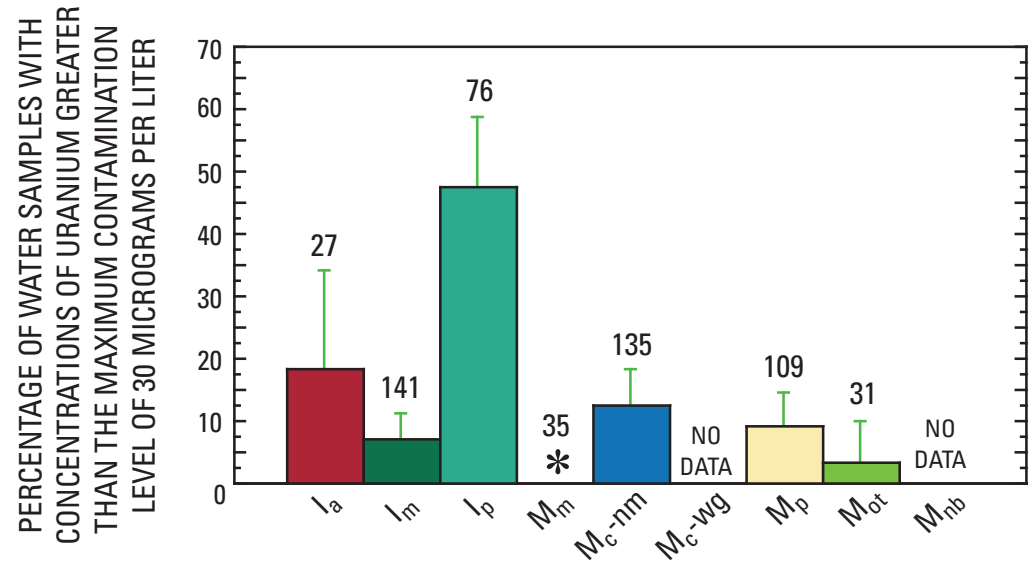

EXPLANATION

$27 \quad$ Number of samples

Error bar representing the

95-percent confidence

interval of the mean

(binomial distribution)

* Zero percent

Figure 34. Distribution of $A$, concentrations of uranium in water samples collected from public-supply and domestic wells in New England crystalline rock aquifers and $B$, percentages of these samples with concentrations of uranium greater than the U.S. Environmental Protection Agency maximum contaminant level of 30 micrograms per liter, by lithology group, 1995-2007. The lithology groups are described in detail in table 7 and illustrated in figure 5B. 
Water samples from one domestic well and 13 publicsupply wells ( 2.5 percent) had U concentrations five times $(>150 \mu \mathrm{g} / \mathrm{L})$ greater than the MCL. The five highest $\mathrm{U}$ concentrations in this study ranged from 420 to $3,640 \mu \mathrm{g} / \mathrm{L}$ (appendix 6). Three of these samples are from wells in metasedimentary rocks, which are not as enriched in $\mathrm{U}$ as in felsic igneous rocks, but which still can yield water with high U (appendix 6). Groundwater from wells with high $U$ concentrations may be affected by a hydrogeologic connection with adjacent or nearby aquifers containing groundwater enriched in $U$. These high $U$ concentrations also may be from wells that are completed in a different geologic setting than what is presented on the original, near-surface State geologic bedrock maps.

High U concentrations in groundwater from crystalline rock have been reported in previous investigations. Wathen (1986) reported that 18 percent of 111 water samples collected from drilled wells in two-mica granite (a felsic igneous rock that is part of the $I_{p}$ lithology group) in New Hampshire and Maine had U concentrations greater than $100 \mu \mathrm{g} / \mathrm{L}$; U concentrations in two of these wells exceeded $1,000 \mu \mathrm{g} / \mathrm{L}$. Uranium occurs above background concentrations in pelitic, felsic igneous, and volcanic rocks, and specifically in (1) accessory minerals such as zircon, sphene, and apatite; (2) inter-granular $\mathrm{U}$ distributed and sorbed along crystal boundaries, particularly biotite; and (3) secondary U minerals precipitated along fracture surfaces and grain boundaries (Hess and others, 1985).

In this study, $U$ concentrations in water samples from all 117 domestic wells correlated positively with $\mathrm{HCO}_{3}, \mathrm{Ca}, \mathrm{Mo}$, and As concentrations, and inversely with $\mathrm{Ba}$ and Fe concentrations (table 11). Ayotte and others (2007) found that the U concentrations in the 30 water samples from the second NECB well network (fig. 1) correlated positively with concentrations of $\mathrm{As}, \mathrm{DO}, \mathrm{Pb}$, and ${ }^{226} \mathrm{Ra}$, and with $\mathrm{U}$ concentrations in NURE streambed sediments; and correlated inversely with concentrations of Mn, Fe, Ba, and ${ }^{224} \mathrm{Ra}$. DeSimone (2009) found that the presence of $\mathrm{DO}$ and carbonate alkalinity were related to high $\mathrm{U}$ concentrations in domestic well samples from a variety of major aquifers studied nationally.

Uranium concentrations in water samples from the public-supply wells correlated positively with U concentrations in NURE streambed sediments (appendix 8), indicating a geologic source for $U$ in groundwater. Uranium concentrations in groundwater are controlled by factors including the amount of $U$ in the aquifer materials, the amount of DO, the oxidized state of the $\mathrm{U}$ ions, the availability of $\mathrm{CO}_{3}$ and $\mathrm{SO}_{4}$ to form complexes with $\mathrm{U}$, and the nature of the contact between U-bearing minerals and water (Hem, 1985; Hess and others, 1985; Wanty and others, 1990).

\section{Co-occurrence of Selected Radionuclides and Lead}

Uranium concentrations in the water samples correlated positively with $\mathrm{Pb}$ concentrations and with all other radionuclide constituents in this study (table 13). Lead concentrations in the domestic well samples correlated most strongly and positively with activities of gross alpha and radon. The many significant correlations among $\mathrm{U}, \mathrm{Pb}$, and the studied radionuclides indicate that the content of $\mathrm{U}$ and $\mathrm{Ra}$ in source rocks is probably the strongest factor relating to the occurrence of $U$ and other radionuclides in groundwater from NECR aquifers. Ayotte and others (2007) noted that $\mathrm{Pb}$ and radon were strongly correlated (Spearman's rho $=0.52, p$-value $<0.0001$, $\mathrm{n}=28$ ) in water samples from the second NECB well network (fig. 1) and hypothesized that a possible source for a small fraction of the total $\mathrm{Pb}$ may be radiogenic (stable) $\mathrm{Pb}$.

Because significant correlations were common among the studied radionuclides, the water samples were further examined to determine which of these radiochemical constituents most commonly co-occurred at concentrations or activities that were greater than existing or proposed human health benchmarks (table 14). A total of 344 water samples collected from domestic and public-supply wells provided water-quality data on U, gross alpha, and radon. Only one of the 344 water samples ( 0.3 percent) had a $U$ concentration equal to or greater than $30 \mu \mathrm{g} / \mathrm{L}$ when the associated gross alpha activity was less than $15 \mathrm{pCi} / \mathrm{L}$ and the radon activity was less than $4,000 \mathrm{pCi} / \mathrm{L}$. Similarly, gross alpha activities were equal to or greater than $15 \mathrm{pCi} / \mathrm{L}$ in only eight water samples (2.3 percent) when the associated $\mathrm{U}$ concentration was less than $30 \mu \mathrm{g} / \mathrm{L}$ and the radon activity was less than $4,000 \mathrm{pCi} / \mathrm{L}$. These data show that the presence of one radionuclide with a high activity or concentration generally indicates that other radionuclides would occur at high activities or concentrations. Uranium, which is measured in mass units using the ICP-MS method (Garborino and others, 2006), may be the easiest constituent to analyze when evaluating the overall radioactivity of groundwater from NECR aquifers. The $I_{a}$ and the $I_{p}$ lithology groups had the greatest percentages of water samples in which one or more of the three radionuclides exceeded existing or proposed human health benchmarks when compared to water samples in the other lithology groups (table 14).

\section{Organic Compounds}

The following sections discuss detections of pesticide and volatile organic compounds in groundwater from domestic wells completed in NECR aquifers and sampled for the NAWQA studies. Additional information was compiled for $\mathrm{M} t \mathrm{BE}$ in samples from public-supply wells collected for the SDWA Program (table 4); the information is discussed in the section "Volatile Organic Compounds."

\section{Pesticides}

Pesticides were rarely detected in water samples from 114 domestic wells in NECR aquifers from 1995 to 2000. The water samples were analyzed for 48 pesticide compounds, 44 of which were common to all samples (appendix 9). Thirtyone water samples from the domestic wells (27 percent) 
Table 13. Rho and probability values from Spearman correlations among selected radionuclides and lead in groundwater collected from domestic and public-supply wells in New England crystalline rock aquifers, 1995-2007.

[Spearman's coefficients (rho) are significantly correlated (in bold) when the $P$-values are less than or equal to 0.05 . A negative rho value indicates an inverse relation. Rho, Spearman's rho coefficient; $p$-value, Spearman's probability value; N, number of water samples; <, less than; --, $p$-value not calculated; Gross alpha, gross alpha-particle radioactivity; Gross beta, gross beta-particle radioactivity; Combined radium is ${ }^{226}$ radium plus ${ }^{228}$ radium]

\begin{tabular}{|c|c|c|c|c|c|c|c|}
\hline \multirow{2}{*}{$\begin{array}{c}\text { Correlation } \\
\text { variable }\end{array}$} & \multirow{2}{*}{$\begin{array}{c}\text { Spearman's } \\
\text { correlation } \\
\text { variables }\end{array}$} & \multicolumn{6}{|c|}{ Spearman's Rho coefficients, $\boldsymbol{P}$-values, and number of samples } \\
\hline & & Gross alpha & Gross beta & Uranium & ${ }^{222}$ Radon & $\begin{array}{l}\text { Combined } \\
\text { radium }\end{array}$ & Lead \\
\hline \multirow{2}{*}{ Gross alpha } & $p$-value & -- & $<0.0001$ & $<0.0001$ & $<0.0001$ & $<0.0001$ & 0.0014 \\
\hline & $\mathrm{N}$ & 893 & 57 & 457 & 615 & 477 & 57 \\
\hline \multirow{2}{*}{ Gross beta } & $p$-value & $<0.0001$ & -- & 0.0059 & 0.0034 & 0.0013 & 0.3821 \\
\hline & $\mathrm{N}$ & 57 & 58 & 58 & 57 & 56 & 58 \\
\hline \multirow[t]{2}{*}{ Uranium } & Rho & 0.776 & 0.358 & 1 & 0.553 & 0.224 & 0.257 \\
\hline & $p$-value & $<0.0001$ & 0.0059 & -- & $<0.0001$ & $<0.0001$ & 0.0163 \\
\hline${ }^{222}$ Radon & $\mathrm{N}$ & 615 & 57 & 417 & 943 & 319 & 82 \\
\hline \multirow[t]{3}{*}{ Combined radium } & Rho & 0.373 & 0.419 & 0.272 & 0.247 & 1 & 0.042 \\
\hline & $p$-value & $<0.0001$ & 0.0013 & $<0.0001$ & 0.00005 & -- & 0.7607 \\
\hline & $\mathrm{N}$ & 422 & 56 & 309 & 265 & 564 & 56 \\
\hline \multirow[t]{3}{*}{ Lead } & Rho & 0.414 & 0.117 & 0.257 & 0.378 & 0.042 & 1 \\
\hline & $p$-value & 0.0014 & 0.3821 & 0.0163 & 0.0005 & 0.7607 & -- \\
\hline & $\mathrm{N}$ & 57 & 58 & 87 & 82 & 56 & 87 \\
\hline
\end{tabular}

had one or more pesticides detected at estimated concentrations equal to or greater than $0.001 \mu \mathrm{g} / \mathrm{L}$, and seven of the domestic well samples ( 6 percent) had one or more pesticides detected at concentrations equal to or greater than $0.01 \mu \mathrm{g} / \mathrm{L}$. In comparison, Gilliom and others (2006) report that, nationally, 33 percent of all NAWQA sampled wells had one or more occurrence of pesticides. Of 48 pesticides, 6 herbicides (atrazine, EPTC, metolachlor, prometon, pronamide, and simazine), 2 pesticide degradates (deethylatrazine, p-p'-DDE), and 1 insecticide (dieldrin) were measureable at concentrations greater than $0.001 \mu \mathrm{g} / \mathrm{L}$ in at least 1 sample; four of these compounds (atrazine, deethylatrazine, metolachlor, and prometon) were measured at concentrations greater than $0.01 \mu \mathrm{g} / \mathrm{L}$ in at least one sample. Nearly all pesticide concentrations were considered estimated because they are less than or near LRLs, and no concentration exceeded human health benchmarks (appendix 9). The largest concentration of any pesticide measured was an estimated concentration of $0.06 \mu \mathrm{g} / \mathrm{L}$ for metolachlor, an herbicide that is relatively soluble in water, from a NJ-NY domestic well sample (appendix 9).

Gilliom and others (2006) reported that one or more pesticides exceeded a human health benchmark in about 1 percent of 2,356 domestic wells sampled nationally for the NAWQA Program. A national retrospective analysis of pesticides in groundwater sampled during 1991-95 for the NAWQA Program showed that groundwater in major aquifers has a substantially lower frequency of occurrence of pesticides than has shallow groundwater in agricultural and urban areas (U.S. Geological Survey, 1999). This difference occurred because, in general, wells from major aquifer studies are deeper, and a greater percentage of undeveloped land surrounds the sampled wells. For the domestic wells in this study, well depths generally exceed $200 \mathrm{ft}$ (table 6), and land use surrounding the wells was predominantly forested. 


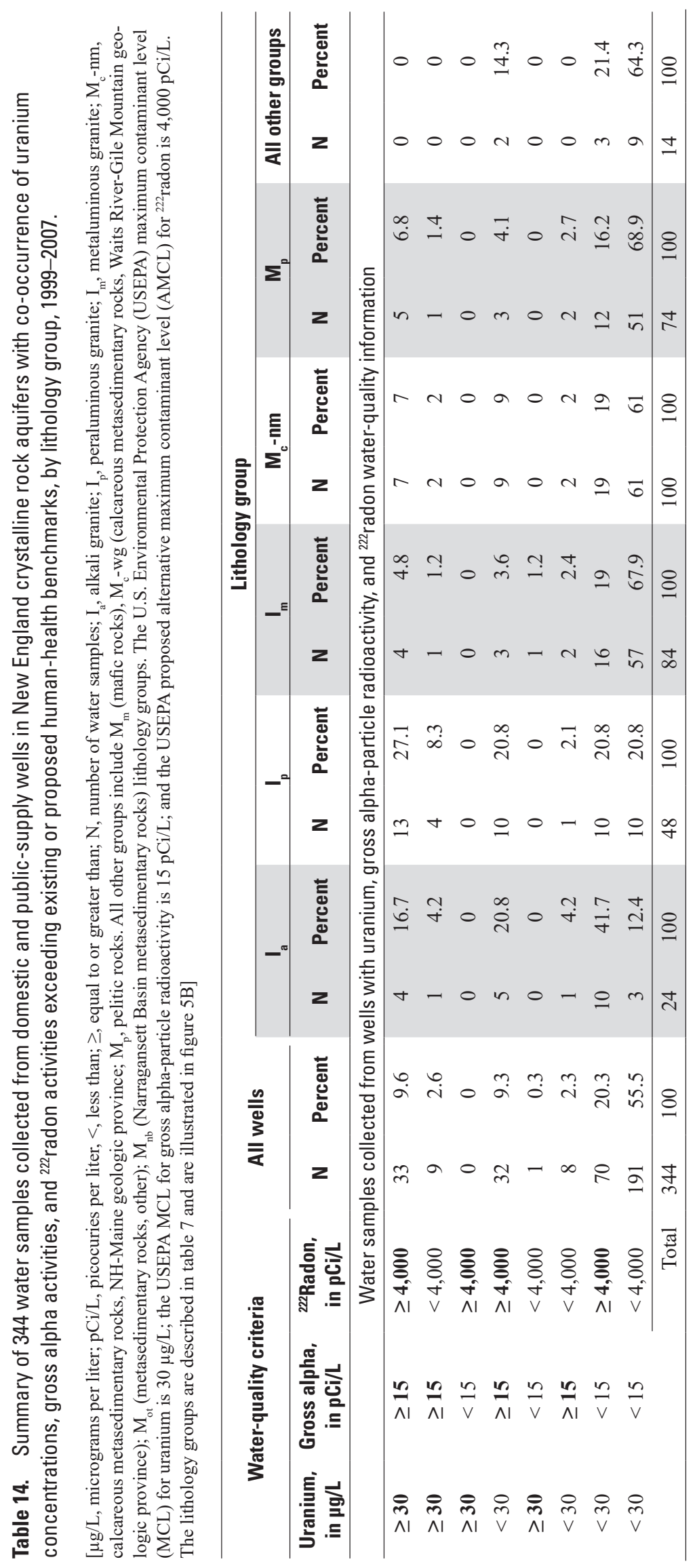


The greatest number of pesticide compounds detected in an individual water sample was three. The most common compounds detected in the water samples were atrazine and deethylatrazine. At the assessment level of $0.001 \mu \mathrm{g} / \mathrm{L}$, deethylatrazine, a degradate of atrazine (18 percent frequency detection), and atrazine ( 8 percent frequency detection) were the only pesticide compounds detected in more than 3 percent of the water samples collected from the domestic wells (appendix 9). Gilliom and others (2006) found that the most frequently occurring pesticide compounds in groundwater nationally were those that are highly persistent in the environment, are highly soluble in water, and had high levels of use in both agricultural and developed areas. Other studies found that detection frequencies of individual pesticides were also related to the tendency to adsorb onto aquifer materials and to the time needed for degradation (Kolpin and others, 1998; Barbash and others, 1999, 2001). Although the number and concentrations of pesticides in the domestic well samples were small, it is unclear whether similar results would be found for public-supply wells completed in crystalline rock, where pesticides are not analyzed at LRLs as low as for the NAWQA Program.

\section{Volatile Organic Compounds}

Of the 27 VOCs detected in water samples from 115 domestic wells at concentrations equal to or greater than $0.02 \mu \mathrm{g} / \mathrm{L}, 11$ were fuel hydrocarbons or oxygenates, 9 were solvents, 3 were trihalomethanes (THMs), 2 were refrigerants, and 2 were organic synthesis compounds (appendix 10). $\mathrm{M} t \mathrm{BE}$, a fuel oxygenate, was the most frequently occurring VOC ( 36 percent) at concentrations $\geq 0.02 \mu \mathrm{g} / \mathrm{L}$ in the domestic well samples (appendix 10; fig. 35). Although groundwater from these domestic wells is not chlorinated before use, chloroform (or trichloromethane) was detected $(\geq 0.02 \mu \mathrm{g} / \mathrm{L})$ in 33 percent of the domestic well samples (appendix 10; fig. 35). Ten other VOCs were detected $(\geq 0.02 \mu \mathrm{g} / \mathrm{L})$ in two or more water samples from the domestic wells: toluene (15 samples), carbon disulfide (10 samples), perchloroethene (7 samples), 1,1,1-trichloroethane (6 samples), 1,1-dichloroethane (5 samples), dichlorodifluoromethane (5 samples), tert-amyl methyl ether ( 3 samples), trichloroethene (2 samples), benzene (2 samples), and diisopropyl ether (2 samples) (appendix 10). Toluene, a fuel hydrocarbon, was detected $(\geq 0.02 \mu \mathrm{g} / \mathrm{L})$ in 42 percent of the blank samples (table 3 ) at concentrations similar to those reported for the environmental samples. This may have resulted in a higher toluene occurrence rate in the environmental samples than was actually present. Similar findings were reported when toluene was analyzed from blank and environmental samples collected from 1996 to 2008 from all available NAWQA groundwater and surface-water sampling sites (Bender and others (2011).

Seven of the nine VOCs shown in figure 35 occurred more frequently (at concentrations $\geq 0.02 \mu \mathrm{g} / \mathrm{L}$ ) in water samples from the domestic wells in this study than in domestic wells (DeSimone, 2009) or all wells in major aquifers
(Carter and others, 2008) studied nationally for the NAWQA Program. NECR aquifers can be highly vulnerable to VOC contamination because of their low capacity for storing groundwater and their potentially high Darcian (linear) flow velocities in open fractures.

Forty-three water samples from 86 domestic wells (50 percent) in NECR aquifers contained two or more detectable VOCs $(\geq 0.02)$. The most common mixture of VOCs in the NAWQA domestic wells with two or more detectable concentrations consisted of $\mathrm{M} t \mathrm{BE}$ and chloroform. Three of the four water samples with measureable chloroform $(\geq 0.2 \mu \mathrm{g} / \mathrm{L})$ from the domestic wells in the CONN study also contained measurable $\mathrm{M} t \mathrm{BE}(\geq 0.2 \mu \mathrm{g} / \mathrm{L})$. Twelve of the 25 water samples from the LINJ and NECB studies with measureable chloroform $(>0.02 \mu \mathrm{g} / \mathrm{L})$ also had measureable $\operatorname{M} t \operatorname{BE}(\geq 0.02 \mu \mathrm{g} / \mathrm{L})$.

Two wells had 10 VOCs each $(\geq 0.02 \mu \mathrm{g} / \mathrm{L})$ in the same sample. One of the domestic wells sampled by the NECB study contained low total concentrations $(0.79 \mu \mathrm{g} / \mathrm{L}$ summed $)$ of chloroform, 1,2,3-trimethylbenzene, 1,2,4-trimethylbenzene, 1,3,5,trimethylbenzene, ethyl-toluene, isopropylbenzene, n-propylbenzene, xylene, carbon disulfide, and toluene. The other domestic well, sampled by the LINJ study, contained variable concentrations ( $31.6 \mu \mathrm{g} / \mathrm{L}$ summed) of chloroform, dichlorodifluoromethane, trichlorofluoromethane, $\mathrm{M} t \mathrm{BE}$, methyl tert-pentyl ether, tetrachloroethylene, trichloroethylene, 1,1-dichloroethane, 1,1,1-trichloroethane, and diisopropyl ether. MtBE accounted for 96 percent of the summed VOC concentration in this water sample.

\section{Chloroform}

The maximum chloroform concentration was $2.82 \mu \mathrm{g} / \mathrm{L}$ in water samples from 115 domestic wells sampled for the NAWQA Program, substantially lower than the MCL $(80 \mu \mathrm{g} / \mathrm{L})$ that the USEPA has established for total trihalomethanes (TTHMs) (appendix 10). The spatial distribution of chloroform concentration in water samples collected from the domestic wells is illustrated in figure 36. The highest chloroform concentrations ( $>1 \mu \mathrm{g} / \mathrm{L}$ ) were associated with the NJ-NY domestic wells (fig. 36).

Chloroform concentrations in samples from domestic wells correlated positively with concentrations of $\mathrm{NO}_{3}$, $\mathrm{M} t \mathrm{BE}, \mathrm{Cl}$, and $\mathrm{DO}$, and with percent developed lands and population density (appendix 11) —water-quality constituents and ancillary variables known to be associated with human activities (Ivahnenko and Barbash, 2004; Carter and others, 2008). Chloroform concentrations correlated inversely with well depth and $\mathrm{pH}$ (appendix 11). Depths of the NJ-NY domestic wells were relatively shallower (median well depth $=$ $202 \mathrm{ft}$ ) than the domestic wells in New England (median well depth $=263 \mathrm{ft}$ ). The shallower well depths, lower $\mathrm{pH}$ values, and higher DO concentrations associated with the NJ-NY domestic well samples are indicative of relatively shallow and younger groundwater that may be more vulnerable to human activities in comparison to the generally deeper and 


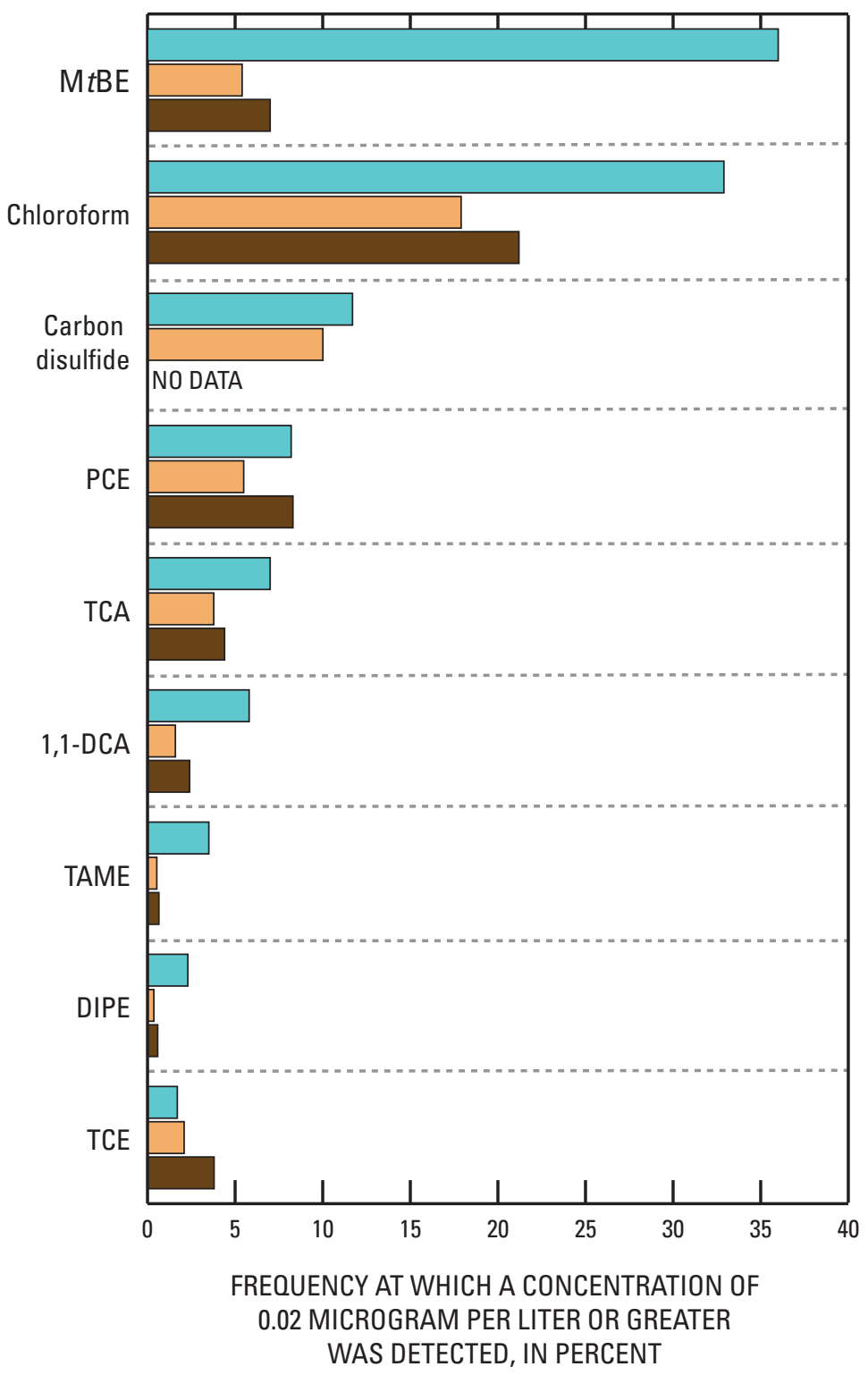

\section{EXPLANATION}

Domestic wells in New England crystalline rock aquifers, 1995-2000

Domestic wells in all major aquifers nationally, 1991-2004 (from DeSimone, 2009; appendix 7-1)

All wells in 98 major aquifers nationally, 1985-2002 (from Carter and others, 2008; table 1)

Figure 35. Detection frequencies for the nine most common volatile organic compounds in water samples collected from domestic wells in New England crystalline rock aquifers, 1995-2000. (MtBE, methyl-tert-butyl ether; TCA, 1,1,1-trichloroethane; PCE, perchloroethene; 1,1-DCA, 1,1-dichloroethane; TCE, trichloroethene; DIPE, diisopropyl ether; TAME, tert-amyl methyl ether) 


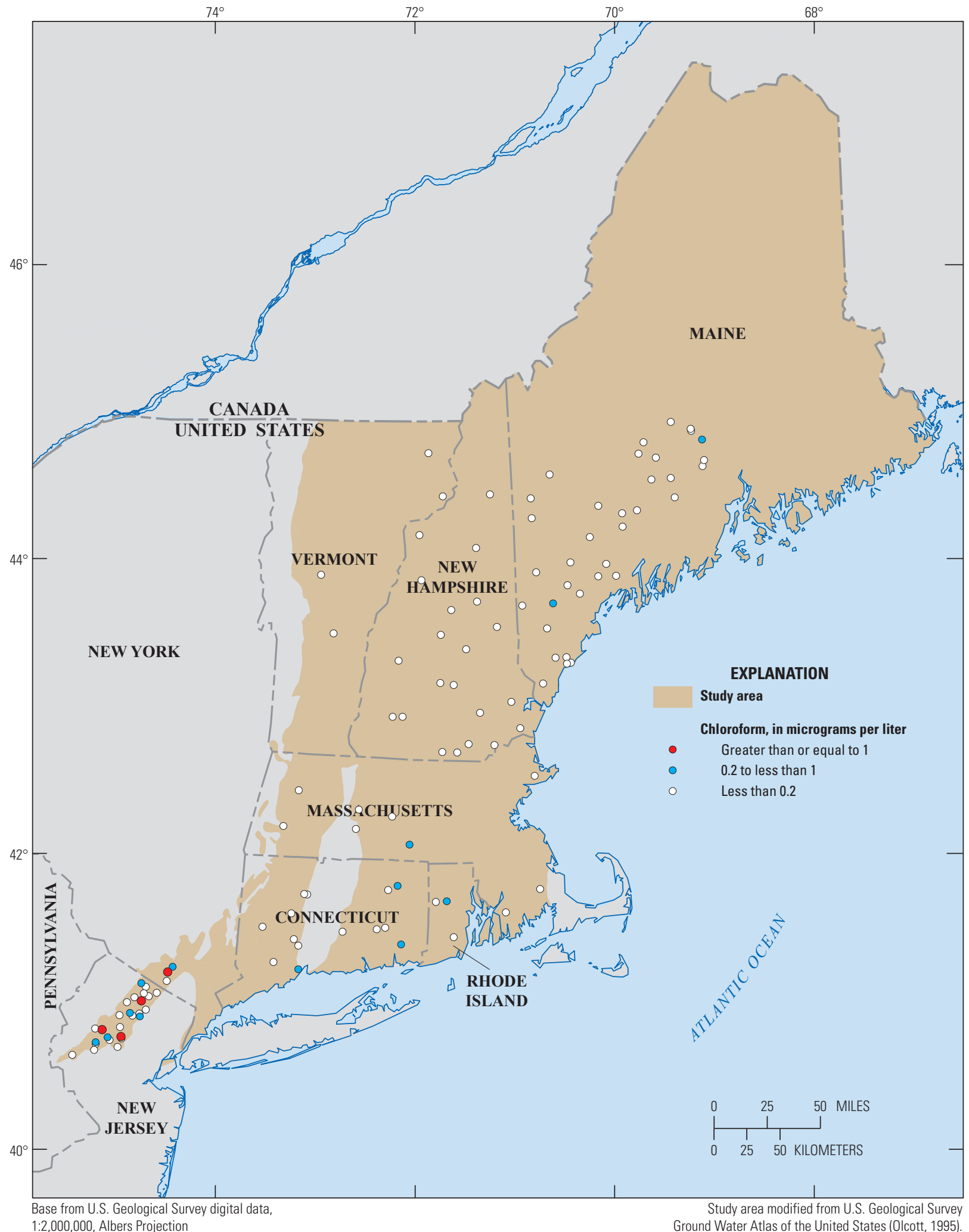

Figure 36. Spatial distribution of chloroform concentrations in water samples collected from domestic wells in New England crystalline rock aquifers, 1995-2000. 
older groundwater associated with the domestic wells in New England. These factors may explain the occurrence rate of chloroform $(\geq 0.2 \mu \mathrm{g} / \mathrm{L})$ that is higher in the NJ-NY domestic well samples (34 percent) than in the domestic wells from New England (8.1 percent). Potential sources of chloroform and other THMs to both public and domestic wells include the use of municipally supplied chlorinated water to irrigate lawns, golf courses, gardens, and other areas; the use of septic systems; the regulated discharge of chlorinated wastewater to surface waters; and leakage of chlorinated water from distribution systems for drinking water or wastewater sewers (Ivahnenko and Zorgorski, 2006).

\section{Methyl tert-Butyl Ether}

$\mathrm{M} t \mathrm{BE}$ concentration in water samples from 1,299 domestic and public-supply wells were mostly in the range of $<1$ to $1 \mu \mathrm{g} / \mathrm{L}$ (table 8). The maximum $\mathrm{M} t \mathrm{BE}$ concentration in 115 domestic well samples was $30.2 \mu \mathrm{g} / \mathrm{L}$ (appendix 10) and the maximum $\mathrm{M} t \mathrm{BE}$ concentration in 1,184 publicsupply well samples was $190 \mu \mathrm{g} / \mathrm{L}$ (appendix 3). The spatial distribution of $\mathrm{M} t \mathrm{BE}$ concentrations in water samples from the domestic and public-supply wells is illustrated in figure 37 . $\mathrm{M} t \mathrm{BE}$ concentrations were $\geq 1 \mu \mathrm{g} / \mathrm{L}$ in 11.3 percent of the domestic well samples and in nearly 10 percent of the publicsupply well samples. Currently (2011), there are no national enforceable drinking-water standards for $\mathrm{M} t \mathrm{BE}$, although the USEPA has established an advisory level of 20 to $40 \mu \mathrm{g} / \mathrm{L}$ for taste and odor (U.S. Environmental Protection Agency, 1997). The State of New Hampshire Department of Environmental Services (NHDES) has established a maximum contaminant level of $13 \mu \mathrm{g} / \mathrm{L}$ for community water systems in New Hampshire (New Hampshire Department of Environmental Services, 2009). Groundwater from 6 of 1,299 studied wells ( 0.46 percent) equaled or exceeded the USEPA advisory levels (table 9), and groundwater from 9 of the studied wells (0.7 percent) equaled or exceeded the NHDES MCL of $13 \mu \mathrm{g} / \mathrm{L}$.

On a regional scale, the frequency of $\mathrm{M} t \mathrm{BE}$ concentrations $\geq 1 \mu \mathrm{g} / \mathrm{L}$ in water samples from all wells was significantly different when compared to categories of population density and land use (fig. 38). Water samples from 13.6 percent of wells in areas of high population density $\left(\geq 50\right.$ persons $\left./ \mathrm{km}^{2}\right)$ had $\mathrm{M} t \mathrm{BE}$ concentrations $\geq 1 \mu \mathrm{g} / \mathrm{L} ; 4.7$ percent of wells in areas of low population density $\left(<50\right.$ persons $\left./ \mathrm{km}^{2}\right)$ had concentrations $\geq 1 \mu \mathrm{g} / \mathrm{L}$ (fig. 38A). Similar relations with population density were found in a statewide investigation of $\mathrm{M} t \mathrm{BE}$ in New Hampshire (Ayotte and others, 2008). Nationally, Moran and others (2005) found that population density was an important factor relating to the detection and concentrations of $\mathrm{M} t \mathrm{BE}$ in underlying groundwater. In this study, $\mathrm{M} t \mathrm{BE}$ concentrations $\geq 1 \mu \mathrm{g} / \mathrm{L}$ occurred in 16 percent of wells in predominantly developed land, 5 percent of wells in predominantly undeveloped land (fig. 38B), and in 4 percent in wells in predominantly agricultural lands.
$\mathrm{M} t \mathrm{BE}$ concentrations in water samples from the studied wells correlated positively with concentrations of specific conductance, $\mathrm{Cl}$, and chloroform; percentage of developed lands; and population density - factors that generally relate to human activities (appendix 11). MtBE concentrations in water samples from the domestic wells correlated inversely with apparent residence time (ages) and $\mathrm{pH}$ (appendix 11), indicating that younger groundwaters in NECR aquifers are more vulnerable to $\mathrm{M} t \mathrm{BE}$ contamination than are older groundwaters. $\mathrm{M} t \mathrm{BE}$ concentrations in samples from domestic wells relative to apparent ages, DO concentrations, field $\mathrm{pH}$, water levels, depth to bottom of well casing, and well depths are shown in figure 39 . Water samples with younger apparent ages ( $<25$ years) had more MtBE measurements $(>0.2 \mu \mathrm{g} / \mathrm{L})$ than did water samples with older apparent ages ( $\geq 25$ years; fig. 39A). MtBE was first introduced into gasoline in 1979, as lead was being phased out, and was in widespread use by 1992 in response to the USEPA mandate to increase the octane level of gasoline (New Hampshire Department of Environmental Services, 2009). Since MtBE was not in use prior to 1979, it is not surprising that $\mathrm{M} t \mathrm{BE}$ was not detected in the samples with older apparent ages. In contrast to $\mathrm{NO}_{3}, \mathrm{M} t \mathrm{BE}$ concentrations in the domestic wells were not significantly correlated with well depth (fig. 39F), indicating that deeper wells are equally vulnerable to $\mathrm{M} t \mathrm{BE}$ contamination as shallower wells. Ayotte and others (2004) had similar findings with wells depths and hypothesized that deep, low-yielding wells in NECR aquifers need large contributing areas to achieve adequate yields, which in turn, increases the likelihood of intercepting M $t \mathrm{BE}$ contaminated groundwater.

\section{Temporal Variability of Selected Water-Quality Constituents in Groundwater from New England Crystalline Rock Aquifers}

Six of the 28 domestic wells from the NECB well network, where the geologic units are dominated by calcareous metasedimentary rocks, were resampled up to four times for the NAWQA Program from 1999 to 2007 (fig. 40). Biennial sampling occurred during July to remove the potential effects that seasonal sampling might have on water quality. Well depths for the six wells ranged from 100 to 310 feet, and the water-level depth in the wells generally increased as the total depth of the well increased. Although the number of samples is too low for statistical analysis, graphical observations provide initial indications of both potential trends and variability of groundwater quality.

The water levels, $\mathrm{pH}$ values, and concentrations of DO, $\mathrm{NO}_{3}$, As, and $\mathrm{M} t \mathrm{BE}$ for the four sampling events from 1999 to 2007 are shown in figure 41. Samples from three wells (TW3, TW4, and TW6; not shown) had $\mathrm{NO}_{3}$ concentrations below the $\mathrm{LRL}$ of $0.06 \mathrm{mg} / \mathrm{L}$ during the 8-year sampling period. Samples 


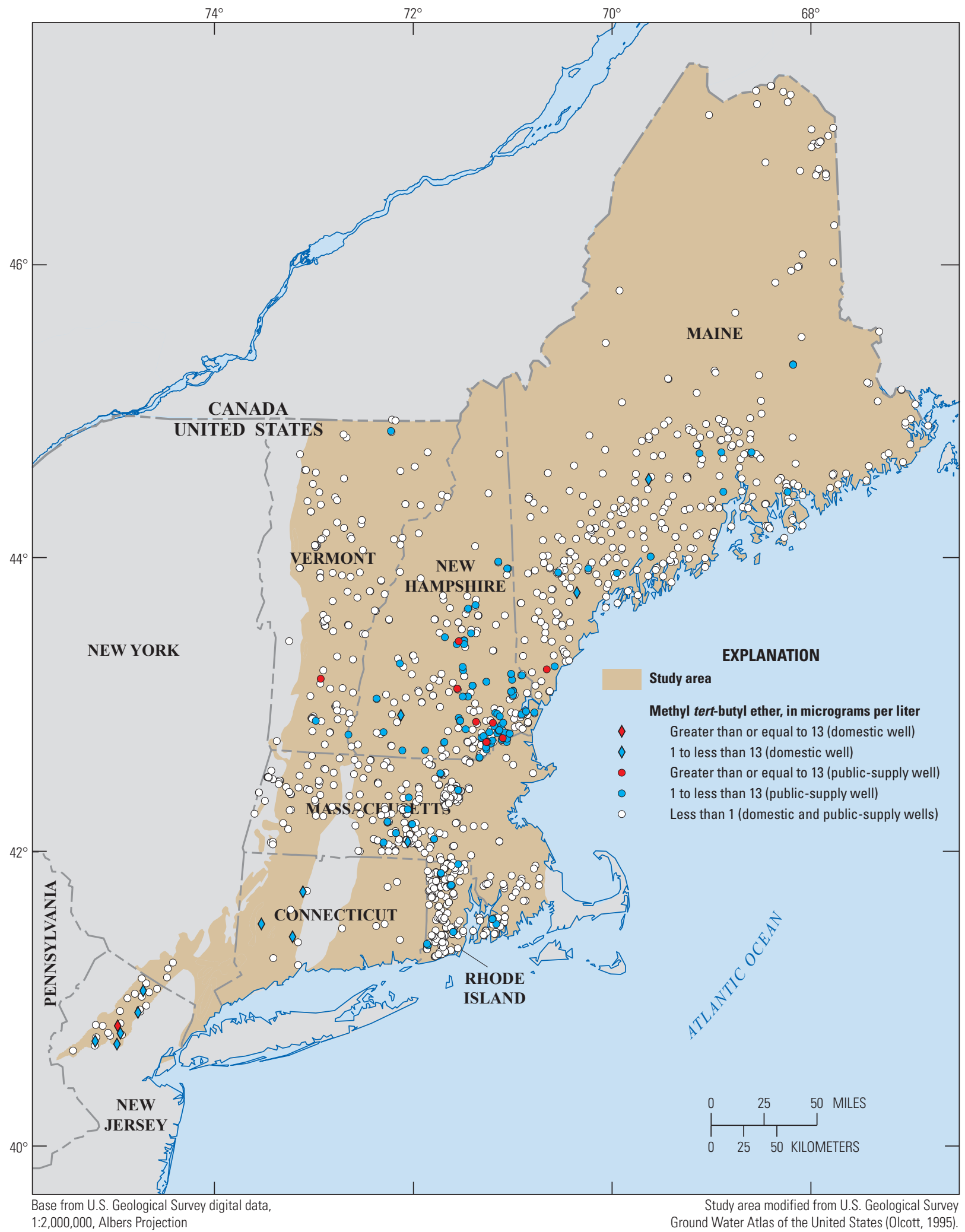

Figure 37. Spatial distribution of methyl tert-butyl ether concentration in water samples collected from domestic and public-supply wells in New England crystalline rock aquifers, 1995-2007. 


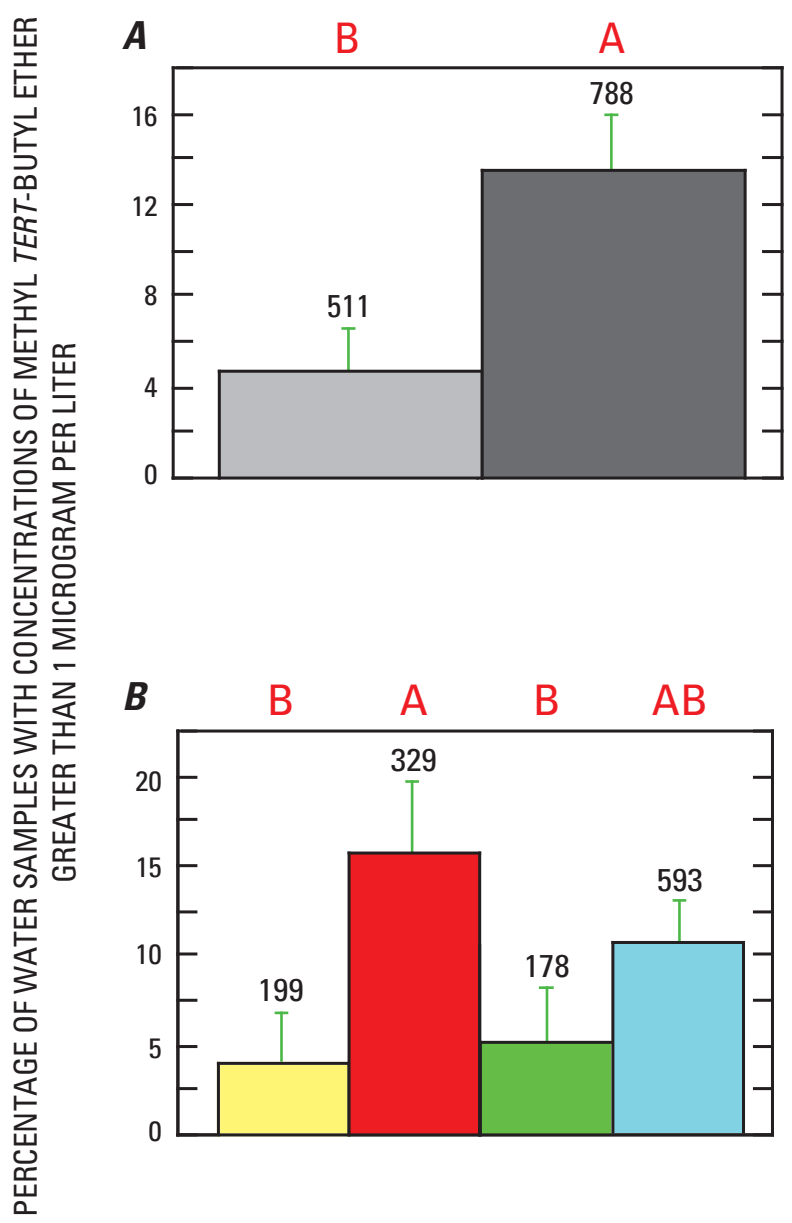

\section{EXPLANATION}

Population density within a 500-meter radius of sampled wells, in 2000

Fewer than 50 persons per square kilometer

Equal to or more than 50 persons per square kilometer

Statistical group from Tukey's test

A Groups with the same letter are not significantly different at an alpha value of 0.05

511 Number of samples

Error bar representing the 95-percent confidence interval of the mean (binomial distribution)

Dominant use of land within a 500-meter radius of sampled wells, in 2001

Agriculture-Agricultural land uses are greater than 15 percent and developed land uses are less than or at 5 percent

$\square$ Developed-Developed (urban) land uses are greater than 25 percent and agricultural land uses are less than or at 15 percent

$\square$ Undeveloped-Undeveloped land uses and land cover are equal to or greater than 85 percent

Mixed-No dominant land use

Statistical group from Tukey's test

A Groups with the same letter are not significantly different at an alpha value of 0.05

199 Number of samples

Error bar representing the 95-percent confidence interval of the mean (binomial distribution)

Figure 38. Distribution of percentages of water samples collected from public-supply and domestic wells in New England crystalline rock aquifers with concentrations of methyl tert-butyl ether greater than 1 microgram per liter, by categories of $A$, population density and $B$, land use, 1995-2007. 

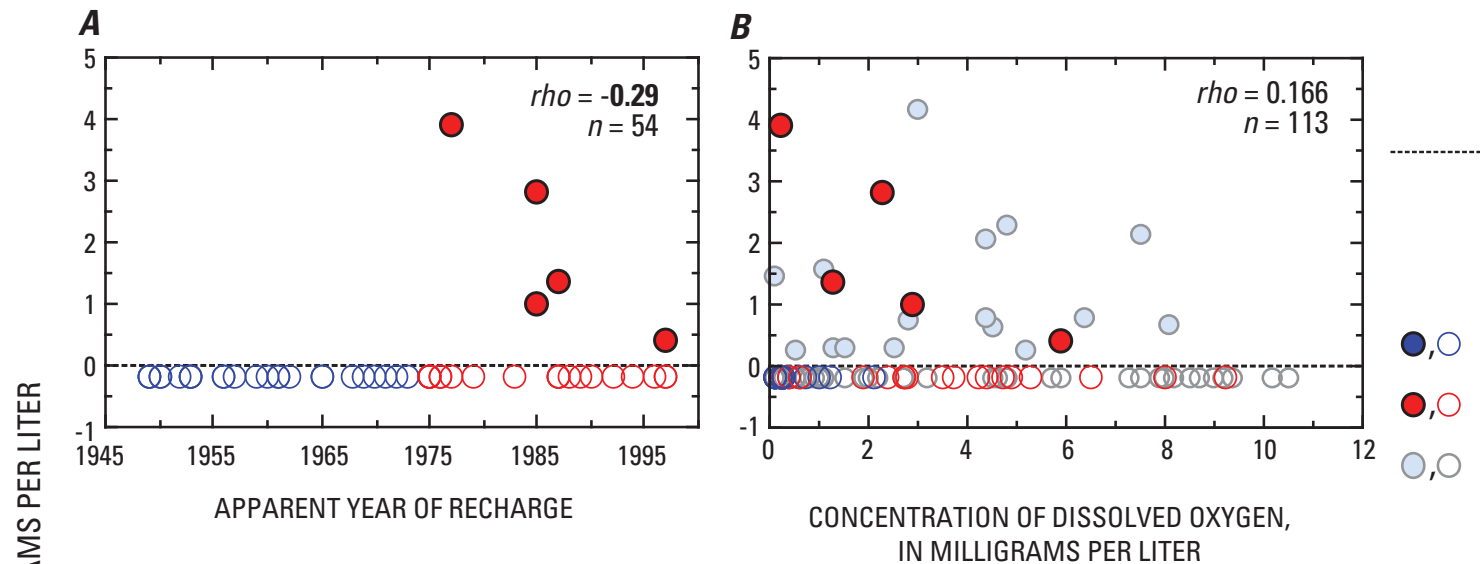

EXPLANATION

Laboratory reporting level

Apparent residence time of water at time of samplingOpen circles represent censored values

Greater than 25 years

Less than or equal to 25 years

Not determined

\section{C}

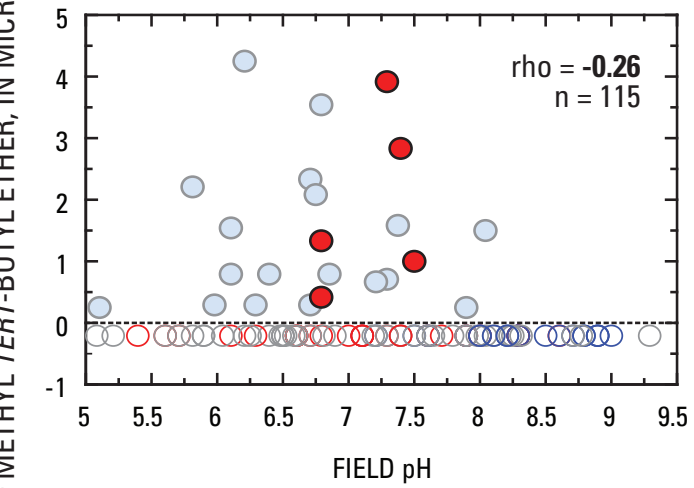

D

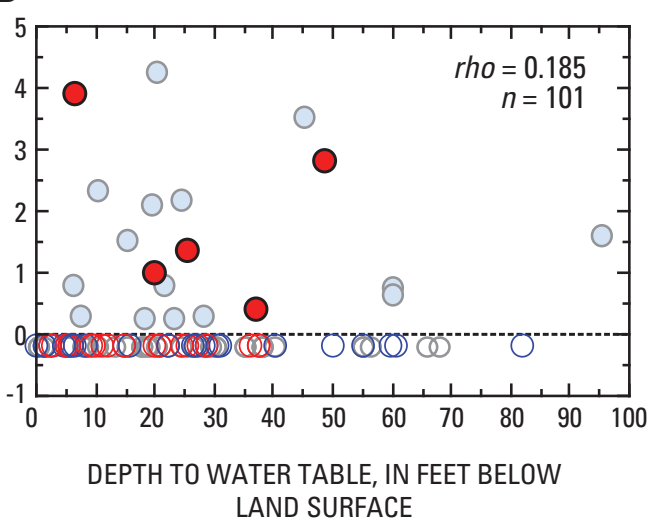

$\boldsymbol{F}$

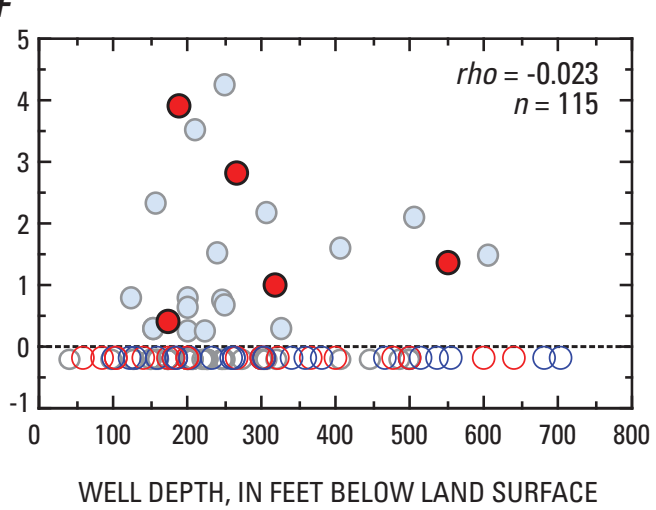

IN FEET BELOW LAND SURFACE

Figure 39. Concentrations of methyl tert-butyl ether in water samples collected from domestic wells in New England crystalline rock aquifers in relation to $A$, apparent year of recharge; $B$, dissolved oxygen concentrations; $C$, field $\mathrm{pH}$; $D$, depth to groundwater table; $E$, depth to bottom of well casing; and $F$, well depth, 1995-2000. Rho coefficient values are from Spearman correlations and are considered significant (in bold) when the probability values are less than 0.05 . Methyl-tert-butyl ether concentrations greater than 5 micrograms per liter are not shown. 


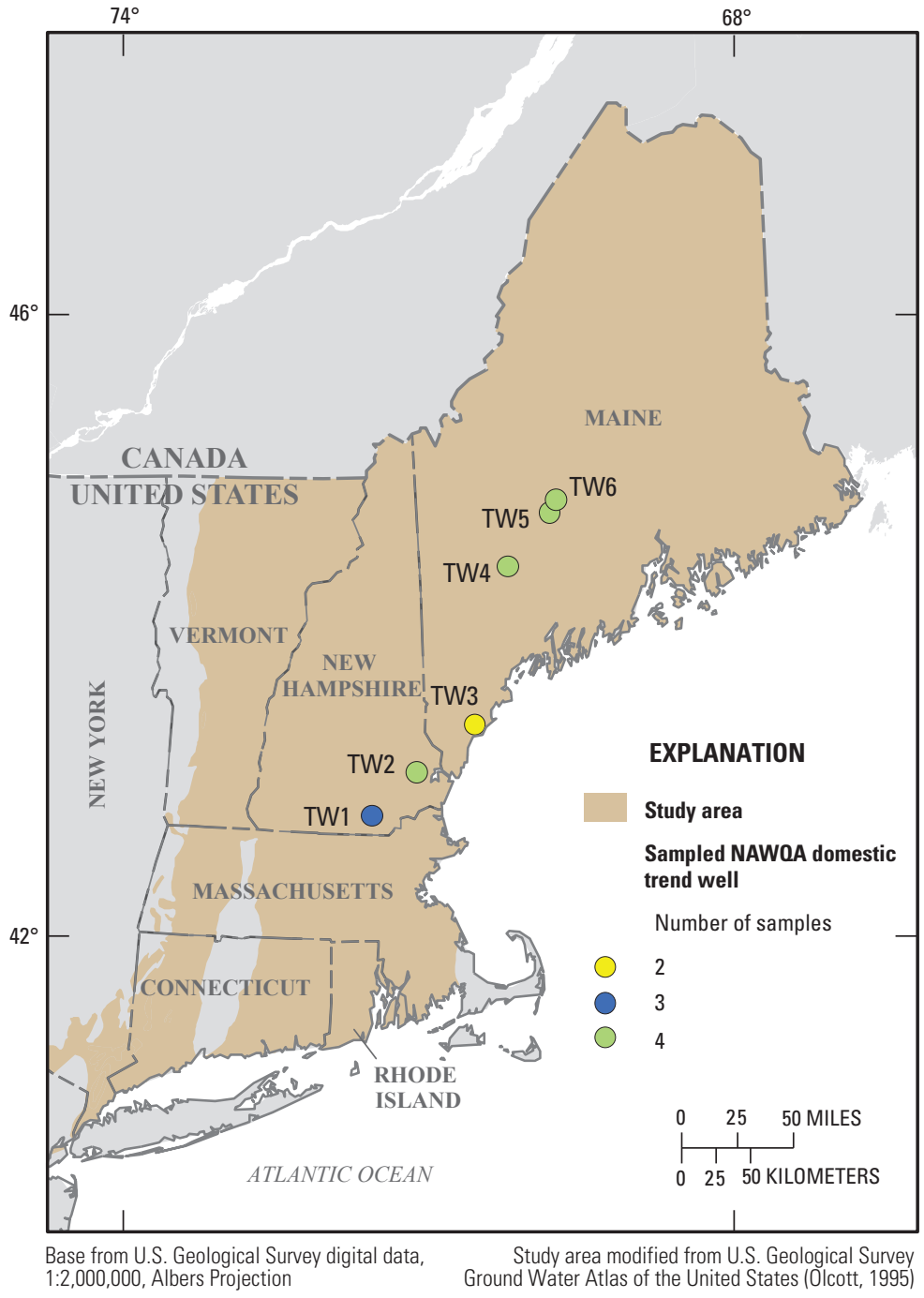

Figure 40. Location of six domestic trend wells in New England crystalline rock aquifers that were sampled biannually for the National Water-Quality Assessment Program to determine trends in selected physiochemical properties and water-quality constituents, 1999-2007. Color of circle represents the number of samples collected from the trend well. from three wells (TW4, TW5, and TW6; not shown) had As concentrations below the LRL of $1 \mu \mathrm{g} / \mathrm{L}$ during the 8 -year sampling period. Two water samples from TW3 (not shown) had $\mathrm{M} t \mathrm{BE}$ concentrations below $0.2 \mu \mathrm{g} / \mathrm{L}$. In general, waterquality conditions were similar at each well over the 8-year period of the study. Three wells yielded oxic water samples (DO $>4 \mathrm{mg} / \mathrm{L}$ ) throughout the 8-year sampling period, and three wells yielded anoxic water samples $(\mathrm{DO}<0.5 \mathrm{mg} / \mathrm{L}$ ) throughout the 8-year sampling period (fig. 41C). Three wells yielded alkaline water samples $(\mathrm{pH}>7)$ throughout the 8 -year sampling period, and two wells yielded acidic water samples $(\mathrm{pH}<7)$ over the 8-year sampling period. One well (TW5) yielded both alkaline and acidic water samples, but over a narrow range of the $\mathrm{pH}$ scale (fig. 41B).
In groundwater from these six trend wells, concentrations of the trace element As varied less than concentrations of the anthropogenic compounds $\mathrm{NO}_{3}$ and $\mathrm{M} t \mathrm{BE}$ (figs. 41D-F). The importance of this observation is that As concentrations in the trend wells were effectively stable over the 8-year sampling period. Since the mobility of As in groundwater is strongly controlled by redox conditions, the relative stability of DO and field $\mathrm{pH}$ may partially explain the stability of As concentrations in the six trend wells.

$\mathrm{M} t \mathrm{BE}$ detections in groundwater depend greatly on the amount and timing of $\mathrm{M} t \mathrm{BE}$ releases in the environment; thus, the concentrations of $\mathrm{M} t \mathrm{BE}$ showed the largest variation over time. However, these variations were small in absolute magnitude and occurred near the lower limits of the LRL (fig. 41F). 

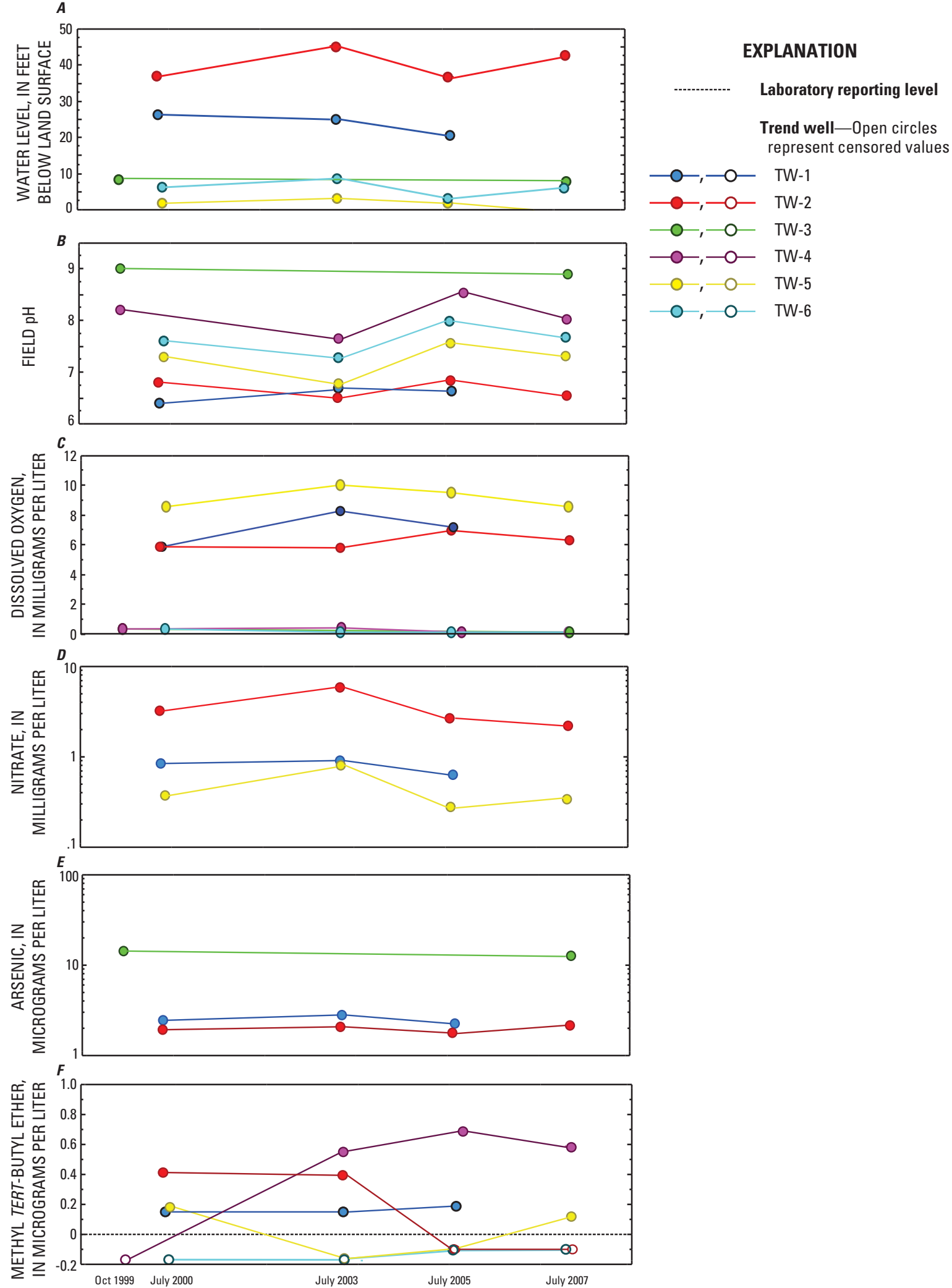

Figure 41. $A$, Water levels, $B$, $\mathrm{pH}$, and concentrations of $C$, dissolved oxygen, $D$, nitrate, $E$, arsenic, and $F$, methyl tert-butyl ether in water samples collected from six domestic trend wells in New England crystalline rock aquifers, 1999-2007. Locations of trend wells shown in figure 40. 


\section{Summary and Conclusions}

The water quality of New England crystalline rock (NECR) aquifers was assessed using water-quality data from 117 domestic wells [88 in New England and 29 in New Jersey and New York (NY-NJ)] sampled for the National WaterQuality Assessment (NAWQA) Program during 1995-2007. This study also assessed data from 4,775 public-supply wells in New England sampled for the U.S. Environmental Protection Agency (USEPA) Safe Drinking Water Act Program during 1997-2007. All water samples used for this study were obtained before any treatment that may have been in place and, thus, do not necessarily represent water that homeowners consumed from their domestic wells or from public-supply wells that deliver drinking water through distribution systems. Some distribution systems are either part of multiwell community water systems or water systems that blend waters from different sources. This study assessed regional waterquality patterns on the basis of lithogeologic setting, land use and population density, well construction properties, and geochemical conditions.

The median $\mathrm{pH}$ of 2,019 sampled wells was 7.6. Nine percent of the $\mathrm{pH}$ values in the sampled wells were below the recommended lower limit of 6.5 , and 4 percent were greater than the recommended upper limit of 8.5. Overall, $\mathrm{pH}$ values were significantly higher in the sampled wells in New England than in the sampled NJ-NY wells. The sampled wells in New England are significantly deeper in depth than the NJ-NY wells and may tap into groundwaters that are older and more chemically evolved, and thus, have higher $\mathrm{pH}$ values.

The apparent residence time (age) of groundwater in samples from 55 domestic wells ranged from 3 to greater than 51 years, with a median value of 25 years. The strong, positive correlation between apparent ages and $\mathrm{pH}$ indicates that high $\mathrm{pH}(>7.5)$ groundwaters are generally associated with older, chemically evolved groundwaters. Concentrations of nitrate $\left(\mathrm{NO}_{3}\right)$, copper $(\mathrm{Cu})$, lead $(\mathrm{Pb})$, nickel $(\mathrm{Ni})$, and zinc $(\mathrm{Zn})$ correlated inversely with apparent ages, indicating that the largest concentrations of these constituents occurred in generally younger groundwater. Concentrations of iron $(\mathrm{Fe})$, manganese $(\mathrm{Mn})$, fluoride $(\mathrm{F})$, lithium $(\mathrm{Li})$, sodium $(\mathrm{Na})$, and molybdenum (Mo) correlated positively with apparent ages, indicating that some of the largest concentrations of these constituents likely occurred in older groundwater.

Nitrate (as N) concentrations in 4,781 water samples from all sampled wells were mostly in the range of $<0.5$ to 1.6 milligrams per liter $(\mathrm{mg} / \mathrm{L})$, with a maximum value of $18.4 \mathrm{mg} / \mathrm{L}$. Only 5 of 4,664 water samples ( 0.1 percent) from the publicsupply wells had $\mathrm{NO}_{3}$ concentrations equal to or greater than the maximum contaminant level (MCL) of $10 \mathrm{mg} / \mathrm{L}$. None of the 117 water samples from the domestic wells had $\mathrm{NO}_{3}$ concentrations equal to or greater than the MCL. In this study, $\mathrm{NO}_{3}$ concentrations greater than $3 \mathrm{mg} / \mathrm{L}-$ a concentration that represents greater than background levels - were present more frequently in groundwater from domestic wells than from public-supply wells, possibly as a result of greater flexibility in siting public-supply wells within community-owned property boundaries.

The major ion chemistry of samples from domestic wells was dominated by calcium-bicarbonate $\left(\mathrm{Ca}-\mathrm{HCO}_{3}\right)$ type waters; calcium-chloride $(\mathrm{Ca}-\mathrm{Cl})$, sodium-chloride $(\mathrm{Na}-\mathrm{Cl})$, sodium-bicarbonate $\left(\mathrm{Na}-\mathrm{HCO}_{3}\right)$, and sodium-sulfate $\left(\mathrm{Na}-\mathrm{SO}_{4}\right)$ type waters were found less frequently. Chloride to bromide $(\mathrm{Cl}: \mathrm{Br})$ mass ratios indicate that the potable groundwater was probably affected by at least three halogen sources: (1) local precipitation and recharge waters, with $\mathrm{Cl}: \mathrm{Br}$ mass ratios ranging from 50 to 200, with $\mathrm{Cl}$ concentrations less than $6 \mathrm{mg} / \mathrm{L}$, and with variable $\mathrm{Na}: \mathrm{Cl}$ molar ratios; (2) seawater and connate waters (evolved from seawater), with $\mathrm{Cl}: \mathrm{Br}$ mass ratios ranging from 200 to 400, with highly variable $\mathrm{Cl}$ concentrations, and with $\mathrm{Na}: \mathrm{Cl}$ molar ratios greater than 1 ; and (3) recharge waters affected by $\mathrm{NaCl}$ sources such as road salt (from mined halite) used for de-icing roadways and possibly discharges from water softeners, with $\mathrm{Cl}: \mathrm{Br}$ mass ratios exceeding 1,000, with $\mathrm{Cl}$ concentrations greater than $30 \mathrm{mg} / \mathrm{L}$, and with $\mathrm{Na}: \mathrm{Cl}$ molar ratios less than 1 . Most of the $\mathrm{Ca}-\mathrm{Cl}$ and $\mathrm{Na}-\mathrm{Cl}$ type waters are probably affected by road de-icing salts dissolved in recharge waters. The high $\mathrm{pH}$ (8 to 9.3) of $\mathrm{Na}-\mathrm{HCO}_{3}$ type waters probably resulted from (1) ion exchange of $\mathrm{Ca}$ for $\mathrm{Na}$ on Na-enriched aquifer materials, from post-glacial seawater inundation, or from connate waters; with $\mathrm{Cl}$ concentrations less than $30 \mathrm{mg} / \mathrm{L}$, and $\mathrm{Na}: \mathrm{Cl}$ molar ratios greater than 1 ; or (2) by extensive water-rock interactions, and leaching of low-sodium granitic rocks, resulting in groundwaters with $\mathrm{Cl}$ concentrations greater than $30 \mathrm{mg} / \mathrm{L}$ and elevated concentrations of $\mathrm{F}(>2 \mathrm{mg} / \mathrm{L})$.

The highest $\mathrm{F}$ concentration in water samples from the sampled wells was $17.9 \mathrm{mg} / \mathrm{L}$. Virtually all F concentrations greater than the MCL of $4 \mathrm{mg} / \mathrm{L}$ were in samples from wells in felsic igneous bedrock. More than 10 percent of wells in alkali granite $\left(\mathrm{I}_{\mathrm{a}}\right)$ had $\mathrm{F}$ concentrations greater than the MCL. Elevated $\mathrm{F}$ concentrations $(>2 \mathrm{mg} / \mathrm{L})$ in the domestic wells generally occurred in older, high $\mathrm{pH}(>8) \mathrm{Na}-\mathrm{HCO}_{3}$ type waters in felsic igneous bedrock enriched in fluorine minerals.

Iron and Mn concentrations in the sampled wells were strongly and positively correlated with each other, suggesting that $\mathrm{Fe}$ and $\mathrm{Mn}$ commonly co-occur in NECR aquifers. Iron concentrations were equal to or greater than the secondary MCL (SMCL) of $300 \mu \mathrm{g} / \mathrm{L}$ in 22 percent of 1,632 sampled wells. Manganese concentrations were equal to or greater than the SMCL of $50 \mu \mathrm{g} / \mathrm{L}$ in 38 percent of 1,759 sampled wells and were equal to or greater than the USEPA lifetime health advisory level (LHA) of $300 \mu \mathrm{g} / \mathrm{L}$ in 7.3 percent of these wells. Water samples from wells in the $\mathrm{M}_{\mathrm{nb}}$ lithology group had significantly higher concentrations of $\mathrm{Fe}$ and $\mathrm{Mn}$ than the other studied lithology groups. Iron and Mn concentrations were significantly greater in the public-supply well samples than in the domestic well samples. The difference in sample collection (filtered samples from the NAWQA wells and unfiltered samples from the SDWA wells) may explain the differences in $\mathrm{Fe}$ and $\mathrm{Mn}$ concentrations between the two data programs. 
Arsenic (As) concentrations in 2,054 water samples collected from the domestic and public-supply wells were mostly in the range of $<5$ to $13 \mu \mathrm{g} / \mathrm{L}$; the maximum concentration was $2,400 \mu \mathrm{g} / \mathrm{L}$. For the 2,054 wells studied, 13.3 percent of water samples had As concentrations greater than the MCL [10 micrograms per liter $(10 \mu \mathrm{g} / \mathrm{L})$ ], nearly double the national rate for community-supply systems and domestic wells in the United States. Arsenic concentrations in samples from studied wells in the belt of calcareous metasedimentary rocks in the New Hampshire-Maine geologic province $\left(M_{c}-n m\right)$, in peraluminous granite $\left(\mathrm{I}_{\mathrm{p}}\right)$, and in pelitic rocks $\left(\mathrm{M}_{\mathrm{p}}\right)$ were significantly higher than in all other lithology groups studied, and wells in $\mathrm{M}_{\mathrm{c}}$-nm rocks had a greater percentage of samples with As concentrations greater than the MCL. Elevated As concentrations in domestic well samples tended to occur in these high-arsenic rock lithologies under conditions of low DO $(<1 \mathrm{mg} / \mathrm{L})$ and of high $\mathrm{pH}(>7.5)$, probably as a result of the release of sorbed As from $\mathrm{Fe}$ oxides by reductive dissolution or by desorption from Fe oxides.

High As concentrations ( $>10 \mu \mathrm{g} / \mathrm{L})$ occurred in nearly 20 percent of domestic well samples where well depths exceeded 300 feet (ft) and casing lengths exceeded $50 \mathrm{ft}$ compared to only 6 percent of samples where well depths were less than $300 \mathrm{ft}$ and casing lengths were less than $50 \mathrm{ft}$. This is not surprising since deep bedrock wells with long casing lengths are more likely to tap into fractures yielding older, high- $\mathrm{pH}$ groundwater than shallower wells - a condition that favors As mobility.

Gross alpha activities equaled or exceeded the MCL in 15.5 percent of water samples from 57 domestic wells and in 11.6 percent of water samples from 835 public-supply wells, and were highest in wells completed in peraluminous ( $\left.\mathrm{I}_{\mathrm{p}}\right)$ and alkali $\left(\mathrm{I}_{\mathrm{a}}\right)$ granite rocks. Five samples (9 percent) from 58 domestic wells had gross beta-particle activities equal to or greater than the USEPA screening level of 50 picocuries per liter ( $\mathrm{pCi} / \mathrm{L})$. Activities of combined radium $\left({ }^{226} \mathrm{Ra}\right.$ plus $\left.{ }^{228} \mathrm{Ra}\right)$ were equal to or greater than the MCL in 2 water samples (about 4 percent) from the 56 domestic wells in New England and in 16 water samples ( 3.15 percent) from 508 public-supply wells.

The median radon activities in the water samples were $2,060 \mathrm{pCi} / \mathrm{L}$ for 112 domestic wells and 2,600 pCi/L for 831 public-supply wells. Ninety-five percent of water samples from these 943 wells had radon activities greater than the proposed MCL of $300 \mathrm{pCi} / \mathrm{L}$, and 33 percent had radon activities greater than the proposed alternative MCL (AMCL) of 4,000 pCi/L. Radon activities were highest for wells in alkali granite $\left(\mathrm{I}_{\mathrm{a}}\right)$, peraluminous granite $\left(\mathrm{I}_{\mathrm{p}}\right)$, and Narragansett metasedimentary $\left(\mathrm{M}_{\mathrm{nb}}\right)$ rocks.

The maximum U concentrations were $429 \mu \mathrm{g} / \mathrm{L}$ in samples from 117 domestic wells and 3,640 $\mu \mathrm{g} / \mathrm{L}$ in samples from 439 public-supply wells. Uranium concentrations were greater than the MCL in 4.3 percent of the water samples from the domestic wells and in 16.9 percent from the publicsupply wells. Uranium concentrations greater than the MCL of $30 \mu \mathrm{g} / \mathrm{L}$ occurred more frequently (47.4 percent) in water samples from wells in the peraluminous granite $\left(\mathrm{I}_{\mathrm{p}}\right)$ lithology group than in samples from all other studied lithology groups. Using Spearman correlation, U concentrations in the water samples were significantly correlated with activities of gross alpha, gross beta, radon, and combined radium, indicating that uranium is a useful indicator in assessing the overall radioactivity of groundwater from NECR aquifers.

When detected, all pesticide concentrations were estimated, and no concentration exceeded human health benchmarks. Thirty-one water samples from 114 domestic wells (about 27 percent) contained one or more pesticides, detected at an estimated concentration equal to or greater than $0.001 \mu \mathrm{g} / \mathrm{L}$, and 7 of the 114 domestic well samples (about 6 percent) contained one or more pesticides, detected at concentrations equal to or greater than $0.01 \mu \mathrm{g} / \mathrm{L}$. Of 47 pesticide analytes, 6 herbicides (atrazine, EPTC, metolachlor, prometon, pronamide, and simazine), 2 pesticide degradates (deethylatrazine, p-p'-DDE), and 1 insecticide (dieldrin) were detected in 114 domestic well samples at estimated concentrations greater than $0.001 \mu \mathrm{g} / \mathrm{L}$; four of these compounds (atrazine, deethylatrazine, metolachlor, and prometon) were detected at concentrations greater than $0.01 \mu \mathrm{g} / \mathrm{L}$. Two pesticide compounds - deethylatrazine, a degradate of atrazine (18 percent frequency detection) and atrazine ( 8 percent frequency detection) - were detected $(\geq 0.001 \mu \mathrm{g} / \mathrm{L})$ in more than 3 percent of the sampled domestic wells. The largest pesticide concentration measured was an estimated concentration of $0.06 \mu \mathrm{g} / \mathrm{L}$ for metolachlor, an herbicide that is relatively soluble in water, from a NJ-NY domestic well.

At the $0.02 \mu \mathrm{g} / \mathrm{L}$ threshold level, $\mathrm{M} t \mathrm{BE}$, a fuel additive, and chloroform, a trihalomethane, were the two most frequently detected ( 36 and 32.9 percent, respectively) VOCs in samples from 86 domestic wells. The most common mixture of volatile organic compounds (VOCs) in the domestic wells with two or more measureable concentrations $(\geq 0.02 \mu \mathrm{g} / \mathrm{L}$ ) was chloroform and $\mathrm{M} t \mathrm{BE}$. Twelve of the 25 water samples from 86 domestic wells with measureable chloroform $(\geq 0.02 \mu \mathrm{g} / \mathrm{L})$ had measureable $\mathrm{M} t \mathrm{BE}(\geq 0.02 \mu \mathrm{g} / \mathrm{L})$.

The maximum chloroform concentration was $2.82 \mu \mathrm{g} / \mathrm{L}$ in water samples from 115 domestic wells. None of the samples collected from the domestic wells had chloroform concentrations greater than the MCL of $80 \mu \mathrm{g} / \mathrm{L}$ that the USEPA established for total trihalomethanes (TTHMs). Chloroform concentrations in samples from the domestic wells were correlated most strongly and positively with concentrations of $\mathrm{NO}_{3}, \mathrm{M} t \mathrm{BE}, \mathrm{Cl}$, and total dissolved solids. The maximum $\mathrm{M} t \mathrm{BE}$ concentrations were $30.2 \mu \mathrm{g} / \mathrm{L}$ in samples from the domestic wells and $190 \mu \mathrm{g} / \mathrm{L}$ in samples from the public-supply wells. Only 6 of 1,299 samples from the domestic and public-supply wells exceeded the USEPA advisory level of 20 to $40 \mu \mathrm{g} / \mathrm{L}$ for M $t$ BE. $\mathrm{M} t \mathrm{BE}$ concentrations in water samples from the studied wells correlated positively with concentrations of specific conductance, $\mathrm{Cl}$, chloroform, and with percentage of developed lands and population density surrounding the wells. 
$\mathrm{M} t \mathrm{BE}$ concentrations in water samples from domestic wells correlated inversely with apparent residence time (age) of water and with $\mathrm{pH}$, indicating that younger groundwaters in NECR aquifers are more vulnerable to MtBE contamination than are older groundwaters. Water samples with apparent ages less than 25 years had more detections of MtBE than water samples with older apparent ages. This finding is consistent with the time period of high $\mathrm{M} t \mathrm{BE}$ use in areas in the United States where reformulated gasoline was mandated. In contrast to $\mathrm{NO}_{3}, \mathrm{M} t \mathrm{BE}$ concentrations in NECR aquifers did not correlate with well depth, suggesting that their loading, transport and degradation rates differ.

Six of the 28 domestic wells from the NECB well network where the geologic units are dominated by calcareous metasedimentary rocks were resampled up to four times from 1999 to 2007. In general, DO and field pH were similar for each well over the 8-year period. In groundwater from these six trend wells, concentrations of the trace element As varied less than concentrations of the anthropogenic compounds $\mathrm{NO}_{3}$ and $\mathrm{M} t \mathrm{BE}$. Since the mobility of As in groundwater is strongly controlled by redox conditions, the relative stability of DO and field $\mathrm{pH}$ may partially explain the stability of As concentrations in the six trend wells. MtBE detections in groundwater depend greatly on the amount and timing of $\mathrm{M} t \mathrm{BE}$ releases in the environment; thus, the concentrations of $\mathrm{M} t \mathrm{BE}$ showed the largest variation over time.

The frequency of detections above human health benchmarks or advisory levels, for a wide variety of contaminants studied- $\mathrm{Na}, \mathrm{Cl}, \mathrm{F}, \mathrm{Fe}, \mathrm{Mn}$, As, gross alpha, combined radium, radon, uranium, and MtBE-in both domestic and public-supply wells shows the vulnerability of NECR aquifers to naturally occurring and anthropogenic contamination. The highly variable water quality and the association with highly variable lithology of crystalline bedrock underscores the importance of testing individual wells to determine if concentrations for the most commonly detected contaminants exceed human health benchmarks or advisory levels.

\section{References Cited}

Agency for Toxic Substances and Disease Registry, 2008, Public health statement-manganese: U.S. Department of Health and Human Services, Public Health Service, September 2008, accessed June 25, 2009, at http://www.atsdr.cdc.gov/toxprofiles/tp151-c1-b.pdf.

Apodaca, L.E., Mueller, D.K., and Koterba, M.T., 2006, Review of trace element blank and replicate data collected in ground and surface water for the National Water-Quality Assessment Program, 1991-2002: U.S. Geological Survey Scientific Investigations Report 2006-5093, 32 p.
Ayers, M.A., Kennen, J.G., and Stackelberg, P.E., 2000, Water quality in the Long Island-New Jersey coastal drainages, New York and New Jersey, 1996-98: U.S. Geological Survey Circular 1201, 40 p.

Ayotte, J.D., Argue, D.M., and McGarry, F.J., 2005, Methyl tert-butyl ether occurrence and related factors in public and private wells in southeastern New Hampshire: Environmental Science and Technology, v. 39, no. 1, p. 9-16.

Ayotte, J.D., Argue, D.M., McGarry, F.J., Degnan, J.R., Hayes, Laura, Flanagan, S.M., and Helsel, D.R., 2008, Methyl tert-butyl ether (MTBE) in public and private wells in New Hampshire - Occurrence, factors, and possible implications: Environmental Science and Technology, v. 42 , no. 3 , p. $677-684$.

Ayotte, J.D., Flanagan, S.M., and Morrow, W.S., 2007, Occurrence of uranium and ${ }^{222}$ radon in glacial and bedrock aquifers in the northern United States, 1993-2003: U.S. Geological Survey Scientific Investigations Report 2007-5037, 84 p.

Ayotte, J.D., Montgomery, D.L., Flanagan, S.M., and Robinson, K.W., 2003, Arsenic in groundwater in eastern New England: Occurrence, controls, and human health implications: Environmental Science and Technology, v. 37 , no. 10 , p. $2075-2083$.

Ayotte, J.D., Mrazik, B.R., Argue, D.M., and McGarry, F.J., 2004, Occurrence of methyl tert-butyl ether (MTBE) in public and private wells, Rockingham County, New Hampshire: U.S. Geological Survey Fact Sheet 2004-3119, 4 p. (Also available at http://pubs.water.usgs.gov/ FS2004-3119.)

Ayotte, J.D., Nielsen, M.G., Robinson, G.R., Jr., and Moore, R.B., 1999, Relation of arsenic, iron, and manganese in ground water to aquifer type, bedrock lithogeochemistry, and land use in the New England Coastal Basins: U.S. Geological Survey Water-Resources Investigations Report 99-4162, $61 \mathrm{p}$.

Ayotte, J.D., Nolan, B.T., Nuckols, J.R., Cantor, K.P., Robinson, G.R., Baris, D., Hayes, L., Karagas, M., Bress, W., Silverman, D.T., and Lubin, J.H., 2006, Modeling the probability of arsenic in groundwater in New England as a tool for exposure assessment: Environmental Science \& Technology, v. 40, no. 11, p. 3578-3585.

Barbash, J.E., Thelin, G.P., Kolpin, D.W., and Gilliom, R.J., 1999, Distribution of major herbicides in ground water of the United States: U.S. Geological Survey Water-Resources Investigations Report 98-4245, 58 p.

Barbash, J.E., Thelin, G.P., Kolpin, D.W., and Gilliom, R.J., 2001, Major herbicides in ground water-Results from the National Water-Quality Assessment: Journal of Environmental Quality, v. 30, p. 831-845. 
Barlow, P.M., 2003, Ground water in freshwater-saltwater environments of the Atlantic Coast: U.S. Geological Survey Circular 1262, 121 p. (Also available at http://pubs.usgs.gov/circ/2003/circ1262/pdf/circ1262.pdf.)

Bender, D.A., Zogorski, J.S., Mueller, D.K., Rose, D.L., Martin, J.D., and Brenner, C.K., 2011, Quality of volatile organic compound data from groundwater and surface water for the National Water-Quality Assessment Program, October 1996-December 2008: U.S. Geological Survey Scientific Investigations Report 2011-5204, 128 p. (Accessed at http://pubs.usgs.gov/sir/2011/5204/.)

Bowser, C.J., and Jones, B.F., 2002, Mineralogic controls on the composition of natural waters dominated by silicate hydrolysis: American Journal of Science, v. 302, September, p. 582-662.

Boyer, E.W., Goodale, C.L., Jaworski, N.A., and Howarth R.W., 2002, Anthropogenic nitrogen sources and relationships to riverine nitrogen export in the northeastern U.S.A.: Biogeochemistry, v. 57/58, p. 137-169.

Brenton, R.W., and Arnett, T.L., 1993, Methods of analysis by the U.S. Geological Survey National Water Quality Laboratory-Determination of dissolved organic carbon by uv-promoted persulfate oxidation and infrared spectrometry: U.S. Geological Survey Open-File Report 92-480, 12 p. (Also available at http://pubs.usgs.gov/of/1992/0480/ report.pdf.)

Carter, J.M., Lapham, W.W., and Zogorski, J.S., 2008, Occurrence of volatile organic compounds in aquifers of the United States: Journal of the American Water Resources Association, v. 44, no. 2, p. 399-416.

Chae, G.T., Yun, S.T., Kim, Kangjoo, and Mayer, Bernhard, 2006, Hydrogeochemistry of sodium-bicarbonate type bedrock groundwater in the Pocheon spa area, South Korea-Water-rock interaction and hydrologic mixing: Journal of Hydrology, v. 321, p. 326-343.

Childress, C.J., Oblinger, Foreman, W.T., Conner, B.F., and Maloney, T.J., 1999, New reporting procedures based on long-term method detection levels and some considerations for interpretations of water-quality data provided by the U.S. Geological Survey National Water Quality Laboratory: U.S. Geological Survey Open-File Report 99-193, 19 p.

Conner, B.F., Rose, D.L., Noriega, M.C., Murtagh, L.K., and Abney, S.R., 1998, Methods of analysis by the U.S. Geological Survey National Water Quality LaboratoryDetermination of 86 volatile organic compounds in water by gas chromatography/mass spectrometry, including detections less than reporting limits: U.S. Geological Survey Open-File Report 97-829, 78 p.

Coplen, T.B., Wildman, J.D., and Chen, J., 1991, Improvements in the gaseous hydrogen-Water equilibrium technique for hydrogen isotope analysis: Analytical Chemistry, v. 63, p. 910-912.
Davis, S.N., Fabryka-Martin, J.T., and Wolfsberg, Laura, 2004, Variations of bromide in potable ground water in the United States: Ground Water, v. 42, no. 6, p. 902-909.

Davis, S.N., Whittemore, D.O., and Fabryka-Martin, J.T., 1998, Uses of chloride/bromide ratios in studies of potable water: Ground Water, v. 36, no. 2, p. 338-350.

Degnan, J.R., Walsh, G.J., Flanagan, S.M., and Burruss, R.C., 2008, Bedrock, borehole, and water-quality characterization of a methane-producing water well in Wolfeboro, New Hampshire: U.S. Geological Survey Open-File Report 2008-1333, 47 p. (Also available at http://pubs.usgs.gov/ of $/ 2008 / 1333 /)$

DeSimone, L.A., 2009, Quality of water from domestic wells in principal aquifers of the United States, 1991-2004: U.S. Geological Survey Scientific Investigations Report 2008-5227, 139 p. (Also available at http://pubs.usgs.gov/ sir/2008/5227.)

DeSimone, L.A., Hamilton, P.A., and Gilliom, R.J., 2009, Quality of water from domestic wells in principal aquifer of the United States, 1991-2004-Overview of major findings: U.S. Geological Survey Circular 1332, 61 p.

Dostal, Jaroslav, and Capedri, Silvio, 1978, Uranium in metamorphic rocks: Contributions to Mineralology and Petrology, v. 66, p. 409-414.

Edmunds, W.M., and Smedley, P.L., 1996, Groundwater geochemistry and health: an overview, in Appleton, Fuge and others, eds., Environmental geochemistry and health: Geological Society Special Publication no. 113, p. 91-105.

Elliott, E.M., Kendall, C., Wankel, S.D., Burns, D.A., Boyer, E.W., Harlin, K., Bain, D.J., and Butler, T.J., 2007, Nitrogen isotopes as indicators of $\mathrm{NO}_{\mathrm{x}}$ source contributions to atmospheric nitrate deposition across the midwestern and northeastern United States: Environmental Science and Technology, v. 41, no. 22, p. 7661-7667.

Epstein, S., and Mayeda, T., 1953, Variation of $\mathrm{O}^{18}$ content of water from natural sources: Geochemimica et Cosmochimica Acta, v. 4, no. 5, p. 213-224.

Flanagan, S.M., Nielsen, K.W., Robinson, K.W., and Coles, J.F., 1999, Water-quality assessment of the New England coastal basins in Maine, Massachusetts, New Hampshire, and Rhode Island-Environmental settings and implications for water quality and aquatic biota: U.S. Geological Survey Water-Resources Investigations Report 98-4249, 78 p. (Also available at http://pubs.water.usgs.gov/wrir98-4249.)

Focazio, M.J., Szabo, Zoltan, Kraemer, T.F., Mullin, A.H., Barringer, T.H., and DePaul, V.T., 2001, Occurrence of selected radionuclides in ground water used for drinking water in the United States - A reconnaissance survey, 1998: U.S. Geological Survey Water-Resources Investigations Report 00-4273, 40 p. 
Focazio, M.J., Welch, A.H., Watkins, S.A., Helsel, D.R., and Horn, M.A., 2000, A retrospective analysis on the occurrence of arsenic in ground water resources of the United States and limitations in drinking-water-supply characterizations: U.S. Geological Survey Water-Resources Investigations Report 99-4279, 27 p.

Frengstad, Bjorn, Banks, David, and Siewers, Ulrich, 2001, The chemistry of Norwegian groundwatersIV. The $\mathrm{pH}$-dependence of element concentrations in crystalline bedrock groundwater: The Science of the Total Environment, v. 277, p. 101-117.

Frengstad, Bjørn, Kjersti, Aase, Midtgard Skrede, Midtgard, Banks, David, Reidar Krog, Jan, and Siewers, Ulrich, 2000, The chemistry of Norwegian groundwaters - III. The distribution of trace elements in 476 crystalline bedrock groundwaters, as analysed by ICP-MS techniques: The Science of the Total Environment, v. 246, p. 21-40.

Furlong, E.T., Anderson, B.D., Werner, S.L., Soliven, P.P., Coffey, L.J., and Burkhardt, M.R., 2001, Methods of analysis by the U.S. Geological Survey National Water Quality Laboratory-Determination of pesticides in water by graphitized carbon-based solid-phase extraction and high-performance liquid chromatography/mass spectrometry: U.S. Geological Survey Water-Resources Investigations Report 01-4134, 73 p.

Garabedian, S.P., Coles, J.F., Grady, S.J., Trench, E.C.T., and Zimmerman, M.J., 1998, Water-quality assessment of the Connecticut, Housatonic, and Thames River Basins, 1991-95: U.S. Geological Survey Circular 1155, 32 p.

Garbarino, J.R., Kanagy, L.K., and Cree, M.E., 2006, Determination of elements in natural-water, biota, sediment and soil samples using collision/reaction cell inductively coupled plasma-mass spectrometry: U.S. Geological Survey Techniques and Methods, book 5, sec. B, chap. 1, 88 p. (Also available at http://pubs.usgs.gov/tm/2006/ tm5b1/.)

Gilliom, R.J., Barbash, J.E., Crawford, C.G., Hamilton, P.A., Martin, J.D., Nakagaki, N., Nowell, L.H., Scott, J.C., Stackelberg, P.E., Thelin, G.P., and Wolock, D.M., 2006, Pesticides in the nation's streams and ground water, 1992-2001: U.S. Geological Survey Circular 1291, 172 p.

Goldich, S.S., 1938, A study in rock weathering: Journal of Geology, v. 46, p. 17-56.

Grady, S.J., and Mullaney, J.R., 1998, Natural and human factors affecting shallow water quality in surficial aquifers in the Connecticut, Housatonic, and Thames River basins: U.S. Geological Survey Water-Resources Investigations Report 98-4042, 81 p.
Guillard, Karl, 2008, New England regional nitrogen and phosphorus fertilizer and associated management practice recommendations for lawns based on waterquality considerations: The University of Maine Cooperative Extension, accessed October 18, 2009, at http://www.extension.umaine.edu/waterquality/Landscapes/ fertilizers.htm.

Hanson, B.P., and Simcox, A.C., 1994, Yields of bedrock wells in Massachusetts: U.S. Geological Survey Water-Resources Investigations Report 93-4115, 43 p.

Harte, P.T., Robinson, G.R., Jr., Ayotte, J.D., and Flanagan, S.M., 2008, Framework for evaluating water quality of the New England crystalline rock aquifers: U.S. Geological Survey Open-File Report 2008-1282, 47 p. (Also available at http://pubs.usgs.gov/ofr/2008/1282.)

Helsel, D.R., 2005, Nondetects and data analysis-Statistics for censored environmental data: Hoboken, N.J., John Wiley, $250 \mathrm{p}$.

Helsel, D.R., and Hirsch, R.M., 1992, Statistical methods in water resources: Elsevier Science Publishing Company, Inc., New York, N.Y., 522 p.

Helsel, D.R., and Hirsch, R.M., 2002, Statistical methods in water resources: Techniques of Water-Resources Investigations of the U.S. Geological Survey, book 4, chap. A3, 522 p. (Also available at http://pubs.usgs.gov/ twri/twri4a3/)

Hem, J.D., 1985, Study and interpretation of the chemical characteristics of natural water ( $3 \mathrm{~d}$ ed.): U.S. Geological Survey Water-Supply Paper 2254, 263 p.

Hess, C.T., Michel, J., Horton, T.R., Prichard, H.M., and Coniglio, W.A., 1985, The occurrence of radioactivity in public water supplies in the United States: Health Physics, V. 48 , no. 5, p. 553-586.

Hinkle, S.R., Shapiro, S.D., Plummer, N.L., Busenberg, Eurybiades, Widman, P.K., Casile, G.C., and Wayland, J.E., 2010, Estimates of tracer-based piston-flow ages of groundwater from selected sites-National Water-Quality Assessment Program, 1992-2005: U.S. Geological Survey Scientific Investigations Report 2010-5229, 102 p.

Hitchcock, C.H., 1878, The geology of New Hampshire: New Hampshire Geological and Mineralogical Survey, Concord, N.H., 3 vols., parts 4 and 5, 386 p.

Ivahnenko, Tamara, and Barbash, J.E., 2004, Chloroform in the hydrologic system - sources, transport, fate, occurrence, and effects on human health and aquatic organisms: U.S. Geological Survey Scientific Investigations Report 2004-5137, 34 p.

Ivahnenko, Tamara, and Zogorski, J.S., 2006, Sources and occurrence of chloroform and other trihalomethanes in drinking-water supply wells in the United States, 19862001: U.S. Geological Survey Scientific Investigations Report 2006-5015, 13 p. 
Kernan, Brandon, 2010, Rock blasting and water quality measures that can be taken to protect water quality and mitigate impacts: New Hampshire Department of Environmental Services Fact-Sheet WD-10-12, 7 p.

Kolpin, D.W., Barbash, J.E., and Gilliom, R.J., 1998, Occurrence of pesticides in shallow groundwater of the United States-Initial results for the National Water-Quality Assessment: Environmental Science \& Technology, v. 32, p. 558-566.

Kontis, A.L., Randall, A.D., and Mazzaferro, D.L., 2004, Regional hydrology and simulation of flow of stratifieddrift aquifers in the glaciated northeastern United States: U.S. Geological Survey Professional Paper 1415-C, 156 p.

Koterba, M.T., Wilde, F.D., and Lapham, W.W., 1995, Ground-water data-collection protocols and procedures for the National Water-Quality Assessment ProgramCollection and documentation of water-quality samples and related data: U.S. Geological Survey Open-File Report 99-399, $113 \mathrm{p}$.

Lapham, W.W., Hamilton, P.A., and Myers, D.N., 2005, National Water-Quality Assessment Program-Cycle IIRegional assessment of aquifers: U.S. Geological Survey Fact Sheet 2005-3013, 4 p. (Also available at http://pubs.usgs.gov/fs/2005/3013/pdf/PASforWeb.pdf.)

Lapham, W.W., Wilde, F.D., and Koterba, M.T., 1995, Ground-water data-collection protocols and procedures for the National Water-Quality Assessment ProgramSelection, installation, and documentation of wells, and collection of related data: U.S. Geological Survey OpenFile Report 95-398, 69 p.

Lipfert, Gail, Reeve, A.S., Sidle, W.C., and Marvinney, Robert, 2006, Geochemical patterns of arsenic-enriched ground water in fractured, crystalline bedrock, Northport, Maine, U.S.A.: Applied Geochemistry, v. 21, p. 528-545.

Maine Department of Human Services, 1998, The presence of MTBE and other gasoline compounds in Maine's drinking water, a preliminary report: Augusta, Maine, Maine Department of Human Services, Bureau of Health, October 13, 1998, 24 p.

Martin, J.D., and Eberle, Michael, 2011, Adjustment of pesticide concentrations for temporal changes in analytical recovery, 1992-2010: U.S. Geological Survey Data Series 630, 11 p., 5 appendixes (Accessed at http://pubs.usgs.gov/ds/630/)

Martin, J.D., Stone, W.W., Wydoski, D.S., and Sandstrom, M.W., 2009, Adjustment of pesticide concentrations for temporal changes in analytical recovery, 1992-2006: U.S. Geological Survey Scientific Investigations Report 2009-5189, 23 p., plus appendixes. (Accessed at http://pubs.usgs.gov/sir/2009/5189/.)
Maupin, M.A., and Arnold, T.L., 2010, Estimates for selfsupplied domestic withdrawals and population served for selected principal aquifers, Calendar Year 2005: U.S. Geological Survey Open-File Report 2010-1223, 10 p. (Also available at $\mathrm{http}: / /$ pubs.usgs.gov/of/2010/1223/.)

Maupin, M.A., and Barber, N.L., 2005, Estimated withdrawals from principal aquifers in the United States: U.S. Geological Survey Circular 1279, 46 p. (Also available at http://pubs.usgs.gov/circ/2005/1279/.)

McCurdy, D.E., Garbarino, J.R., and Mullin, A.H., 2008, Interpreting and reporting radiological water-quality data: U.S. Geological Survey Techniques and Methods, book 5, Laboratory Analysis Section B, chap. 6, 33 p.

Mondal, N.C., Prasad, R.K., Saxena, V.K., Singh, Y., and Singh, V.S., 2009, Appraisal of highly fluoride zones in groundwater of Kurmapalli watershed, Nalgonda district, Andhra Pradesh (India): Environmental Earth Science, v. 59 , p. $63-73$.

Montgomery, D.L., Ayotte, J.D., Carroll, P.R., and Hamlin, Patricia, 2003, Arsenic concentrations in private bedrock wells in southeastern New Hampshire: U.S. Geological Survey Fact Sheet FS 051-03, 6 p. (Also available at http://pubs.water.usgs.gov/fs-051-03.)

Montgomery, D.L., Robinson, G.R., Jr., Robinson, K.W., Ayotte, J.D., and Flanagan, S.M., 2002, Digital data set of generalized lithogeochemical characteristics of near-surface bedrock in the New England coastal basins: U.S. Geological Survey Fact Sheet 2002-003, 4 p. (Also available at http://pubs.water.usgs.gov/fs-003-02.)

Moore, R.B., 2004, Quality of water in the fractured bedrock aquifer of New Hampshire: U.S. Geological Survey Scientific Investigations Report 2004-5093, 30 p. (Also available at http://pubs.usgs.gov/sir/2004/5093/.)

Moore, R.B., Johnston, C.M., Robinson, K.W., and Deacon, J.R., 2004, Estimation of total nitrogen and phosphorus in New England streams using spatially referenced regression models: U.S. Geological Survey Scientific Investigations Report 2004-5012, 42 p. (Also available at http://pubs.water.usgs.gov/sir2004-5012.)

Moran, M.J., Zogorski, J.S., and Squillace, P.J., 2005, MTBE and gasoline hydrocarbons in ground water of the United States: Ground Water, v. 43, no. 4, p. 615-627.

Mueller, D.K., and Titus, C.J., 2005, Quality of nutrient data from streams and ground water sampled during water years 1992-2001: U.S. Geological Survey Scientific Investigations Report 2005-5106, 27 p.

Mullaney, J.R., Lorenz, D.L., and Arntson, A.D., 2009, Chloride in groundwater and surface water in areas underlain by the glacial aquifer system, northern United States: U.S. Geological Survey Scientific Investigations Report 2009-5086, 41 p. 
Murray, J.J., ed., 1986, Appropriate use of fluorides for human health: Geneva, Switzerland, World Health Organization, 83 p. (Also available at http://whqlibdoc.who.int/ publications/1986/9241542039_(part1).pdf)

National Atmospheric Deposition Program, 2000, National Trends Network: Champaign, Ill., Illinois State Water Survey, available at http://nadp.sws.uiuc.edu/nadpdata.)

New Hampshire Department of Environmental Services, 1996, Road salt and water quality: New Hampshire Department of Services Environmental Fact Sheet WMB-4, 3 p. (Also available at http://des.nh.gov/organization/ commissioner/pip/factsheets/wmb/documents/wmb-4.pdf.)

New Hampshire Department of Environmental Services, 2007, Fluoride in drinking water: New Hampshire Water Supply and Engineering Bureau Environmental Fact Sheet WD-WSEB-3-5, 2 p. (Also available at http://des.nh.gov/ organization/commissioner/pip/factsheets/dwgb/documents/ dwgb-3-5.pdf.)

New Hampshire Department of Environmental Services, 2009, $\mathrm{M} t \mathrm{BE}$ in Drinking Water: New Hampshire Department of Environmental Services Environmental Fact Sheet WD-DWGB-3-19, 4 p. (accessed October 18, 2010, at http://des.nh.gov/organization/commissioner/pip/factsheets/ dwgb/documents/dwgb-3-19.pdf).

Nielsen, M.G., Lombard, P.J., and Schalk, L.F., 2010, Assessment of arsenic concentrations in domestic well water, by town, in Maine, 2005-09: U.S. Geological Survey Scientific Investigations Report 2010-5199, 68 p. (Also available at http://pubs.usgs.gov/sir/2010/5199.)

North, K.P., 2005, An evaluation of geologic controls on elevated naturally occurring radioactivity in bedrock ground water wells, northwest Vermont: Middlebury, Vt., Middlebury College, Department of Geology, unpublished senior thesis, accessed January 2010, at http://www.middlebury.edu/NR/rdonlyres/3A369E5CEDF2-437E-B39F-C34D75CD5218/0/North05Thesis.pdf.

Nuckols, J.R., Beane-Freeman, L.E., Lubin, J.H., Airola, M.S., Baris, Dalsu, and Ayotte, J.D., Taylor, Anne, Paulu, Chris, Karagas, M.R., Colt, Joanne, Ward, M.H., Huang, An-Tsun, Bress, William, Cherala, Sai, Silverman, D.T., and Cantor, K.P., 2011, Estimating water supply arsenic levels in the New England bladder cancer study: Environmental Health Perspectives, v. 119, no. 9.

Olcott, P.G., 1995, Ground water atlas of the United States, Connecticut, Maine, Massachusetts, New Hampshire, New York, Rhode Island, Vermont: U.S. Geological Survey Hydrologic Atlas HA-730-M, 1 map. (Also available at http://pubs.usgs.gov/ha/ha730/ch_m/index.html.)

Ollinger, S.V., Aber, J.D., Lovett, G.M., Millham, S.E., Lathrop, R.G., and Ellis, J.M., 1993, A spatial model of atmospheric deposition for the northeastern U.S.: Ecological Applications, v. 3, no. 3, p. 459-472.
Osberg, P.H., Hussey, A.M., and Boone, G.M., 1985, Bedrock geologic map of Maine: Maine Geological Survey, Department of Conservation, 1 map, scale 1:500,000.

Oze, Christopher, Bird, D.K., and Fendorf, Scott, 2007, Genesis of hexavalent chromium from natural sources in soil and groundwater: Proceedings of the National Academy of Sciences of the United States of America (PNAS), v. 104, no. 16, p. 6544-6549, accessed October 15, 2010, at http://www.pnas.org/ content/104/16/6544.full.pdf+html.

Panno, S.V., Hackley, K.C., Hwang, H.H., Greenberg, S., Krapac, I.G., Landsberger, S., and O'Kelly, D.J., 2005, Characterization and identification of $\mathrm{Na}-\mathrm{Cl}$ sources in ground water: Ground Water, v. 44, no. 2, p. 176-187. (Also available at http://www3.interscience.wiley.com/cgibin/fulltext/118626866/PDFSTART.)

Peckenham, J.M., 2002, The occurrence and persistence of MTBE in groundwater in Windham, Maine: New England Focus Conference on Groundwater Issues, October 3, 2002, 15 p. (Also available at http://water.usgs.gov/wrri/02grants/ prog-compl-reports/2002ME1B.pdf.)

Peters, S.C., 2008, Arsenic in groundwaters in the Northern Appalachian Mountain belt-A review of patterns and processes: Journal of Contaminant Hydrology, v. 99, p. 8-21.

Peters, S.C., and Blum, J.D., 2003, The source and transport of arsenic in a bedrock aquifer, New Hampshire, U.S.A.: Applied Geochemistry, v. 18, no. 11, p. 1773-1787.

Peters, S.C., Blum, J.D., Klaue, Bjoern, and Karagas, M.R., 1999, Arsenic occurrence in New Hampshire drinking water: Environmental Science and Technology, v. 33, no. 9, p. 1328-1333. (Also available at http://pubs.acs.org/ doi/pdf/10.1021/es980999e.)

Phillips, J.D., Duval, J.S., and Ambroziak, R.A., 1993, National geophysical data grids - Gamma-ray, gravity, magnetic, and topographic data for the conterminous United States: U.S. Geological Survey Digital Data Series DDS-9, accessed May 2005, at ftp://ftpext.usgs.gov/ pub/cr/co/denver/musette/pub/GEOPHYSICAL_DATA/ cdrom_DDS-9/

Pierce, H.A., Walsh, G.J., Burruss, R.C., and Degnan, J.R., 2007, Borehole characterization of a methane-yielding bedrock well, Tyngsborough, Massachusetts: U.S. Geological Survey Open-File Report 2007-1399, 1 DVD. (Also available at http://pubs.usgs.gov/of/2007/1399/.)

Plummer, L.N., and Busenberg, Eurybiades, 2000, Chlorofluorocarbons, in Cook, P.G., and Herczeg, A.L., eds., Environmental tracers in subsurface hydrology: Boston/Dordrecht/London, Kluwer Academic Publishers, p. 441-478. 
Plummer, L.N., Michel, R.L., Thurman, E.M., and Glynn, P.D., 1993, Environmental tracers for age-dating young ground water, in Alley, W.M., ed., Regional ground-water quality: New York, Van Nostrand Reinhold, p. 255-294.

Rafique, Tahir, Naseem, Shahid, Usmani-Haider, Tanzil, Bashir, Erum, Khan-Ahmed, Farooque, and Bhanger-Iqbal, Muhammad, 2009, Geochemical factors controlling the occurrence of high fluoride groundwater in the Nagar Parkar area, Sindh, Pakistan: Journal of Hazardous Materials, v. 171 , nos. 1-3, p. 424-430.

Robinson, G.R., Jr., 1997, Portraying chemical properties of bedrock for water quality and ecosystem analysis: An approach for the New England region: U.S. Geological Survey Open-File Report 97-154, 17 p.

Robinson, G.R., Jr., and Ayotte, J.D., 2006, The influence of geology and land use on arsenic in stream sediments and ground waters in New England, U.S.A.: Applied Geochemistry, v. 21, no. 9, p. 1482-1497.

Robinson, G.R., Jr., Ayotte, J.D., Montgomery, D.L., and DeSimone, L.A., 2002, Lithogeochemical character of near-surface bedrock in the New England coastal basins: U.S. Geological Survey Open-File Report 02-007, digital data set, accessed February 2010, at http://pubs.water.usgs.gov/ofr02-007.

Robinson, G.R., Jr., and Kapo, K.E., 2003, Generalized lithology and lithogeochemical character of near-surface bedrock in the New England region: U.S. Geological Survey Open-File Report 03-225, 60 p. (Also available at http://pubs.usgs.gov/of/2003/of03-225/.)

Robinson, K.W., Flanagan, S.M., Ayotte, J.D., Campo, K.W., Chalmers, Ann, Coles, J.F., and Cuffney, T.F., 2004, Water quality in the New England coastal basins, Maine, New Hampshire, Massachusetts, and Rhode Island, 1999-2001: U.S. Geological Survey Circular 1226, 38 p.

Rogers, R.J., 1989, Geochemical comparison of ground water in areas of New England, New York, and Pennsylvania: Ground Water, v. 27, no. 5, p. 690-712.

Rose, D.L., and Schroeder, M.P., 1995, Methods of analysis by the U.S. Geological Survey National Water Quality Laboratory-Determination of volatile organic compounds in water by purge and trap capillary gas chromatography/ mass spectrometry: U.S. Geological Survey Open-File Report 94-708, $26 \mathrm{p}$.

Rowe, B.L., Delzer, G.C., Bender, D.A., and Zogorski, J.S., 2005, Volatile organic compound matrix spike recoveries for ground- and surface-water samples, 1997-2001: U.S. Geological Survey Scientific Investigations Report 2005-5222, 64 p. (Also available at http://pubs.usgs.gov/ $\operatorname{sir} / 2005 / 5225 /)$
Ruddy, B.C., Lorenz, D.L., and Mueller, D.K., 2006, County level estimates of nutrient inputs to the land surface of the conterminous United States, 1982-2001: U.S. Geological Survey Scientific Investigations Report 2006-5012, 17 p. (Also available at http://pubs.usgs.gov/sir/2006/5012/pdf/ sir2006_5012.pdf.)

Scott, J.C., 1990, Computerized stratified random siteselection approaches for design of a ground-water-quality sampling network: U.S. Geological Survey WaterResources Investigations Report 90-4101, 109 p.

Snow, M.S., Kahl, J.S., Norton, S.A., and Olson, Christine, 1990, Geochemical determination of salinity sources in ground water wells in Maine: Proceedings, Focus Conference on Eastern Regional Ground Water Issues, Ground Water Management, no. 3, p. 313-327, accessed January 4, 2011, at https://info.ngwa.org/GWOL/ pdf/900156674.PDF)

Stober, Ingrid, and Bucher, Kurt, 1999, Origin of salinity of deep groundwater in crystalline rocks: Terra Nova, v. 11, no. 4, p. 181-185.

Szabo, Zoltan, DePaul, V.T., Kraemer, T.F., and Parsa, Bahman, 2005, Occurrence of radium-224 and comparison to that of radium-226 and radium-228 in water from the unconfined Kirkwood-Cohansey aquifer system, southern New Jersey: U.S. Geological Survey Scientific Investigations Report 2004-5224, 92 p.

Tepper, D.H., 1980, Hydrogeologic setting and geochemistry of residual periglacial Pleistocene seawater in wells in Maine: Orono, Maine, University of Maine, master's thesis, $126 \mathrm{p}$.

Toccalino, P.L., and Norman, J.E., 2006, Heath-based screening levels to evaluate U.S. Geological Survey ground water quality data: Risk Analysis, v. 26, no. 5, p. 13991348.

Toccalino, P.L., Norman, J.E., Booth, N.L., and Zogorski, J.S., 2008, Health-based screening levels-A tool for evaluating what water-quality data may mean to human health: U.S. Geological Survey, accessed December 15, 2010, at http://water.usgs.gov/nawqa/HBSL/.

Toran, L.E., and Saunders, J.A., 1999, Modeling alternative paths of chemical evolution of $\mathrm{Na}-\mathrm{HCO}_{3}$-type ground water near Oak Ridge, Tennessee, U.S.A.: Hydrogeology Journal, no. 7, p. 355-364, accessed October 15, 2010, at http://www.springerlink.com/content/n7y5p12q27nb92ey/.

U.S. Bureau of the Census 1990, Historical census of housing tables-Sources of water: U.S. Census Bureau, accessed October 14, 2009, at http://www.census.gov/hhes/www/ housing/census/historic/water.html.

U.S. Bureau of the Census, 2001, Population change and distribution, 1990 to 2000: U.S. Bureau of the Census 2000 Brief C2KBR/01-2, 7 p., accessed October 14, 2009, at http://www.census.gov/prod/2001pubs/c2kbr01-2.pdf. 
U.S. Environmental Protection Agency, 1980, Prescribed procedures for measurement of radioactivity in drinking water: U.S. Environmental Protection Agency EPA 600-480-032, August 1980, $133 \mathrm{p}$.

U.S. Environmental Protection Agency, 1997, Drinking water advisory - Consumer acceptability advice and health effects analysis on methyl tertiary-butyl ether (MtBE): U.S. Environmental Protection Agency, EPA-822-F-97-009. (Also available at http://www.epa.gov/waterscience/criteria/ drinking/mtbe.pdf.)

U.S. Environmental Protection Agency, 2009, Edition of the drinking water standards and health advisories: Washington, D.C., U.S. Environmental Protection Agency, EPA 816-F-09-0004, 18 p., accessed May 27, 2009, at http://www.epa.gov/safewater/consumer/pdf/mcl.pdf.

U.S. Geological Survey, variously dated, National field manual for the collection of water-quality data: U.S. Geological Survey Techniques of Water-Resources Investigations, book 9, chaps. A1-A9, accessed May 27, 2009, at http://pubs.water.usgs.gov/twri9A.

U.S. Geological Survey, 1999, The quality of our nation's waters, nutrients and pesticides: U.S. Geological Survey Circular 1225, $82 \mathrm{p}$.

U.S. Geological Survey, 2004, The national geochemical survey-Database and documentation: U.S. Geological Survey Open-File Report 2004-1001, [unpaginated].

U.S. Geological Survey, 2006, National land use dataset (NLCD) 2001: U.S. Geological Survey digital data, accessed January 16, 2007, at http://www.mrlc.gov/zones/ zones_info.asp.

Wanty, B., Rice, A., and Langmuir, P., 1990, Prediction of uranium adsorption by crystalline rocks - The key role of reactive surface area: Symposium P, Scientific Basis for Nuclear Waste Management XIV, Materials Research Society Proceedings, v. 212, abstract accessed February 17, 2010, at http://www.mrs.org/s_mrs/sec_subscribe.asp?CID= $12007 \& D I D=258409$ \&action $=$ detail.

Wathen, J.B., 1986, Factors affecting levels of Rn-222 in wells drilled in two mica granites in Maine and New Hampshire - Radon and ground water: Springfield, Ohio, Proceedings of the Third Annual Eastern Regional Ground Water Conference, p. 31-46.
Welch, A.H., Szabo, Zoltan, Parkhurst, D.L., van Metre, P.C., and Mullin, A.H., 1995, Gross-beta activity in groundwater: natural sources and artifacts of sampling and laboratory analysis: Applied Geochemistry, v. 10, p. 491-503.

Welch, A.H., Westjohn, D.B., Helsel, D.R., and Wanty, R.B., 2000, Arsenic in ground water of the United StatesOccurrence and geochemistry: Ground Water, v. 38, p. 589-604.

White, A.F., and Brantley, S.L., eds., 1995, Chemical weathering rates of silicate minerals: Washington, D.C., Mineralogical Society of America, accessed October 12, 2009, at http://www.emsei.psu.edu/ brantley/publications/ ChemicalWeathering1.pdf.

Wood, W.W., Kraemer, T.F., and Shapiro, Allen, 2004, Radon $\left({ }^{222} \mathrm{Rn}\right)$ in ground water of fractured rocks - A diffusion/ion exchange model: Ground Water, v. 42, no. 4, p. 552-567.

World Health Organization, 2004, Guidelines for drinkingwater quality ( $3 \mathrm{~d}$ ed.), v. 1 , Recommendations: Geneva, Switzerland, World Health Organization, 515 p.

Yang, Qiang, Jung, H.B., Culbertson, C.W., Marvinney, R.G., Loiselle, M.C., Lock, D.B., Cheek, Heidi, Thibodeau, Hilary, and Zheng, Yan, 2009, Spatial pattern of groundwater arsenic occurrence and association with bedrock geology in greater Augusta, Maine: Environmental Science and Technology, v. 43, p. 2714-2719.

Zapecza, O.S., and Szabo, Zoltan, 1986, National radioactivity in ground water-A review: U.S. Geological Survey WaterSupply Paper 2325, p. 50-57.

Zimmerman, M.J., Grady, S.J., Trench-Todd, E.C., Flanagan, S.M., and Nielsen, M.G., 1996, Water-quality assessment of the Connecticut, Housatonic, and Thames River Basins study unit-Analysis of available data on nutrients, suspended sediments, and pesticides, 1972-92: U.S. Geological Survey Water-Resources Investigations Report 95-4203, 162 p.

Zogorski, J.S., Carter, J.M., Ivahnenko, Tamara, Lapham, W.W., Moran, M.J., Rowe, B.L., Squillace, P.J., and Toccalino, P.L., 2006, Volatile organic compounds in the Nation's ground water and drinking-water supply wells: U.S. Geological Survey Circular 1292, 101 p. 


\section{Appendixes 1-11}

\section{Tables}

1-1. Summary statistics for selected physiochemical properties of, and inorganic waterquality constituents in water samples collected for the U.S. Geological Survey National Water-Quality Assessment Program from 88 domestic wells in crystalline rock aquifers in New England, 1995-2000.

2-1. Summary statistics for selected physiochemical properties of, and inorganic waterquality constituents in water samples collected for the U.S. Geological Survey National Water-Quality Assessment Program from 29 domestic wells in crystalline rock aquifers in New Jersey and New York, 1997.

3-1. Summary statistics for selected physiochemical properties and water-quality constituents in untreated water samples collected for the U.S. Environmental Protection Agency Safe Drinking Water Act Program from 4,664 public-supply wells in New England crystalline rock aquifers, 1997-2007

4-1. Rho and probability values from Spearman correlations of selected water-quality properties and constituents, and well construction properties with apparent residence time of groundwater from water samples collected for the U.S. Geological Survey National Water-Quality Assessment Program in domestic wells in New England crystalline rock aquifers, 1999-2000.

5-1. Rho and probability values from Spearman correlations of selected water-quality properties and constituents, land-use data, human population data, and well construction properties, with nitrate and chloride concentrations in water samples collected from domestic and public-supply wells in New England crystalline rock aquifers, 1995-2007

6-1. Highest five concentrations for selected water-quality constituents in water samples from domestic and public-supply wells in New England crystalline rock aquifers, 1995-2007.

7-1. Rho and probability values from Spearman correlations of selected water-quality properties and constituents, land-use and human population data, well construction properties, and National Uranium Resource Evaluation Program streambed-sediment data, with fluoride and arsenic concentrations in water samples collected from domestic and public-supply wells in New England crystalline rock aquifers, 1995-2007

8-1. Rho and probability values from Spearman correlations of selected water properties and constituents, land-use and human population data, well construction properties, National Uranium Resource Evaluation Program streambed-sediment data, and terrestrial gamma-ray emissions data with uranium concentrations and ${ }^{222}$ radon activities in water samples collected from domestic and public-supply wells in New England crystalline rock aquifers, 1995-2007...

9-1. Summary of pesticide concentrations in water samples collected for the U.S. Geological Survey National Water-Quality Assessment Program from domestic wells in New England crystalline rock aquifers in New England, New Jersey, and New York, 1995-2000.

10-1. Summary of volatile organic compound concentrations in water samples collected for the U.S. Geological Survey National Water-Quality Assessment Program from domestic wells in New England crystalline rock aquifers in New England, New Jersey, and New York, 1995-2000

11-1. Rho and probability values from Spearman correlations of selected water-quality properties and constituents, land-use and human population data, and well construction properties with chloroform and methyl tert-butyl ether concentrations in water samples collected from domestic and public-supply wells in New England crystalline rock aquifers, 1995-2007. 


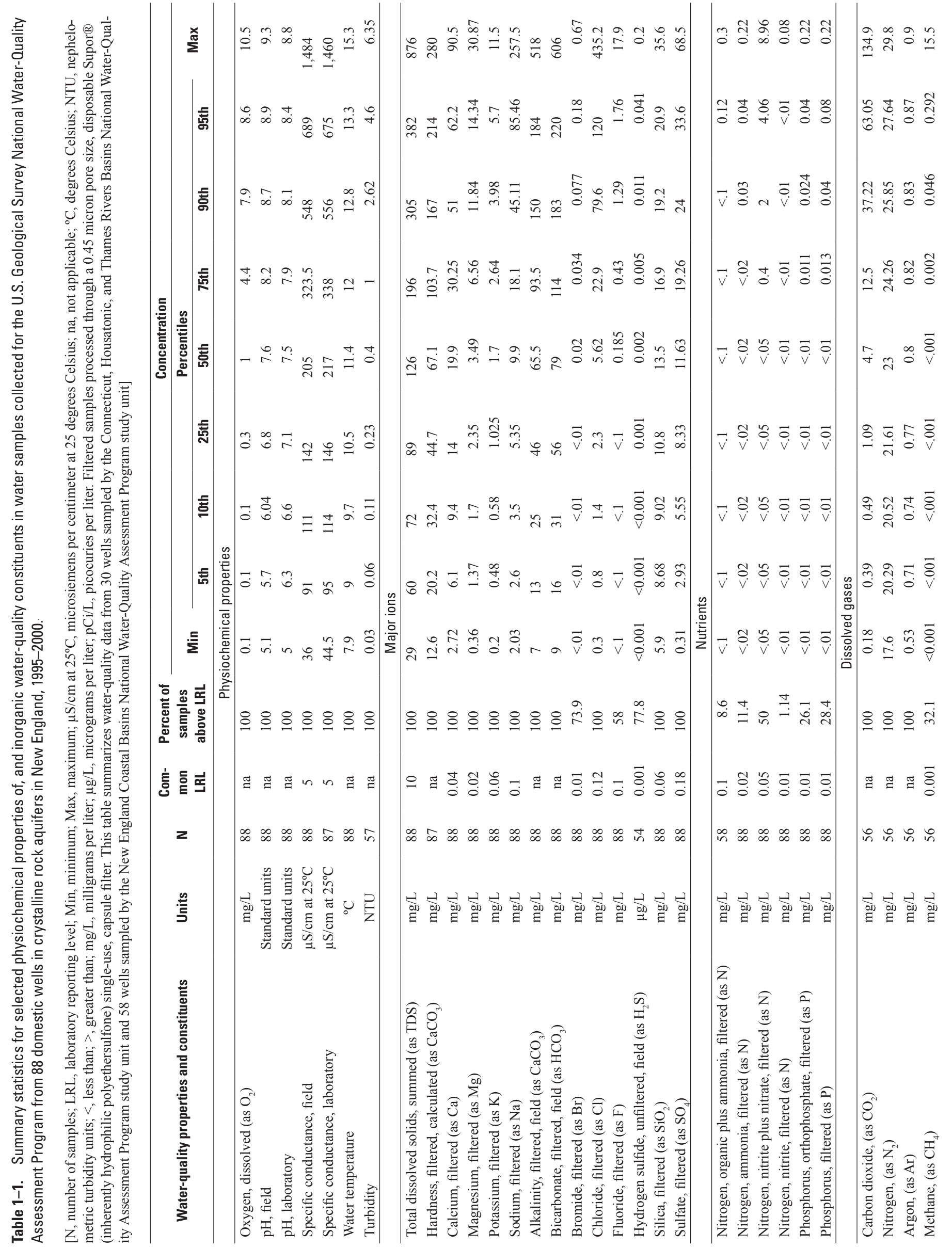


훙 윻

흘

过

7 :

is :

0.0

\&

bo

ن

نे है

泡

훈돈

을

$\dddot{\exists}$ 응

के

可

पु



证记

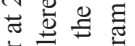

힐

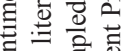

ड़े है

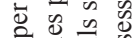

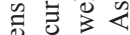

구욜

कै

当误苋

पे

is:

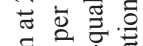

है पे

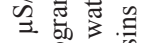

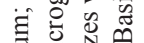

青

站署

$=$ के

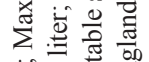

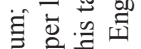

目范

影新

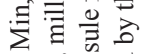

के 论

ठै

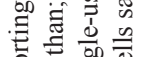

원호

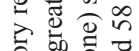

施

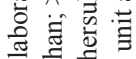

$\infty$ 의

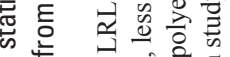

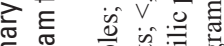

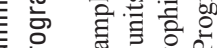

蛋竞节

흘을

局

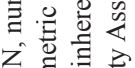

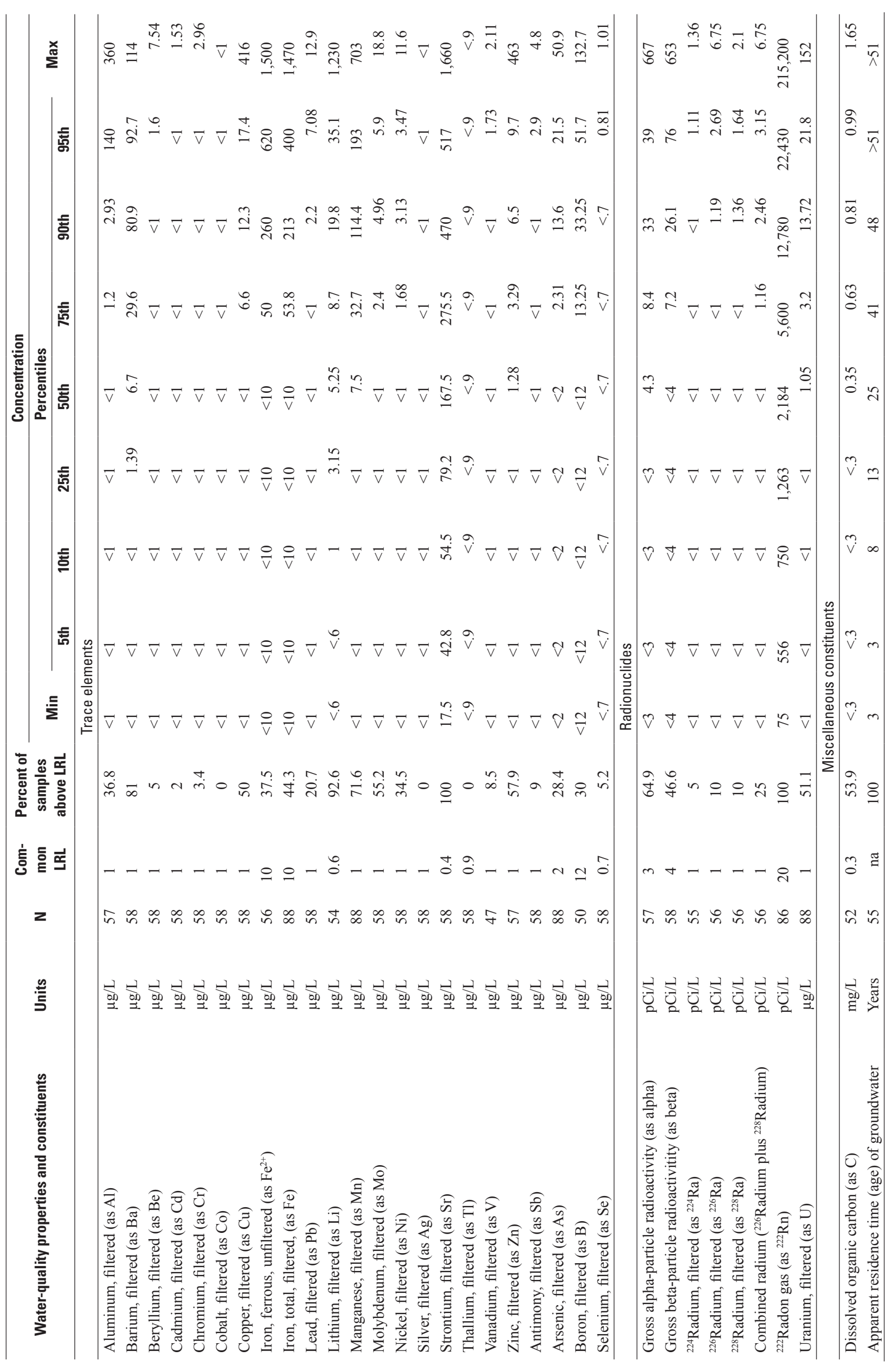




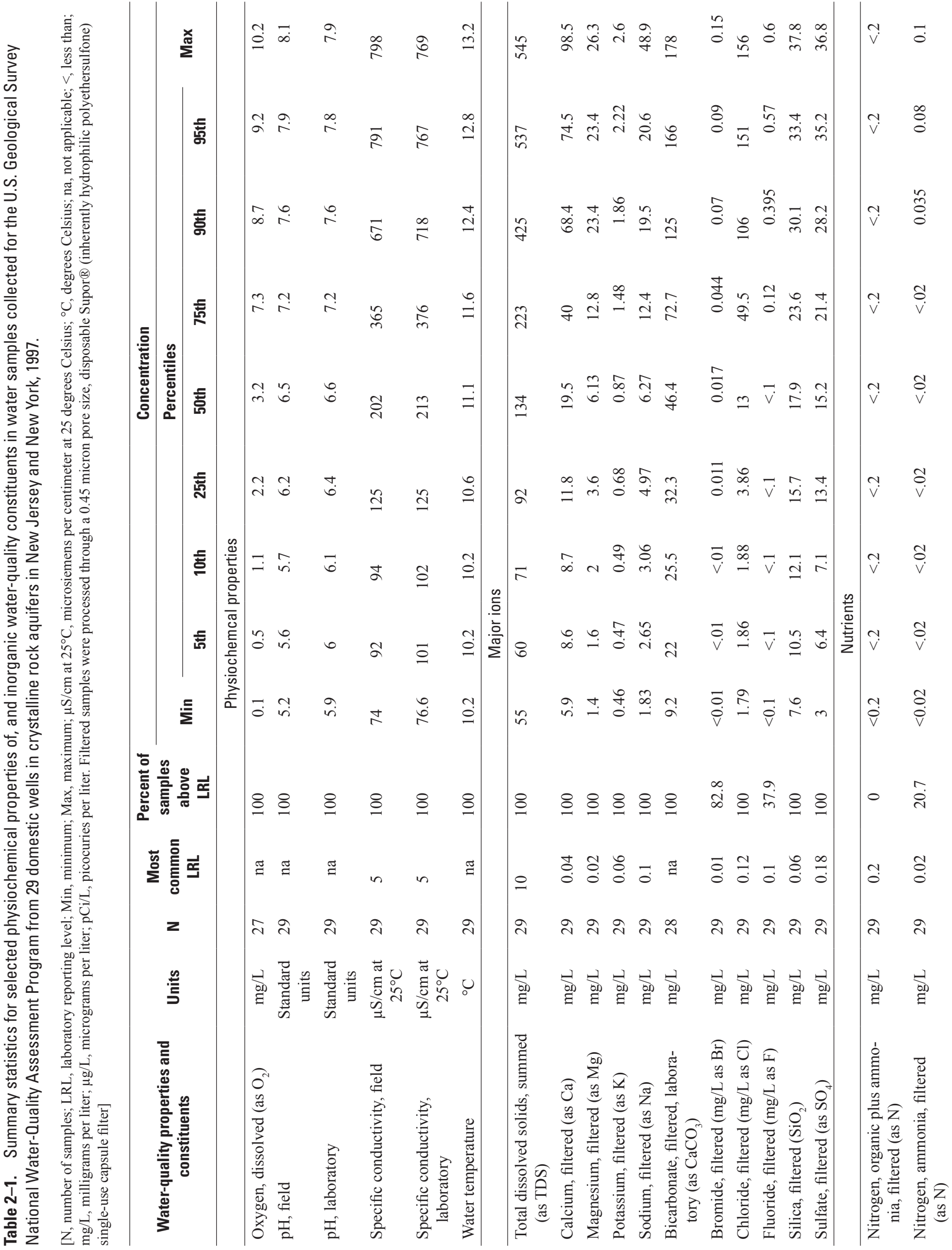




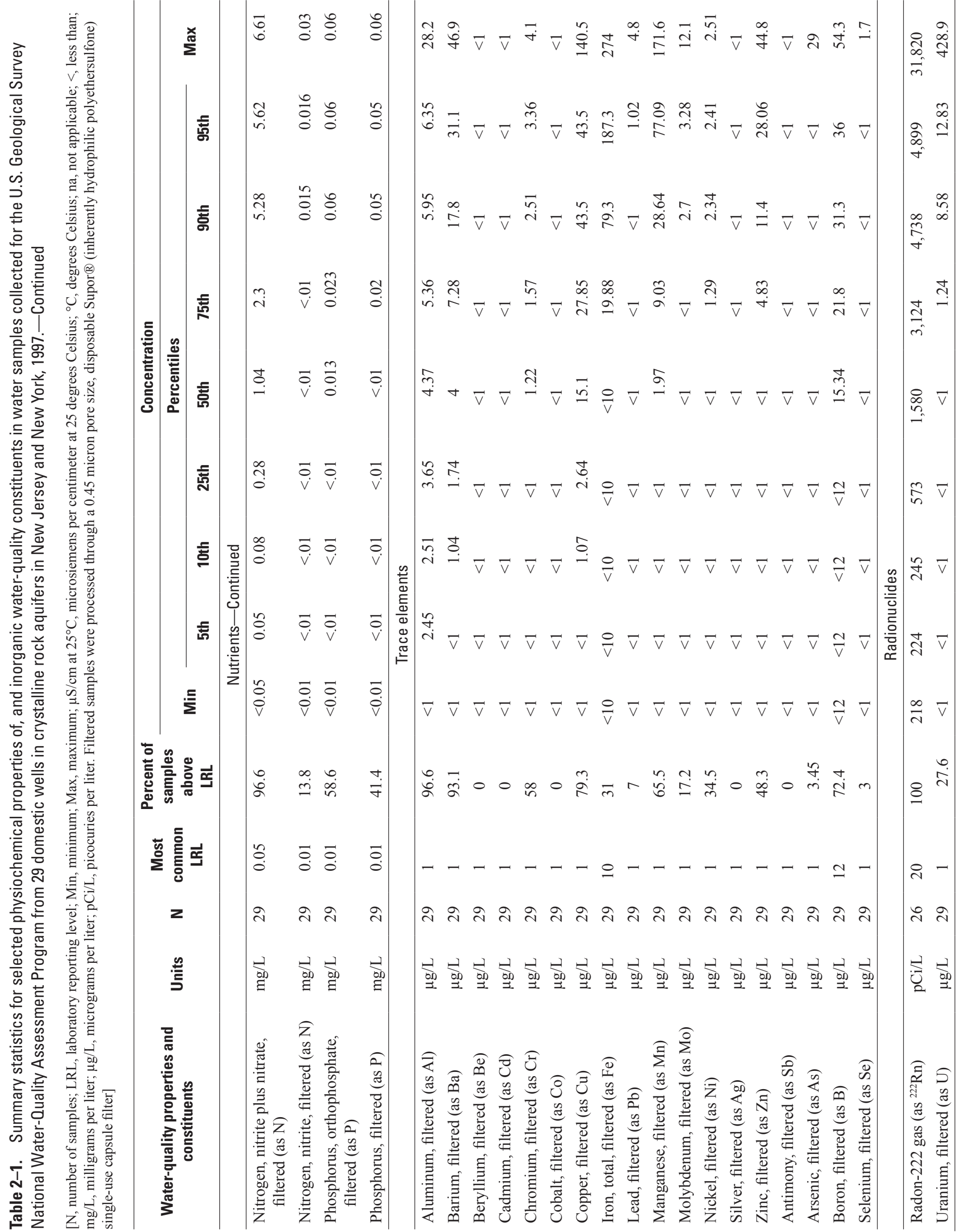




\begin{tabular}{|c|c|c|c|}
\hline 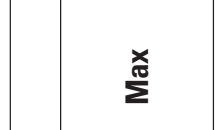 & $\simeq$ & : & 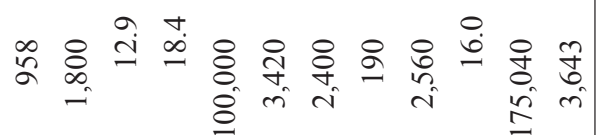 \\
\hline 䓌 & $\underset{\infty}{+}$ & $\stackrel{\circ}{\circ}$ & 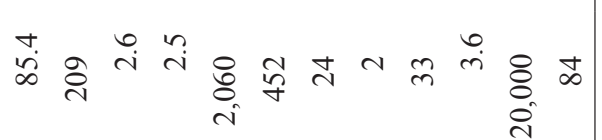 \\
\hline 善 & $\infty$ & $\overrightarrow{\mathrm{\sigma}}$ & 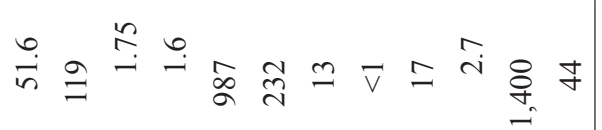 \\
\hline 言 & $\infty$ & S్ & 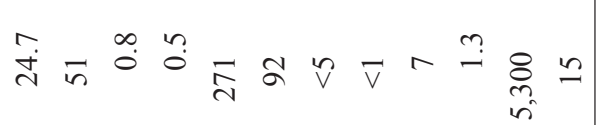 \\
\hline 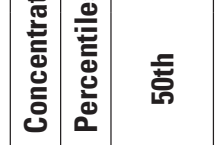 & $\stackrel{\circ}{i}$ & ì & 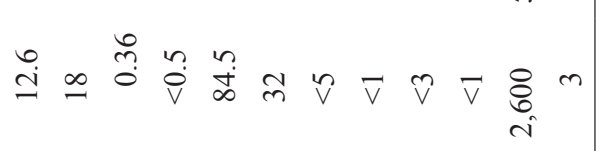 \\
\hline 䓌 & $\vec{r}$ & i & $\vec{\therefore} 0 \tilde{v}$ \\
\hline 言 & : & $\stackrel{\Xi}{\Xi}$ & $\because \operatorname{mos}$ \\
\hline 홈 & 3 & $\Xi$ & $m \stackrel{\infty}{i} \tilde{v}$ \\
\hline हE & in & ¿ & fon \\
\hline 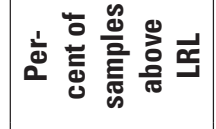 & 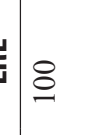 & 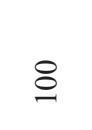 & \\
\hline 言豆至 & $\cong$ & $\Xi$ & \\
\hline$z$ & $\underset{\infty}{\infty}$ & $\stackrel{\mathbb{Z}}{\gtrless}$ & 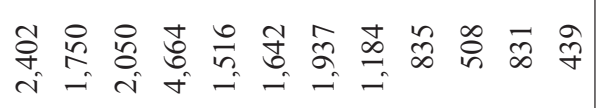 \\
\hline$\frac{2}{5}$ & & & \\
\hline 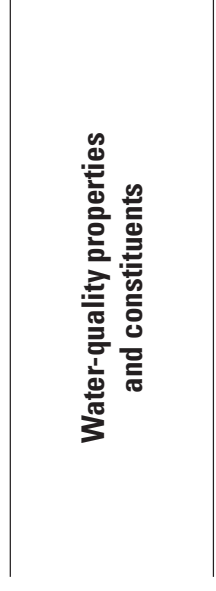 & 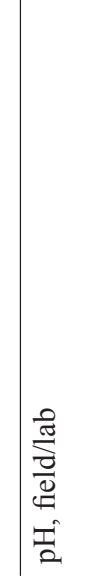 & 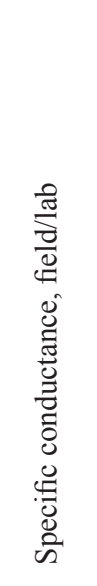 & 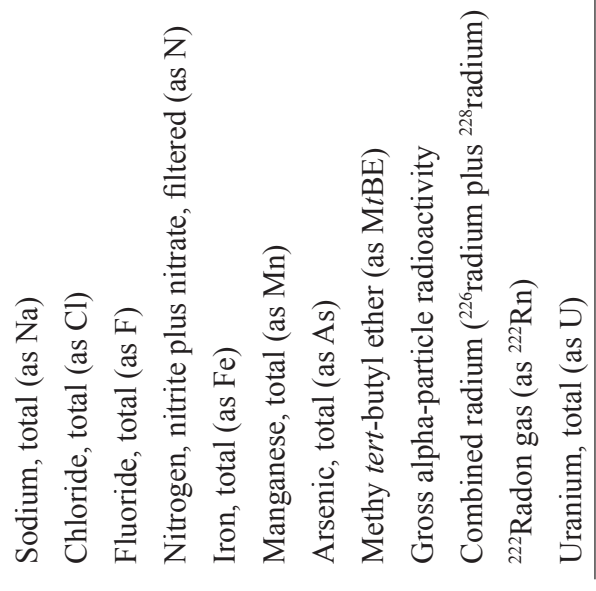 \\
\hline
\end{tabular}


Table 4-1. Rho and probability values from Spearman correlations of selected water-quality properties and constituents, and well construction properties with apparent residence time of groundwater from water samples collected for the U.S. Geological Survey National Water-Quality Assessment Program in domestic wells in New England crystalline rock aquifers, 1999-2000.

[The order of the correlation variable is from the highest correlation (either negative or positive) value to the lowest correlation value. Spearman's coefficients (rho) are considered significant when the $P$-values are less than or equal to 0.05 ; a negative rho value indicates an inverse relation. N, number of samples; (F), filtered sample; $<$, less than; $\mathrm{Na}: \mathrm{Cl}$, sodium to chloride; --, $P$-value not calculated]

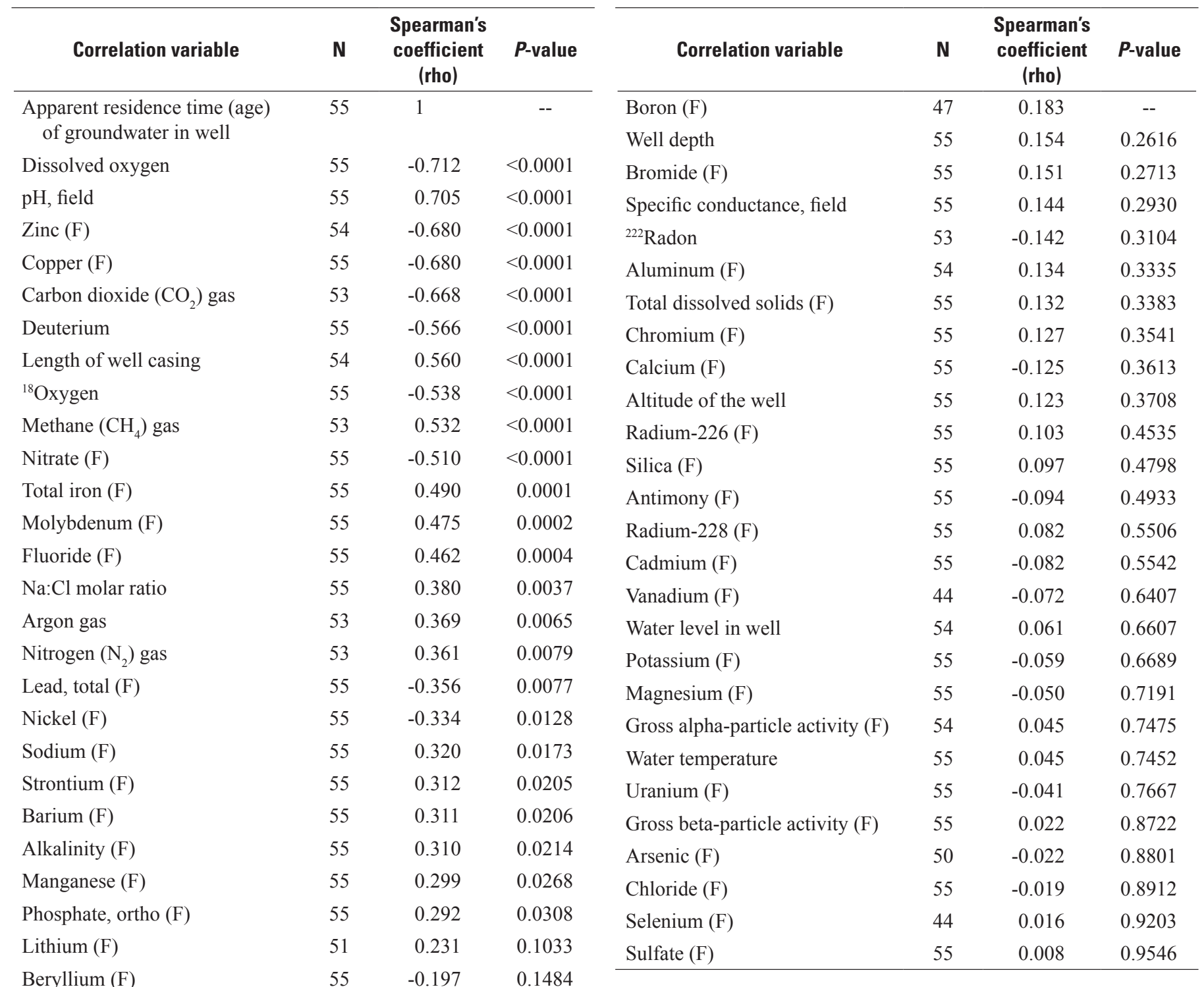


Table 5-1. Rho and probability values from Spearman correlations of selected water-quality properties and constituents, land-use data, human population data, and well construction properties, with nitrate and chloride concentrations in water samples collected from domestic and public-supply wells in New England crystalline rock aquifers, 1995-2007.

[Spearman's coefficients (rho) are considered significant (in bold) when the $P$-values are less than or equal to 0.05 ; a negative rho value indicates an inverse relation. Rho, Spearman's rho coefficient; $P$-value, Spearman's probability value; N, number of water samples; $<$, less than; $\mathrm{X}$, no data; --, $P$-value not calculated; persons $/ \mathrm{km}^{2}$, persons per square kilometer; USGS NAWQA, domestic bedrock wells sampled for the U.S. Geological Survey National Water-Quality Assessment Program in New England, New Jersey, and New York; USEPA SDWA, public-supply bedrock wells sampled for the U.S. Environmental Protection Agency Safe Drinking Water Act Program in New England]

\begin{tabular}{|c|c|c|c|c|c|c|c|}
\hline \multirow[b]{2}{*}{ Correlation variable } & \multirow{2}{*}{$\begin{array}{c}\text { Spearman's } \\
\text { correlation } \\
\text { variables }\end{array}$} & \multicolumn{3}{|c|}{ Nitrate } & \multicolumn{3}{|c|}{ Chloride } \\
\hline & & $\begin{array}{c}\text { USGS } \\
\text { NAWQA }\end{array}$ & $\begin{array}{l}\text { USEPA } \\
\text { SDWA }\end{array}$ & $\begin{array}{l}\text { All wells } \\
\text { in study }\end{array}$ & $\begin{array}{c}\text { USGS } \\
\text { NAWQA }\end{array}$ & $\begin{array}{l}\text { USEPA } \\
\text { SDWA }\end{array}$ & $\begin{array}{l}\text { All wells } \\
\text { in study }\end{array}$ \\
\hline \multicolumn{8}{|c|}{ Physiochemical properties and water-quality constituents determined from water samples } \\
\hline \multirow[t]{3}{*}{ Bicarbonate } & Rho & -0.19 & $\mathrm{X}$ & -0.19 & 0.176 & $\mathrm{X}$ & 0.176 \\
\hline & $P$-value & 0.0375 & $\mathrm{X}$ & 0.0412 & 0.0583 & $\mathrm{X}$ & 0.0583 \\
\hline & $\mathrm{N}$ & 116 & $\mathrm{X}$ & 116 & 116 & $\mathrm{X}$ & 116 \\
\hline \multirow[t]{3}{*}{ Arsenic } & Rho & -0.33 & -0.164 & -0.169 & 0.017 & 0.008 & 0.016 \\
\hline & $P$-value & 0.0003 & $<.0001$ & $<.0001$ & 0.8628 & 0.7692 & 0.5568 \\
\hline & $\mathrm{N}$ & 111 & 1,915 & 2,032 & 111 & 1,259 & 1,376 \\
\hline \multirow[t]{3}{*}{ Bromide } & Rho & 0.181 & $\mathrm{X}$ & 0.181 & 0.659 & $X$ & 0.659 \\
\hline & $P$-value & 0.0511 & $\mathrm{X}$ & 0.0512 & $<0.0001$ & $X$ & $<0.0001$ \\
\hline & $\mathrm{N}$ & 117 & $\mathrm{X}$ & 117 & 117 & $X$ & 117 \\
\hline \multirow[t]{3}{*}{ Calcium } & Rho & 0.295 & $\mathrm{X}$ & 0.295 & 0.48 & $\mathrm{X}$ & 0.4802 \\
\hline & $P$-value & 0.0012 & $\mathrm{X}$ & 0.0012 & $<0.0001$ & $X$ & $<0.0001$ \\
\hline & $\mathrm{N}$ & 117 & $\mathrm{X}$ & 117 & 117 & $X$ & 117 \\
\hline \multirow[t]{3}{*}{ Chloride } & Rho & 0.474 & 0.172 & 0.190 & 1 & 1 & 1 \\
\hline & $P$-value & $<.0001$ & $<.0001$ & $<.0001$ & -- & -- & -- \\
\hline & $\mathrm{N}$ & 117 & 1,737 & 1,854 & 117 & 1,750 & 1,867 \\
\hline \multirow[t]{3}{*}{ Dissolved oxgyen } & Rho & 0.602 & $\mathrm{X}$ & 0.602 & 0.106 & $X$ & 0.106 \\
\hline & $P$-value & $<0.0001$ & $\mathrm{X}$ & $<0.0001$ & 0.2608 & $X$ & 0.2608 \\
\hline & $\mathrm{N}$ & 115 & $\mathrm{X}$ & 115 & 115 & $\mathrm{X}$ & 115 \\
\hline \multirow[t]{3}{*}{ Fluoride } & Rho & -0.512 & -0.323 & -0.332 & -0.2 & -0.133 & -0.104 \\
\hline & $P$-value & $<.0001$ & $<.0001$ & $<.0001$ & 0.0302 & $<0.0001$ & $<0.0001$ \\
\hline & $\mathrm{N}$ & 117 & 2,040 & 2,157 & 117 & 1,396 & 1,513 \\
\hline \multirow[t]{3}{*}{ Iron, total } & Rho & -0.422 & -0.216 & -0.235 & 0.03 & 0.063 & 0.084 \\
\hline & $P$-value & $<.0001$ & $<.0001$ & $<.0001$ & 0.7521 & 0.0312 & 0.0025 \\
\hline & $\mathrm{N}$ & 117 & 1,503 & 1,620 & 117 & 1,160 & 1,277 \\
\hline \multirow[t]{3}{*}{ Magnesium } & Rho & 0.295 & $\mathrm{X}$ & 0.295 & 0.467 & $\mathrm{X}$ & 0.467 \\
\hline & $P$-value & 0.0012 & $\mathrm{X}$ & 0.0012 & $<0.001$ & $\mathrm{X}$ & $<0.0001$ \\
\hline & $\mathrm{N}$ & 117 & $\mathrm{X}$ & 117 & 117 & $\mathrm{X}$ & 117 \\
\hline \multirow[t]{3}{*}{ Manganese } & Rho & -0.361 & -0.247 & -0.255 & 0.045 & 0.121 & 0.137 \\
\hline & $P$-value & $<.0001$ & $<.0001$ & $<.0001$ & 0.6315 & $<0.0001$ & $<0.0001$ \\
\hline & $\mathrm{N}$ & 117 & 1,632 & 1,749 & 117 & 1,228 & 1,345 \\
\hline \multirow[t]{3}{*}{ Nitrate } & Rho & 1 & 1 & 1 & 0.474 & 0.172 & 0.19 \\
\hline & $P$-value & -- & -- & -- & $<0.0001$ & $<0.0001$ & $<0.0001$ \\
\hline & $\mathrm{N}$ & 117 & 4,664 & 4,781 & 117 & 1,737 & 1,854 \\
\hline \multirow[t]{3}{*}{$\mathrm{pH}$} & Rho & -0.587 & -0.296 & -0.312 & -0.209 & -0.179 & -0.17 \\
\hline & $P$-value & $<0.0001$ & $<0.0001$ & $<0.0001$ & 0.0236 & $<0.0001$ & $<0.0001$ \\
\hline & $\mathrm{N}$ & 117 & 1,883 & 2,000 & 117 & 1,522 & 1,639 \\
\hline
\end{tabular}


Table 5-1. Rho and probability values from Spearman correlations of selected water-quality properties and constituents, land-use data, human population data, and well construction properties, with nitrate and chloride concentrations in water samples collected from domestic and public-supply wells in New England crystalline rock aquifers, 1995-2007.-Continued

[Spearman's coefficients (rho) are considered significant (in bold) when the $P$-values are less than or equal to 0.05 ; a negative rho value indicates an inverse relation. Rho, Spearman's rho coefficient; $P$-value, Spearman's probability value; N, number of water samples; $<$, less than; $\mathrm{X}$, no data; --, $P$-value not calculated; persons $/ \mathrm{km}^{2}$, persons per square kilometer; USGS NAWQA, domestic bedrock wells sampled for the U.S. Geological Survey National Water-Quality Assessment Program in New England, New Jersey, and New York; USEPA SDWA, public-supply bedrock wells sampled for the U.S. Environmental Protection Agency Safe Drinking Water Act Program in New England]

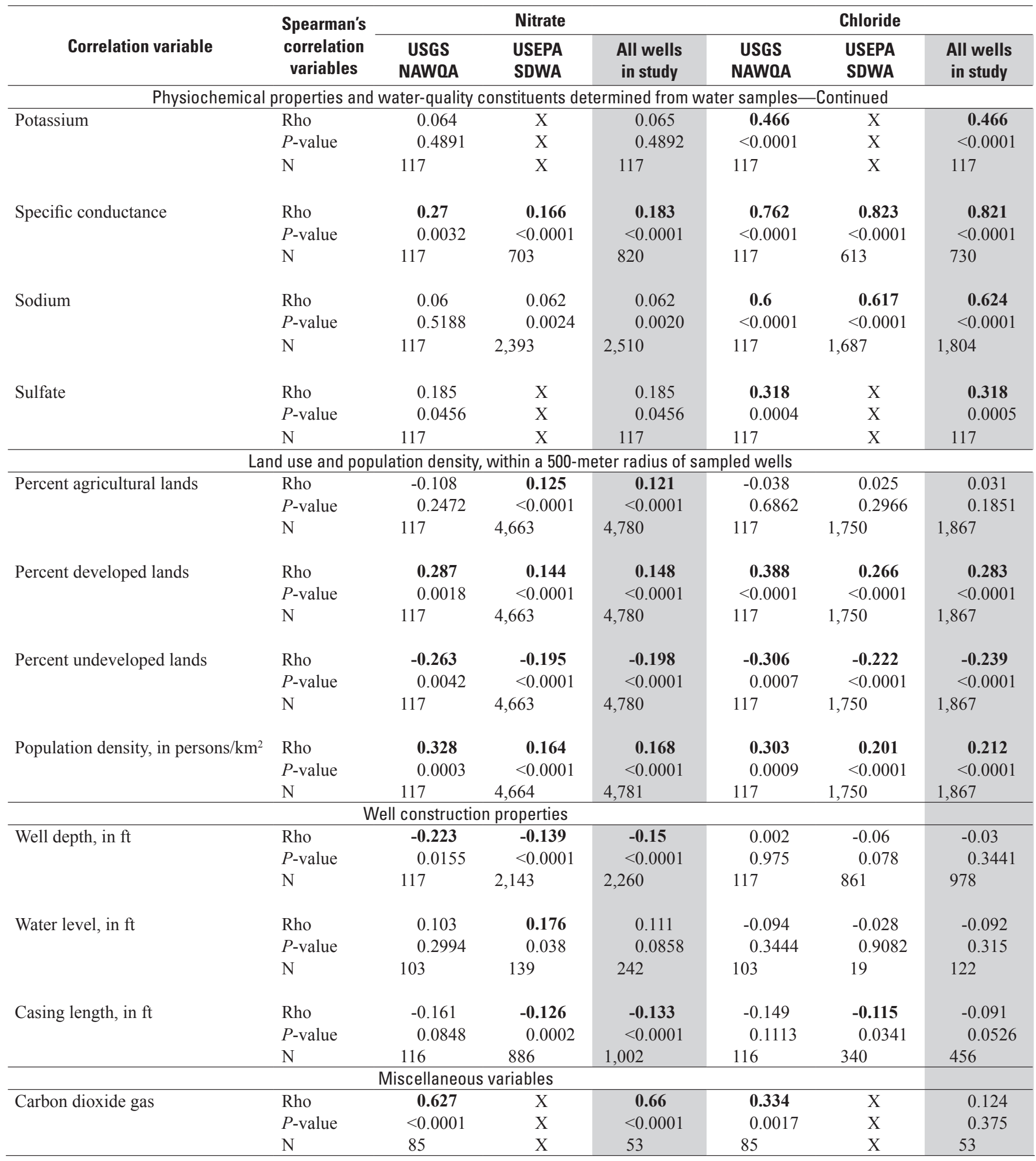


Table 6-1. Highest five concentrations for selected water-quality constituents in water samples from domestic and public-supply wells in New England crystalline rock aquifers, 1995-2007.

[n, number of water samples; Ag, agricultural land; Devel, developed or urban land; Undev, undeveloped land; $\mu \mathrm{g} / \mathrm{L}$, micrograms per liter; mg/L, milligrams per liter; $\mathrm{pCi} / \mathrm{L}$, picocuries per liter; $\mathrm{M}_{\mathrm{p}}$, pelitic rocks; $\mathrm{I}_{\mathrm{p}}$, peraluminous granite; $\mathrm{M}_{\mathrm{c}}-\mathrm{nm}$, calcareous metasedimentary rocks-NH-Maine geologic province; $\mathrm{I}_{\mathrm{m}}$, metaluminous granite; $\mathrm{M}_{\mathrm{ot}}$, metasedimentary rocks, other; $\mathrm{M}_{\mathrm{nb}}$, Narragansett Basin metasedimentary rocks; $\mathrm{CT}$, Connecticut; ME, Maine; $\mathrm{NH}, \mathrm{New}$ Hampshire; NJ, New Jersey; RI, Rhode Island; VT, Vermont; dom, domestic well sampled for the U.S. Geological Survey National Water-Quality Assessment Program; PS, public-supply well sampled for the U.S. Environmental Protection Agency Safe Drinking Water Act Program. Detailed information on State geologic map codes, geologic unit names, and their definitions can be found at http://nh.water.usgs.gov/projects/nawqa/lithogeo.htm or at http://tin.er.usgs.gov/geology/state/. In bold, rows with the two most common 'geologic unit names' in this table. The lithology groups are described in table 7 and are illustrated in figure 5B]

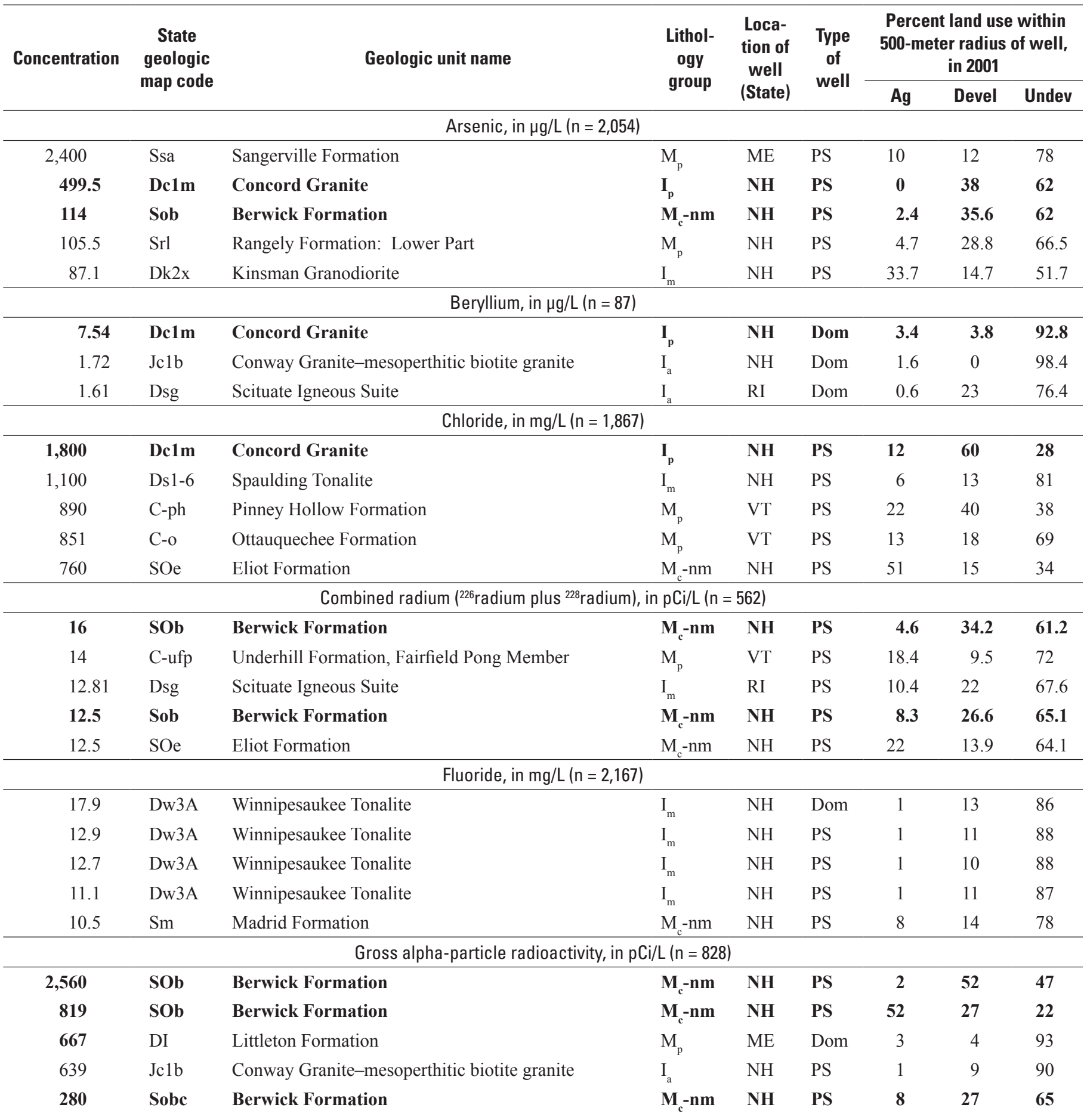


Table 6-1. Highest five concentrations for selected water-quality constituents in water samples from domestic and public-supply wells in New England crystalline rock aquifers, 1995-2007.-Continued

[n, number of water samples; Ag, agricultural land; Devel, developed or urban land; Undev, undeveloped land; $\mu \mathrm{g} / \mathrm{L}$, micrograms per liter; mg/L, milligrams per liter; $\mathrm{pCi} / \mathrm{L}$, picocuries per liter; $\mathrm{M}_{\mathrm{p}}$, pelitic rocks; $\mathrm{I}_{\mathrm{p}}$, peraluminous granite; $\mathrm{M}_{\mathrm{c}}-\mathrm{nm}$, calcareous metasedimentary rocks-NH-Maine geologic province; $\mathrm{I}_{\mathrm{m}}$, metaluminous granite; $\mathrm{M}_{\mathrm{ot}}$, metasedimentary rocks, other; $\mathrm{M}_{\mathrm{nb}}$, Narragansett Basin metasedimentary rocks; CT, Connecticut; ME, Maine; NH, New Hampshire; NJ, New Jersey; RI, Rhode Island; VT, Vermont; dom, domestic well sampled for the U.S. Geological Survey National Water-Quality Assessment Program; PS, public-supply well sampled for the U.S. Environmental Protection Agency Safe Drinking Water Act Program. Detailed information on State geologic map codes, geologic unit names, and their definitions can be found at http://nh.water.usgs.gov/projects/nawqa/lithogeo.htm or at http://tin.er.usgs.gov/geology/state/. In bold, rows with the two most common 'geologic unit names' in this table. The lithology groups are described in table 7 and are illustrated in figure 5B]

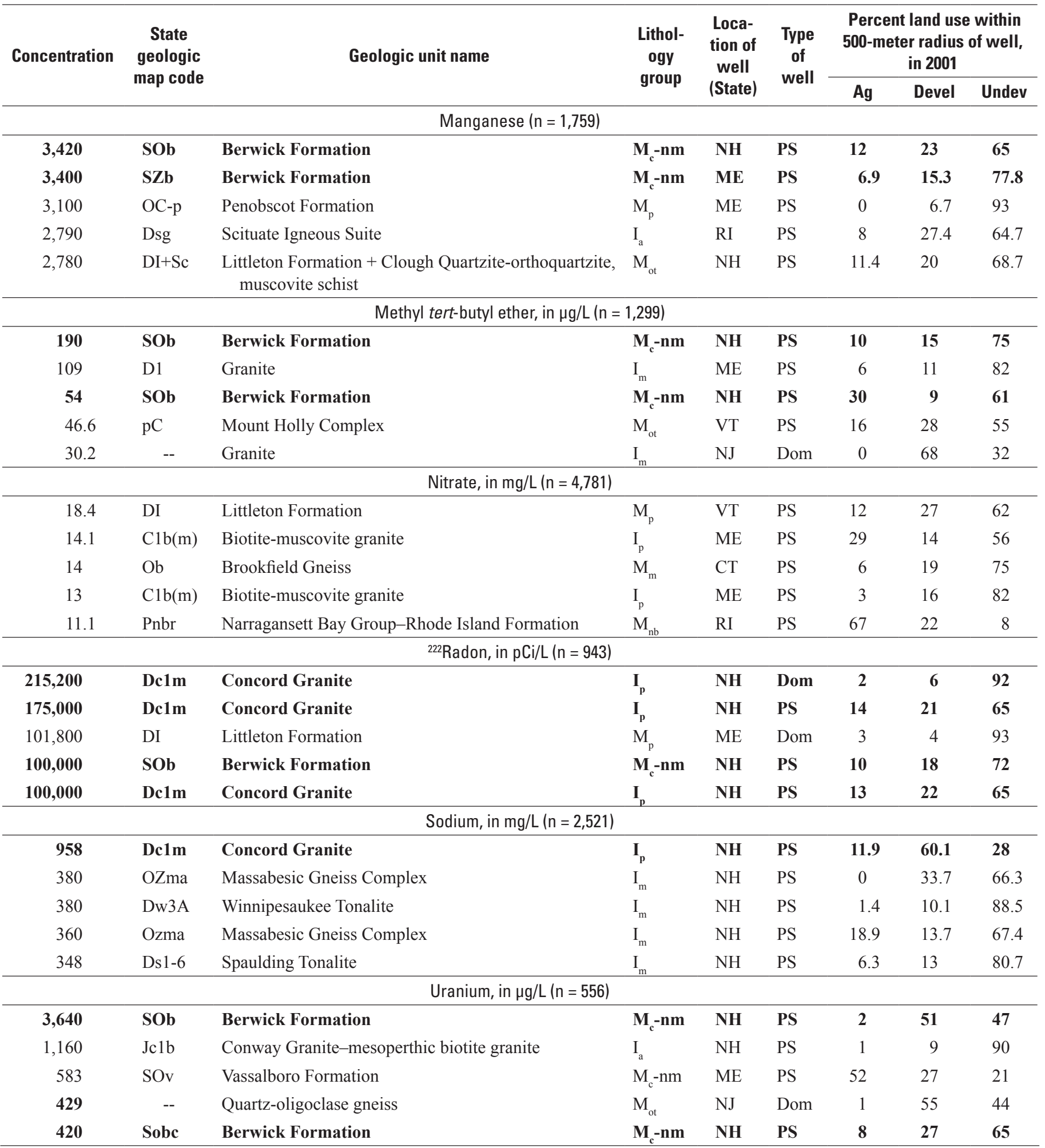


Table 7-1. Rho and probability values from Spearman correlations of selected water-quality properties and constituents, land-use and human population data, well construction properties, and National Uranium Resource Evaluation Program streambed-sediment data, with fluoride and arsenic concentrations in water samples collected from domestic and public-supply wells in New England crystalline rock aquifers, 1995-2007.

[Spearman's coefficients (rho) are considered significantly correlated (in bold) when the $P$-values are less than or equal to 0.05 ; a negative rho value indicates an inverse relation. Rho, Spearman's rho coefficient; $P$-value, Spearman's probability value; $\mathrm{N}$, number of water samples; $<$, less than; X, no data; --, $P$-value not calculated; na, did not perform correlation; persons $/ \mathrm{km}^{2}$, persons per square kilometer; $\mathrm{Fe}_{2} \mathrm{O}_{3}$, iron oxide; ppm, parts per million; USGS NAWQA, domestic bedrock wells sampled for the U.S. Geological Survey National Water-Quality Assessment Program in New England, New Jersey, and New York; USEPA SDWA, public-supply bedrock wells sampled for the U.S. Environmental Protection Agency Safe Drinking Water Act Program in New England]

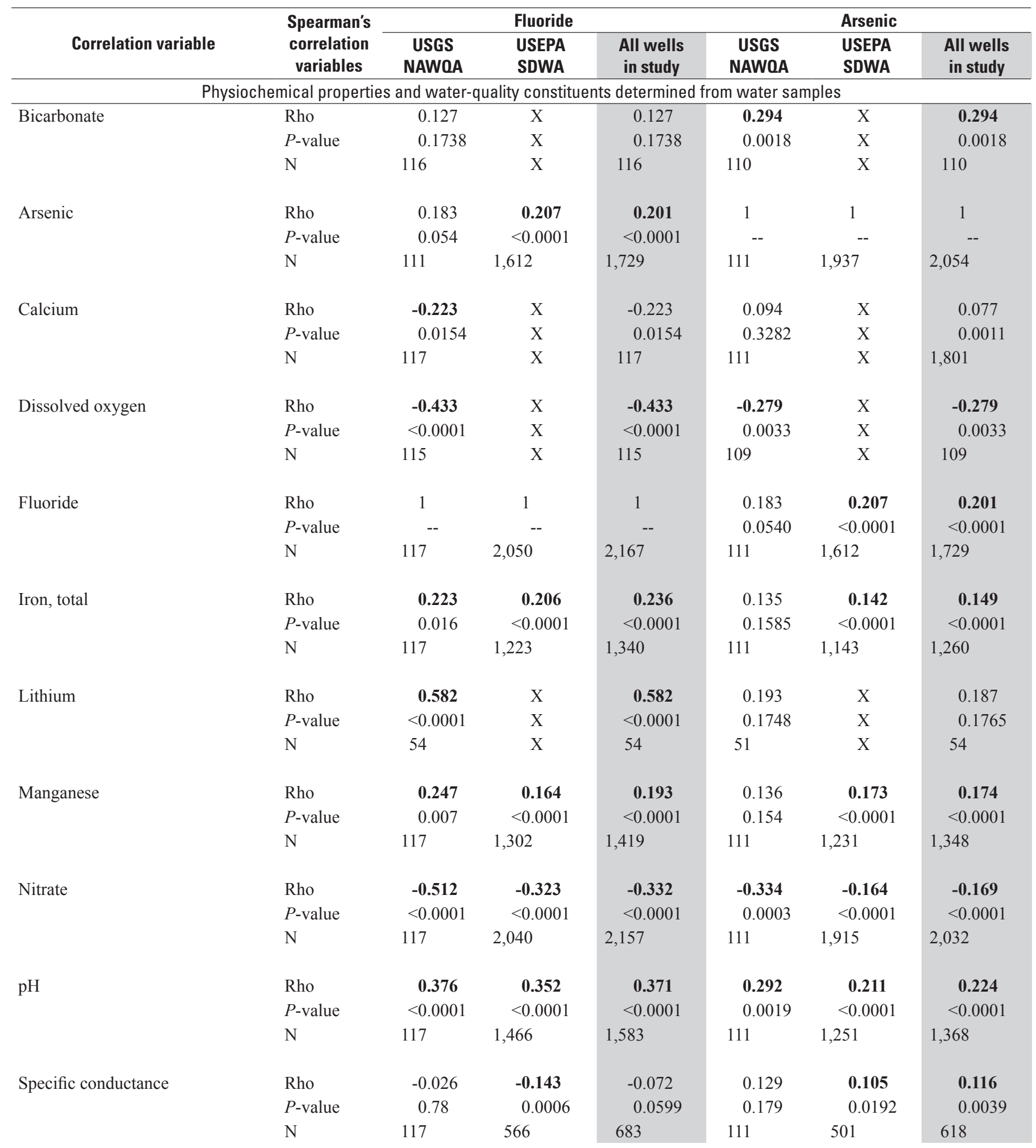


Table 7-1. Rho and probability values from Spearman correlations of selected water-quality properties and constituents, land-use and human population data, well construction properties, and National Uranium Resource Evaluation Program streambed-sediment data, with fluoride and arsenic concentrations in water samples collected from domestic and public-supply wells in New England crystalline rock aquifers, 1995-2007.-Continued

[Spearman's coefficients (rho) are considered significantly correlated (in bold) when the $P$-values are less than or equal to 0.05 ; a negative rho value indicates an inverse relation. Rho, Spearman's rho coefficient; $P$-value, Spearman's probability value; N, number of water samples; $<$, less than; X, no data; --, $P$-value not calculated; na, did not perform correlation; persons $/ \mathrm{km}^{2}$, persons per square kilometer; $\mathrm{Fe}_{2} \mathrm{O}_{3}$, iron oxide; ppm, parts per million; USGS NAWQA, domestic bedrock wells sampled for the U.S. Geological Survey National Water-Quality Assessment Program in New England, New Jersey, and New York; USEPA SDWA, public-supply bedrock wells sampled for the U.S. Environmental Protection Agency Safe Drinking Water Act Program in New England]

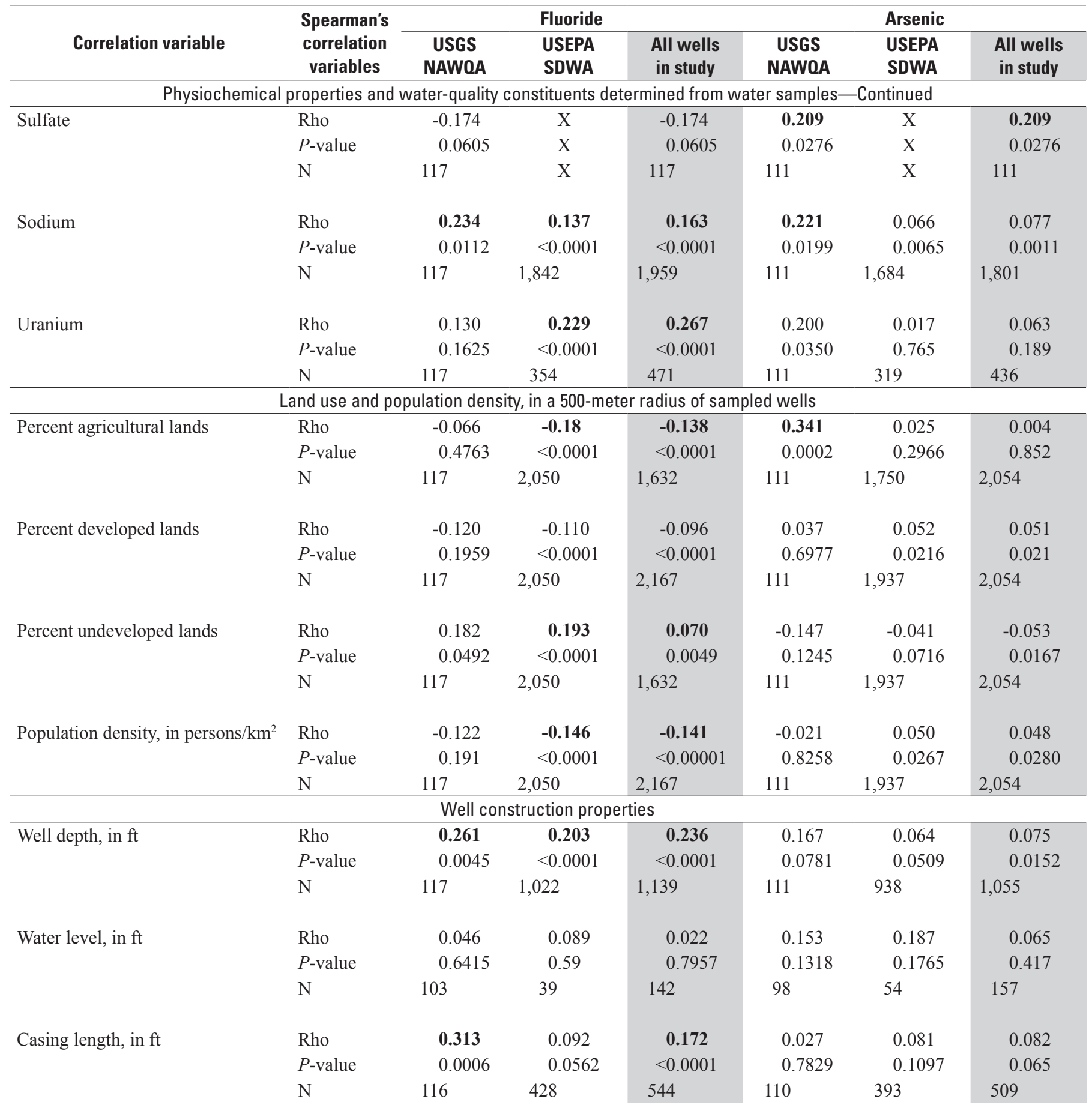


Table 7-1. Rho and probability values from Spearman correlations of selected water-quality properties and constituents, land-use and human population data, well construction properties, and National Uranium Resource Evaluation Program streambed-sediment data,with fluoride and arsenic concentrations in water samples collected from domestic and public-supply wells in New England crystalline rock aquifers, 1995-2007.-Continued

[Spearman's coefficients (rho) are considered significantly correlated (in bold) when the $P$-values are less than or equal to 0.05 ; a negative rho value indicates an inverse relation. Rho, Spearman's rho coefficient; $P$-value, Spearman's probability value; N, number of water samples; $<$, less than; X, no data; --, $P$-value not calculated; na, did not perform correlation; persons $/ \mathrm{km}^{2}$, persons per square kilometer; $\mathrm{Fe}_{2} \mathrm{O}_{3}$, iron oxide; ppm, parts per million; USGS NAWQA, domestic bedrock wells sampled for the U.S. Geological Survey National Water-Quality Assessment Program in New England, New Jersey, and New York; USEPA SDWA, public-supply bedrock wells sampled for the U.S. Environmental Protection Agency Safe Drinking Water Act Program in New England]

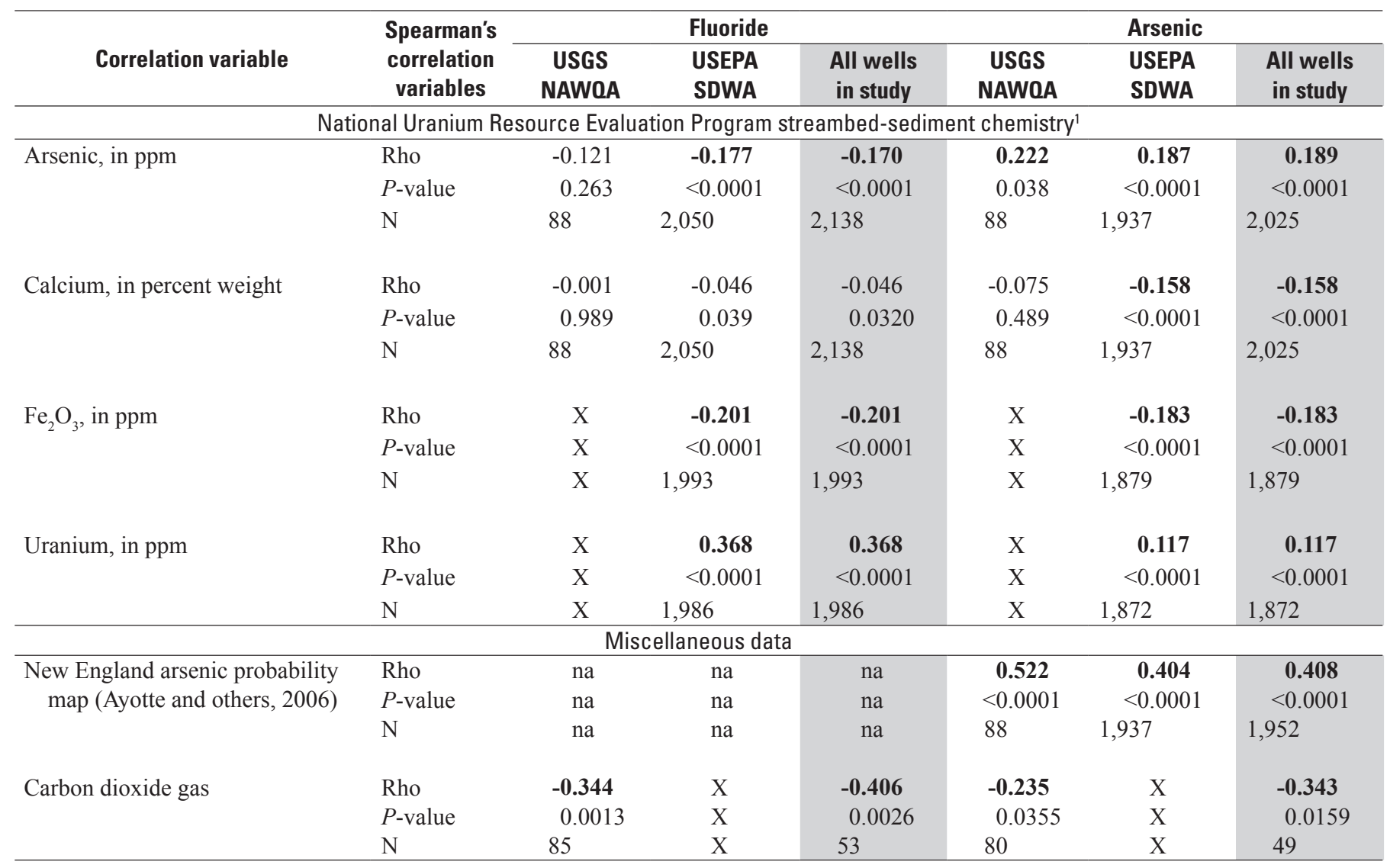

${ }^{1}$ These variables are geochemical data for the United States based primarily on streambed sediments and analyzed using a consistent set of methods as part of the USGS National Geochemical Survey (U.S. Geological Survey Open-File Report 2004-1001). Most of the original samples were collected as part of the U.S. Geological Survey National Uranium Resource Evaluation Program from 1975 to 1983 and re-analyzed (accessed May 2005, at http://tin.er.usgs.gov/ geochem/doc/home.htm).

\section{References Cited}

Ayotte, J.D., Nolan, B.T., Nuckols, J.R., Cantor, K.P., Robinson, G.R., Baris, D., Hayes, L., Karagas, M., Bress, W., Silverman, D.T., and Lubin, J.H., 2006, Modeling the probability of arsenic in groundwater in New England as a tool for exposure assessment: Environmental Science \& Technology, v. 40, no. 11 , p. $3578-3585$.

U.S. Geological Survey, 2004, The National Geochemical Survey—Database and Documentation: U.S. Geological Survey Open-File Report 2004-1001: Mineral Resources Online Spatial Data, accessed at http://tin.er.usgs.gov/geochem/doc/home.htm. 
Table 8-1. Rho and probability values from Spearman correlations of selected water properties and constituents, land-use and human population data, well construction properties, National Uranium Resource Evaluation Program streambed-sediment data, and terrestrial gamma-ray emissions data with uranium concentrations and ${ }^{222}$ radon activities in water samples collected from domestic and public-supply wells in New England crystalline rock aquifers, 1995-2007.

[Spearman's coefficients (rho) are considered significant (in bold) when the $P$-values are equal to or less than 0.05 ; a negative rho value indicates an inverse relation. Rho, Spearman's rho coefficient; $P$-value, Spearman's probability value; N, number of samples; $<$, less than; $\mathrm{X}$, no data; $\mathrm{Fe}_{2} \mathrm{O}_{3}$, iron oxide; ppm, parts per million; USGS NAWQA, domestic bedrock wells sampled for the U.S. Geological Survey National Water-Quality Assessment Program in New England, New Jersey, and New York; USEPA SDWA, public-supply bedrock wells sampled for the U.S. Environmental Protection Agency Safe Drinking Water Act Program in New England]

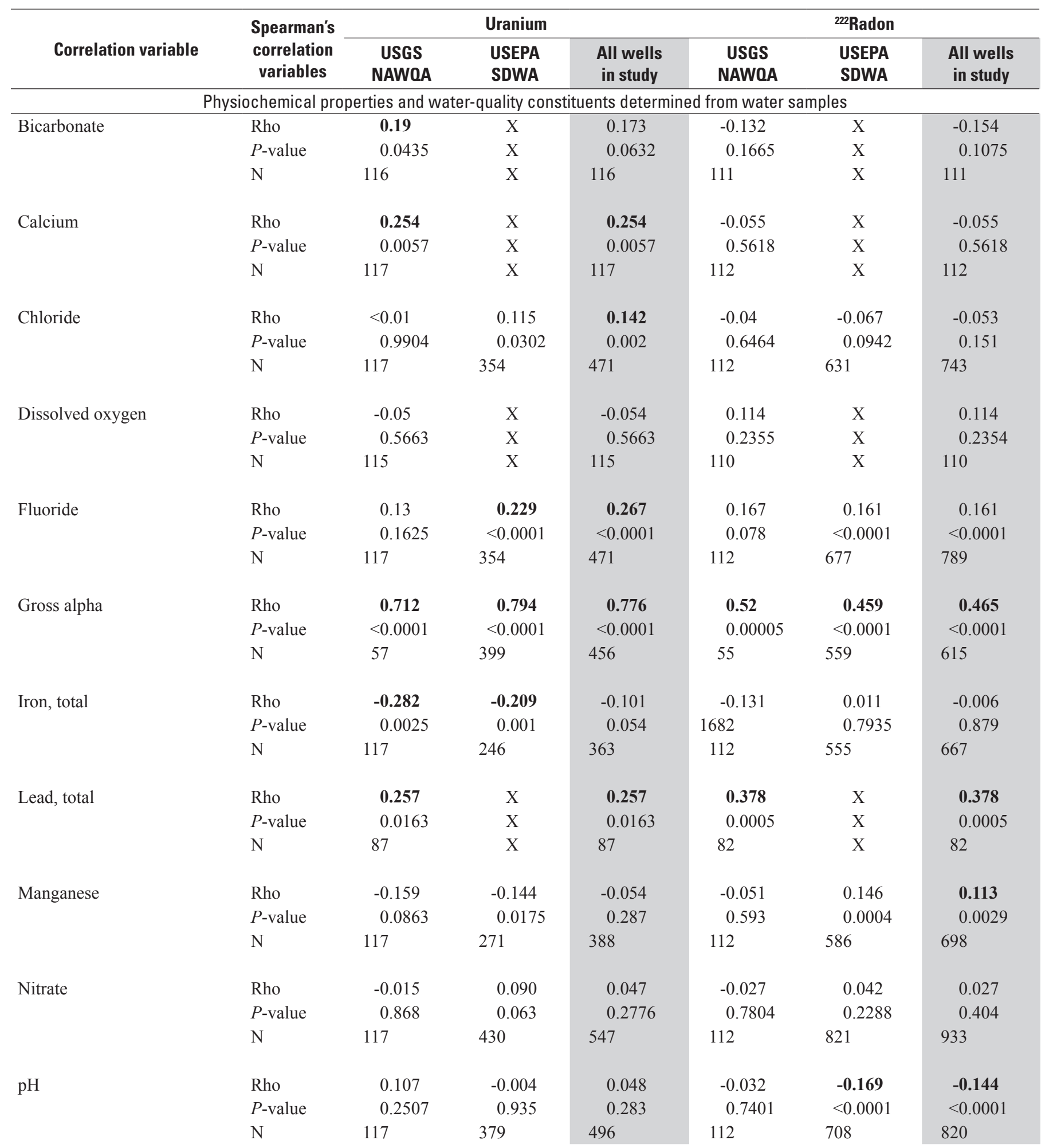


Table 8-1. Rho and probability values from Spearman correlations of selected water properties and constituents, land-use and human population data, well construction properties, National Uranium Resource Evaluation Program streambed-sediment data, and terrestrial gamma-ray emissions data with uranium concentrations and ${ }^{222}$ radon activities in water samples collected from domestic and public-supply wells in New England crystalline rock aquifers, 1995-2007.-Continued

[Spearman's coefficients (rho) are considered significant (in bold) when the $P$-values are equal to or less than 0.05 ; a negative rho value indicates an inverse relation. Rho, Spearman's rho coefficient; $P$-value, Spearman's probability value; $\mathrm{N}$, number of samples; $<$, less than; $\mathrm{X}$, no data; $\mathrm{Fe}_{2} \mathrm{O}_{3}$, iron oxide; ppm, parts per million; USGS NAWQA, domestic bedrock wells sampled for the U.S. Geological Survey National Water-Quality Assessment Program in New England, New Jersey, and New York; USEPA SDWA, public-supply bedrock wells sampled for the U.S. Environmental Protection Agency Safe Drinking Water Act Program in New England]

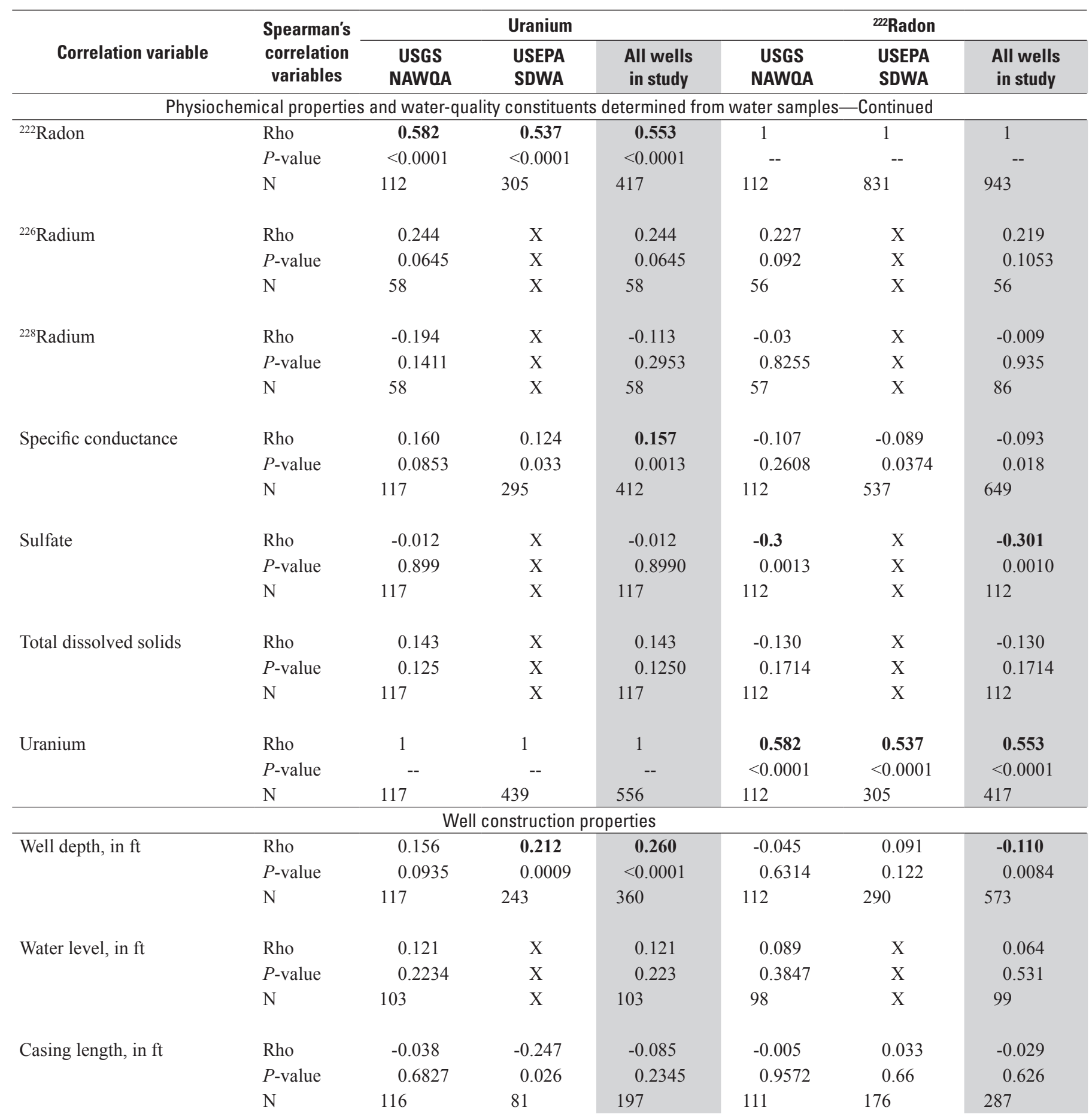


Table 8-1. Rho and probability values from Spearman correlations of selected water properties and constituents, land-use and human population data, well construction properties, National Uranium Resource Evaluation Program streambed-sediment data, and terrestrial gamma-ray emissions data with uranium concentrations and ${ }^{222}$ radon activities in water samples collected from domestic and public-supply wells in New England crystalline rock aquifers, 1995-2007.-Continued

[Spearman's coefficients (rho) are considered significant (in bold) when the $P$-values are equal to or less than 0.05 ; a negative rho value indicates an inverse relation. Rho, Spearman's rho coefficient; $P$-value, Spearman's probability value; N, number of samples; <, less than; $\mathrm{X}$, no data; $\mathrm{Fe}_{2} \mathrm{O}_{3}$, iron oxide; ppm, parts per million; USGS NAWQA, domestic bedrock wells sampled for the U.S. Geological Survey National Water-Quality Assessment Program in New England, New Jersey, and New York; USEPA SDWA, public-supply bedrock wells sampled for the U.S. Environmental Protection Agency Safe Drinking Water Act Program in New England]

\begin{tabular}{|c|c|c|c|c|c|c|c|}
\hline \multirow[b]{2}{*}{ Correlation variable } & \multirow{2}{*}{$\begin{array}{c}\text { Spearman's } \\
\text { correlation } \\
\text { variables }\end{array}$} & \multicolumn{3}{|c|}{ Uranium } & \multicolumn{3}{|c|}{ 222Radon } \\
\hline & & $\begin{array}{l}\text { USGS } \\
\text { NAWOA }\end{array}$ & $\begin{array}{l}\text { USEPA } \\
\text { SDWA }\end{array}$ & $\begin{array}{l}\text { All wells } \\
\text { in study }\end{array}$ & $\begin{array}{l}\text { USGS } \\
\text { NAWOA }\end{array}$ & $\begin{array}{l}\text { USEPA } \\
\text { SDWA }\end{array}$ & $\begin{array}{l}\text { All wells } \\
\text { in study }\end{array}$ \\
\hline \multirow[t]{3}{*}{ Calcium, in percent weight } & Rho & 0.033 & -0.194 & -0.157 & 0.045 & -0.083 & -0.069 \\
\hline & $P$-value & 0.7580 & $<0.0001$ & 0.0003 & 0.6825 & 0.0164 & 0.0355 \\
\hline & $\mathrm{N}$ & 88 & 439 & 527 & 86 & 831 & 917 \\
\hline \multirow{3}{*}{$\mathrm{Fe}_{2} \mathrm{O}_{3}$, in ppm } & Rho & $X$ & -0.312 & -0.312 & $X$ & -0.288 & -0.288 \\
\hline & $P$-value & $X$ & $<0.0001$ & $<0.0001$ & $X$ & $<0.0001$ & $<0.0001$ \\
\hline & $\mathrm{N}$ & $\mathrm{X}$ & 363 & 363 & $\mathrm{X}$ & 822 & 822 \\
\hline Uranium, in ppm & Rho & 0.156 & 0.205 & 0.205 & 0.11 & 0.166 & 0.165 \\
\hline \multirow{2}{*}{$\begin{array}{l}{ }^{232} \text { Thorium, in ppm equivalent } \\
\text { TH (eTH) }\end{array}$} & $P$-value & 0.1796 & 0.04 & 0.0002 & 0.075 & 0.0008 & $<0.0001$ \\
\hline & $\mathrm{N}$ & 88 & 415 & 528 & 82 & 788 & 896 \\
\hline \multirow[t]{3}{*}{${ }^{238}$ Uranium, in ppm U } & Rho & 0.213 & 0.200 & 0.187 & 0.216 & 0.202 & 0.190 \\
\hline & $P$-value & 0.052 & $<0.0001$ & $<0.0001$ & 0.052 & $<0.0001$ & $<0.0001$ \\
\hline & $\mathrm{N}$ & 84 & 415 & 528 & 82 & 788 & 896 \\
\hline
\end{tabular}

${ }^{1}$ These variables consist of geochemical data for the United States based primarily on streambed sediments and analyzed for using a consistent set of methods as part of the USGS National Geochemical Survey (U.S. Geological Survey Open-File Report 2004-1001). Most of the original samples were collected as part of the U.S. Geological Survey National Uranium Resource Evaluation Program from 1975 to 1983 and re-analyzed (accessed May 2005 at http:/tin.er.usgs.gov/geochem/doc/home.htm). Gamma-ray emissions data documented in Phillips and others, 1993.

${ }^{2}$ These variables consist of terrestrial gamma-ray emissions of near-surface sediments and are documented in Phillips and others, 1993.

\section{References Cited}

Phillips, J.D., Duval, J.S., and Ambroziak, R.A., 1993, National Geophysical Data Grids: Gamma-ray, gravity, magnetic, and topographic data for the conterminous United States: U.S. Geological Survey Digital Data Series DDS-9, accessed May 2005, at ftp://ftpext.usgs.gov/pub/cr/co/ denver/musette/pub/GEOPHYSICAL_DATA/cdrom_DDS-9/.

U.S. Geological Survey, 2004, The National Geochemical Survey-Database and Documentation: U.S. Geological Survey Open-File Report 2004-1001: Mineral resources online spatial data, online at http://tin.er.usgs.gov/geochem/doc/home.htm. 


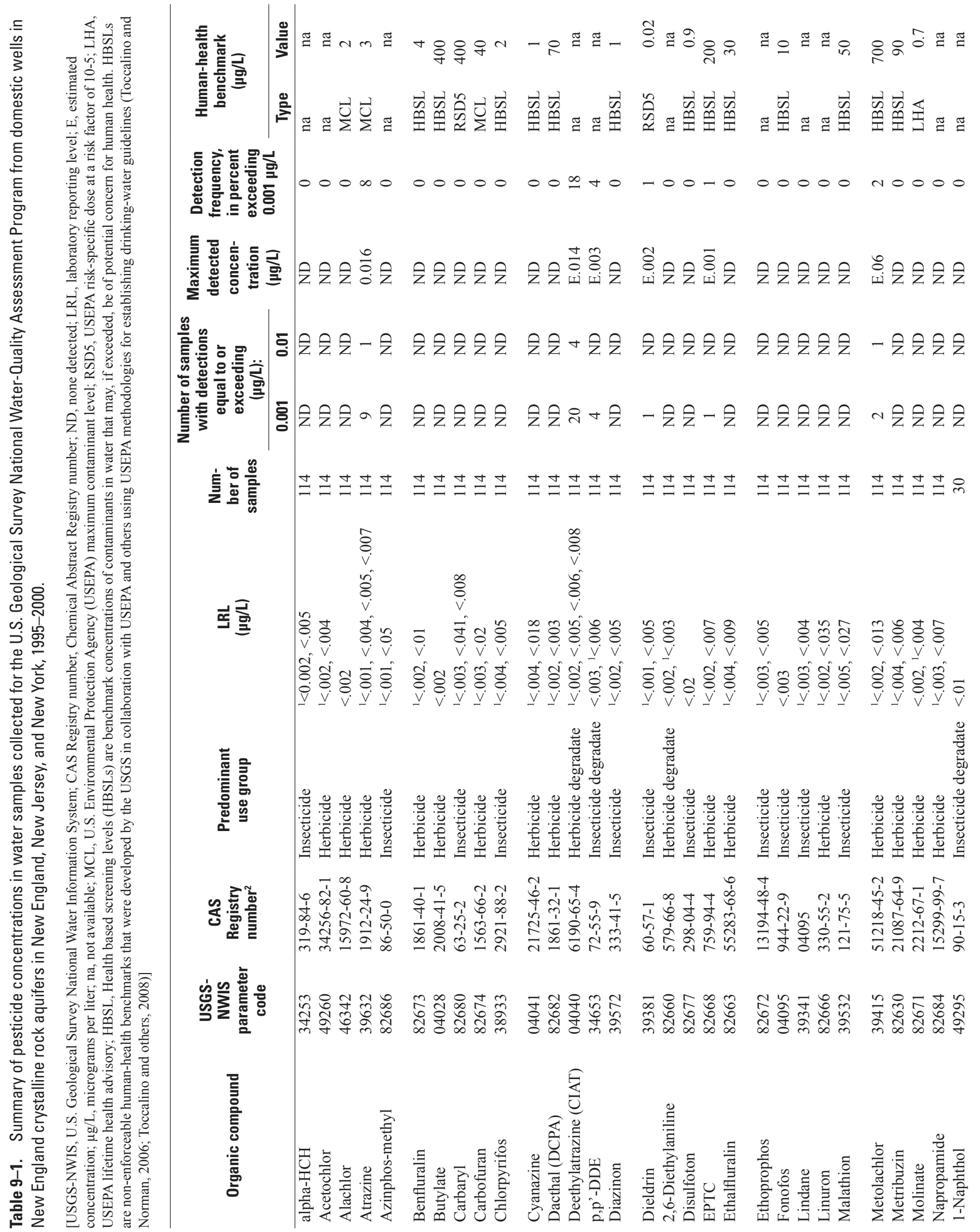




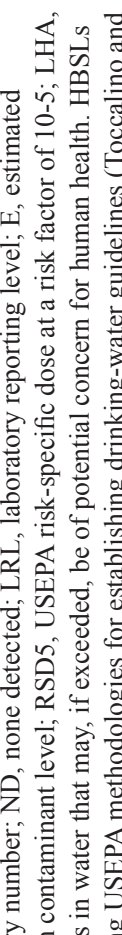

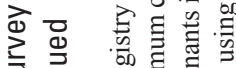

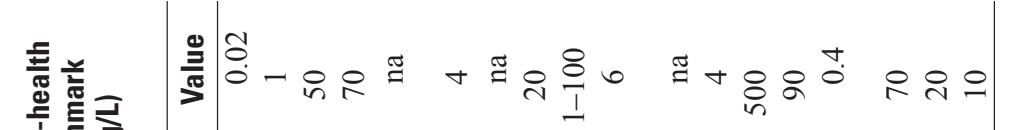
寡突

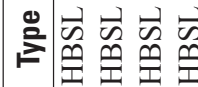

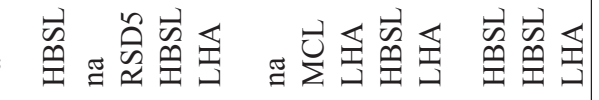

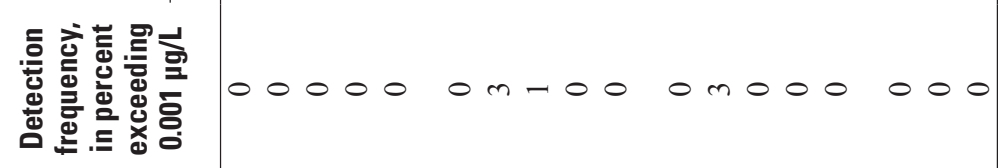

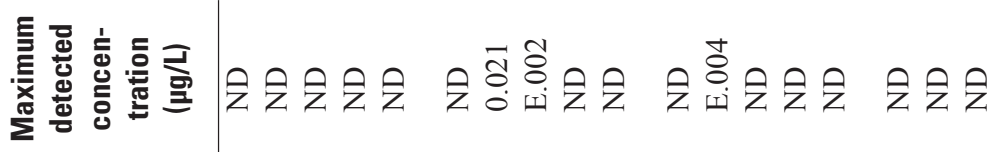

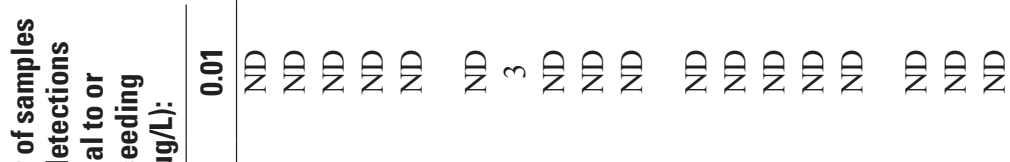

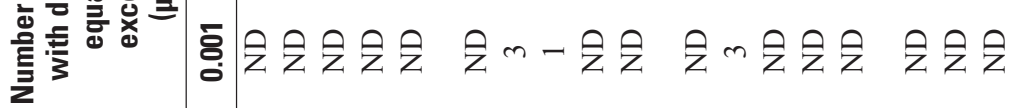

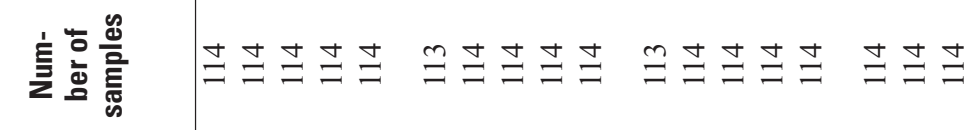
호ㄷㅗㅗㄹ

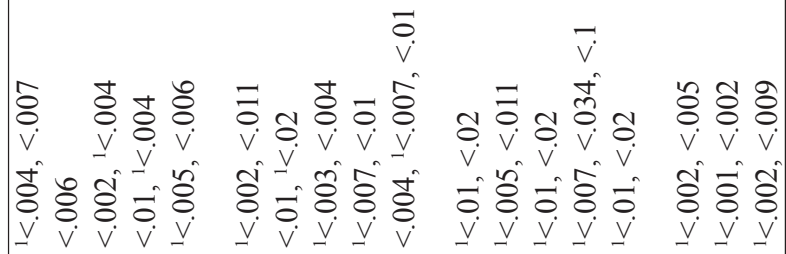

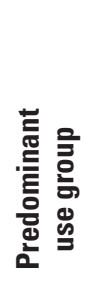

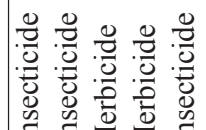

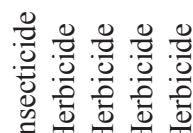

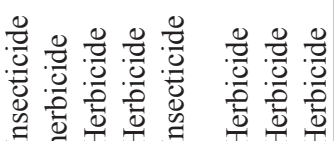

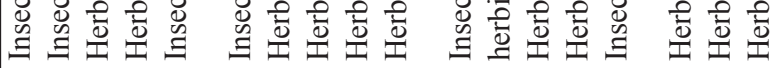

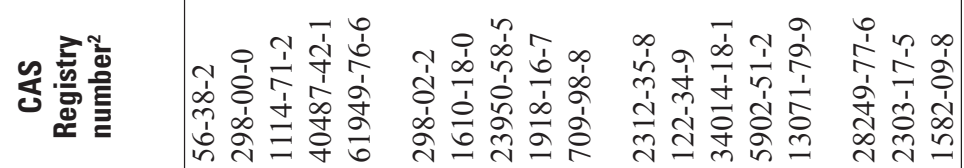
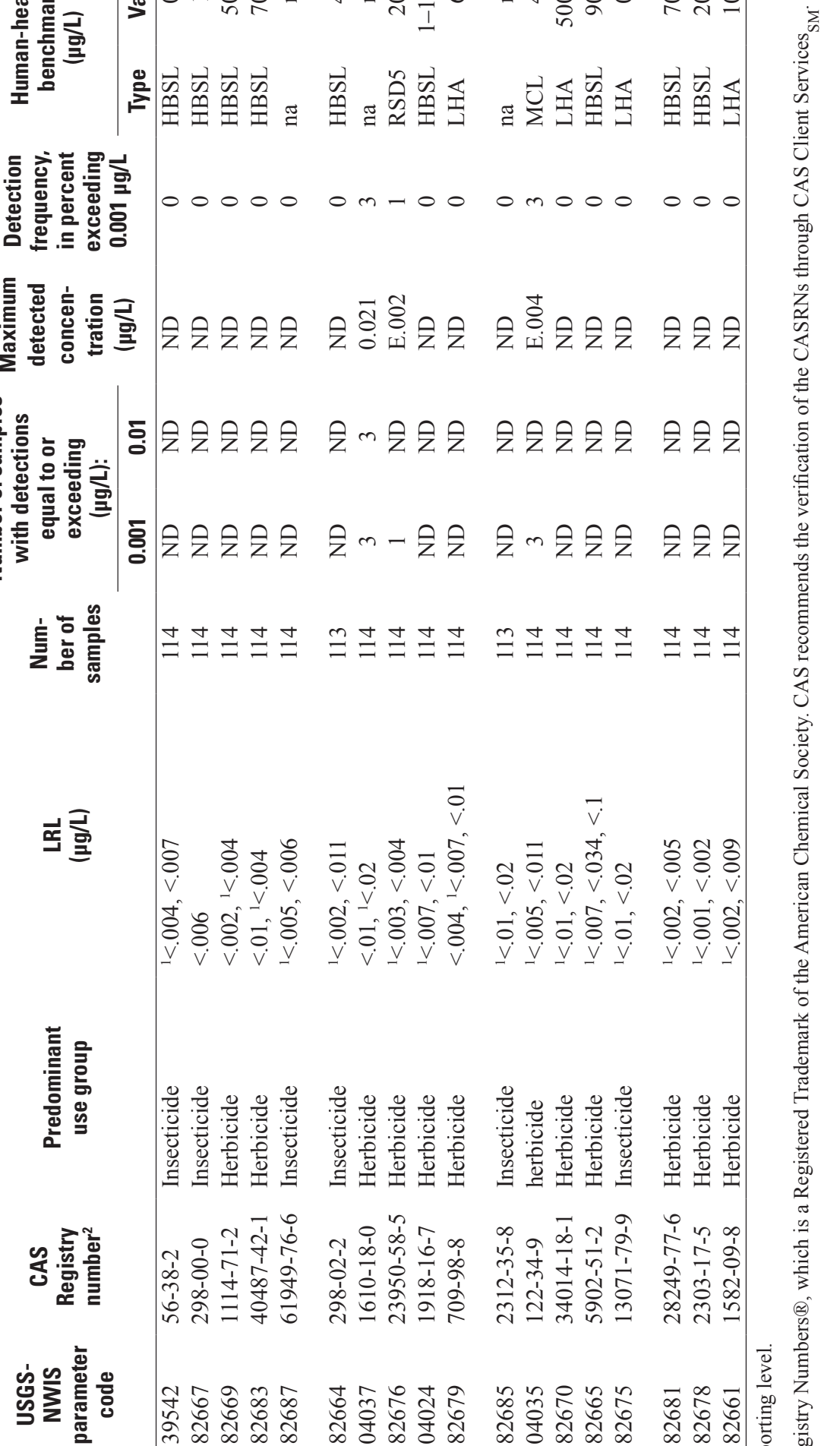

$\overline{\mathscr{c}}$
.00
$\frac{0}{8}$
0
0

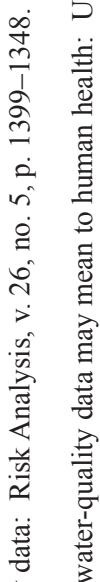

焉

要色

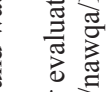

党总

$\sum^{2}$ 

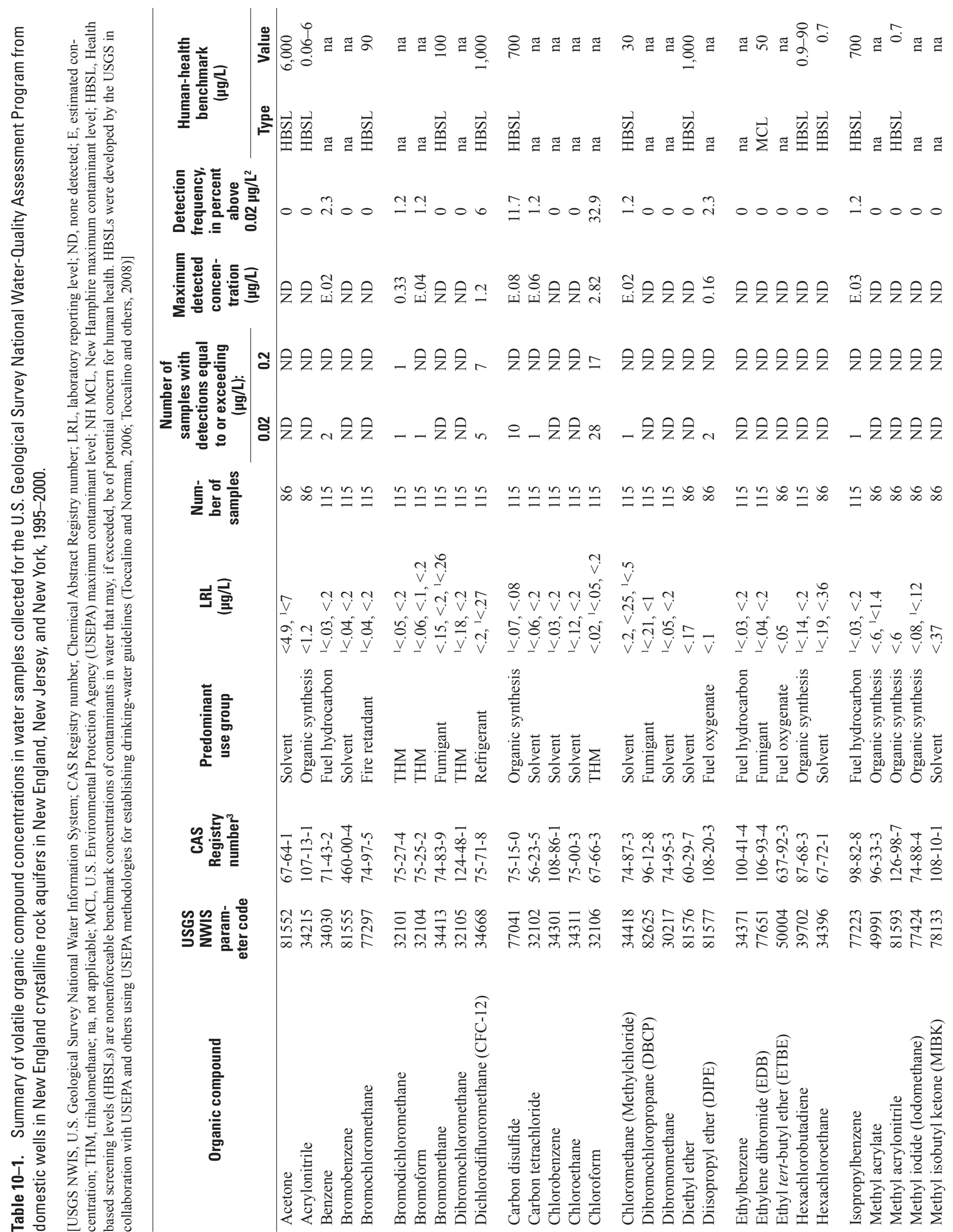

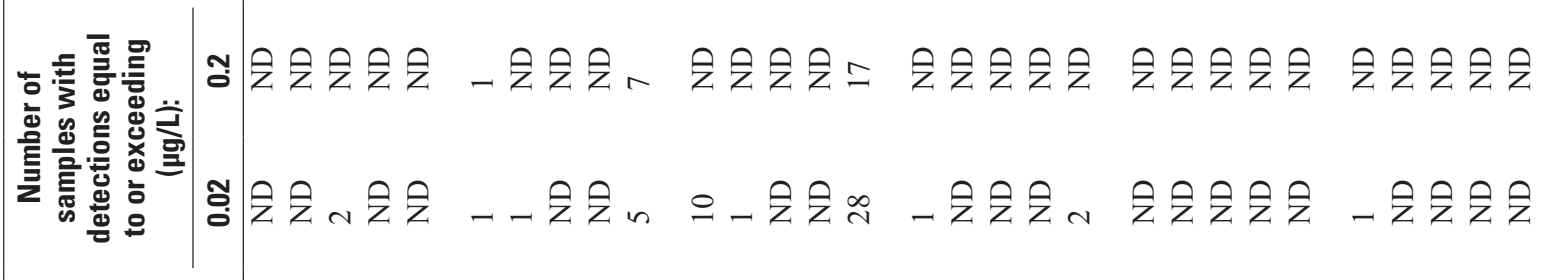
重䇏离

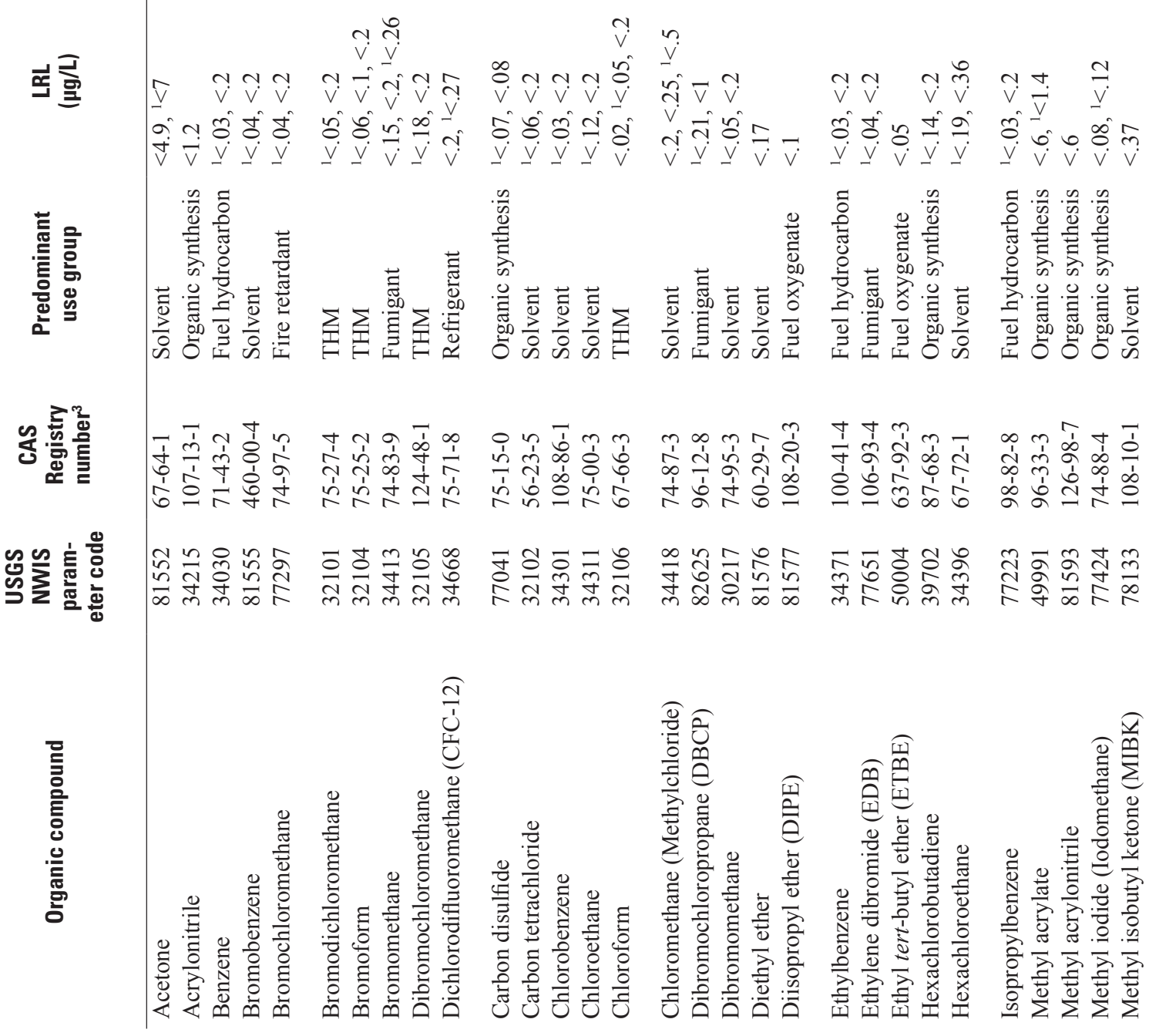




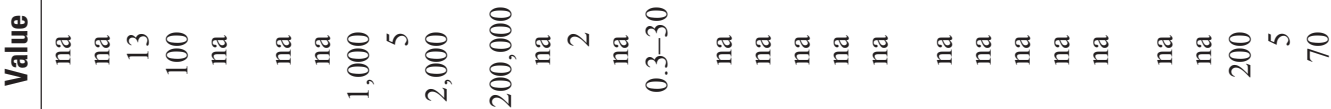

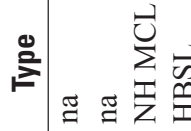

I 0

造 흠

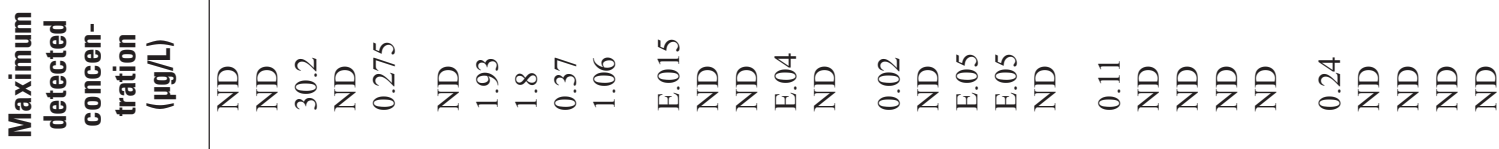

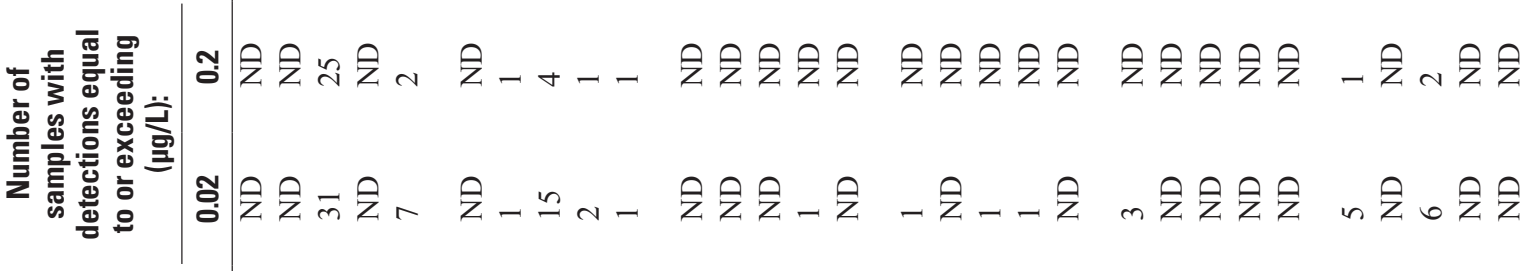
范

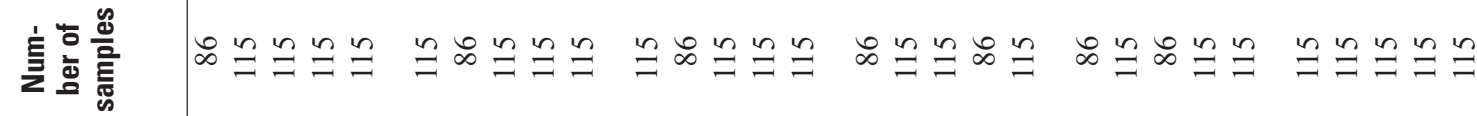

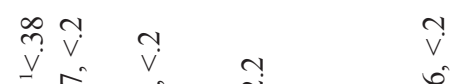
ปี

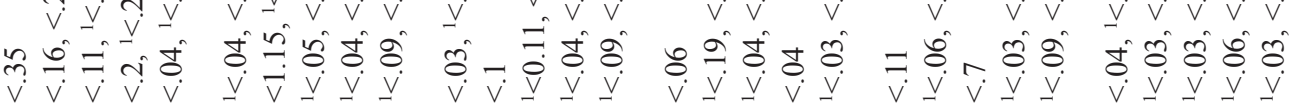



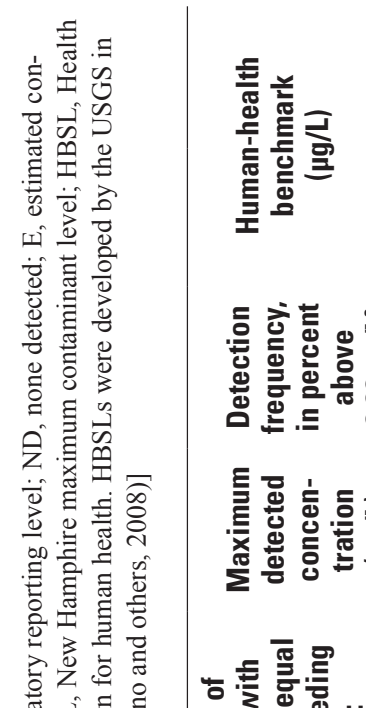

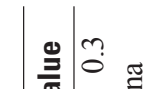

政

仓े

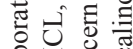

- 80

정

空沓官

iิ

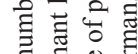

d

نे

要

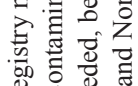

흔흔

ग्ञ

言

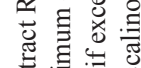

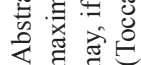

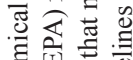

可

\&

过

言总空

氙 .

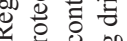

पर

语产高

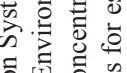

产

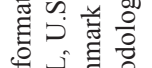

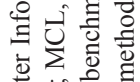

要过

创 可氜 矛

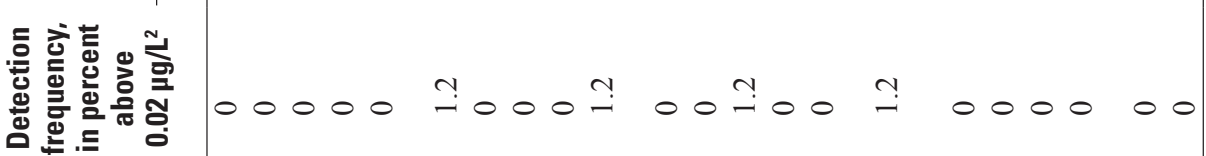

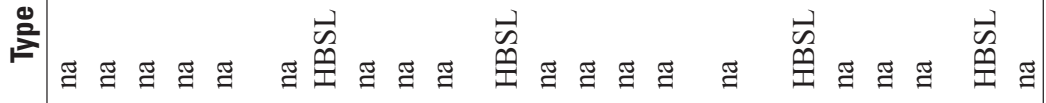

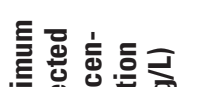

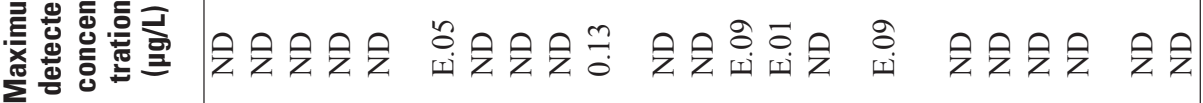

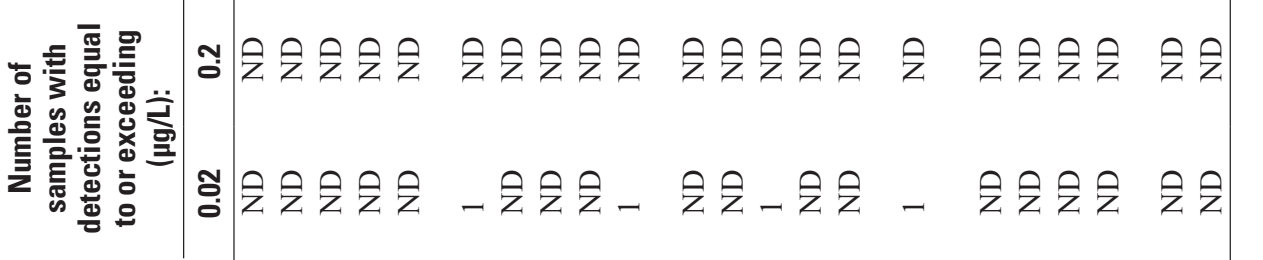

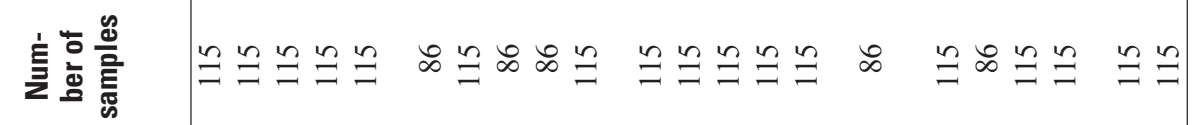

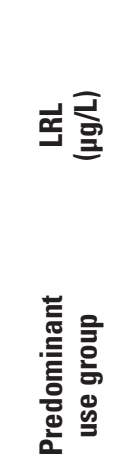

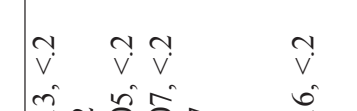

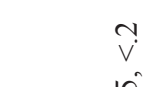

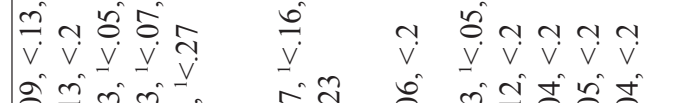

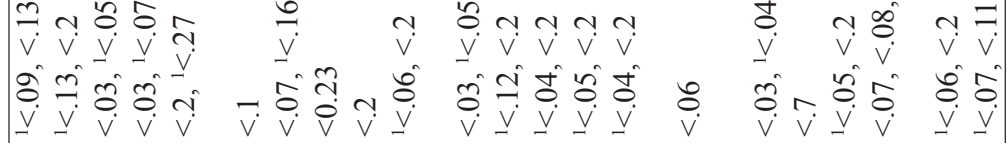

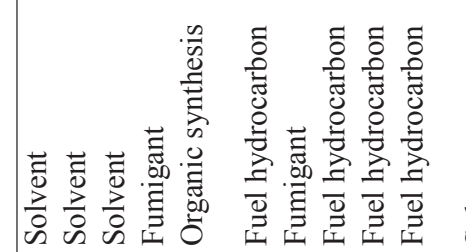

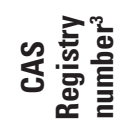

in

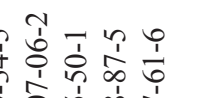

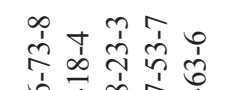

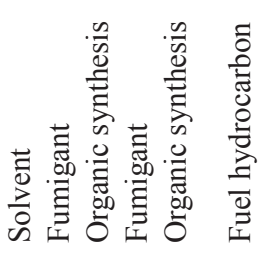

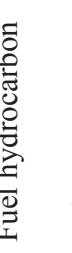

.

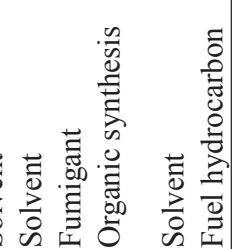

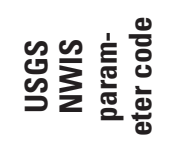

रें

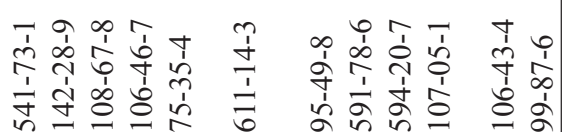

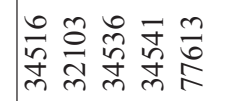

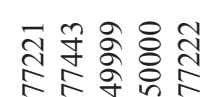

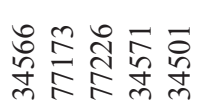

$\stackrel{\text { त }}{\approx}$

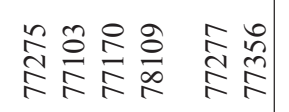

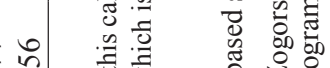

을
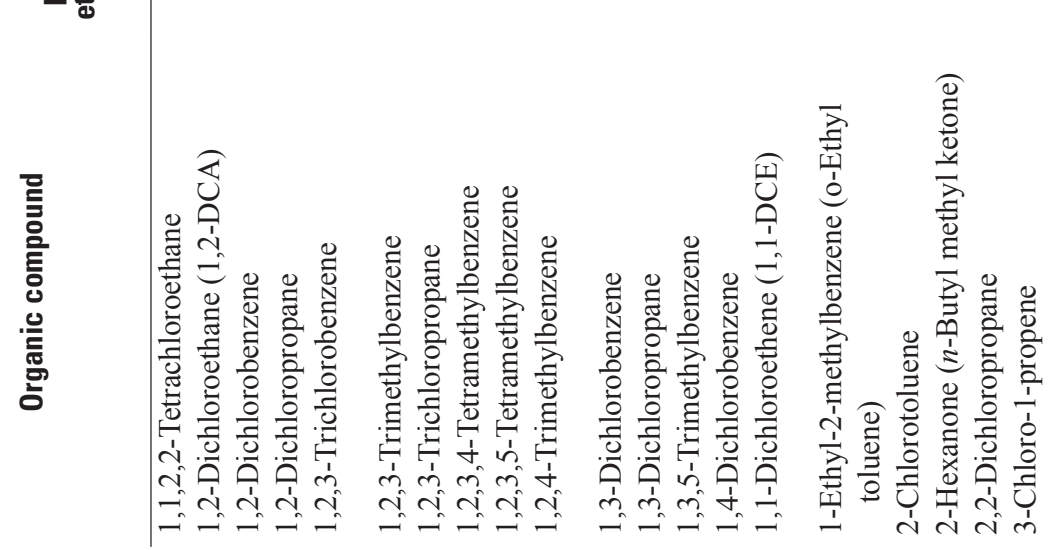

$\therefore r$

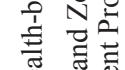

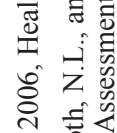

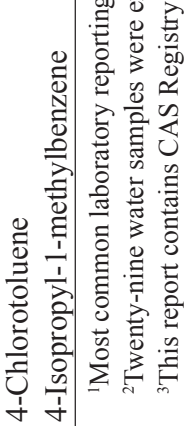

ํㅓㄹ 至

สี

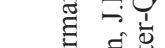

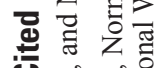

बैं

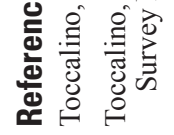


Table 11-1. Rho and probability values from Spearman correlations of selected water-quality properties and constituents, land-use and human population data, and well construction properties with chloroform and methyl tert-butyl ether concentrations in water samples collected from domestic and public-supply wells in New England crystalline rock aquifers, 1995-2007.

[Spearman's coefficients (rho) are considered significant (in bold) when the $P$-values are less than or equal to 0.05; a negative rho value indicates an inverse relation. Rho, Spearman's rho coefficient; $P$-value, Spearman's probability value; MtBE, methyl tert-butyl ether; N, number of samples; <, less than; X, no data; $\mathrm{km}^{2}$, square kilometer; USGS NAWQA, domestic bedrock wells sampled for the U.S. Geological Survey National Water-Quality Assessment Program in New England, New Jersey, and New York; USEPA SDWA, public-supply bedrock wells sampled for the U.S. Environmental Protection Agency Safe Drinking Water Act Program in New England]

\begin{tabular}{|c|c|c|c|c|c|}
\hline \multirow[b]{2}{*}{ Factor definition } & \multirow{2}{*}{$\begin{array}{c}\text { Spearman's } \\
\text { correlation } \\
\text { variables }\end{array}$} & \multirow{2}{*}{$\begin{array}{c}\text { Chloroform } \\
\text { USGS NAWOA }\end{array}$} & \multicolumn{3}{|c|}{ Methyl tert-butyl ether } \\
\hline & & & USGS NAWQA & USEPA SDWA & $\begin{array}{l}\text { All wells } \\
\text { in study }\end{array}$ \\
\hline \multicolumn{6}{|c|}{ Physiochemical properties and water-quality constituents determined from water samples } \\
\hline \multirow[t]{3}{*}{ Bicarbonate } & Rho & -0.27 & 0.107 & $\mathrm{X}$ & 0.107 \\
\hline & $P$-value & 0.0030 & 0.0100 & $\mathrm{X}$ & 0.0100 \\
\hline & $\mathrm{N}$ & 114 & 114 & $\mathrm{X}$ & 114 \\
\hline \multirow[t]{3}{*}{ Calcium } & Rho & 0.060 & 0.429 & $\mathrm{X}$ & 0.429 \\
\hline & $P$-value & 0.5166 & $<.0001$ & $\mathrm{X}$ & $<.0001$ \\
\hline & $\mathrm{N}$ & 115 & 115 & $\mathrm{X}$ & 115 \\
\hline \multirow[t]{3}{*}{ Chloride } & Rho & 0.29 & 0.419 & 0.265 & 0.257 \\
\hline & $P$-value & 0.0020 & $<.0001$ & $<0.0001$ & $<0.0001$ \\
\hline & $\mathrm{N}$ & 115 & 115 & 476 & 591 \\
\hline \multirow[t]{3}{*}{ Chloroform } & Rho & 1 & 0.364 & $\mathrm{X}$ & 0.236 \\
\hline & $P$-value & -- & $<.0001$ & $\mathrm{X}$ & 0.0112 \\
\hline & $\mathrm{N}$ & 115 & 115 & $\mathrm{X}$ & 115 \\
\hline \multirow[t]{3}{*}{ Dissolved oxgyen } & Rho & 0.345 & 0.166 & $\mathrm{X}$ & 0.246 \\
\hline & $P$-value & 0.0002 & 0.0782 & $\mathrm{X}$ & 0.0086 \\
\hline & $\mathrm{N}$ & 113 & 113 & $\mathrm{X}$ & 113 \\
\hline \multirow[t]{3}{*}{ Iron, total } & Rho & -0.2 & -0.209 & 0.193 & 0.150 \\
\hline & $P$-value & 0.0299 & 0.0250 & $<0.0001$ & $<0.0001$ \\
\hline & $\mathrm{N}$ & 115 & 115 & 576 & 691 \\
\hline \multirow[t]{3}{*}{ Manganese } & Rho & 0.15 & -0.14 & 0.223 & 0.183 \\
\hline & $P$-value & 0.1088 & 0.1355 & $<0.0001$ & $<0.0001$ \\
\hline & $\mathrm{N}$ & 115 & 115 & 623 & 738 \\
\hline \multirow[t]{3}{*}{$\mathrm{MtBE}$} & Rho & 0.364 & 1 & 1 & 1 \\
\hline & $P$-value & $<.0001$ & -- & -- & -- \\
\hline & $\mathrm{N}$ & 115 & 115 & 1,184 & 1,299 \\
\hline \multirow[t]{3}{*}{ Nitrate } & Rho & 0.525 & 0.488 & 0.001 & 0.024 \\
\hline & $P$-value & $<.0001$ & $<.0001$ & 0.97 & 0.4013 \\
\hline & $\mathrm{N}$ & 115 & 115 & 1,131 & 1,246 \\
\hline \multirow[t]{3}{*}{$\mathrm{pH}$} & Rho & -0.42 & -0.261 & -0.07 & -0.092 \\
\hline & $P$-value & $<.0001$ & 0.0048 & 0.153 & 0.033 \\
\hline & $\mathrm{N}$ & 115 & 115 & 422 & 537 \\
\hline \multirow[t]{3}{*}{ Specific conductance } & Rho & 0.061 & 0.370 & 0.323 & 0.315 \\
\hline & $P$-value & 0.5144 & $<.0001$ & $<.0001$ & $<0.0001$ \\
\hline & $\mathrm{N}$ & 115 & 115 & 172 & 287 \\
\hline
\end{tabular}


Table 11-1. Rho and probability values from Spearman correlations of selected water-quality properties and constituents, land-use and human population data, and well construction properties with chloroform and methyl tert-butyl ether concentrations in water samples collected from domestic and public-supply wells in New England crystalline rock aquifers, 1995-2007.-Continued

[Spearman's coefficients (rho) are considered significant (in bold) when the $P$-values are less than or equal to 0.05 ; a negative rho value indicates an inverse relation. Rho, Spearman's rho coefficient; $P$-value, Spearman's probability value; M $t \mathrm{BE}$, methyl tert-butyl ether; N, number of samples; <, less than; X, no data; $\mathrm{km}^{2}$, square kilometer; USGS NAWQA, domestic bedrock wells sampled for the U.S. Geological Survey National Water-Quality Assessment Program in New England, New Jersey, and New York; USEPA SDWA, public-supply bedrock wells sampled for the U.S. Environmental Protection Agency Safe Drinking Water Act Program in New England]

\begin{tabular}{|c|c|c|c|c|c|}
\hline \multirow[b]{2}{*}{ Factor definition } & \multirow{2}{*}{$\begin{array}{c}\text { Spearman's } \\
\text { correlation } \\
\text { variables }\end{array}$} & \multirow{2}{*}{$\begin{array}{c}\text { Chloroform } \\
\text { USGS NAWOA }\end{array}$} & \multicolumn{3}{|c|}{ Methyl tert-butyl ether } \\
\hline & & & USGS NAWOA & USEPA SDWA & $\begin{array}{l}\text { All wells } \\
\text { in study }\end{array}$ \\
\hline \multicolumn{6}{|c|}{ Physiochemical properties and water-quality constituents determined from water samples-Continued } \\
\hline \multirow[t]{3}{*}{ Sodium } & Rho & -.005 & 0.221 & 0.166 & 0.153 \\
\hline & $P$-value & 0.9508 & 0.0177 & $<0.0001$ & $<0.0001$ \\
\hline & $\mathrm{N}$ & 115 & 115 & 819 & 934 \\
\hline \multirow[t]{3}{*}{ Sulfate } & Rho & 0.13 & 0.357 & $X$ & 0.357 \\
\hline & $P$-value & 0.1582 & 0.0001 & $\mathrm{X}$ & 0.0001 \\
\hline & $\mathrm{N}$ & 115 & 115 & $X$ & 115 \\
\hline \multirow[t]{3}{*}{ Total dissolved solids } & Rho & 0.122 & 0.397 & $X$ & 0.397 \\
\hline & $P$-value & 0.1956 & $<.0001$ & $\mathrm{X}$ & $<.0001$ \\
\hline & $\mathrm{N}$ & 115 & 115 & $X$ & 115 \\
\hline \multirow[t]{3}{*}{ Apparent residence time of water } & Rho & 0.067 & -0.29 & $X$ & -0.29 \\
\hline & $P$-value & 0.6318 & 0.0365 & $X$ & 0.0365 \\
\hline & $\mathrm{N}$ & 54 & 54 & $\mathrm{X}$ & 54 \\
\hline \multicolumn{6}{|c|}{ Land use and population density within 500-meter radius of sampled wells } \\
\hline \multirow[t]{3}{*}{ Percent agricultural lands } & Rho & -0.308 & -0.104 & -0.059 & -0.055 \\
\hline & $P$-value & 0.0008 & 0.2695 & 0.0429 & 0.0495 \\
\hline & $\mathrm{N}$ & 115 & 115 & 1,184 & 1,299 \\
\hline \multirow[t]{3}{*}{ Percent developed lands } & Rho & 0.247 & 0.259 & 0.160 & 0.155 \\
\hline & $P$-value & 0.0078 & 0.0051 & $<0.0001$ & $<0.0001$ \\
\hline & $\mathrm{N}$ & 115 & 115 & 1,184 & 1,299 \\
\hline \multirow[t]{3}{*}{ Percent undeveloped lands } & Rho & -0.12 & -0.211 & -0.074 & -0.079 \\
\hline & $P$-value & 0.2030 & 0.0235 & 0.011 & 0.0044 \\
\hline & $\mathrm{N}$ & 115 & 115 & 1,184 & 1,299 \\
\hline \multirow[t]{3}{*}{ Population density, in persons $/ \mathrm{km}^{2}$} & Rho & 0.406 & 0.242 & 0.197 & 0.187 \\
\hline & $P$-value & $<.0001$ & 0.0093 & $<0.0001$ & $<0.0001$ \\
\hline & $\mathrm{N}$ & 115 & 115 & 1,184 & 1,299 \\
\hline \multirow{4}{*}{ Well depth, in $\mathrm{ft}$} & & construction pro & rties & & \\
\hline & Rho & -0.24 & 0.023 & 0.038 & 0.05 \\
\hline & $P$-value & 0.0100 & 0.8108 & 0.38 & 0.2023 \\
\hline & $\mathrm{N}$ & 115 & 115 & 548 & 663 \\
\hline \multirow[t]{3}{*}{ Water level, in $\mathrm{ft}$} & Rho & 0.185 & 0.156 & $\mathrm{X}$ & 0.156 \\
\hline & $P$-value & 0.0636 & 0.1193 & $\mathrm{X}$ & 0.1193 \\
\hline & $\mathrm{N}$ & 101 & 101 & $\mathrm{X}$ & 101 \\
\hline \multirow[t]{3}{*}{ Casing length, in $\mathrm{ft}$} & Rho & 0.153 & -0.067 & -0.023 & -0.009 \\
\hline & $P$-value & 0.1035 & 0.4811 & 0.727 & 0.8615 \\
\hline & $\mathrm{N}$ & 114 & 114 & 234 & 348 \\
\hline
\end{tabular}


Prepared by the Pembroke and West Trenton Publishing Service Centers.

For more information concerning this report, contact:

Director

U.S. Geological Survey

New Hampshire-Vermont Water Science Center

331 Commerce Way, Suite 2

Pembroke, NH 03275

dc_nh@usgs.gov

or visit our Web site at:

http://nh.water.usgs.gov 


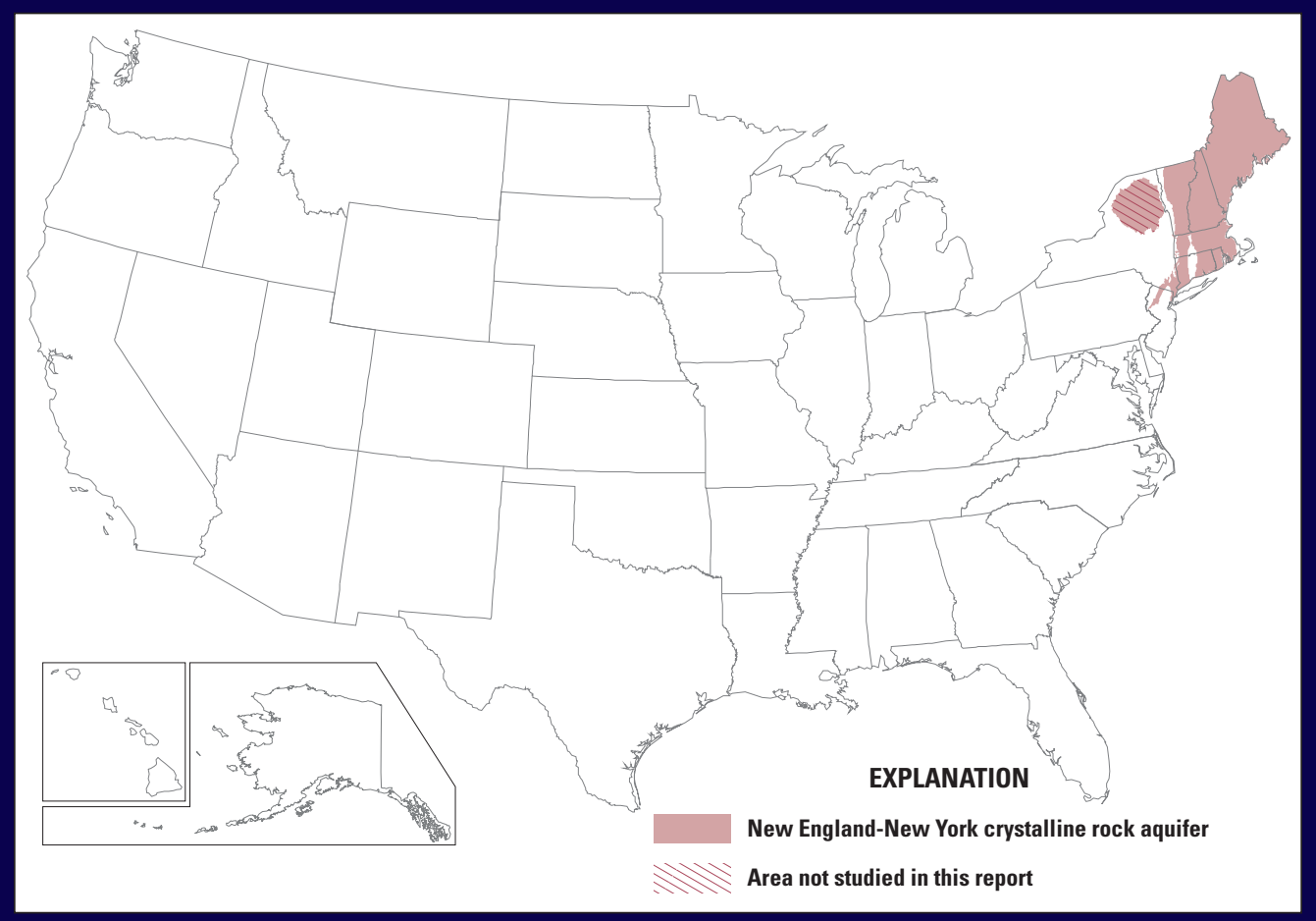

